\title{
POTENCIALIDADE DE ESPÉCIES DE Eucalyptus PARA PRODUÇÃO DE MADEIRA SERRADA
}

\author{
VITOR GONZAGA BARCHET \\ Engenheiro Florestal
}

\section{Orientador: Prof. Dr. JOSÉ NIVALDO GARCIA}

Dissertação apresentada à Escola Superiôr de Agricultura "Luiz de Queiroz", Universidade de São Paulo, para obtenção do título de Mestre em

Ciências, Área de Concentração: Ciência e Tecnologia de Madeiras.

PIRACICABA

Estado de são Paulo - Brasil

Dezembro de 2001 
Barchet, Vitor Gonzaga

Potencialidade de espécies de Eucalyptus para produção de madeira serrada / Vitor Gonzaga Barchet. - - Piracicaba, 2001. $166 \mathrm{p}$.

Dissertação (mestrado) - - Escola Superior de Agricultura Luiz de Queiroz, 2001. Bibliografia.

1. Eucalyptus 2. Madeira (Qualidade) 3. Serrarias 1. Título 
A globalização da economia é um grande empreendimento humano, hegemônico, do qual o homem sentirá orgulho, semelhante ao do "Titanic", que em sua primeira viagem, deixou a verdade à tona.

O ser humano nasceu para a solidariedade e não para a competitividade.

Não é oprimindo povos, que se constróem monumentos.

Quando a ciência não está a serviço da humanidade, por mais magnifica que seja, ela é inútil, fútil e vazia. De qualquer maneira ela não deverá jamais suplantará a ética, a moral e o humilde temor a Deus.

Deus é o dono absoluto, do dia, da noite, do visível, do invisível, do nosso consciente, do subconsciente, do inconsciente, do conhecido, do desconhecido e do oculto. "Ele" sabe e vê tudo.

A ciência está evoluindo tanto, que logo estar-se-á na idade da pedra. 
À Deus Uno e Trino,
Criador do universo, fonte de todo o bem e poder.
Sem "Ele" nada subsiste,

e

À Santa Maria, Mãe de Deus, Imaculada e Intercessora nossa, por tudo que me tem provido e por amparar-me num grave acidente, OFEREÇO.

Aos meus pais:

Victor Antenor Barchet; Carmelinda Rossato Barchet;

E aos meus irmãos, João Luiz José Aloísio Sérgio Francisco Izabel Cristina Clóvis Roberto e Meu Filho, Victor Barchet.

DEDICO. 


\section{AGRADECIMENTOS}

Ao programa PICDT/CAPES, ACAFE-SC, pela valiosa concessão da Bolsa de Mestrado.

Ao Amigo Prof. Ms. Luiz Eduardo Gelynský Júnior, UNOESC, Videira-SC por inúmeros favores prestados.

Ao Prof. Dr. José Nivaldo Garcia, pela valiosa orientação, correções, amizade, apoio e incentivos que permitiram a realização deste trabalho.

Ao Prof. Dr. Nilson Franco e Prof. Dr. Mário Ferreira pelas valiosas correções e sugestões no presente trabalho.

Ao Prof. Dr. Marcio Augusto Rabello Nahuz e pesquizadores do IPT - Divisão madeiras, pela oportunidade de estágio e treinamento.

Ao Eng. Gilson Roberto Vasconcelos dos Santos, pelas valiosas sugestões e pelo grande auxílio prestados na coleta dos dados.

Ao Eng. Vitor Augusto Graner Fessel, pela elaboração da programação do SAS, que permitiram a análise estatística dos dados.

Ao Prof. Ivaldo Pontes Jankowsky, pelos ensinamentos, auxilio e amizade.

Ao Prof. Marcelo Corrêa Alves, pelas orientações e ensinamentos na programação do SAS e interpretação do mesmo.

Ao Desenhista Mauro Sérgio Campello da Silva, pela confecção dos desenhos no AutoCAD.

A todos os professores do Departamento de Ciências Florestais e Tecnologia da Madeira da ESALQ-USP, pelos valiosos ensinamentos e orientações recebidas.

Ao técnico Carlos Eduardo da Costa Maria, Engo. Rildo Moreira e Moreira e demais funcionários e empreiteiros da Estação Experimental de Anhembi, pela valiosa contribuição nas atividades de campo.

Ao Setor de Transportes da ESALQ, que facilitaram no transporte da madeira de Anhembi até a serraria da ESALQ em Piracicaba.

Ao Prof. Dr. Fernando Seixas, por ceder a madeira da Estação Experimental de Anhembi, para o presente trabalho.

Ao Engenheiro Israel Gomes Vieira do setor de sementes do IPEF, por ceder material de consulta, e inúmeros auxílios de campo.

Ao setor de Carpintaria da ESALQ, Piracicaba: Sr. Lazaro (Liu), Wilson Zane, Sidnei (Cide), Natal, Sr. Luiz Renosto (Palhinha), Agnaldo (Sócrates), Carlitos (BiroBiro), por inúmeros serviços prestados e desdobro da madeira.

Aos amigos; Eng ${ }^{\circ}$. Luiz Carlos Farias, Eng ${ }^{\circ}$. Adalberto Fujihara (Tora), Eng ${ }^{\circ}$. Denis Cesar Cararo, pela amizade e valiosos auxílios prestados, no entendimento do sistema operacional do Excel, Powerpoint e no Word.

À Bibliotecária Eliana Maria Garcia por inúmeras correções na Dissertação e ao assistente técnico de documentação Paulo S. Baraldo pelas imprescindíveis correções feitas na citação bibliográfica. 
Ao estudante de graduação de Engenharia florestal Flavio Levin Cremonezi, pelos trabalhos fotográficos.

Aos amigos, Eng ${ }^{\circ}$. Israel Luiz de Lima, Eng ${ }^{\circ}$. Luciano (Bahia), Eng ${ }^{\circ}$. Maurício S. Sartori, Eng $^{\circ}$. Marcelino C. Guedes, Eng'. Sônia Carpinelli, Eng ${ }^{\circ}$. Márcio Fedelle, Eng ${ }^{\circ}$. Lothar Schacht, pela amizade, companheirismo estímulo desenvolvida durante o curso.

Ao Ivo Rosa Filho, por inúmeros auxílios prestados na informática.

Ao $\mathrm{Eng}^{\circ}$. Ariel de Andrade e $\mathrm{Eng}^{\circ}$. Jacson Roberto Eleotério, pelo auxílio prestadas durante as disciplinas do curso.

Ao Eng ${ }^{\circ}$. Paulo Eduardo Telles dos Santos, por sujestões e correções prestadas.

A Eng ${ }^{\circ}$. Anna C. Pacheco Abdalla pelas correções no AutoCAD.

Aos colegas, Eng ${ }^{\circ}$. Rodrigo A. Rodrigues, Eng ${ }^{\circ}$. Alexandre Carvalho, Eng ${ }^{\circ}$ Laerte Scanavaca Junior, Eng "Erica A. Crespo, Eng'. Maria de Fátima Christe Adomo, Eng". Eliane R. Eleotério, Enga. Patrícia S. Azevedo, Suzan Valéria dos Santos, Enga. Ana Lira, pela convivência amiga durante o curso.

Ao Rodrigo Sbravatti, estudante da graduação pelo feliz engano das solicitações de transporte de madeiras.

Aos Funcionários da ESALQ-USP, Rogério, Luis Eduardo Facco, Edmilson, Jeferson, Regina, Sérgio, Margareth, Marialice Poggiani, Thais, Maria pela convivência fratema durante 0 curso e inúmeros auxílios e favores prestados.

A todos os colegas da graduação da casa de estudante

Airbag, Arribada, Azulão, Beato, Discarado, Doberman, Tonel, Dogine (Ursinho), Don Juan, Fuca, Genérico, Girafales, Janjão, Malária, Mandaí, Moca, Nervo, Peteí, Pequeno, Xapolim e a Dona Iolanda, pela convivência amiga e favores concedidos no Mestrado.

À todos

Sinceros agradecimentos. 


\section{SUMÁRIO}

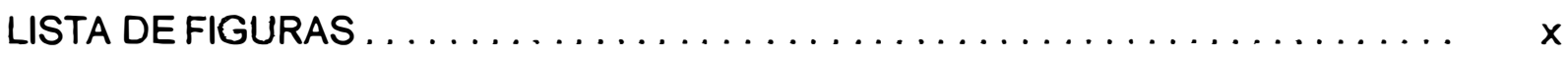

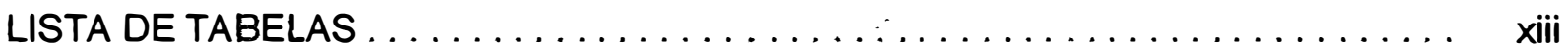

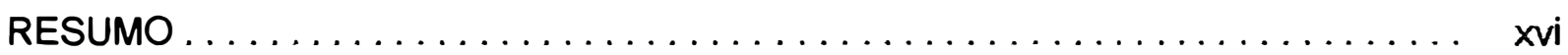

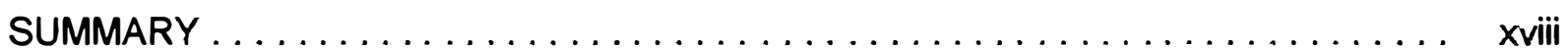

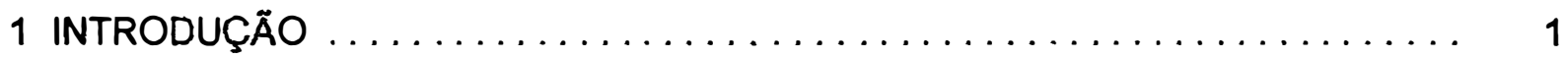

2 REVISÄO DE LITERATURA $\ldots \ldots \ldots \ldots \ldots \ldots \ldots \ldots \ldots \ldots \ldots \ldots$

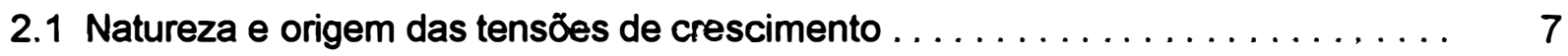

2.1.1 Organização da parede celular . . . . . . . . . . . . . . . . . . 10

2.1.2 Madeira de reação ocasionada pelas tensões de crescimento . . . . . . . . . . 12

2.1.3 Fatores externos que influenciam as tensões de crescimento . . . . . . . . . 15

2.1.4 Variaçăo das tensões de crescimento no tronco . . . . . . . . . . . . 16

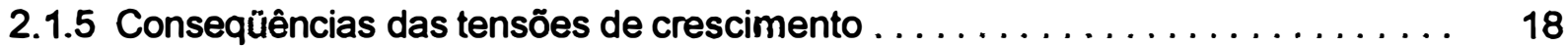

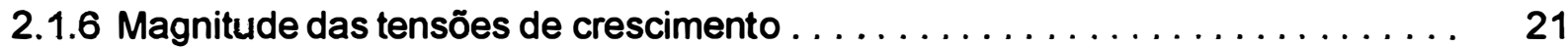

2.1.7 Procedimentos para reduzir os efeitos oriundos das tensões de crescimento 22

2.2 Sistema de desdobro . . . . . . . . . . . . . . . . . . . . . . . . . 26

2.3 Rendimentos no desdobro . . . . . . . . . . . . . . . . . . 31

2.4 Percentagem de alburno. . . . . . . . . . . . . . . . . . . . . 32

2.5 Quantidade de casca. . . . . . . . . . . . . . . . . . . . . . 35

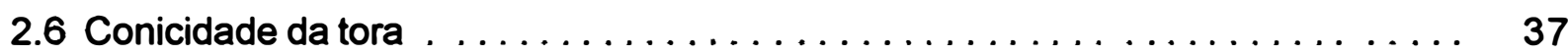

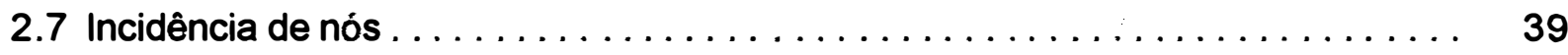

2.8 Rachaduras . . . . . . . . . . . . . . . . . . . . . . 42

2.9 Encurvamentos (Flecha) . . . . . . . . . . . . . . . . . . . . . 44

2.10 Dureza (Janka) . . . . . . . . . . . . . . . . . . . . . 45

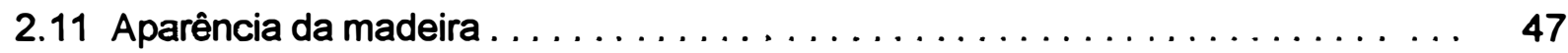

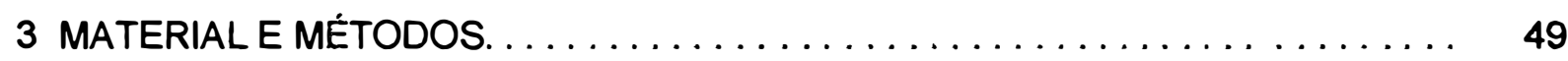




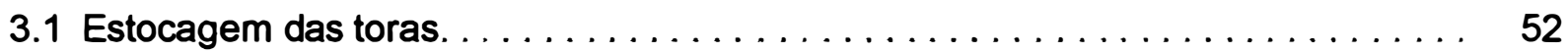

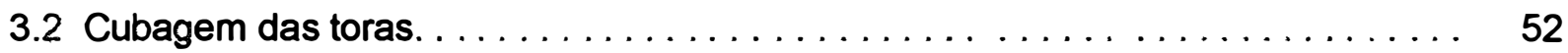

3.3 Quantificação da casca. ............................ 52

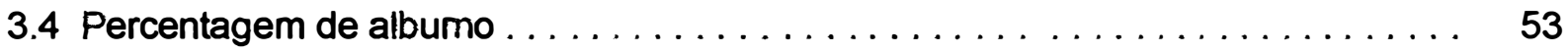

3.5 Conicidade. .................................... 53

3.6 Desdobro .................................. 54

3.7 Quantidade dos nós . . . . . . . . . . . . . . . . . . . . . . . . 56

3.8 Rachaduras de extremidades das peças serradas ................ 56

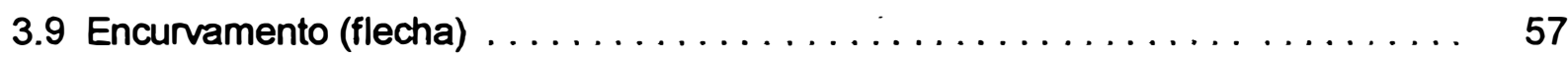

3.10 Rendimento de madeira serrada $(\mathrm{RMS}) \ldots \ldots \ldots \ldots \ldots \ldots \ldots \ldots \ldots$

3.11 Estocagem da madeira serrada $\ldots \ldots \ldots \ldots \ldots \ldots \ldots \ldots \ldots \ldots \ldots \ldots$

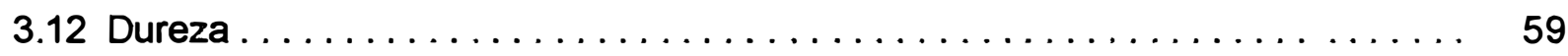

3.13 Delineamento estatístico. ............................. 60

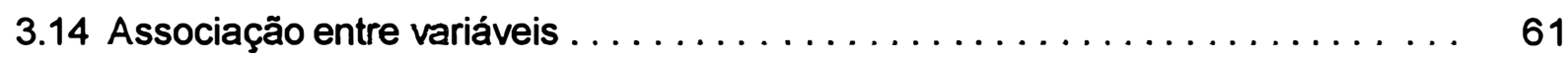

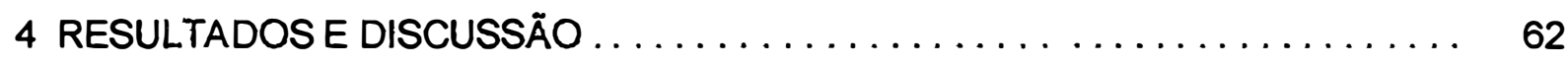

4.1 Variação do diâmetro e altura das espécies de Eucalyptus . . . . . . . . . . . 62

4.2 Percentagem de alburno. . . . . . . . . . . . . . . . . . . . . 67

4.3 Percentagem de casca. . . . . . . . . . . . . . . . . . . . . . . . 72

4.4 Conicidade das toras. $\ldots \ldots \ldots \ldots \ldots \ldots \ldots \ldots \ldots \ldots \ldots \ldots \ldots . \ldots \ldots$

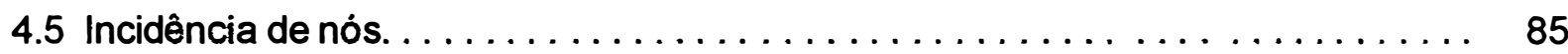

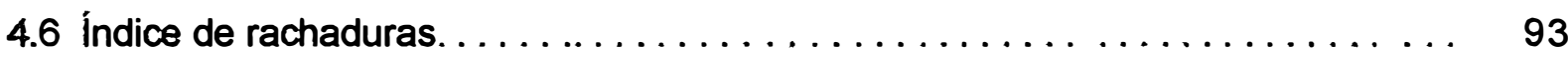

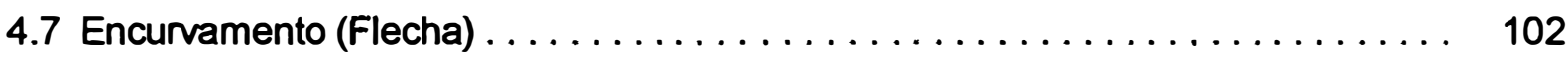

4.8 Rendimento de madeira serrada $(\mathrm{RMS}) \ldots \ldots \ldots \ldots \ldots \ldots \ldots \ldots \ldots \ldots . \ldots \ldots$

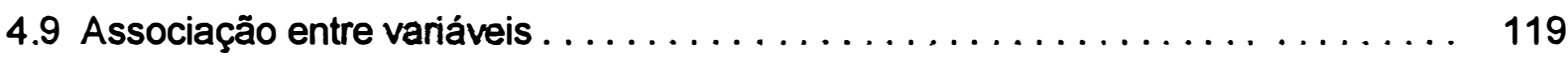

4.9.1 Rendimento em madeira serrada (RMS) e diâmetro ............... 121

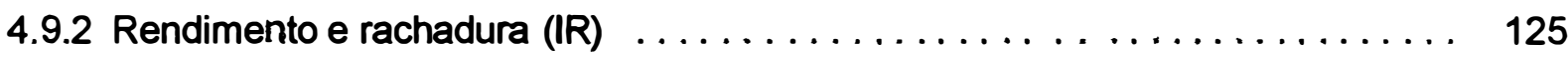

4.9.3 Rendimento em madeira serrada (RMS) e conicidade . ............... 127

4.9.4 Rendimento e encurvamento . . . . . . . . . . . . . . . . . . . 130

4.9 .5 Encurvamento e índice de rachadura $I R \ldots \ldots \ldots \ldots \ldots \ldots \ldots \ldots \ldots . \ldots \ldots$

4.9.6 Índice de rachadura de extremidade da tábua e diâmetro . . . . . . . . . . 134

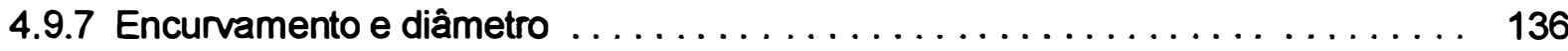

4.10 Dureza da madeira ................................ 138 
4.11 Aparência da madeira $\ldots \ldots \ldots \ldots \ldots \ldots \ldots \ldots \ldots \ldots \ldots \ldots \ldots \ldots \ldots$

4.12 Comparação das espécies . . . . . . . . . . . . . . . . . . . . . . . . . . 144

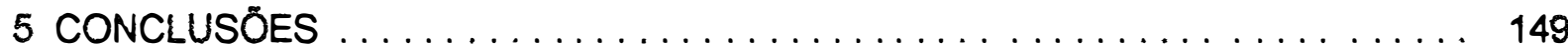

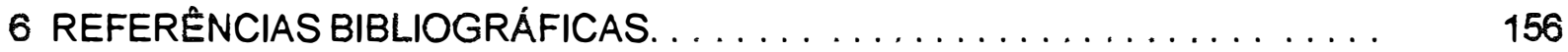




\section{LISTA DE FIGURAS}

1 Distribuição das tensões residuais nos troncos que contém lenho de reação . . . .

2 Distribuição das tensōes residuais longitudinais, antes e após o tratamento

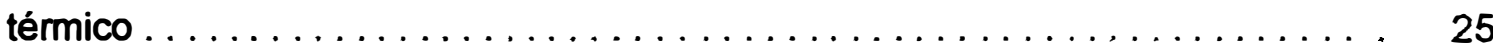

3 Esquema de anelamento e seccionamento do fuste. . . . . . . . . . . . . . 51

4 Sistema de desdobro por cortes tangenciais semi-balanceados . . . . . . . . . . 54

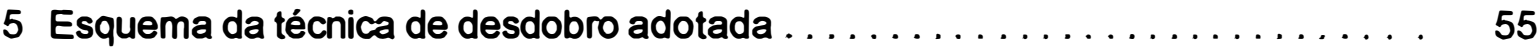

6 Rachadura de extremidade de tábua . . . . . . . . . . . . . . . . . . . . . 57

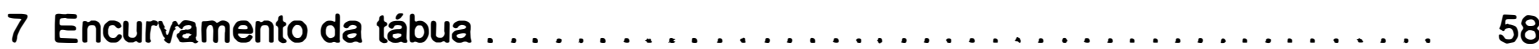

8 Relação entre altura comercial média e o DAP médio das árvores, de Eucalyptus 64

9 Diâmetros médios das toras das 15 espécies de Eucalyptus, agrupadas por

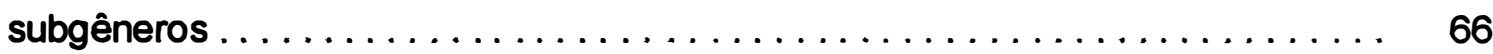

10 Percentagem de albumo das 15 espécies de Eucalyptus . . . . . . . . . 68

11 Espessura do albumo, em relação ao diâmetro da tora . . . . . . . . . . . . 70

12 Variação da percentagem de alburno no fuste, de Eucalyptus . . . . . . . . . 71

13 Percentagem média de casca das 15 espécies de Eucalyptus. . . . . . . . . . . 75

14 Espessura da casca na tora da base (tora A) e na subsequente (tora B). . . . . 76

15 Percentagem de casca na tora da base (tora A) e na subsequente (tora $B$ ) . . . 77

16 Tipos de casca das espécies dos subgêneros Symphyomyrtus e ldiogenes. . . . 78

17 Tipos de casca das espécies dos subgêneros Monocalyptus e Corymbia. . . . . . 79

18 Distribuição da conicidade média nas 15 espécies de Eucalyptus. . . . . . . . . . 84

19 Conicidade média de tora sem casca das 15 espécies de Eucalyptus. . . . . . 84

20 Percentagem média de tábuas sem nós. . . . . . . . . . . . . . . . . . 89

21 Incidência média de nós por face de tábua, nas 15 espécies de Eucalyptus . . . 89

22 Incidência média de nós por face de tábuas na tora da base (tora $A$ ) e na tora subsequente (tora $B)$, nas 15 espécies de Eucalyptus . . . . . . . . . . . . 90 
23 Distribuição da freqüência média de nós por face, no sentido casca medula casca . . . . . . . . . . . . . . . . . . . . . . . . . . 91

24 indice médio de rachaduras de extremidade das tábuas . . . . . . . . . . 97

25 Freqüência de tábuas com e sem rachaduras, das 15 espécies de Eucalyptus. . .

26 Perdas em volume de madeira serrada, como conseqüência das rachaduras de extremidade das tábuas. . . . . . . . . . . . . . . . 99

27 Rachaduras de extremidades de tábua em função da altura na árvore . . . . . . 100

28 Encurvamentos das 15 espécies de Eucalyptus . . . . . . . . . . . . . . 105

29 Variação do encurvamento e do índice de rachadura ao longo do diâmetro da tora, nas 15 espécies de Eucalyptus, casca a casca passando pela medula . . . 108

30 Comportamento das peças serradas e da peça remanescente quando desdobrada em serra fita simples, segundo a técnica de cortes tangenciais sucessivos . . . . . . . . . . . . . . . . . . . . . . . 113

31 Rendimentos da madeira desdobrada, considerando as médias com e sem 118 casca. . . . . . . . . . . . . . . . . . . . . . . . . . .

32 Rendimento em madeira serrada verde (RMS) base tora sem casca, para o conjunto das 90 toras de eucaliptos. . . . . . . . . . . . . . . . .

33 Rendimento em madeira serrada (RMS) base tora sem casca, para o conjunto, das quinze espécies de Eucalyptus.

34 Rendimento em madeira serrada (RMS) dentro de toras.

35 Rendimento em madeira serrada dos subgêneros Symphyomyrtus, Monocalyptus e Corymbia, em função do diâmetro da tora.

36 Rendimento em madeira serrada (RMS), em função das rachaduras de extremidade de tábuas (IR), para o universo de 90 toras.

37 Rendimento em madeira serrada dos subgêneros Symphyomyrtus, Monocalyptus e Corymbia, em função das rachaduras de extremidade de tábua . 126

38 Rendimento em madeira serrada em função da conicidade para o conjunto de 90 toras de eucaliptos.

39 Rendimento em madeira serrada em função da conicidade e posição da tora na árvore. 
40 Relação entre rendimento em madeira serrada (RMS) e conicidade, dentro de espécies e de subgênero . . . . . . . . . . . . . . . . . . . . . . . . . . 129

41 Rendimento em madeira em função do encurvamento da tábua para o conjunto das 90 toras de eucalipto. . . . . . . . . . . . . . . . . . . . . . 130

42 Rendimento em madeira serrada (RMS), em função do encurvamento da tábua. 131

43 Relação entre rachaduras de extremidade de tábuas e encurvamento para o universo de 90 toras de Eucalyptus. . . . . . . . . . . . . . . . . . . . . . . 132

44 Relação entre Rachaduras de extremidade de tábuas (IR) e encurvamento, dentro de espécies de Eucalyptus.

45 Índice de rachadura de extremidade das tábuas em função dos diâmetro médio da tora, para o conjunto das 90 toras de 15 espécies de Eucalyptus.

46 Índice de Rachadura de extremidade de tábua em função do diâmetro, dentro de espécie e de subgênero.

47 Encurvamento das tábuas em função do diâmetro das toras, nas quinze espécies de Eucalyptus. . . . . . . . . . . . . . . . . . . . .

48 Encurvamento em funçảo do diâmetro médio da tora, dentro das espécies. . . . 137

49 Dureza na direçảo normal às fibras, de quinze espécies de Eucalyptus. . . . . . 140

50 Classificação do Eucalyptus em classes de dureza . . . . . . . . . . . . . 141

51 Aparência da madeira das 15 espécies de Eucalyptus . . . . . . . . . . . . . 142

52 Defeitos e qualidades acumulados, na madeira serrada de Eucalyptus, em ordem crescente de negatividade dentro dos subgêneros.

53 Defeitos acumulados na madeira serrada de Eucalyptus, hierarquizado no gênero.

54 Defeitos na madeira serrada de Eucalyptus, entre os subgêneros 


\section{LISTA DE TABELAS}

1 Comparação no rendimento em (\%) na serragem, antes e após o tratamento

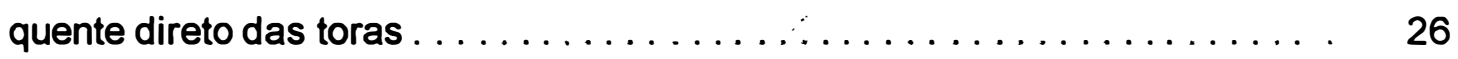

2 Classificação da dureza da madeira de acordo com a SUDAM/IPT ....... 46

3 Classificação da dureza da madeira em oito espécies de eucalipto . . . . . . . 47

4 Características do material estudado. ...................... 50

5 Dados dendrométricos das quinze espécie de Eucalyptus . . . . . . . . . . 63

6 Análise de variância efetuada para a variável diâmetro .............. 64

7 Comparação dos diâmetros médios das toras com casca ............. 65

8 Percentagem de albumo nas quinze espécies de Eucalyptus . . . . . . . . . . 67

9 Análise da variância aplicada às médias de percentagem de albumo nas

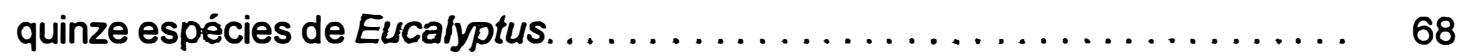

10 Comparação da percentagem de alburno dos subgêneros de Eucalyptus .... 69

11 Comparação da percentagem de alburno, pelo teste de Bonferroni . . . . . . . 69

12 Estatisticas descritivas das percentagens de casca ............... 73

13 Análise da variância da percentagem de casca das quinze espécies de Eucalyptus.................................. 74

14 Percentagem de casca dos subgêneros de Eucalyptus, comparados pelo teste de Bonferroni . . . . . . . . . . . . . . . . . . . . . . . . . 74

15 Comparação das médias de casca pelo teste de Bonferroni ............ 75

16 Conicidades médias de toras, sem casca. . . . . . . . . . . . . . 81

17 Análise da variância aplicada à conicidade de toras sem casca . ......... 82

18 Conicidade média de toras sem casca dos 4 subgéneros ........... . 82

19 Teste de comparação múltipla de Bonferroni para conicidade . . ......... 83

20 Incidẻncia média de nós, obtido por face nas tábuas .............. 85 
21 Análise da variância da Incidência média de nós, por face das tábuas . . . . .

22 Quantidade média de nós por subgênero, comparados pelo teste de Bonferroni . . . . . . . . . . . . . . . . . . . . . . . .

23 Comparação da freqüência de nós por face de tábua, pelo teste de Bonferroni. . . . . . . . . . . . . . . . . . . . . . . . 88

24 Índice de rachadura de extremidade de tábua (IR) . . . . . . . . . . . . . 93

25 Análise de variância do índice de rachaduras de extremidade de tábua . . . 94

26 Índice de rachaduras de extremidade de tábua . . . . . . . . . . . . . . . 95

27 Comparação das médias de rachaduras, nas quinze espécies e subgêneros. 96

28 Encurvamento médio em tábuas de 2,80 m de comprimento . . . . . . . . . . 102

29 Análise da variância dos encurvamentos médios . . . . . . . . . . . . . 103

30 Comparação dos encurvamentos das tábuas nos subgêneros. . . . . . . . . . . 104

31 Encurvamentos nas quinze espécies de Eucalyptus, pelo teste de Bonferroni 104

32 Rendimento em madeira serrada verde para toras sem casca . . . . . . . . . 114

33 Análise da variância para o rendimento em madeira serrada . . . . . . . . . . 115

34 Rendimentos em madeira serrada dos subgêneros de Eucalyptus . . . . . . . 116

35 Rendimentos em madeira serrada dentro de subgêneros e dentro do gênero 116

36 Escala de classificação dos Coeficientes de Correlação de Spearman, (CCS), proposta por Rugg (1979). . . . . . . . . . . . . . . . . . . . . . . . . 120

37 Parâmetros das correlações de Spearman. . . . . . . . . . . . . . . . . 121

38 Niveis de significância, do rendimento em madeira serrada em função dos diâmetros, dentro de espécies. . . . . . . . . . . . . . . . . . 123

39 Niveis de significáncia entre o rendimento em madeira serrada e o índice de rachaduras de extremidade de tábuas dentro de espécies. . . . . . . . . . . . 125

40 Nivel de significáncia entre rendimento e a conicidades das toras nas quinze espécies de eucalipto . . . . . . . . . . . . . . . . . . . . 128

41 Niveis de significáncia das relações entre o rendimento em madeira serrada e o encurvamento das tábuas dentro de espécies de eucalipto . . . . . . . . . . 130

42 Nivel de significância entre as rachaduras em função dos encurvamentos 132

43 Nivel de significância entre, as rachaduras e os diâmetros . . . . . . . . . . . . 134 
44 Nivel de significância entre os encurvamentos em função dos diâmetros das quinze espécies de eucalipto.

45 Dureza (Janka), médias em (Mpa), das quinze espécies de Eucalyptus, na condição seca ao ar .

46 Comparação múltipla de Bonferroni, da Dureza da madeira, entre os subgêneros de Eucalyptus .

47 Durezas das quinze espécies de Eucalyptus, dentro dos subgêneros gênero

48 Fatores de ajuste utilizado para hierarquizar os defeitos e qualidades de Eucalyptus para produção de madeira serrada. 


\title{
POTENCIALIDADE DE ESPÉCIES DE EUCalyptuS PARA PRODUÇÃO DE MADEIRA SERRADA
}

\author{
Autor: VITOR GONZAGA BARCHET \\ Orientador: Prof. Dr. JOSÉ NIVALDO GARCIA
}

\section{RESUMO}

O objetivo do presente estudo foi analisar comparativamente quinze espécies de Eucalyptus, de quatro subgênero diferentes, do ponto de vista da produção de madeira serrada. Foram levadas em consideração nove variáveis, principalmente, aquelas que são manifestaçöes diretas das tensões de crescimento. As espécies estudadas foram, na maioria, espécies ainda desconhecidas no cenário madeireiro Brasileiro como o Eucalyptus pellita, E. citriodora, E. cloeziana, E. microcorys, E. phaeotricha, E. maculata, E. paniculata, E. pilularis, E. pyrocarpa, E. propinqua, E. resinifera, E. saligna, E. tereticornis, E. torelliana e o E. urophylla. As árvores selecionadas, de idade variando entre 17 e 21 anos foram serradas em uma serra de fita simples segundo a técnica de cortes tangenciais semi-balanceados. Todas as espécies foram organizadas em ordem decrescente de qualidade, tanto dentro do gênero como dentro de subgêneros. O subgênero Corymbia foi superior ao Monocalyptus Symphyomyrtus e ldiogenes e dentro dele destacou-se o $E$. torelliana. As demais espécies apresentaram defeitos superiores aos do $E$. 
torelliana, mas a grande variabilidade observada entre árvores, para a maioria das variáveis estudadas, indica a grande potencialidade de novas espécies. Foi possivel observar uma magnífica variação de cores as quais não podem sequer ser imaginadas pela observação externa da casca ou do fenótipo global das árvores. Concluiu-se que a potencialidade do gênero Eucalyptus para serraria é enorme mas, há a necessidade de um amplo trabalho de melhoramento florestal de espécies novas e um adequado manejo florestal orientado para a produção de madeira serrada.

Palavras chaves: Eucalyptus, desdobro do eucalipto, serraria, rachadura de extremidade de tábua, empenamento, qualidade da madeira, aparência. 


\title{
POTENTIALLY OF EUCALYPTUS SPECIES FOR SAWN WOOD PRODUCTION
}

\author{
Author: VITOR GONZAGA BARCHET \\ Adviser: Prof. Dr. JOSÉ NIVALDO GARCIA
}

\section{SUMMARY}

The objective of the present study was to analyze comparatively fifteen Eucalyptus species, belonging to four different sub-genus, from the sawn wood production point of view. Nine variables were taken into account mainly those which are growth stresses directly related. The studied species which were mostly those which are still unknown in the Brazilian wooden scenario like Eucalyptus pellita, E. citriodora, E. cloeziana, E. microcorys, E. phaeotricha, E. maculata, E. paniculata, E. pilularis, E. pyrocarpa, E. propinqua, E. resinifera, $E$. saligna, E. tereticornis, E. torelliana e o E. urophylla. The selected trees were 17 to 21 years old and were sawed in a simple band saw according to the tangential semi-balanced cut technique. After comparison all species were organized from the higher to the lower quality within the Eucalyptus genus and within Eucalyptus sub-genus as well. The sub-genus Corymbia was superior to Monocalyptus, Symphyomyrtus and Idiogenes and inside of it has detached the E. torelliana. The other species presented higher defects than $E$. torelliana but 
the great variability observed between trees for the most studied variables indicate a great potentiality of those new species. It was possible to see a magnificent variation of colors, which cannot be imagined from the external observation of the tree bark or from the tree global performance. It was concluded that the Eucalyptus genus potentiality for saw logs is enormous but there is strong necessity of a big forest improvement program for those new species and an adequate forest management toward sawn wood production.

Key words: Eucalyptus, eucalypt sawing, sawmill, board end splitting, cupping wood quality, appearance. 


\section{INTRODUÇÃO}

A madeira tem sido um dos principais materiais usados pelo homem, através dos tempos, em inúmeras utilidades. Nos últimos anos, a madeira tem sido substituida em muitos usos pelo aço, alumínio, concreto, plástico e pôr várias combinações desses materiais. No entanto, a madeira é um material intensamente explorado e utilizado nos paises economicamente desenvolvidos. A madeira sempre terá seu lugar garantido, em função de suas características físicas, flexibilidade e possibilidade de ser processada ou transformada para múltiplos usos, partindo de sua forma "in-natura".

Segundo a Revista da Madeira (2000), a exportação brasileira de madeira serrada/desdobrada em 1999 alcançou a cifra de US\$ 487,3 milhões, representando $35,03 \%$ das exportações brasileiras. Seguiram depois as exportações de madeira compensada com US\$345,07 milhões, representando $24,80 \%$, e de janelas, portas e armações que participaram com US $\$ 171,13$, representando 12,30 \% do total. Esses valores representam a preferência da sociedade por produtos oriundos de madeira sólida não processada ou "innatura", em função das diversas vantagens que oferecem, como menor custo de processamento, maior durabilidade, resistência, renovabilidade e a apreciável aparência estética da madeira.

A madeira é um dos itens de maior produção anual, superando por exemplo, os itens de alimentação. A produção anual chega a 3352 milhões de toneladas, enquanto que todos os cereais somam a 1533 milhões de toneladas. Seguem o cimento com 930 milhões de toneladas, alimentos plantados abaixo da terra (batata, aipim, etc.) com 530 milhões de toneladas, ferro com 505 milhões de toneladas, e outros, (Revista da Madeira, 1992). 
O setor florestal no Brasil caracteriza-se por deter em torno de $30 \%$ das florestas do mundo e por ter implantado nos últimos 20 anos, mais de seis milhões de hectares de florestas, na sua maioria, eucaliptos e pinus.

Segundo Donnelly et al. (1996) as plantações de eucaliptos abrangiam uma área de 2,9 milhões de hectares, sendo grande parte dessa área já replantada. Cerca de 1,3 milhões de ha estavam ligadas à produção de celulose e papel e 1,6 milhões de ha foram plantados para a produção de carvão vegetal. Entretanto a indústria siderúrgica tem estado substituindo o carvão vegetal por outros redutores minerais. Com isto, suas plantações estão sendo utilizadas para outras finalidades.

O Brasil é um país privilegiado por apresentar condições edafoclimáticas e territoriais muito favoráveis ao desenvolvimento das atividades florestais e por nele existirem muitas espécies arbóreas, naturais ou plantadas de interesse econômico. O mercado interno de madeira serrada é amplo e com possibilidades de conquistar melhores posições no cenário internacional. A tecnologia desenvolvida tanto na formação de florestas como na utilização da matéria prima florestal permite ao País situar-se entre os grandes supridores mundiais de produtos à base madeira. Neste contexto, a utilização de madeiras oriundas de reflorestamento para produtos sólidos vem alcançando maior destaque.

O gênero Eucalyptus é o mais bem sucedido, devido ao seu rápido crescimento, grande diversidade de espécies e uma opção segura a uma ampla gama de propósitos industriais. O eucalipto tem-se apresentado como excelente opção, em função de sua diversidade, adaptabilidade, potencial de produção e características físicas e mecánicas, que permitem várias utilizaçōes, tais como celulose, madeira serrada de diversas bitolas, movelaria, postes, energia, indústria química e farmacêutica.

Ferreira (1979) afirma que num programa de reflorestamento em pequenas e médias propriedades, o sucesso do empreendimento dependerá, além das exigências silviculturais de cada espécie, da utilização final da 
madeira. A escolha da espécie deverá ter como base a utilização final da madeira. Tratando-se de plantações cuja finalidade principal é o atendimento da demanda regional, elas são caracterizadas por pequenas áreas plantadas e pela descontinuidade. Em tais casos, devem ser escolhidas espécies, cuja madeira possa ter utilizações múltiplas.

Fleisher (1971) enumera e descreve 12 características que fazem da madeira um material de excepcional qualidade para usos diversos. Essas características são: densidade, durabilidade, valor isolante térmico e acústico, resistência elétrica, resistência à corrosão química, trabalhabilidade, alta relação resistência - peso, dureza, aparência, facilidade de emenda ou ligação, plasticidade e estrutura fibrosa.

Galvão (1976) já alertava para uma escassez generalizada das espécies mais tradicionais, culminando com a elevação dos preços e restrições na legislação do código florestal. A escassez que vem se efetivando realmente tem forçado o uso de madeiras de qualidade inferior, para diferentes usos. Nessas condições as espécies do gênero Eucalyptus têm sido cogitadas por apresentarem rápido crescimento, fornecendo maiores volumes de madeira a ciclos reduzidos.

Os plantios de eucaliptos efetuados desde o início do século, são as maiores reservas acessíveis e exploráveis da região Sul e Sudeste do Brasil. Seus povoamentos concentram-se próximos aos grandes centros consumidores. Não há previsões de escassez desta matéria-prima devido às curtas rotaçőes.

No Brasil, à semelhança de outros países tropicais, tem-se verificado ao longo dos séculos uma contínua e progressiva degradação da vegetação natural original. Santos ${ }^{1}$ considera que mais recentemente, aumentaram-se as restrições ao uso indiscriminado dos solos sob floresta visando coibir a

1 SANTOS, P.E.T. Características tecnológicas da madeira de Eucalipto para serraria, ESALQ, 1999. 87p. (Monografia não publicada) 
exploração ilegal de madeira. Maior esclarecimento ecológico da sociedade e mudanças de comportamento mercadológico abriram espaço para o avanço de sistemas de produção florestal mais racionais onde a sustentabilidade e o gerenciamento ambiental são considerados prioritários.

Oliveira (1997) também afirma que os primeiros reflorestamentos incentivados foram feitos com o objetivo de produzir matéria prima para a indústria de papel e celulose, para a produção de carvão vegetal, ou para a produção de energia. Atualmente, além destas utilizações, pode-se destacar o uso da madeira de eucalipto na produção de chapas de fibra e em menor escala no setor de eletrificação (postes e cruzetas), na construção civil, na confecção de embalagens e atualmente em escala crescente na indústria moveleira.

Com a devastação das florestas naturais na região sul e sudeste e à quase extinção de algumas espécies nativas de madeira de boa qualidade e estabilidade, as empresas florestais estäo buscando uma alternativa que venha substituir ou amenizar a falta de matéria prima para serraria. Esta busca está recaindo sobre os eucaliptos, que além de ter um crescimento rápido em relação às espécies nativas, apresentam características importantes de uma madeira de boa qualidade. As grandes empresas já estão fazendo grandes investimentos para transformar o eucalipto em fonte potencial de matéria prima para a construção civil e industrialização em geral.

De acordo com Oliveira (1997), o gênero Eucalyptus, possui um enorme potencial quanto ao suprimento de madeira para os mais variados fins. A madeira proveniente de reflorestamentos manejados para obter material de alta qualidade se tornará, em breve, dominante em todas as instâncias do setor madeireiro.

O gênero Pinus, mesmo produzindo madeira de fácil processamento e trabalhabilidade, apresenta propriedades mecânicas insatisfatórias. 0 mesmo não acontece com os eucaliptos cujas resistências mecânicas não sofrem restrições, tendo em vista que suas espécies apresentam valores variando de 
baixo a muito elevados. O principal desafio é o de direcionar adequadamente os eucaliptos à indústria moveleira e a alguns setores da construção civil, uma vez que sua introdução no Brasil foi efetuada para a produção de matéria prima para energia de transporte ferroviário, para a indústria de papel e celulose e para a industria siderúrgica.

A potencialidade dos eucaliptos na substituição de espécies nativas apresenta-se como um processo irreversível, justificando a necessidade de pesquisas para o embasamento técnico e científico de suas adequadas utilizações, Benedetti².

$\mathrm{O}$ autor ressalta ainda que, mais recentemente, tem sido notório o interesse de diversas empresas florestais na produção de madeira serrada, entre elas a Klabin, Aracruz, Flosul, CAF, Eucatex e Champion. Estas empresas desenvolvem projetos visando a caracterização e seleção de árvores para serrarias. Apesar disso a disponibilidade de áreas plantadas com eucaliptos ainda não selecionados para serraria e o aumento da demanda de madeira para este fim, obriga os serradores de pequeno e médio porte a um aproveitamento otimizado dos produtos gerados, visando a obtenção de maiores ganhos económicos na produção.

Otte (2001) afirma que o eucalipto procedentes de reflorestamentos, substitui as nativas de origem tropical com propriedades amplamente vantajosas e está sendo cada vez mais aceito no mercado nacional e exterior. O êxito do eucalipto é tal que já o definem como a madeira da moda.

Durante o período de 1996 a 1998, o Setor de Sementss do IPEF ESALQ-USP, comercializou $3.113,30 \mathrm{~kg}$ de sementes do gênero Eucalyptus, o que corresponde a ,aproximadamente, $55 \%$ do total comercializado, Pinus 9,5 $\%$ e nativas/exóticas $35,5 \%$. As espécies mais comercializadas dentro do gênero Eucalyptus foram: $E$. urophylla 24,76 \%, E. citriodora $22 ; 07 \%$, $E$.

\footnotetext{
2 BENEDETTI, V. Uso múltiplo da madeira de eucalipto otimizado através da programação linear. Piracicaba: ESALQ, 2000. 35p.
} 
saligna $10,37 \%$, E. pellita $1,97 \%$, E. tereticornis $0,86 \%$, E. cloeziana $0,79 \%$ e E. resinifera $0,77 \%$. As demais espécies incluidas no presente trabalho atingem $5 \%$.

As principais dificuldades no processamento da madeira de eucalipto para serraria, e que são de difícil controle são: a tendência ao rachamento das extremidades das toras antes do desdobro, a tendência ao rachamento das tábuas durante e após o desdobro e a tendência ao empenamento das tábuas durante o desdobro. Esses defeitos sempre ocorrem com maior ou menor intensidade neste processo de transformação, mesmo que técnicas adequadas de desdobro sejam utilizadas.

Diversos são os estudos já realizados para avaliar as tensões existentes em árvores, manifestadas através dos empenamentos das peças serradas e das rachaduras, tanto nas extremidades das toras como nas extremidades das tábuas de eucaliptos. Todavia, a maioria dos trabalhos foi conduzida sobre uma ou poucas espécies, empregando materiais e metodologias distintos. Os diferentes resultados de intensidades de rachaduras e empenamentos das tábuas năo permitem uma análise comparativa das manifestações das tensões de crescimento entre as espécies. Assim o presente trabalho teve por objetivo estudar, analisar, comparar e divulgar as características de quinze espécies de eucalipto, completamente desconhecidas no setor de produção de madeira serrada. 


\section{REVISÃO DE LITERATURA}

\subsection{Natureza e origem das tensठ̃es de crescimento}

A madeira de espécies arbóreas de rápido crescimento, especialmente de folhosas como o gênero Eucalyptus, têm propensão a apresentar rachaduras em toras e tábuas, assim como diversos tipos de empenamentos durante o desdobro Todos esses defeitos são provocados pelas tensões de crescimento, que ocorrem normalmente nas árvores e que garantem a estabilidade física do tronco vivo.

As tensões de crescimento recebem este nome por serem geradas durante a formação das células de madeira e por se acumularem ao longo do crescimento da árvore.

As rachaduras de topo da tora manifestam-se instantaneamente ao abate da árvore, devido à liberação das tensões de crescimento existentes, que se encontravam equilibradas.

Há várias teorias sobre as causas das tensões de crescimento. De acordo com Kubler (1987), os cientistas que as tensões de crescimento são tensões encontradas em fuste de árvores vivas e possuem os componentes longitudinal, tangencial e radial. Estas tensões não devem ser confundidas com as tensões resultantes do peso da copa da árvore, que cria uma tensão de compressão no fuste ou do peso próprio do galho que provocam uma tensão de tração no lado superior e uma tensão de compressão no lado inferior. Estas tensões resultam da ação externa da gravidade, enquanto que as tensões de 
crescimento são auto-geradas. Elaș evoluem na árvore em crescimento e são um tipo de tensão interna ou residual, a qual existe naturalmente dentro de um corpo sólido, onde não existe nenhuma força externa causadora de tensão, da tensão da seiva, ou ainda resultante da madeira de reação e das tensões geradas pela secagem.

Em 1945 Jacobs afirmava que as tensões de crescimento originavamse no câmbio, tecido responsável pelo crescimento diametral das árvores, formando uma camada periférica que permanecia com o mesmo nível de tensão ao longo da vida da árvore. O mecanismo de geração destas tensões de crescimento consiste no encurtamento longitudinal e expansão lateral das células (Boyd, 1972). Este encurtamento gera uma tensão de tração longitudinal próximo ao câmbio da árvore, a qual decresce gradativamente na direção da medula mudando de tração para compressão longitudinal. A expansão lateral provoca uma compressão na direção tangencial e uma tração na direção radial, sendo esta última de valor nulo na periferia pois a casca não provoca resistência nesta direção (Kubler, 1987).

Conforme Wilkins (1986), as tensões de crescimento são tensões mecânicas encontradas dentro de árvores vivas ocorrendo nas direçōes tangencial, radial e longitudinal, sendo esta última, a forma mais severa, com distribuição variando progressivamente de tração na periferia do fuste até a máxima compressão no centro próximo a medula.

Segundo Vignote et al. (1996), as tensőes de crescimento são devidas ao constante crescimento das células produzidas na região do câmbio e que no crescimento secundário tendem a expandir-se lateralmente e a contrair-se longitudinalmente, mas as células formadas nos anos anteriores, além de dificultarem este crescimento, geram um conjunto de tensões que seguem as direções clássicas da madeira. As magnitudes das tensões diferenciam dependendo da direção que se considera, assim, as tensões na direção axial é aproximadamente dez vezes superior às tensões transversais e dentro destas 
últimas, as tensões tangenciais são maiores do que as tensões radiais. A magnitude das tensões varia enormemente com a espécie, entre indivíduos de mesma espécie e dentro de um mesmo indivíduo, ao longo da altura da árvore e também ao longo do raio.

\subsubsection{Organização da parede celular}

Segundo Durlo \& Marchiori (1995) existe entre duas células lenhosas adjacentes, uma camada isotrópica chamada lamela média. No estágio cambial de formação celular bem como durante a fase de crescimento da célula, esta camada consiste fundamentalmente de substância pécticas e é por natureza muito plástica, possibilitando a expansão da parede primária durante o crescimento.

Segundo os mesmos autores, a parede primária situa-se internamente à lamela média. Trata-se de uma fina camada celulósica, com cerca de 0,1 $\mu \mathrm{m}$ de espessura. Na madeira seca, a contração reduz sua espessura para apenas $0,03 \mu \mathrm{m}$. A parede primária consiste de aproximadamente $9 \%$ de celulose, achando-se embebida por uma matriz amorfa e plástica de hemicelulose, substâncias pécticas e lignina e cerca de $70 \%$ de água, quando na árvore viva. $\mathrm{Na}$ porção mais externa da parede primária, a celulose apresenta-se entrelaçada, sem arranjo reticular definido. Na região mais interna da parede primária, as células celulósicas formam ângulos de aproximadamente $15^{\circ} \mathrm{com}$ a direção longitudinal da célula. Parte das microfibrilas dispõem-se em uma direção e parte em direção oposta.

Em células lenhosas, tais como fibras e traqueídes, a parede secundária consiste geralmente de três camadas. Uma externa $\mathrm{S} 1$, muito fina apresentando microfibrilas em orientação helicoidal, quase transversal à célula.

Uma camada $\mathrm{S} 2$, que é mais espessa, apresentando microfibrilas quase paralelas ao eixo longitudinal celular. $\mathrm{Na}$ camada mais interna $\mathrm{S} 3$, as 
microfibrilas dispõem-se em grandes ângulos com a direção do comprimento da célula.

A camada S2 consiste de uma densa organização de cadeias celulósicas, em alinhamento quase paralelo ao comprimento da célula no lenho adulto. No lenho juvenil este ângulo geralmente é maior. Devido à sua grande espessura em relação às demais camadas a S2 é a que tem maior influência sobre a retratibilidade da madeira e sobre as tensões internas de crescimento.

As causas das diferenças de contração e inchamento segundo as direções anatômicas, estão na organização da parede celular lenhosa.

A tensão de tração existente na periferia da árvore é causada pelo encurtamento das fibras durante o desenvolvimento da parede secundária. Segundo Wilkins (1986), este encurtamento pode ser devido a duas causas, que são por enquanto hipóteses: inchamento por deposição de lignina e tração da celulose. A primeira hipótese foi citada por Wilkins (1986), que sugere que a deposição da lignina durante a diferenciação celular, resulta no inchamento da parede celular, e caso o ângulo das microfibrilas da camada S2 seja menor que $40^{\circ}$ ocorrerá encurtamento da célula, e se for maior que $40^{\circ}$ ocorrerá alongamento. A outra hipótese sugere que 0 encurtamento das células periféricas surge como resultado da contração dos cristais de celulose, nas microfibrilas da camada $\mathrm{S} 2$, e como na hipótese anterior é o ângulo das microfibrilas desta camada que definirá se a célula encurtará ou alongará.

Quando uma célula recém formada começa a espessar suas paredes, ela tende a aumentar seu diâmetro e a reduzir seu comprimento. Ao tender a expandir-se diametralmente, comprime-se contra as células vizinhas laterais, gerando tensões de compressão tangenciais. Simultaneamente, toda a camada de células tende a aumentar o diâmetro, tracionando a madeira antiga na direção radial. A porção central passa a receber uma tração tangencial crescente, gerada pela ação acumulativa das camadas mais jovens. Esse efeito das camadas mais jovens sobre aquelas que estavam em compressão inicial, 
devido à sua tendência de expansão e restrição de células vizinhas, faz com que a uma certa distância do câmbio ocorra uma inversão no sentido da tensão e que a parte mais interna da madeira passe a estar sob tração.

Após a formação pelo câmbio, durante o espessamento da parede, as células tendem a encolher-se e são impedidas pelas células das camadas mais antigas de madeira. Assim, a camada mais externa sofre a ação de forças de tração que a mantém no seu comprimento original. Este fato se repete a cada nova camada de células formada no câmbio. O aparecimento de novas camadas de células no câmbio também tem um efeito sobre a tensão de camadas mais internas de células.

\subsubsection{Madeira de reação ocasionada pelas tensões de crescimento}

As tensões de crescimento são geradas durante a maturação das paredes celulares. As tensões são criadas sucessivamente durante o crescimento secundário, mas certas tensões de tração são acumuladas na parede celular durante 0 período de crescimento devido aos novos componentes adicionais relacionados às tensões de relaxamento e das propriedades visco-elásticas da parede celular Okuyama (1997).

Segundo o mesmo autor, as fibras de madeira normal sem lenho de reação e traqueídes, geram trações e tensão de crescimento compressiva nas direções axial e transversal respectivamente. A camada mais externa do tronco, forma uma massa de fibras lenhosas ou traqueídes, que produzem as tensões mensuráveis: tensão de crescimento de tração na direção longitudinal e tensão de compressão na direção tangencial, já mencionadas anteriormente.

A tensão localizada da madeira de reação e a tensão de crescimento se acumulam resultando na distribuição, mostrada na Figura 1. 


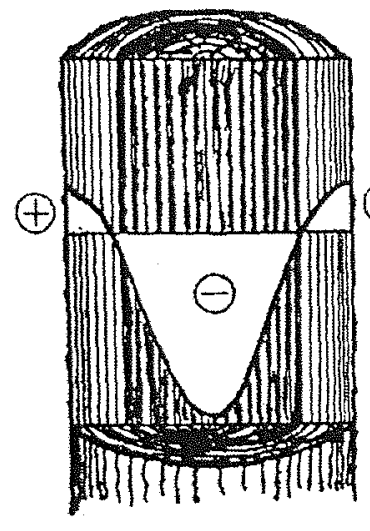

(a)

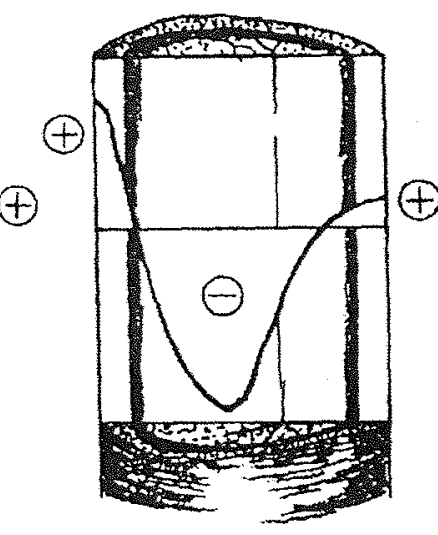

(b)

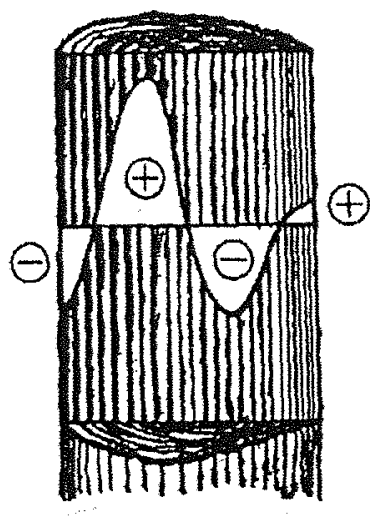

(c)

Figura 1 - Distribuição das tensões residuais nos troncos que contém lenho de reação.

(a) Tronco não contendo lenho de reação

(b) Tronco contendo lenho de tensão no lado esquerdo

(c) Tronco contendo lenho de compressão no lado esquerdo

$(+)$ tensão de tração $\quad(-)$ tensão de compressão

A Figura 1 mostra a distribuição esquemática das tensões residuais longitudinais no tronco, que contem lenho de reação. A tensão residual da parte mais externa do tronco, coincide com a tensão de crescimento gerada anualmente.

As tensões periféricas e consequentemente as deformações periféricas, aparecem na camada mais externa do lenho e são renovadas cada vez que uma nova camada passa pelo processo de maturação durante toda a vida da árvore. As tensões transversais podem ser radiais ou tangenciais. As radiais podem ser desprezadas uma vez que a casca oferece pouca resistência ao crescimento da árvure.

Segundo Grosser (1979), o lenho de tração é normalmente brilhante e mais claro, de coloração branca a prateada, via de regra, reconhecivel em madeira recém cortada. Em madeira seca é detectado microscopicamente através de coloração de cortes delgados. A superfície da madeira apresenta-se sedosa até lanosa. 
A principal característica do lenho de tração é a fibra gelatinosa. A camada gelatinosa é feita de quase pura celulose. $O$ ângulo das microfibrilas é próximo de zero em relação ao eixo axial e possuem grande cristalização. As fibras semelhantes geram grandes tensões de crescimento de tração na direção axial e algumas vezes apresentam contração dez vezes maior que as fibras normais, quando a tensão é liberada. Quando a madeira contém tais tensões fibro-lenhosas, ocorrem grandes arqueamentos na madeira serrada, que no momento do desdobro a madeira pode travar a serra e eventualmente pode parar o processo de desdobro.

As espécies da família Magnoliacea, possuem fibras gelatinosas, mas a fibra da região superior no caule inclinado, tem parede secundária com muita celulose e pequeno ângulo microfibrilar. Neste caso a alta tensão de crescimento de tração na direção axial é o mesmo que nas fibras gelatinosas.

A madeira de reação das árvores de coníferas é chamada de lenho de compressão (letra $c$ na Figura 1). Estes traqueídes apresentam parede secundária espessa com forma arredondada, com elevado ângulo microfibrilar e grande conteúdo de lignina. Os componentes contem traqueídes semelhantes com tensão de crescimento compressivo na direção longitudinal e apresentam grande expansão quando o stress é liberado. Esta expansão também induz arqueamentos ou torcimentos na madeira serrada.

O lenho de compressão situa-se do lado inferior do tronco inclinado ou nos ramos das árvores, no lado sujeito ao esforço de compressão.

Para (Grosser,1979), este lenho apresenta-se em geral com largos anéis de crescimento. A diferenciação entre lenho inicial e tardio é difícil, pois os traqueídes de lenho inicial apresentam paredes espessas, apresentam elevado teor de lignina, conferindo uma coloração avermelhada. Num corte transversal é reconhecivel pelas zonas de lenho mais escuro, marromavermelhadas em forma de foice. 
As características microscópicas deste lenho apresentam-se nas coniferas, traqueides com paredes arredondados em corte transversal de forma a surgirem espaços intercelulares. Os traqueides são mais curtos que os normais. A parede secundária apresenta fendas delgadas e não apresenta a parede terciária. $O$ ângulo de orientação fibrilar é muito pequeno, quase horizontal, ou transversal ao eixo axial (Grosser, 1979).

\subsubsection{Fatores externos que influenciam as tensões de crescimento}

Algumas hipóteses de origem das tensões internas na madeira de eucalipto levam em consideração o fator intrínseco da espécie, mas muitas evidências apontam também uma significante influência ambiental (Wilkins, 1986; Kubler, 1987).

Muitos fatores externos, ambientais ou silviculturais, podem influenciar a intensidade das tensões de crescimento entre elas: a taxa de crescimento, desrama, desbaste, espaçamento, manejo florestal, tipo de solo e os ventos.

Para se conhecer a variação das tensões perimetrais em uma determinada secção da árvore, Vignote et al. (1996) avaliaram as tensões perimetrais nas direções $N, S, E$ e $W$, e concluiram que as tensões leste e oeste diferiam significativamente entre si, enquanto que as tensões norte e sul não diferiam. A Justificativa da variabilidade encontrada pode ser explicada pelos efeitos dominantes do vento na região de Galícia, cuja direção predominante é de leste para oeste. Este vento predominante produz madeira de compressão no lado oeste, que faz aumentar os valores da deformação na madeira e as tensões de crescimento.

Nicholson (1971) demonstrou que não há relação entre taxa de crescimento e o valor de tensão de tração periférica, embora haja considerável variação entre os valores de tensão, entre árvores, mesmo elas estando 
próximas. Essa observação demonstra que as tensões de crescimento devem estar substancialmente controladas por fatores genéticos.

Wilkins \& Kitahara (1991), estudando árvores de Eucalyptus grandis de 22 anos de idade e diâmetros diferentes, concluíram que não houve correlação significativa entre as deformações periféricas longitudinais oriundas das tensões de crescimento, com a taxa de crescimento. Os autores sugerem que o gradiente das deformações, da medula para a casca, é menor em árvores de maior diâmetro. Isto implica que indivíduos de diâmetros maiores produzem tábuas menos susceptíveis a empenamentos que árvores com diâmetros menores.

Okuyama (1997) concluiu que não houve a relação entre o nivel de tensão de crescimento e a taxa de crescimento de Cryptomeria japonica, uma típica espécie de conífera de rápido crescimento no Japão. O mesmo autor comenta que as árvores próximas aos pólos, no hemisfério norte, crescem durante décadas geralmente sob condições de exposição a intempéries, vento e neve. Durante seu crescimento, as árvores controlam a forma do fuste e a ramificação, a fim de posicionar as folhas na direção da luz do sol, mesmo estando em terrenos inclinados. Durante o crescimento, tensões internas são geradas na zona cambial, as quais são denominadas tensões de crescimento. Portanto, as tensões geradas como conseqüência do processo de crescimento são consideradas úteis para o desenvolvimento da árvore

Kubler (1987) comenta sobre o fator desestabilizante dos desbastes, e afirma que, este manejo pode mudar o padrão de iluminação da árvore, provocando reorientação dos ramos e do fuste, em função do fototropismo, e aumentando assim as tensões. O autor conclui, que os plantios devem ser desbastados levemente e uniformemente. No entanto, Ferrand (1982), estudando Eucalyptus nitens, verificou que os niveis de tensão de crescimento diminuíam à medida que se aumentava a intensidade de desbaste. 


\subsubsection{Variação das Tensões de Crescimento no Tronco}

Hillis (1973) afirma que o nivel de tensão longitudinal gerado num determinado ponto da superfície de um tronco está estreitamente relacionado à estrutura das fibras celulares contidas na madeira e que pode ser predita pôr elas. Nesse sentido, Malan (1984) estudou a associação entre o nivel de tensões de crescimento e diversas características da madeira do Eucalyptus grandis, constatando que as árvores com altos níveis de tensão de crescimento eram caracterizadas pôr elevadas densidades da madeira nas partes externas do lenho, resultando também num elevado gradiente de densidade no sentido medula-casca do tronco. $\mathrm{O}$ autor concluiu ainda que os altos níveis de tensão de tração longitudinal na periferia dos troncos estavam intimamente associados à proporção de fibras com paredes celulares espessas e que essas fibras apresentavam comprimentos maiores, quando comparados com aquelas de árvores com menores níveis de tensão periférica. O referido autor sugere que a redução do nível de tensão de crescimento das árvores pode resultar em madeira de baixa densidade periférica dos troncos e em conseqüência, uma menor variação das propriedades da madeira no sentido medula-casca.

Yao (1979) estudou os níveis de tensão de crescimento em função da posição nos troncos de Fraxinus americana e Quercus nigra, verificando que para estas duas espécies, os níveis de tensão aumentaram no sentido basetopo até uma altura, entre 6 e $9 \mathrm{~m}$ para depois decrescer. Essa tendência foi comprovada estatisticamente através de uma análise de regressão. Entretanto não encontrou diferenças significativas entre estas duas espécies e Shagbark hickory, sugerindo que todas elas tinham a mesma magnitude de tensões.

Chafe (1981) verificou, em um estudo realizado com Eucalyptus regnans, um aumento das tensões no sentido base-topo, mas que não foi comprovado estatisticamente através de correlação. 
Estudando este mesmo tipo de variação das tensões de crescimento em Eucalyptus nitens Chafe, 1985 obteve um resultado contrário ocorrendo, portanto, uma diminuição das tensões no sentido base-topo. Este comportamento foi comprovado através de análise estatística. Uma vez que existe variação do nivel de tensões de crescimento no sentido base-topo, cuja variação pode ser direta ou inversa, depreende-se que o diâmetro contribuirá muito pouco para explicar as variações dos níveis de tensão de crescimento.

Fernandez \& Ferreira (1986), estudando as relações entre o nível de tensões de crescimento e os diâmetros das toras de Eucalyptus saligna encontraram correlações altamente significativas. As deformações causadas pelas tensões internas de crescimento diminuíram com 0 aumento dos diâmetros. Essas conclusões confirmam os estudos de Curro \& Cavidini (1961), que trabalharam com o E. camaldulensis.

\subsubsection{Conseqüências das Tensões de Crescimento}

O fenômeno das tensões de crescimento está presente em todos os gêneros de árvores, mas o gênero Eucalyptus, para Nicholson (1973), é o exemplo mais notável de madeira comercial, onde os níveis de tensão podem ser tão altos, que apresentam como conseqüência a redução de madeira serrada de três modos:

1. Rachaduras de topo de tora que requerem consideráveis operações de destopo;

2. Distorção das toras e tábuas no desdobro que requerem um reprocessamento para obter-se produtos comercializáveis;

3. Cerne quebradiço, também chamado de "brittle heart" que torna esta porção indisponivel para fins onde se necessita de material resistente.

Observa-se comumente, que na prática, toras e toretes empenam e racham durante ou após o desdobro. Esses defeitos estão relacionados com as 
tensões de crescimento, encontrado nas árvores jovens e adultas. Galvão (1976) admite que árvores de Eucalyptus globulus, de diâmetros inferiores a $60 \mathrm{~cm}$, apresentam tensões internas responsáveis pelo aparecimento de fendas ou rachaduras nas peças desdobradas. $O$ aparecimento desse tipo de defeito é conseqüência da utilização de árvores demasiadamente novas.

As tensões de crescimento afetam a utilização da madeira de eucaliptos de várias formas: empenamentos das costaneiras e das tábuas, movimentação da tora na mesa de corte, retenção da serra, rachaduras da tábua diametral, e tábuas de espessura irregular (Chafe, 1979). As rachaduras das tábuas diametrais ocorrem porque, as tensões longitudinais não estão mais balanceadas pelas tensões das tábuas laterais que já foram cortadas, e portanto, as tensões opostas ocorrentes nesta tábua provocam o seu rachamento nas extremidades, na região da medula (Panshin \& De Zeeuw, 1970). Estas rachaduras são igualmente muito freqüentes mas de menor intensidade, nas tábuas adjacentes.

De acordo com Santos et $a^{3}{ }^{3}$, em geral, as tensões longitudinais são as que mais causam defeitos na madeira. Apesar do tronco de uma árvore apresentar tensões desuniformes no seu interior, geralmente não há deformação na madeira até que ela seja cortada no sentido transversal por ocasião do corte ou do desdobro. Neste momento, parte das forças que restringiam a mudança de dimensões das células é liberada e a madeira tende a se comprimir naquelas regiões que estavam sob tração e a se expandir onde estavam sob compressão. Este fenômeno dá origem às rachaduras e empenamento das peças serrradas.

O torcimento pode ser conseqüência natural da grã espiralada contida na árvore, ou devido a condições bruscas de secagem. Algumas espécies de

\footnotetext{
${ }^{3}$ SANTOS, P.E.T.; SCANAVACA, L.; ADORNO, M.F.C. Apontamentos da disciplina LCF-852. Propriedades fisicas e mecânicas da madeira. ESAQ. Piracicaba. (Não publicado). 1998
} 
Eucalyptus apresentam a grã espiralada, como uma caracteristica intrinseca, sendo necessário uma seleção para evitarem-se estes individuos.

O cerne quebradiço é outra conseqüência desastrosa das tensões de crescimento. Com o crescimento da árvore ocorre um aumento da força de compressão e eventualmente esta tensão excede a resistência à compressão da madeira, causando diversas falhas de compressão, que no conjunto dão origem ao cerne quebradiço (Malan, 1995).

Segundo a FAO (1981), além das tensões longitudinais, existem no tronco do eucalipto tensões transversais que se manifestam durante o corte transversal. Os dois tipos de tensões de crescimento podem ou não estar interrelacionados. Os troncos vivos de todos os tamanhos estão comprimidos tangencialmente na sua periferia, o que significa que as células nas camadas mais externas se empurram umas com as outras, tendendo a aumentar o diâmetro do tronco. Esta compressão tangencial cria uma tensão radial sobre a parte interna do tronco, que manifesta um cerne sinuoso de forma estrelada, que irradiam da medula e que constituem um componente comum nas toras cortadas transversalmente de eucalipto.

Como estas forças tangenciais são de magnitudes consideráveis nos caules das árvores, ela induz a formação da grã transversal que em muitas situações se entercruzam, formando a grã intercruzada, comum em caules de portes mais avantajados. Esta grã na direção transversal confere uma maior resistência na madeira, contra a expansão radial no tronco, o que ocasionaria rachaduras longitudinais internas.

Quando o centro de uma árvore está podre, o tronco tende a aumentar o diâmetro na região apodrecida, visto que a tendência das camadas mais externas em expandirem-se, não estão mais controladas pela adesão interna da madeira. Devido a esta tendência, as medidas sucessivas para calcular o crescimento diamétrico na região apodrecida, deixam duvidas em árvores de grande diâmetro e não podem refletir em crescimento em volume do tronco. 
Este fenômeno não se limita por hipótese, ao gênero Eucalyptus, mas em eucaliptos maduros, pode ter uma grande influência no rendimento de desdobro e na indústria de tratamento de postes (FAO, 1981).

Zobel \& Jett (1965) apontam que existe muita variação no ângulo das microfibrilas entre as árvores para justificar uma seleção de clones e produzir madeira mais forte e de melhor qualidade. Quando o ângulo da microfibrila é fechado ou quase paralelo ao eixo axial, a retração tangencial da madeira sob secagem é pequena, mas quando ele é aberto, como é o caso da madeira de reação, madeira juvenil ou ao redor dos nós, a retração longitudinal pode ser grande, chegando até nove vezes aquela da madeira normal. Portanto, quando a peça serrada contém madeira com diferentes ângulos das microfibrilas, elas tornam-se instáveis e empenam, fendilham e torcem. A resistência da peça não está intimamente relacionada com a densidade da madeira, mas parece estar relacionada com o ângulo da microfibrila. Uma das piores características das madeiras de reação e juvenil é o ângulo aberto das microfibrilas, resultando defeitos e depreciação bastante altos.

\subsubsection{Magnitude das tensões de crescimento}

Estudando a variação nas tensões de crescimento ao redor da periferia de uma árvore de 31 anos de idade de $E$. regnans, no Estado de Victoria, Austrália, Hillis (1978) verificou que a magnitude das tensões variam de 3,9 a 5,5 $\mathrm{MPa}$, enquanto em outra árvore não inclinada de mesma idade os valores variavam de 1,9 a 44,7 MPa. Variação similar tem sido obtida em árvore de 70 anos de idade de $E$. obliqua, na mesma região. Em um grupo de 41 árvores de E. regnans e 12 árvores de $E$. obliqua, o valor médio mais alto para uma árvore foi de $16,3 \mathrm{MPa}$, aproximadamente três vezes superior ao valor baixo. Em outro grupo de 24 árvores de 30 anos de idade de $E$. regnans, o valor médio superior foi de 2,5 vezes maior que o mais baixo. Embora o nivel médio de tensões 
longitudinais não pareceu ser uma função da retidão do fuste nas árvores acima, variações maiores foram encontradas ao longo da periferia de árvores inclinadas. A variação na tensão periférica longitudinal está associada à necessidade de manter a árvore em posição vertical ou manter a posição da copa no dossel.

Para a FAO (1981), as forças das tensões existentes são enormes. A tensão de tração média da periferia do tronco é de aproximadamente, de 8,4 $\mathrm{MPa}$. Na parte mais interna do tronco as células se comprimem além da sua capacidade elástica de resistir à compressão longitudinal. Tensão de compressão superiores a $14,0 \mathrm{Mpa}$, podem acontecer no centro de postes compridos de eucaliptos jovens de $15 \mathrm{~cm}$ de diâmetro. Acima destas forças consideráveis, as células de lenho interno podem ceder com o passar do tempo e formar uma grande quantidade de pequenas falhas de compressão nas paredes celulares.

\subsubsection{Procedimentos para reduzir os efeitos oriundos das tensões de crescimento.}

Existem diversos procedimentos que são realizados durante o manejo das árvores e toras, para reduzir ou atenuar os problemas advindos das tensões de crescimento. A derrubada da árvore deve ser realizada na direção onde a queda seja mais suave, evitando-se possíveis choques ou impactos irregulares com o solo, que possam causar flexões exageradas, que ocasionam fendilhamentos internos nos troncos.

Os métodos seguintes são alguns exemplos práticos, de como evitarem-se ou reduzirem-se os defeitos provenientes das tensões residuais nas toras. Antes de tudo é necessário utilizarem-se espécies que tenham menores índices de tensão residual.

O método de cintamento consiste utilizar-se uma cinta para prevenir trincas ou rachaduras transversais que facilmente ocorrem no topo da tora. A 
cinta metálica ou de qualquer material, tem a função de restringir os deslocamentos, evitando-se as rachaduras transversais no topo das toras. A força de alongamento e a rigidez da cinta devem ser determinadas pelo nivel de tensão residual e diâmetro da tora. Este método pode ser usado desde o momento do corte da árvore que tenha altos níveis de tensões de crescimento.

O método do anelamento consiste em efetuar um sulco ao longo da periferia do tronco, dispersando a tensão induzida no topo. $O$ anelamento é feito, normalmente, a cerca de $30 \mathrm{~cm}$ de cada extremidade da tora.

Na África do Sul, conforme comentários de (Malan, 1998), uma leve redução no desenvolvimento de rachaduras foi observado dois meses após anelarem-se as árvores, mas o procedimento foi acompanhado por uma considerável degradação do fuste devido à secagem superficial e danos por brocas de madeira. Ocorreu uma significativa redução das rachaduras em árvores de $E$. grandis mortas ou de crescimento comprometido durante um período de seca severa, mesmo em sítios reconhecidos por produzirem severas rachaduras nas toras.

Van Wyk (1978) relaciona algumas providências que podem reduzir a incidência de rachaduras no topo da tora, melhorando o seu aproveitamento na serraria, sendo elas:

1.Transporte e desdobro das toras num prazo máximo de 30 horas, após o corte da árvore;

2.Transporte das toras para serraria em comprimentos os maiores possiveis;

3. Corte circunferêncial de aproximadamente $30 \mathrm{~mm}$ de profundidade e acima do local de corte da árvore;

4. Descascamento da tora somente na serraria, minutos antes do desdobro;

(Kikuti et all, 1996) recomenda, com base nas experiências conduzidas na empresa Klabin, para a produção de madeira de alta qualidade de 
eucaliptos, que certos cuidados devem ser tomados na preparação das toras. As toras devem ser cortadas com os troncos não flexionados, evitando-se rachaduras internas. No caso serem destinadas para laminação, devem ser aneladas e o transporte para processamento deve ser realizado em um prazo de até três dias.

O método de relaxamento consiste em armazenar a tora em água ou submetê-la a um tratamento a altas temperaturas para induzir deslocamentos entre as fibras e consequentemente $\circ$ relaxamento das tensões. Entretanto este método pode ser considerado um tanto insuficiente por demandar muito tempo e recursos para reduzir a tensão a níveis não problemáticos.

O tratamento de ebulição e vapor é utilizado para amaciar a rigidez das toras tornando mais fácil as operações subseqüentes de corte $\mathrm{e}$ descascamento. A lignina começa a amaciar abaixo de $100{ }^{\circ} \mathrm{C}$ sob condições de umidade, enquanto que a hidrólise da hemicelulose inicia-se a $100{ }^{\circ} \mathrm{C}$. A parede celular plastificada por um tratamento Higrotérmico, libera parte da tensão residual na parede celular.

Segundo Okuyama (1997), o método de aquecimento direto tem sido praticado para reduzir as tensões residuais internas das toras, assim como o conteúdo da umidade inicial das toras verdes. Essas são aquecidas pôr aproximadamente 50 - 60 horas numa temperatura superior a $150{ }^{\circ} \mathrm{C}$, dentro de um forno especial, usando-se restos de madeira como combustível. Este tratamento eleva a temperatura no interior da madeira acima de $100^{\circ} \mathrm{C}$. Pela perda da água livre, das toras verdes, o conteúdo de umidade é reduzido até aproximadamente o ponto de saturação das fibras. Durante esse processo a tensão residual da tora é reduzida.

As mesmas conclusões foram obtidas por Jara et al. (1997), estudando toras de Eucalyptus grandis com idade de 19 anos, provenientes de Lençóis Paulista/SP, que foram submetidas tratamentos térmicos durante 3 diferentes periodos de tempo. As toras foram desdobradas pelo método do quadro cheio, 
que é o mais crítico para detectar-se a presença de tensões de crescimento através das rachaduras das tábuas. Concluíram que o tempo de aquecimento de 67 horas com temperatura média de $64,5^{\circ} \mathrm{C}$, foi o que melhor contribuiu para a redução das tensões de crescimento, embora não diferindo significativamente das médias obtidas dos outros tratamentos de 43 horas à temperatura de $65,6{ }^{\circ} \mathrm{C}$ e 106 horas à temperaturas de $59,3{ }^{\circ} \mathrm{C}$.

A Figura 2, mostra um exemplo de redução das tensões residuais através do tratamento térmico, que reduziu os empenamentos e arqueamentos no desdobro das toras em mais que $2 / 3$.

O nivel de tensão residual e o conteúdo de umidade são reduzidos por este tratamento o efeito secundário da termo degradação da madeira e de aparecimento de rachaduras por secagem da tora. Um forno especial está sendo melhorado atualmente para tratar as toras por um tempo maior e com as operações adequadas de aspersão para minimizarem-se essas rachaduras.

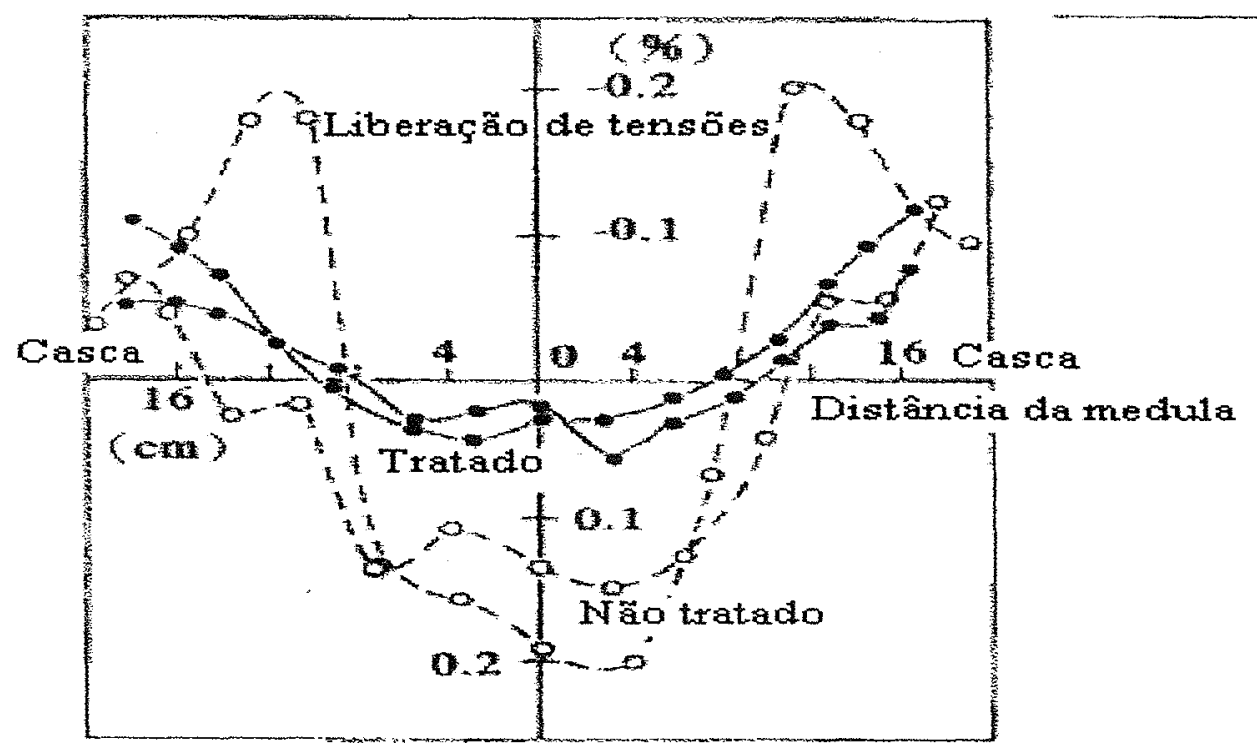

Figura 2 - Distribuição das tensões residuais longitudinais, antes e após o tratamento térmico.

A redução do nível de tensão residual significa aumentar o rendimento no desdobro. Na Tabela 1, pode-se verificar o rendimento no desdobro após o tratamento de mais de $20 \mathrm{~m}^{3}$ de toras estudadas nos experimentos com faia 
japonesa e carvalho. Um incremento no rendimento no desdobro foi alcançado sem a presença das tensões residuais nestas toras.

Tabela 1. Rendimento em (\%) no desdobro, antes e após o tratamento térmico direto das toras.

\begin{tabular}{lcc}
\hline \multicolumn{1}{c}{ Espécie } & Não tratada & Tratada \\
\hline $\begin{array}{l}\text { Fagus crenata. Blume } \\
\text { (Faia japonesa) }\end{array}$ & 43,0 & 46,9 \\
$\begin{array}{l}\text { Quercus sp. } \\
\text { (Carvalho) }\end{array}$ & 33,8 & 40,0 \\
\hline
\end{tabular}

Waugh (1977), estudando o efeito de desfolhantes químicos ou herbicidas em Eucalyptus regnans nas tensões residuais liberadas no desdobro das toras, verificou que houve uma redução nas tensões de crescimento longitudinais da ordem de $20 \% \pm 15 \%$, após 12 meses de tratamento, em relação às testemunhas.

\subsection{Sistema de desdobro}

O desdobro consiste em converter as toras de madeira de forma cilíndrica, em tábuas, pranchas e vigas de secções retangulares ou quadradas nas mais variadas bitolas e medidas.

Andrade (1961), considera que o desdobro de árvores com idades mais avançadas, são de extrema importância para o êxito da utilização do eucalipto. $\mathrm{Na}$ Austrália, esta prática é corrente, onde se utilizam árvores com idades superiores a 25 anos para vigamentos, construções e dormentes. Em face dos dados atualmente disponíveis, recomenda-se para o Brasil a utilização de árvores de pelo menos 30 anos Galvão (1976).

/ Segundo Galvão (1976), o sucesso do eucalipto como material de serraria pode ser alcançado principiando-se pela utilização de espécies adequadas, de idade conveniente, cujas toras devem ser desdobradas de 
acordo com métodos que levem em consideração as características de sua madeira.

Galvão (1976) analisou os aspectos da utilização da madeira de eucalipto no Brasil, objetivando seu aproveitamento em serraria. As razões do insucesso de sua utilização para este fim são destacadas a seguir:

- Uso de espécies inadequadas, sendo o material usado, sem considerar as suas aptidões.

- Escassez de informações sobre o manejo de povoamentos para este fim, já que trabalhos publicados neste sentido são raros.

- Estudos genéticos que não consideram as propriedades e a qualidade da madeira como parâmetro importante nos programas de melhoramento.

- Escassez de pesquisas e informações tecnológicas, sendo as poucas existentes, obtidas no processamento empírico da madeira.

No Brasil, há a necessidade de desenvolvimento e mesmo de adaptações dos sistemas de serrarias tradicionais, para que as espécies de rápido crescimento possam ser desdobradas com rendimento satisfatório, principalmente com relação às tensões de crescimento. Equipamentos adequados e técnicas próprias de desdobro, são sem dúvida alguma, um fator muito importante no bom aproveitamento das toras produzidas por espécie de rápido crescimento, como é o caso do eucalipto.

O desdobro apropriado é fator importante para o sucesso do rendimento e da utilização de madeiras do eucalipto. Conforme Galvão (1976), deve-se procurar obter a maior quantidade possivel de madeira radial, que tem menor possibilidade de apresentar defeitos de secagem por se movimentar menos. Entretanto, é uma prática ainda não usada em nosso meio, porque é um desdobro mais dispendioso por ser de menor produtividade, afetando o rendimento em madeira serrada em relação ao método de cortes paralelos ou toro desfiado. Contudo na Austrália, os métodos radiais são indicados e 
efetivamente utilizados no desdobro de madeira de eucalipto. O menor rendimento e produção são largamente compensados por uma redução de defeitos das peças obtidas, melhor aproveitamento e comportamento em uso. As peças radiais apresentam as seguintes vantagens sobre as tangenciais menor instabilidade na largura, menores possibilidades de aparecimento de defeitos na secagem e melhor recondicionamento, caso ocorra colapso.

Garcia (1995) afirma que estas peças apresentam uma flecha no seu plano de maior inércia e portanto, só será endireitada mediante desgastes, o que ocasionará evidentemente, uma queda de produtividade. Entretanto, é uma peça recomendada para solicitações de flexão utilizando-se a flecha natural como contra flecha numa estrutura. No caso de solicitações de compressão é necessário compensar a excentricidade inicial com o aumento calculado das dimensões da peça.

O mesmo autor conclui que os cortes tangenciais sucessivos efetuados em serras de corte único não são do ponto de vista prático, indicados para produção de madeira serrada de espécies que tenham relativamente altas deformações de crescimento. Isto porque, após a retirada de cada tábua, o bloco remanescente se deforma por flexão, pela adaptação à nova distribuição residual, implicando na perda de uniformidade de espessura da próxima peça a ser serrada. No processo de desdobro, o mesmo autor afirma que no caso de cortes duplos, quádruplos ou múltiplos como aqueles produzidos pela serra de quadro cheio é preciso preocupar-se com a espessura mínima admissível da prancha diametral, para que não ocorram as prejudiciais rachaduras de extremidades.

Garcia (1995) conclui que peças de madeira desdobradas tangencialmente que apresentam curvamentos naturais, não são recomendadas para solicitação de compressão, como aquela que ocorre, pôr exemplo, no banzo superior de uma treliça, porque estaria somando uma excentricidade inicial ao problema da flambagem. Também não seria indicada 
para solicitações de flexão, como uma terça, porque trabalharia sob flexotorção.

A mesma peça acima, entretanto, devido à sua menor inércia pode ser retificada na secagem mediante a aplicação de cargas transversais, mas neste caso, guardará tensões residuais que poderão se manifestar por ocasião de cortes longitudinais posteriores. Recomenda então, que as suas dimensões sejam as mais próximas possiveis daquelas necessárias ao seu uso final.

Loehnertz et al. (1996) fizeram um levantamento da tecnologia de desdobro em cinco países tropicais: Brasil, Ghana, Indonésia, Malásia e Venezuela, concluíram que, os problemas mais comumente relacionados ao desdobro, incluem a manutenção deficiente das serras, falta de pessoal treinado, equipamento obsoleto, baixa resistência ao desgaste e geometria inadequada dos dentes de serra.

Num trabalho conduzido com Eucalyptus grandis (Montagna et al., 1991), compararou dois métodos de desdobro, concluiu que a retirada de duas costaneiras de espessura de cerca de 1/3 do raio, a partir da periferia da tora. Quanto ao desdobro, a expectativa é se possibilitava a obtenção de peças com baixos indices de rachaduras

O método acima foi comparado com o desdobro de cortes paralelos que consiste em fixar-se a tora e serra-la através de sucessivos cortes, sem rotacionar a tora. Este estudo mostrou que nas toras verdes, o indice de rachaduras em cortes paralelos foi nove vezes superior àquele obtido no sistema de cortes a 1/3 do raio em ambos os lados da tora.

Neste trabalho não há comentários sobre a ocorrência ou não de variação das espessuras das tábuas, uma vez que cortes paralelos seqüenciados e cortes a $1 / 3$ do raio, produzem peças de espessuras irregulares na madeira de eucalipto.

Chafe (1979) considera que a severidade dos problemas associados às tensões de crescimento encontrados na conversão de espécies arbóreas em 
produtos madeireiros pode variar consideravelmente de um indivíduo para outro. Assim, uma árvore pode não manifestar fendilhados após a derrubada, enquanto outra pode rachar explosivamente em vários segmentos. Da mesma forma, uma tora pode ser serrada com relativa facilidade e dar uma alta produção, enquanto uma outra pode se mover sobre a plataforma da serra, forçar a serra e/ou produzir uma alta proporção de material empenado ou fendilhado. Esta variação é vista tanto dentro como entre espécies.

As toras de menores idades, ou ainda jovens, racham com muita facilidade durante e após o desdobro. Segundo Galvão (1976), as árvores de Eucalyptus globulus, de diâmetros inferiores a $60 \mathrm{~cm}$, apresentam tensões internas responsáveis pelo aparecimento de fendas nas peças desdobradas. $\mathrm{Na}$ África do sul, o Eucalyptus grandis proveniente de desbastes tem sido utilizado desde a idade de 7-8 anos, com diâmetro superior a $18 \mathrm{~cm}$ (Ramos, 1973). O desdobro nesse caso, obedece a técnicas especiais, visando evitar o fendilhamento e o empenamento após o corte. O desdobro de toras de eucaliptos deve ser realizado através de cortes simétricos, visando liberar as tensões de crescimento de forma equilibrada, obtendo melhor qualidade das peças desdobradas. As toras não devem ter mais de 3 metros de comprimento, principalmente quando desdobrada em serra de fita simples. A largura da peça deve ser menor do que 6 polegadas, sendo que a largura ideal é de 4 polegadas.

Durante o desdobro, as toras devem estar bem centralizadas para haver liberação equilibrada das tensões de crescimento. A centralização das toras, que é realizada visualmente pelo operador da serra de fita é muitas vezes difícil. Se a tora não estiver bem centralizada, o corte não será simétrico e portanto haverá uma flexão do bloco devido à liberação de tensões de intensidades diferentes. Este problema originam os arqueamentos, quando esse bloco é resserrado na serra múltipla. 


\subsection{Rendimentos no desdobro}

O rendimento mede a relação entre o volume de madeira serrada ou desdobrada pelo volume de toras desdobradas. Segundo Mello (1978), nas serrarias que trabalham com coniferas o rendimento considerado normal é de 55 a $65 \%$ e no caso de folhosas é de 45 a $55 \%$. O rendimento mais elevado para as coníferas, se deve ao fato de apresentar tronco mais reto que as folhosas e terem alburno sempre mais aproveitável.

Em 24 serrarias, no Estado de Santa Catarina, foram verificados rendimentos em serra de fita, da ordem de $53,9 \%$ e em 25 serrarias que utilizavam serra de quadro Tissot, o rendimento foi da ordem de $53,2 \%$ (Mello, 1978).

Num ensaio de desdobro de toras de Eucalyptus saligna de 34 anos de idade e diâmetro médio de $63 \mathrm{~cm}$, Berengut et al. (1973) compararam quatro métodos de desdobro, obtendo como melhor resultado, a retirada sucessiva nas toras, em apenas 3 costaneiras sendo o bloco restante desdobrado em cortes paralelos e sucessivos. Este sistema apresentou as seguintes vantagens: neutralizou as tensões de crescimento pela diminuição das partes periféricas e possibilitou efetuar diversos cortes sem virar a tora.

Estudando o desdobro de toras de Eucalyptus saligna com 23 anos de idade de DAP médio de $34 \mathrm{~cm}$ e comprimento de $2,5 \mathrm{~m}$, Ghilardi4, citado por Miranda (1997), obteve um rendimento de $64 \%$ e um efeito das tensões de crescimento desprezível. $O$ método utilizado compreendeu um esquadrejamento das quatro faces da tora e em seguida o desdobro em serra de quadro vertical adaptada para retirar quatro tábuas por corte.

Freitas et al. (1993), obteve rendimentos variando de 42 a $50 \%$, dependendo da classe do diâmetro da tora, utilizando uma serra de fita geminada com bitolador automático, duas resserras de fita, duas refiladeiras 
múltiplas pneumáticas de um só eixo e uma serra circular múltipla de dois eixos para corte de até $20 \mathrm{~cm}$ de espessura, serrando madeiras de $E$. grandis e $E$. saligna. A produtividade expressa em $\mathrm{m}^{3}$ de madeira serrada produzida, dependeu fortemente do diâmetro da tora. Quando se passa de uma classe de diâmetro de $15,0-20,0 \mathrm{~cm}$ para $20,0-25,0 \mathrm{~cm}$, o aumento de produtividade é da ordem de $106 \%$. O método de desdobro utilizado no desdobro das toras, não foi especificado.

Leite (1994), constatou que no desdobro de um lote de toras em serraria, geralmente o rendimento é definido pelo valor do menor diâmetro, e calculado com base na área transversal equivalente a esse menor diâmetro. 0 rendimento em uma serraria é estreitamente relacionado com o comprimento da tora. É mencionado ainda que entre os fatores a serem considerados no desenvolvimento de programação matemática, destacam-se os seguintes: diâmetro mínimo e máximo da tora, comprimento da tora, qualidade da tora, defeitos internos e externos.

Miranda (1997) estudou a influência do espaçamento de plantio de Eucalyptus saligna de 9 anos de idade, no rendimento em madeira serrada, nas condiçōes verde e seca, para um diâmetro médio da ponta mais fina da tora de $20,9 \mathrm{~cm}$. O rendimento em madeira serrada das toras na condição verde, variou de $19,64 \%$ a $59,11 \%$, apresentando uma média em torno de $41 \%$. Segundo o autor estes resultados foram considerados satisfatórios para os diâmetros do experimento.

\subsection{Percentagem de Alburno}

O alburno consiste na parte do lenho formado por células vivas e atuantes ou fisiologicamente ativas. Além da função resistente, o alburno é condutor de seiva bruta, por ascensão capilar desde as raizes até a copa. É

${ }^{4}$ GUILARDI, E. Desdobro de Eucalyptus saligna. São paulo, IPT, 1973. (Relatório Interno) 
também denominado de parte branca da madeira e representa, em algumas espécies, cerca de 25 a $50 \%$ do lenho (Franco, 1995).

Franco (1995), explica que o cerne é a parte do lenho formada por células mortas resultantes da diferenciação do alburno. Durante esta alteração, as paredes das células impregnam-se por taninos, resinas e materiais corantes que obstruem os vasos e conferem ao cerne uma cor mais escura que 0 alburno.

Ambas se apresentam de forma circular e no caso do eucalipto, o cerne vai se tornando mais escuro, com o avançar da idade da árvore. Esse escurecimento é devido à lignificação das células e à impregnação por compostos cromóforos. As células do cerne quando sofrem esse processo deixam de desempenhar suas funções vitais no sentido da circulação da seiva. Além desse escurecimento o cerne torna-se mais duro e mais resistente que 0 alburno. A sua função após a lignificação das paredes de suas células, tornamse puramente e mecânicas, aumentando a capacidade de suporte da árvore.

Santini (1988), fazendo uma referência aos lenhos de cerne e alburno, afirmou que $o$ alburno se impregna com maior facilidade que 0 primeiro. $A$ menor permeabilidade do cerne, pode ser explicada, pelo menos em parte, pelas alterações anatômicas físicas e químicas que ocorrem quando da transformação do alburno em cerne. Este fenômeno é acompanhado pela morte das células parenquimáticas do alburno e do acúmulo gradual de resinas, gomas, óleos, taninos, etc., que conferem uma coloração característica ao cerne de muitas espécies. Estas substâncias, quando tóxicas aos agentes biológicos de deterioração, aumentam significativamente a durabilidade natural da madeira, dispensando, na maioria dos casos, o tratamento do cerne com produtos químicos. Por outro lado, dificilmente a secagem da madeira e no caso de madeira seca, podem obstruir total ou parcialmente os caminhos normais de condução, diminuindo notavelmente ou inibindo por completo a circulação de preservativos. 
Santini (1988) afirma ainda que em muitas espécies de folhosas, a permeabilidade do cerne pode ser afetada pelo desenvolvimento de tilos, os quais são expansões vesiculares das células parenquimáticas radiais ou axiais, que penetram na cavidade dos vasos através das pontuações existentes em suas paredes de contato. Nas madeiras em que se desenvolvem, as tiloses podem reduzir substancialmente a permeabilidade dos vasos. Quando associadas a gomas e outros materiais, podem provocar o fechamento definitivo dos vasos, impedindo a passagem de líquidos:

Segundo Oliveira (1997), a quantificação da relação cerne alburno do ponto de vista tecnológico é importante, pois dependendo da utilização que se queira dar à madeira, existe uma maior ou menor conveniência desta ou daquela espécie e nas proporções destes dois tipos de madeira, que ocorrem nos troncos de árvores.

Quanto à resistência natural da madeira, as espécies com maior percentagem de alburno, são menos resistentes ao ataque de organismos xilófagos, quando em contato com o solo. Segundo Oliveira (1997), FAO (1981) e Santini (1998), o cerne apresenta maior durabilidade natural, mas de menor permeabilidade à preservantes.

Franco (1995), fazendo uma referência ao cerne e alburno, com relação à resistência destes dois tipos de lenho, comenta que é comum pensar-se que $o$ cerne das madeiras é mais resistente que o alburno. Entretanto em termos de resistência e peso especifico, os dois se equivalem. As diferenças absolutas de resistência podem ser atribuídas principalmente às diferenças de massa. Em estudos relativo à densidade do lenho, o cerne tem-se mostrado mais denso que o alburno. 


\subsection{Quantidade de casca}

A casca é considerada um resíduo e nos processos industriais, geralmente é eliminada, enquanto que a madeira, segue algum processo de transformação como em serrarias, fábricas de celulose e papel e postes. A casca é geralmente utilizada na produção de energia, calor, pressão e condicionamento de tanques

A espessura, o modo de crescimento e o aspecto da casca variam muito de uma espécie para outra, permitindo em muitos casos, reconhecerem-se as árvores pela simples observação de sua casca.

Para algumas utilizações industriais, a presença de casca influencia diretamente no processo industrial e na qualidade do produto final, sendo necessário a sua eliminação enquanto que para outros fins, a casca é indiferente e representa custos de transportes e remoção.

Para Busnardo et al.(1983), a casca vem ganhando importância cada vez maior em nosso país, como resíduo florestal energético. A casca é capaz de gerar energia a custos compativeis, mas vem sendo descartada na maioria das explorações florestais, porém é cada vez maior o interesse por seu uso. Já existem diversas caldeiras de vapor alimentadas exclusivamente por casca de Eucaliptos ou Pinus.

A determinação da espessura da casca e sua variação ao longo do tronco é de grande importância, pois dependendo da espécie florestal, dos objetivos da produção e da forma de comercialização da madeira, é necessário descontar o volume de casca dos troncos. Por outro lado, algumas espécies como o Eucalyptus astringens, apresentam um teor de tanino na casca que justifica a sua exploração econômica, tomando-se a quantificação desta, fator de grande interesse comercial. (Scheneider, 1979).

A casca é para a árvore uma proteção natural que a protege das bruscas mudanças de temperatura, do sol, de impactos mecânicos, de ataques 
dos predadores de todos os gêneros, como bactérias, fungos, insetos, cogumelos, etc. Ela tem a função de impedir a evaporação, pelas camadas exteriores do tronco, onde circulam grandes quantidades de água. Geralmente apresenta-se delgada e lisa em árvores novas, evolui e engrossa todos os anos, de forma distinta consoante a cada espécie, Fischesser (1981).

Alfonso (1987) afirma que o gênero Eucalyptus, apresenta casca com grande variedade de forma e textura, quando observada externamente. Dessa forma, as espécies são comumente agrupadas de acordo com o tipo de casca, recebendo cada grupo uma denominação especial. Tem-se assim alguns grupos, tais como: "Stringybark" (casca fibrosa e filamentosa, persistente), "Ironbark" (casca rugosa, fortemente sulcada, endurecida), "Gum" (casca lisa e decídua ou caduca). Além destes tipos temos as cascas "transervae", "blackbutt", "tallowood", etc, Góes (1977).

De acordo com Lopes (2000), o efeito negativo da casca na produção de carvão vegetal, papel e celulose e madeira serrada é o inconveniente ocasionado pelo acúmulo de material residual nas fábricas e serrarias, que reflete em custos para sua eliminação e manejo. Portanto, tem sido alvo de estudos, tanto do ponto de vista quantitativo, quanto tecnológico, que visam minimizar o impacto de altas percentagens de casca na cadeia de produção. Dessa forma continua sendo um importante indicador de seleção de árvores superiores.

Em algumas empresas a casca é eliminada logo após o abate da árvore, antes do embarque das toras para a indústria. Além de eliminar os inconvenientes acima, auxilia como fonte suplementar na reciclagem de nutrientes e protege o solo contra os agentes erosivos.

Algumas espécies possuem quantidades de casca maior que outras. Pode-se afirmar, por exemplo, que o Eucalyptus alba possui cerca de $20 \%$ de casca, enquanto que o Eucalyptus saligna possui $15 \%$. 
A medição da casca pode ser feita em árvores abatidas ou em pé. Em árvores abatidas seccionadas, não há dificuldade em se medir o diâmetro com e sem casca através de uma régua graduada. Se ambos os diâmetros forem medidos, a espessura da casca é metade da diferença entre as duas medidas.

A espessura da casca varia ao longo do tronco. O mesmo ocorre entre árvores de mesma espécie. Um exemplo é apresentado por Heinsdijk e Soares (1962), que estudando plantações de coníferas no Brasil, concluiram que a espessura da casca da Araucaria angustifolia ou Pinheiro Brasileiro pode variar de 1,3 a 3,6 cm nas árvores de alturas superiores a $12 \mathrm{~m}$, e de 0,7 a 2,0 cm nas árvores cujas alturas não ultrapassam $12 \mathrm{~m}$.

\subsection{Conicidade da tora}

Para Grosser (1979), a conicidade muito acentuada de árvore ou uma tora, é considerada um defeito. Define a conicidade como a diminuição do diâmetro do tronco, da base para a copa da árvore.

Para Scolforo et al (1995), a forma de uma árvore, pode ser definida como o afilamento natural que ocorre da base para o topo, na maioria das espécies florestais. É também denominada conicidade ou 'taper', que na maioria das vezes é definida como a relação entre a diferença dos diâmetros das extremidades de uma tora, dividida pelo comprimento desta.

A conicidade ocorre mais pronunciadamente em árvores isoladas, ou naquelas situadas às margens de povoamentos. De um modo geral, os troncos são classificados como cônicos quando apresentam uma diminuição do seu diâmetro em mais de $1,0 \mathrm{~cm}$ por metro de comprimento, ou $3,0 \mathrm{~cm}$ por metro quando se considera a circunferência, Grosser (1979).

Segundo o mesmo autor, a conicidade muito acentuada do tronco será sempre vista como um defeito porque o aproveitamento e utịlização da madeira 
serão influenciados desfavoravelmente. Peças serradas obtidas de toras excessivamente cônicas apresentam tendência a baixas resistências mecânicas, especialmente a flexão.

Num estudo sobre a produtividade e rendimento em serraria, Sayagués (1999), definindo os fatores que afetam o rendimento em madeira serrada, escreve que as toras mais volumosas apresentam maior rendimento que as menores e toras com menor conicidade apresentam em média maior rendimento do que as toras de maior conicidade. A Corfo/infor, (1989), afirma que a conicidade afeta no rendimento. Quanto maior a conicidade menor a percentagem de madeira desdobrada.

A idade e a forma de condução do povoamento, com diferentes intensidades de desbaste, interferem no comprimento da copa da árvore que por sua vez interfere na forma do tronco. A forma do tronco está diretamente relacionada com o comprimento da copa da árvore, ou seja, quanto maior o comprimento da copa ao longo do tronco, maior é a tendência de aumento da conicidade.

De acordo com Smith et al.(1996), os desbastes pesados no início do desenvolvimento de um povoamento, podem provocar um aumento da conicidade do fuste. $O$ aumento da forma cônica após o desbaste representa um ajustamento às novas condições a que ficam expostas as árvores. A maior desvantagem do aumento da conicidade das árvores está relacionada à utilização do produto final. No caso de serem processadas em serrarias, haverá grande perda de madeira na forma de costaneira. $O$ excesso de conicidade pode também inviabilizar a utilização da árvore sob a forma de poste por impor limitações no seu comprimento. 


\subsection{Incidência de nós}

O nó é a parte do galho que permanece na peça serrada. Na origem os ramos apresentam perfeita continuidade com os tecidos lenhosos, alterando apenas a direção da grã na madeira e darão origem aos chamados nós vivos. Com o desenvolvimento da árvore muitos ramos acabam morrendo e quando não são eliminados na desrama natural ou artificial, são apenas circundados pelos tecidos lenhosos, incluindo a casca morta do ramo, e dão origem aos nós mortos ou soltos.

Os nós afetam a aparência, a direção da grã e as propriedades da madeira. Em uma árvore normal de Eucalyptus, o tamanho dos nós aumenta de acordo com a altura. Os nós menores estão na base e os nós com diâmetros maiores estão na parte superior do tronco.

Segundo Ponce (1994), o tamanho e quantidade de nós na madeira serrada dependem de sua posição na tora e das características da tora. As toras, por sua vez, dependem de fatores genéticos das árvores que lhe dão origem, do espaçamento entre árvores e do manejo a que foram submetidas. Os nós vivos quando pequenos em relação à secção da peça serrada, não prejudicam alguns usos, como em lambris, forros, paredes, móveis, miolos de compensados. Os nós mortos, dependendo de sua posição nas tábuas, têm a tendência a soltar-se quando a madeira é seca, desvalorizando-a para aqueles e outros usos, que exigem melhor acabamento. Em algumas espécies como no E. grandis, os nós estão associados com a exudação de resinas.

A existência de nós na madeira implica em desvios dos seus tecidos componentes e da grã, variação da massa específica, irregularidades nos anéis de crescimento e, com freqüência, descontinuidade entre o nó e a madeira circundante, resultando de maneira geral em diminuição da resistência da peça (Tsoumis, 1991). 
A maior parte das espécies do gênero Eucalyptus apresentam uma boa desrama natural, e esta é sensivelmente favorecida pela redução do espaçamento entre árvores. Mesmo assim a incidência de nós ainda é significativa.

Para as finalidades a que se tem destinados até hoje os plantios de Eucalyptus: lenha, carvão, celulose, fibra, e em certos segmentos da construção civil, a presença de nós não tem causado problemas de qualidade. Portanto os reflorestamentos tem sido manejados sem nenhuma preocupação com a eliminação dos galhos, dando origem a toras com abundância de nós. Os investimentos realizados nas podas das árvores destinadas à serraria são altamente compensadores, podendo propiciar a produção de toras para serraria em períodos relativamente curtos. O preço da madeira de coníferas sem nós no mercado internacional é cerca de duas vezes maior, do que madeira com nós.

Segundo Ahrens (1994), a poda ou desrama no gênero Pinus, é uma operação silvicultural imprescindivel, sempre que existir o objetivo de produzir madeira livre de nós, para processamento em serrarias ou laminadoras. Por outro lado, é de reconhecimento generalizado que esta operação, implica em investimentos elevados e cuja recuperação será efetivada apenas por ocasião do corte final, ao término da rotação.

Pela sua reconhecida importância e pela magnitude dos investimentos requeridos, a prática da poda deve receber a atenção necessária. A poda deve ser realizada o mais cedo possivel em talhões selecionados adequadamente, sincronizando com as diferentes operações de manejo e de desbastes.

Quando a madeira se destina a serraria, é recomendado a utilização de espaçamentos menores, para facilitar a autodesrama e consequentemente a diminuição da incidência de nós na madeira, tornando-a mais limpa.

O recurso da mão de obra em no Brasil é abundante mas, ao contrário, a oferta de madeira de boa qualidade de eucalipto é escassa. O custo operacional de desrama em reflorestamento em Pinus taeda, que não 
ultrapassa US $\$ 0,12$ por árvore, até uma altura de 6 metros na tora, tem sido altamente compensado pela valorização na madeira que possibilita um retorno superior ao investido.

De acordo com Assis (1999), o uso da desrama artificial promove vantagens adicionais, reduzindo a formação de bolsas de resina e a ocorrência da formação de podridão do cerne. Desse modo, o ideal seria integrar a desrama natural e artificial, selecionando-se plantios com ramos finos, com boa capacidade de desrama natural e complementando-se a limpeza do tronco pelo uso da prática de desrama artificial.

Nicolielo (1987) cita diversas razões para a realização de desramas no início do desenvolvimento do povoamento, dentre elas a maior facilidade de acesso ao interior do talhão, proteção contra o fogo de copa e madeira de qualidade superior para fins de desdobro e laminação. Em florestas integradas onde nos últimos desbastes já são produzidas toras para laminação e serraria, possibilita a obtenção de madeiras de qualidade tecnológica superior as quais serão seguramente melhor remuneradas.

A curto prazo a única solução é a intervenção com desrama artificial. A diminuição do espaçamento, para a redução do diâmetro do lenho juvenil, indicado por Oliveira (1997), ramos finos e fáceis de podar. Sendo assim, através desta medida silvicultural simples de reflorestamento, dois problemas significativos da madeira são amenizados.

Nos estágios iniciais de crescimento do reflorestamento, em certos lugares, é freqüente a necessidade de se fazer uma roçada que pode ser manual. O custo adicional para se fazer uma desrama artificial, é amenizado, tornando a operação ainda mais viável, com menores custos adicionais.

O rendimento das operaçōes de roçada e poda é de 680 árvores por dia/homem. Experimentos já concluídos, mostraram que a poda não prejudicou o crescimento da árvore e melhorou a qualidade da madeira para laminação. Os nós existentes só apareceram no cilindro central. 
A empresa Agrícola Procopiaki Ltda de Curitibanos/SC, inicia a poda em Pinus sp, aos 4 anos, apresentando um rendimento de 300 árvores/homem/ dia, num custo de poda de U\$ 0,024/árvore.

A reflorestadora Sincol Ltda de Caçador-SC, recomenda a $1^{\circ}$ poda aos 2 anos de idade, retirando $50 \%$ da copa das árvores de pinus destinadas para serraria e laminação.

A reflorestadora Irani Ltda/SC realiza a poda para madeira destinada a serraria desde os 3 anos de idade com serrote, permanecendo $30 \%$ de copa. Não fornece custos, mas o rendimento operacional no caso do Pinus elliottii é de 350 árvores/homem/ dia. Para o Pinus taeda 250 árvores/homem/dia e Pinus patula 200 árvores homem/dia.

De acordo com Otte (2001), os Nós soltos está entre os principais defeitos que estão presentes na madeira, e as perdas ocasionadas por este problema, correspondem a $4 \%$ do total do volume da madeira.

\subsection{Rachaduras}

O índice de rachaduras medido logo após o desdobro, na condição de madeira verde, é um dos métodos mais utilizados para se ter um conhecimento do nivel das tensões de crescimento existentes nas toras das árvores. Entretanto, este mesmo índice determinado com madeira desdobrada seca, permite observar-se a interação das tensões de crescimento.

Para Garcia (1992), o índice de rachaduras de extremidades de tábua logo após o desdobro, também não indicam o total das tensões de crescimento existente nas toras em função da existência das tensões residuais que continuam armazenadas nas peças desdobradas. No entanto, é o método que melhor reflete a intensidade da tensão de crescimento, sem a presença das tensões de secagem. 
Lima (2000) observou que as rachaduras de topo de tábua diferenciaram significativamente, nas diferentes posições da árvore. $O$ autor observou que nas toras correspondentes à meia altura comercial, os valores de rachaduras foram maiores e na posição base foram menores. No topo e à meia altura os resultados são estatisticamente semelhantes, entretanto racharam mais do que na base.

O mesmo autor, concluiu que as diferentes intensidades de desbastes efetuadas através do método CCT não influenciaram significativamente as rachaduras de peças serradas úmidas. Como esses índices refletem os efeitos das tensões de crescimento existentes nas árvores de uma mesma classe de DAP, presume-se desta idéia que neste presente estudo, embora se utilizando de um grande número de espécies, as rachaduras não foram influenciadas por diferentes intensidades de desbastes executados nas áreas das espécies, uma vez que em todos os povoamentos já tinha sido feito, pelo menos um desbaste.

De acordo com Malan (1995), as tensões de crescimento provocam rachaduras severas nas extremidades das tábuas. A avaliação dos niveis de tensão usando-se o índice de rachaduras como medida indireta consome muito tempo, é destrutivo e pouco útil em material jovem. Além disso, a medida de rachaduras de extremidades é somente uma medida indireta dos niveis de tensão e poderia ser afetada por outros fatores além das tensões de crescimento, como por exemplo, a capacidade inerente das árvores de resistirem às rachaduras.

Mas, a medida direta das tensões na árvore, é um processo oneroso e não praticável para pequenas e médias indústrias. Assim as rachaduras e empenamentos ocorridos nas peças desdobradas, são ainda os melhores indicadores dos níveis de tensões. Mesmo sendo indicadores indiretos das tensões, as rachaduras e os encurvamentos das tábuas ou pranchas, são manifestações práticas e concretas do comportamento da espécie durante e após o desdobro das toras. 
Otte (2001) num estudo de oportunidades de mercado nacional e internacional de madeira serrada de eucalipto e considerando a grandeza dos custos de produção, classificou as rachaduras de extremidade de tábua, como o principal defeito, de todos os da madeira serrada de eucalipto. $\mathrm{Na}$ inspeção de recebimento essas rachaduras são bem visíveis e mensuráveis, ocasionando uma perda sobre o volume da madeira de $15 \%$. Segundo o mesmo autor, outro defeito de menor importância, mas também citado, é o encurvamento das tábuas, mas este problema pode ser corrigido durante o processo de industrialização.

\subsection{Encurvamentos (Flecha)}

O encurvamento é o mais freqüente tipo de empenamento que ocorre nas tábuas de Eucalyptus, após o desdobro das toras. Os outros empenamentos como arqueamento e encanoamento, pode ocorrer em função da técnica de desdobro utilizada, diâmetro da tora, largura da tábua e da secagem.

Estudando a variação de propriedades indicativas da tensão de crescimento em função na posição da árvore e da intensidade de desbaste em E. grandis de 18 anos de idade, de diâmetro médio de $30 \mathrm{~cm}$, Lima (2000), cita que o encurvamento é um dos tipos de empenamentos que ocorrem na madeira serrada de Eucalyptus. É definido como a curvatura que ocorre ao longo do comprimento da peça de madeira, medida num plano perpendicular à face. É também conhecido como empenamento longitudinal da face. Segundo o mesmo autor, os encurvamentos das peças serradas obtidos, apresentaram diferenças significativas entre toras. As toras de posições mais altas na árvore, fornecem peças que se encurvaram mais do que a quelas de posições inferires.

Segundo o mesmo autor os encurvamentos e rachaduras, são variáveis consideradas como indicadoras de tensão, e verificou que houve uma pequena 
influência da intensidade de desbaste no nível de tensões de crescimento no $E$. grandis. Existe uma tendência das tensões de crescimento serem mais influenciadas por fatores genéticos ou de sofrerem mais influência de outras práticas silviculturais.

O encurvamento é um defeito que ocorre com maior freqüência e intensidade nas espécies de eucaliptos, quando comparadas com outras madeiras de uso tradicional. Entretanto este defeito não determina a inutilização do material desdobrado. Embora indesejável, este defeito pode ser reduzido significativamente numa secagem adequada, pela redução do comprimento da peça ou pela fixação forçada da peça quando do seu uso.

O encanoamento não é um problema ligado diretamente às tensões de crescimento e sim da diferenciação entre as contrações de secagem que ocorrem em ambas as faces da tábua, na direção transversal.

$O$ arqueamento é conseqüência do diferencial de contrações de tração e compressão na direção longitudinal devido às tensões de crescimento. $O$ arqueamento é controlado de acordo com o sistema de desdobro utilizado.

No gênero Eucalyptus, os encurvamentos estão associados às tensões de crescimento, que resultam na diferença de contração longitudinal entre as duas faces opostas de uma tábua, além de possíveis desvios da grã (Garcia, 1995; Oliveira, 1992).

\subsection{Dureza (Janka)}

A dureza é uma característica que pode constituir-se em fator limitante para o emprego da madeira em pisos, movelaria e construção civil. $\dot{E}$ um indicativo importante da trabalhabilidade da madeira e ainda do comportamento dessa em assoalhos, parquetes, tacos, etc. A dureza correlaciona-se positivamente com a densidade básica da madeira (Calori, et al, 1997). 
A dureza é uma propriedade mecânica que permite medir a resistência da madeira à penetração de ferramentas e dá uma idéia de sua resistência ao desgaste Franco (1995). O mesmo autor, baseando-se na "British Standard" Bs373:1957, salienta que a caracterização da resistência da dureza é apropriada quando da utilização de uma madeira desconhecida para os seguintes usos: aparelhos de esporte, bolas para jogos, pranchado, entalhes, assoalhos, malhos e massetes, madeiras para prego, blocos de pavimentação, lápis, roletes e calandras, pulins, lançadeiras e para cunhas e cavilhas.

A SUDAMIPT, estudando o grupamento de espécies tropicais da Amazônia por similaridade de características básicas e por utilização, estabeleceu cinco classes de acordo com a Tabela 2.

Tabela 2. Classificação da Dureza da madeira de acordo com a SUDAM/IPT (1981).

\begin{tabular}{lc}
\hline \multicolumn{1}{c}{ Classe } & Dureza Janka MPa \\
\hline Muito baixa & $<10$ \\
Baixa & $10,1-40$ \\
Média & $40,1-90$ \\
Alta & $90,1-140$ \\
Muito alta & $>140,1$ \\
\hline
\end{tabular}

Nesse estudo da SUDAM/IPT, a dureza da madeira variou de $35 \mathrm{MPa}$ em Ceiba pentandra até $245 \mathrm{MPa}$ em Dialium guianense, ou seja a resistência variou de baixa à muito alta. De acordo com esse estudo a maioria das espécies da Amazônia estudadas foram classificadas como de dureza alta a muito alta.

Calori \& Kikuti (1997), estudando as propriedades físicas e mecânicas da madeira de Eucalyptus dunnii, aos 20 anos de idade, obteve uma a dureza média da madeira, na direção normal as fibras de $54 \mathrm{MPa}$, nas posições da base, meio e topo da árvore. 
Helmeister (1992), estudando as características físicas e mecânicas da madeira de 16 espécies de eucalipto à umidade de $12 \%$ encontrou para a dureza normal e paralela as fibras os valores da Tabela 3.

Tabela 3. Classificação da Dureza da madeira em oito espécies de Eucalipto.

\begin{tabular}{lccc}
\hline Espécie & $\begin{array}{c}\text { Dureza Normal } \\
\mathrm{MPa}\end{array}$ & $\begin{array}{c}\text { Dureza Paralela } \\
\mathrm{MPa}\end{array}$ & Classe \\
\hline E. microcorys & 92 & 80 & Média \\
E. propinqua & 86 & 94 & Alta \\
E. paniculata & 128 & 133 & Alta \\
E. citriodora & 108 & 99 & Alta \\
E. grandis & 48 & 41 & Média \\
E. tereticornis & 99 & 91 & Alta \\
E. urophylla & 86 & 57 & Média \\
E. saligna & 56 & 63 & Média \\
E. cloeziana & 87 & 63 & Média \\
\hline
\end{tabular}

Verifica-se na Tabela 3 que, de acordo com a classificação da SUDAM/IPT (1981), a maioria dos eucaliptos se enquadram na classes média e alta, e raramente ocupam a classe muito alta.

\subsection{Aparência da madeira}

Os eucaliptos apresentam grande variedade de cores entre espécies e mesmo em cada individuo. Geralmente a cor é uma caracteristica secundária e desconsiderada nos programas de melhoramento genético. A madeira de cores mais escuras geralmente são mais resistentes e pesadas do que as claras e de maior durabilidade ao apodrecimento. Quanto à preferência do mercado não existe um estudo especifico, mas no Brasil existe uma maior procura por móveis e pisos de coloração avermelhada (Oliveira, 1999) e na Europa por madeiras mais claras (Assis, 1999). 
De acordo com Kramer e Kozlowski (1979)5, citado por Oliveira (1997), uma ampla variedade de substâncias extrativas, incluindo taninos, diversas substâncias corantes, óleos, gomas, resinas e sais de ácidos orgânicos, são acumulados nos lúmens das paredes celulares durante a formação do cerne, resultando na cor escura da madeira. Estas substâncias também ocorrem no alburno, mas em menores quantidades, o que resulta na coloração mais clara.

De acordo com Assis (1999), a cor do lenho não é encarada como um problema no contexto da obtenção de produtos sólidos da madeira. Entretanto, pelas variações de gostos, costumes e até mesmo por modismos, a produção de madeira com determinadas cores poderá vir a se tornar uma oportunidade de mercado. A coloração da madeira pode ser um fator importante quando sua produção se destina à fabricação de móveis e peças de interiores.

As alterações da cor da madeira quando não protegida por tintas ou vernizes é normal durante o processo envelhecimento da madeira. De acordo com Grosser (1979), após o abate, a madeira, na região do corte, fica exposta ao oxigênio do ar. Segue-se, então, uma pós-coloração oxidativa dos elementos componentes da madeira. $O$ escurecimento não deve ser confundido com mancha de madeira, que existe no caso de ataque de fungos ou exudação de resinas.

De acordo com Assis (1999), a cor da madeira é influenciada pelo ambiente e existem grandes variações tanto entre espécies como entre indivíduos. Mesmo clones em mesmas condições de ambiente apresentam madeiras de coloração variada, indo desde o vermelho escuro até o claro. Pelas alteraçóes que são produzidas, ao se cruzarem espécies de madeira de colorações distintas, pode-se esperar o aparecimento de árvores com as mais diversas tendência de cores e, principalmente, que essa alterações de cores e tonalidades possam ser programadas com base nas cores que cada espécie possui.

${ }^{5}$ Kramer, P.J.; Kozlowwski, T.T. Physiology of wood plants. New York, Academic Press, 1979. 
O mesmo autor ainda garante que várias espécies podem ser utilizadas em cruzamentos visando a produção de madeira avermelhada, dentre elas o $E$. pellita, E. robusta, E. resinifera, E. urophylla, E. tereticornis e o E. saligna de coloração tendendo para o róseo. Como o ambiente exerce influência na expressão da cor, variações ambientais podem promover a migração de espécies entre grupos semelhantes.

Com relação às espécies de coloração castanha e que podem ser utilizadas em cruzamentos encontram-se o $E$. torelliana e o $E$. citriodora.

A qualidade da madeira de eucalipto já está mais do que comprovada há muito tempo. Conforme Oliveira (1999), desde longa data utiliza-se esta madeira nos Estados Unidos, especificamente na Califórnia, onde a espécie, por apresentar aparência avermelhada, recebe o nome de mogno australiano.

Em seu estudo de caracterização da madeira de sete espécies de eucaliptos para a construção civil, Oliveira (1999), comenta que na coloração do alburno no fuste recém abatido, existe um predominio da cor amarelo palha, que é comum na maioria das plantas produtoras de madeira. Quanto à coloração do cerne, nas mesmas condições anteriormente citadas, poderam ser notadas variações dependentes da espécie. Apresentaram cerne com tonalidades castanho claro a escuro nas espécies de $E$. citriodora, E. pilularis e E. cloeziana. As demais espécies apresentaram cerne de coloração variando do vermelho escuro, como o $E$. tereticornis e $E$. paniculata, ao rosado mais claro em $E$. urophylla e mais escuro em $E$. grandis

Atualmente existe uma busca de madeiras que possuam cor avermelhada, como substitutas do mogno. O gênero Eucalyptus tem apresentado resultados excelentes, porém de acordo com Oliveira (1999), apresenta obstáculos como a disponibilidade de madeira de qualidade e a continuidade do suprimento. 


\section{MATERIAL E MÉTODOS}

As parcelas de Eucalyptus utilizadas para este estudo foram efetivadas em talhões localizados na Estação Experimental de Anhembi, do Departamento de Ciências Florestais da ESALQ/USP, situada na margem esquerda do Rio Tietê, no município de Anhembi/SP.

As características geográficas, topográficas, edáficas e climáticas dessa estação, segundo Ferreira et al.(1993), são as seguintes:

* Latitude: $22^{\circ} 52^{\prime} \mathrm{S}$;

* Longitude: $48^{\circ} 06^{\prime} \mathrm{W}$;

* Altitude: $500 \mathrm{~m}$

* Relevo: plano a suavemente ondulado;

* Solo: podzólico, arenoso e profundo;

* Clima: Cwa, com veröes quentes e chuvosos e invernos moderadamente frios e secos. A ocorrência de geadas é rara. O período de chuva se estende de outubro a março, com período seco de abril a setembro. A passagem de um período para outro se dá abruptamente.

* Temperatura média anual: $21,0^{\circ} \mathrm{C}$;

* Temperatura média do mês mais frio: $17,1^{\circ} \mathrm{C}$;

* Temperatura média do mês mais quente: $23,7^{\circ} \mathrm{C}$;

* Precipitação média anual: $1.350 \mathrm{~mm}$;

* Déficit hídrico anual: $20 \mathrm{~mm}$.

As madeiras utilizadas no presente estudo foram provenientes de árvores selecionadas de 15 espécies de eucaliptos, as quais estão detalhadas na Tabela 4. 
As árvores foram produzidas a partir de sementes, em parcelas experimentais de aproximadamente 1 ha. Dentro de cada parcela foram abatidas 3 árvores por espécie, nas classes superiores de diâmetro.

A coluna do incremento médio anual dos diâmetros (IMA DAP), mostra a taxa de crescimento, aproximado, dos povoamentos. Embora tenha sido realizado um inventário dessas parcelas, os dados não podem ser considerados como exatos, por serem obtidos de talhões que foram submetidos a diferentes intensidades de desbastes.

Tabela 4. Características do material estudado.

\begin{tabular}{clcccc}
\hline Subgênero & Espécie & $\begin{array}{c}\text { Época plantio } \\
\text { Espaçamento }(\mathrm{m})\end{array}$ & $\begin{array}{c}\text { Idade } \\
\text { (anos) }\end{array}$ & $\begin{array}{c}\text { IMA } \\
\left(\mathrm{m}^{3} / \mathrm{ha} / \mathrm{ano}\right)\end{array}$ & $\begin{array}{c}\text { IMA DAP } \\
\text { (cm/ano) }\end{array}$ \\
\hline \multirow{5}{*}{ Symphyomyrtus } & E. microcorys & $21 / 6 / 82-3 \times 3$ & 17 & 35,1 & 1,75 \\
& E. paniculata & $20 / 8 / 79-3 \times 3$ & 20 & 26,0 & 1,29 \\
& E. pellita & $31 / 03 / 82-3 \times 3$ & 17 & 25,7 & 1,28 \\
& E. propinqua & $16 / 8 / 78-3 \times 2$ & 21 & 25,0 & 1,25 \\
& E. resinifera & $13 / 2 / 87-3 \times 3$ & 12 & 35,1 & 1,75 \\
& E. saligna & $20 / 1 / 76-3 \times 2$ & 23 & 28,0 & 1,39 \\
& E. tereticornis & $22 / 5 / 80-3 \times 3$ & 19 & 37,0 & 1,84 \\
& E. urophylla & $21 / 12 / 78-3 \times 3$ & 20 & 40,0 & 1,99 \\
& E. phaeotricha & $15 / 6 / 82-3 \times 3$ & 17 & 27,0 & 1,34 \\
Conymbialyptus & E. pilularis & $30 / 3 / 82-3 \times 2$ & 17 & 45,0 & 2,09 \\
& E. pyrocarpa & $15 / 6 / 82-3 \times 3$ & 17 & 41,5 & 2,03 \\
& E. citriodora & $22 / 5 / 80-3 \times 2$ & 17 & 38,0 & 1,90 \\
& E. maculata & $18 / 3 / 82-3 \times 2$ & 17 & 23,7 & 1,18 \\
& E. torelliana & $8 / 8 / 79-3 \times 2$ & 20 & 26,0 & 1,30 \\
& E. cloeziana & $22 / 5 / 80-3 \times 2$ & 17 & 38,0 & 1,89 \\
\hline
\end{tabular}

Inicialmente foi realizado um inventário em todas as áreas, onde se situam os plantios, medindo-se os DAPs. A partir desses dados, efetuaramse as distribuições de freqüências dos diâmetros medidos e optou-se pela classe de diâmetro compreendida pelos limites de 36 e $41 \mathrm{~cm}$, como aquela representativa de todas as populações em estudo. As árvores escolhidas 
foram as de melhor forma, mais cilíndrica, isentas de bifurcações, não inclinadas e localizadas no interior da parcela.

A operação de derrubada foi realizada com moto-serra, efetuandose um anelamento na tora antes do corte, situado $30 \mathrm{~cm}$ acima da posição do corte de abate. A profundidade aproximada do anelamento foi de $1 / 3$ do raio. Este método foi utilizado para minimizarem-se as rachaduras da secção basal do fuste, que geralmente ocorrem na derrubada da árvore. Depois da derrubada da árvore, procedeu-se um novo anelamento, a 7,20 $\mathrm{m}$ do anelamento da base. Esse procedimento está representado, esquematicamente, na Figura 3.

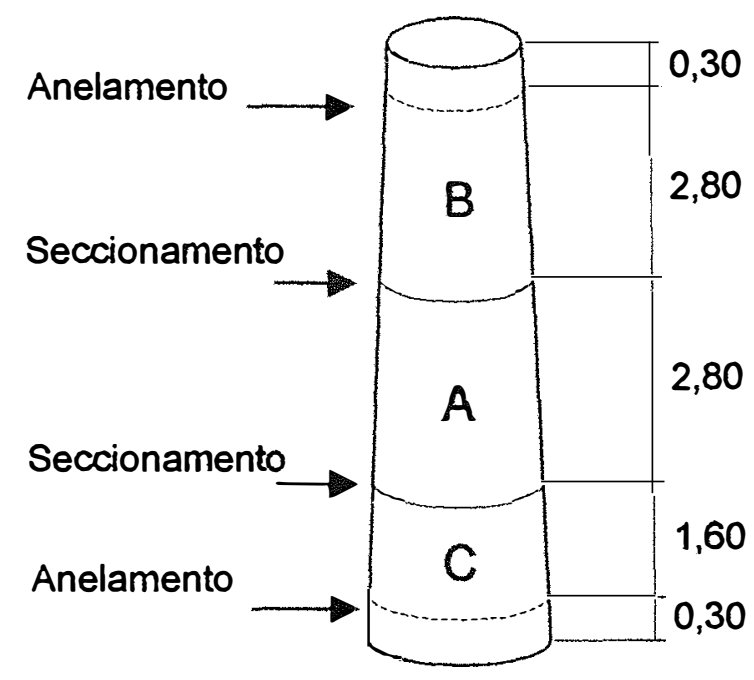

Figura 3 - Esquema de anelamentos e seccionamentos do fuste (medidas em $m$ ).

O anelamento também foi executado como sendo uma tentativa de evitar-se 0 avanço das rachaduras que surgem nas toras oriundas das tensões de crescimento elou de secagem. Nos devidos momentos foram feitas medições das seguintes variáveis: DAP com casca, circunferência com e sem casca em ambas as extremidades de cada tora, altura total do fuste e diâmetro do cerne. 


\subsection{Estocagem das toras}

O período compreendido entre a derrubada das árvores e o início do desdobro variou de 41 a 56 dias. Durante este período os fustes de 7,60 m permaneceram estocados no pátio da serraria, cobertos por sacos plásticos, e molhados a cada período de 2 dias para minimizarem-se os efeitos da secagem superficial nos topos das toras.

O seccionamento do fuste, conforme mostra a Figura 3, foi realizado no pátio da serraria. A tora " $C$ " de $1,60 \mathrm{~m}$, retirada na base do tronco, foi encaminhada ao laboratório de Painéis do próprio Departamento e as toras " $A$ " e " $B$ ", de 2,80 m de comprimento, foram utilizadas no presente trabalho. O seccionamento foi realizado no momento imediatamente anterior ao desdobro, seguindo-se o procedimento recomendado por Van Wyk (1978).

\subsection{Cubagem das toras}

Para a cubagem das toras utilizou-se a fórmula de Smallian, dada pela eq. (1). Nesta fórmula o volume de cada tora é calculado em função do comprimento e das áreas basais obtidas de suas extremidades.

$$
V t=\frac{\left(A_{1}+A_{2}\right)}{2} \times L
$$

onde:

$V t$ - volume da tora $\left(\mathrm{m}^{3}\right)$;

$A_{1}$ - área da seção da extremidade de maior diâmetro $\left(\mathrm{m}^{2}\right)$;

$A_{2}$ - área da seção da extremidade de menor diâmetro $\left(\mathrm{m}^{2}\right)$;

$L$ - Comprimento da tora considerada $(\mathrm{m})$.

\subsection{Quantificação da casca}

Para determinar a percentagem de casca existente em cada espécie, obtiveram-se os dados necessários em uma cubagem rigorosa de 
todas as toras realizando-se, em princípio, uma medida da circunferência com casca em cada extremidade de cada tora. Em seguida a tora foi descascada e feitas novas medidas, das respectivas circunferências da tora sem casca. A percentagem de casca, dada pela razão entre a área da secção transversal da tora com casca e a área transversal da tora sem casca, foi obtida, conforme descrito em Koch (1971), de acordo com a eq. (2).

$$
P C(\%)=\left(1-\frac{A s c}{A c c}\right) \times 100
$$

Onde:

PC - Percentagem de casca (\%);

Asc - Área da secção da tora sem casca $\left(\mathrm{cm}^{2}\right)$;

$A c c$ - Área da secção da tora com casca $\left(\mathrm{cm}^{2}\right)$.

\subsection{Percentagem de alburno}

A distinção entre cerne e alburno foi verificada através da diferença de cores nas secções transversais, quando do seccionamento das árvores em toras.

A percentagem de alburno, é dada pela razão entre a área da secção de alburno e a área da secção transversal da tora, sem casca, foi obtido pela eq. (3).

$$
P A(\%)=\left(1-\frac{A c}{A s c}\right) \times 100
$$

Onde:

$P A$ - Percentagem de Alburno (\%);

Ac. - Área da seç̧ão transversal de cerne $\left(\mathrm{cm}^{2}\right)$.

\subsection{Conicidade}

A conicidade representa o quanto o diâmetro de uma tora se reduz, a cada metro linear medido na direção do topo. Foi calculada pela relação 
entre a diferença dos diâmetro das extremidades da tora e o seu comprimento, como mostra a eq. 4.

$$
C=\frac{\left(D_{1}-D_{2}\right)}{L}
$$

Onde:

$C$ - Conicidade $(\mathrm{cm} / \mathrm{m})$;

$D_{1}$ - Diâmetro da base da tora $(\mathrm{cm})$;

$\mathrm{D}_{2}$ - Diâmetro do topo da tora $(\mathrm{cm})$;

$L$ - Comprimento da tora considerada $(m)$.

\subsection{Desdobro}

A madeira foi desdobrada na serraria do Departamento de Ciências Florestais da ESALQ/USP, em Piracicaba/SP, em uma serra de fita simples, de diâmetro de volante igual a $110 \mathrm{~mm}$, carro porta tora tipo semipesado, com velocidade de avanço de aproximadamente $7,5 \mathrm{~m} /$ minuto, espessura de corte de $3,0 \mathrm{~mm}$, largura da lâmina de $12 \mathrm{~cm}$ e comprimento da lâmina de $7,5 \mathrm{~m}$.

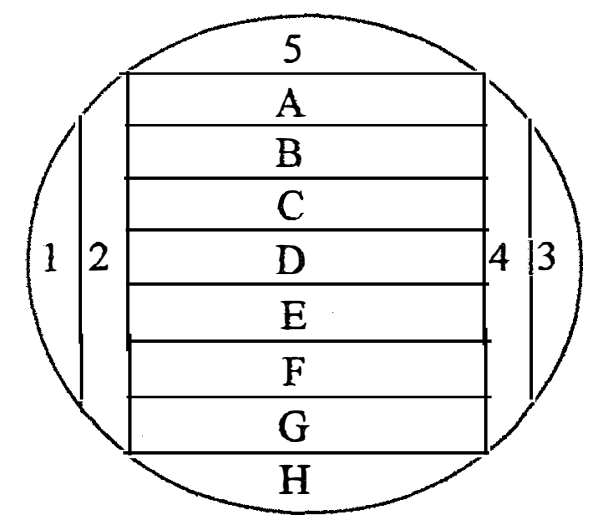

Figura 4 - Sistema de desdobro por cortes tangenciais semi-balanceados.

Foi utilizado o método de cortes tangenciais semi-balanceados, recomendado para pequenas serrarias, que processam 0 gênero Eucalyptus. Esta técnica de desdobro foi utilizada porque os métodos de 
cortes tradicionais, como o de cortes tangenciais sucessivos possibilitam grandes incidências de encurvamentos, desbitolamentos e de rachaduras nas extremidades das tábuas.

Rocha (1999) também cita este mesmo método de desdobro com o objetivo de diminuir a manifestação das tensões de crescimento. Para o autor, esse método é classificado como de cortes alternados, feitos em relação ao eixo longitudinal da tora. Depois de um ou dois cortes sucessivos em um mesmo lado da tora, esta é girada de $180^{\circ}$ seguindo-se um número igual de cortes no lado oposto.

No presente estudo os cortes sucessivos, de um mesmo lado da tora, foram feitos até atingir $1 / 3$ do raio. A seguir, o bloco remanescente foi girada de $90^{\circ}$ e desdobrado por cortes tangenciais sucessivos. A Figura 5 mostra o esquema de desdobro adotado.

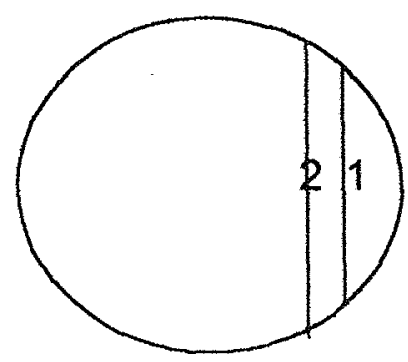

$180^{\circ}$

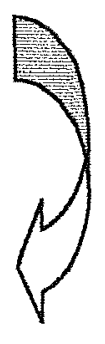

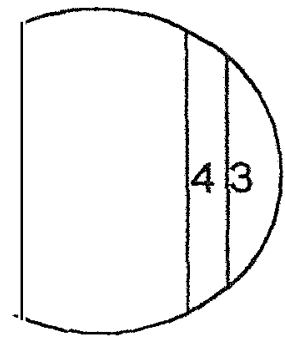

$90^{\circ}$

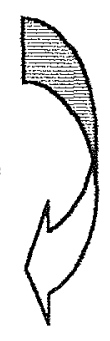

(b)

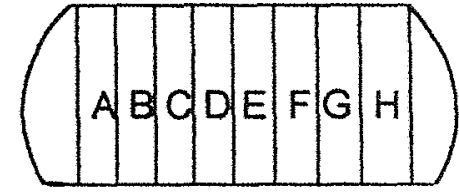

(c)

Figura 5 - Esquema da técnica de desdobro adotada.

Este método que também foi proposto por Sharma et al. (1988), é adaptado para o processamento do eucalipto em serras de fita simples. Com a retirada consecutiva das duas costaneiras da tora, ocorre uma liberação mais ou menos equilibrada de uma parcela da componente longitudinal da tensão de crescimento, que influi na redução das rachaduras das pranchas diametrais e desbitolamentos das tábuas tangenciais. 
Durante o desdobro, procedeu-se a identificação de cada tábua produzida, em relação à sua origem e posicionamento espacial no interior da tora, com a finalidade de estudar-se o comportamento global.

$\mathrm{Na}$ serraria foram medidos os seguintes parâmetros: dimensões das peças serradas, comprimento das rachaduras de extremidades das tábuas, flecha ou encurvamento e a incidência média de nós por face da tábua.

\subsection{Quantificação dos nós}

Com a finalidade de obter-se um parâmetro que pudesse quantificar a freqüência de nós por tábua, foi utilizado, simplesmente, o número de nós contados em ambas as faces da tábua, dividido por 2. Na análise estatística não foram diferenciados os nós firmes dos soltos. Todos eles foram considerados na mesma avaliação, numa única contagem. Não foram considerados os nós existentes nas bordas das tábuas.

Para obter-se a freqüência média de nós por tora, foi considerado o total de nós de todas as tábuas, dividido pelo número de tábuas obtidas dessa tora.

$$
I N=\frac{N^{\circ} N o}{2}
$$

Onde:

IN - Índice de Incidência de nós, por face da tábua serrada.

$N^{\circ}$ No - Número de nós em ambas as faces da peça.

\subsection{Rachaduras de extremidades das peças serradas}

O indice de rachadura das tábuas é considerado um indicativo do nivel de tensão residual existente na tora antes do desdobro. As rachaduras foram medidas logo após o desdobro e antes do processo de secagem, nunca ultrapassando um período de 48 horas. Foram calculados um indice 
para cada peça desdobrada (Figura 6) e uma média por tora, utilizando-se a eq. 6.

$$
\operatorname{IR}=C_{1}+C_{2}
$$

Onde:

IR - Indice de rachadura de extremidade de tábua;

$\mathrm{C}_{1}, \mathrm{C}_{2}=$ Comprimento da maior rachadura, respectivamente, na base $\mathrm{e}$ topo da tábua $(\mathrm{cm})$.

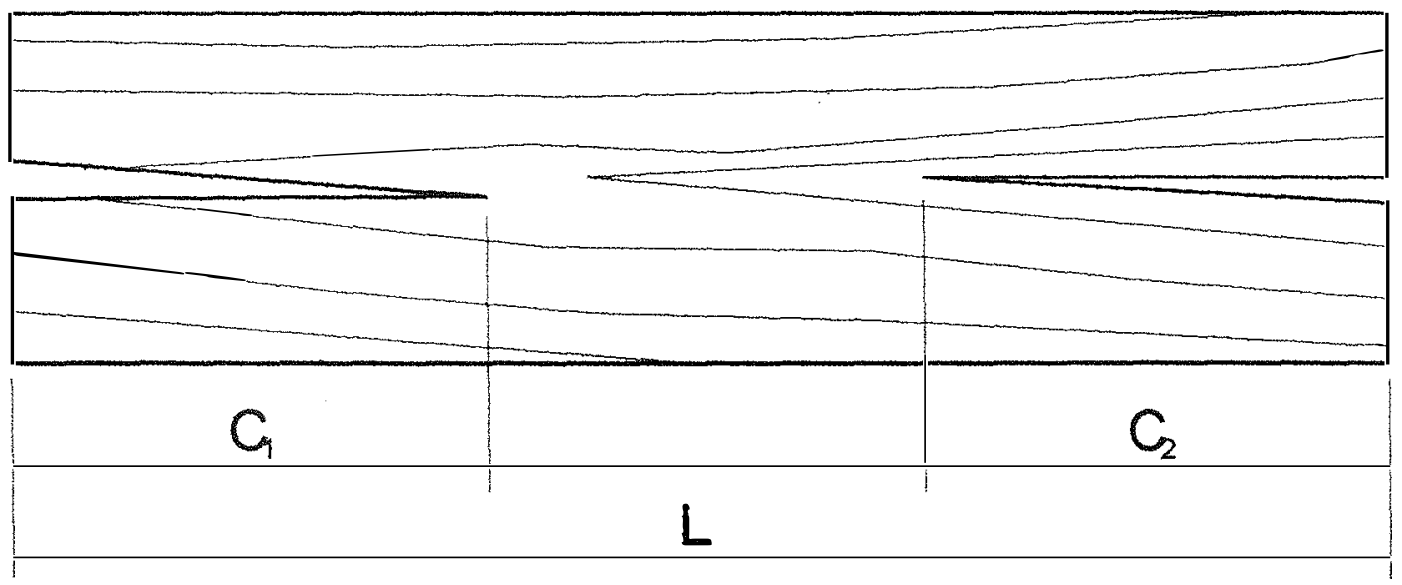

Figura 6 - Rachaduras de extremidades de tábua.

\subsection{Encurvamento (flecha)}

A flecha constitui-se num importante indicador de seleção de árvores para serraria, sendo considerado um bom indicador do nível de tensão de crescimento na árvore. De acordo com Garcia, 1995 é um parâmetro fácil e seguro de se avaliar as conseqüentes deformações oriundas destas tensões, num determinado processo de desdobro.

O encurvamento é um dos tipos de empenamentos que mais ocorrem na madeira serrada. É definido como a curvatura que ocorre ao longo do comprimento da peça desdobrada de madeira, medida num plano perpendicular à face.

Os encurvamentos das peças serradas foram medidos imediatamente após o.desdobro, conforme mostra a Figura 7. 


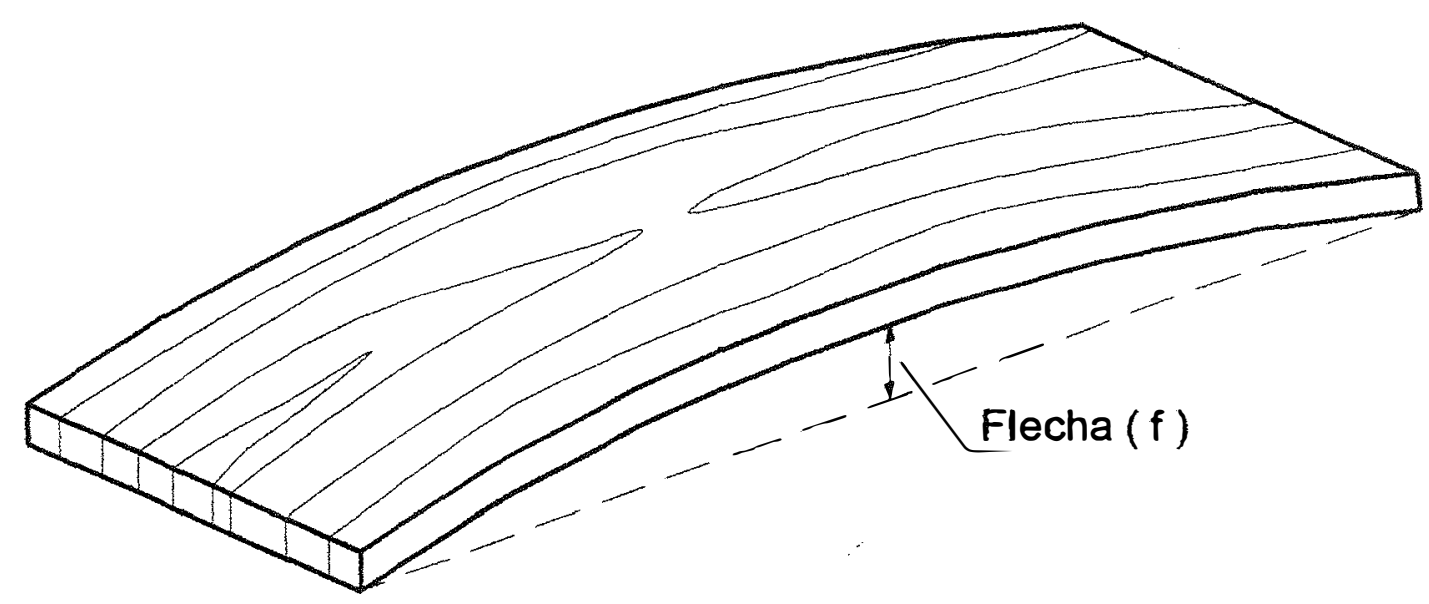

Figura 7 - Encurvamento da tábua.

\subsection{Rendimento em madeira serrada (RMS).}

$O$ rendimento em madeira serra da foi obtido pela equação 7 , sendo que no cálculo do volume de madeira desdobrada, os comprimentos das rachaduras de extremidades da peça serrada foram subtraídos do comprimento da tora. Foram também excluídos os esmoados das tábuas e pranchas. Obteve-se assim o comprimento útil da peça serrada.

$$
R M D=\frac{V d}{V_{T}} 100
$$

Onde:

RMS - rendimento em madeira serrada (\%);

$V d$ - volume de madeira desdobrada $\left(\mathrm{m}^{3}\right)$;

$V_{T}$ - volume da tora considerada $\left(\mathrm{m}^{3}\right)$.

\subsection{Estocagem da madeira serrada}

As quinze espécies de eucalipto foram submetidas a uma secagem por empacotamento, durante um período de um ano e cinco meses. A secagem por empacotamento consiste em envolver a pilha de madeira com Iona de fibra ou plástica, reduzindo significativamente a troca de umidade 
do interior da pilha para o ambiente externo. São deixadas apenas as aberturas na parte inferior da pilha e uma janela de ventilação na parte superior. A ventilação no interior da pilha de madeira era bastante suave e de sentido ascendente.

As tábuas foram empilhadas entrecruzadas, sem tabiques, de forma a forçar, pelo peso das camadas superiores 0 anelamento de seus encurvamentos.

Após 1 ano e 5 meses de secagem, todas as tábuas foram novamente medidas, para analisar-se a influência do armazenamento, no encurvamento.

\subsection{Dureza}

Este ensaio mede a resistência da madeira à penetração de uma esfera de aço, na direção desejada em relação às fibras. Dá uma idéia da resistência ao desgaste (Franco, 1995).

A Dureza é, numericamente, igual à força necessária para introduzir no corpo de prova da madeira, uma esfera de aço de $1 \mathrm{~cm}^{2}$ de secção projetada, até uma profundidade igual ao raio da esfera. A penetração da semi-esfera deve ocorrer num tempo mínimo de 1 minuto. Para os ensaios utilizou-se, no presente trabalho, apenas a direção normal às fibras para caracterização das espécies quanto à dureza.

As peças a serem ensaiadas foram escolhidas aleatoriamente do meio da pilha, dando-se preferência às tábuas localizadas próximas à medula e/ou as tangenciais, das quais foram confeccionados 5 tacos com tamanho de $8 \times 2,4 \times 24 \mathrm{~cm}$. 


\subsection{Delineamento estatístico}

Os resultados obtidos foram organizados na planilha eletrônica do Excel e as análises estatísticas foram efetuadas utilizando-se os recursos do programa SAS, importando-se os dados da planilha eletrônica.

Para a comparação entre médias de tratamentos, foi utilizado o teste de Bonferroni, aplicado ao nivel de $5 \%$ de probabilidade. Foi adotado este método de comparação por ser o mais indicado, quando se estuda um número superior a 8 tratamentos, Alves (2000).

A partir da formação do banco de dados e de sua subdivisão em vários arquivos correspondentes às características estudadas, foi possivel procederem-se as análises estatísticas, cujos resultados estão mostrados em tabelas apropriadas. Estas tabelas contêm as seguintes estatísticas:

- $\bar{X}$ : média dos valores das propriedades consideradas;

- Mínimo: valor mínimo encontrado;

- Máximo: valor máximo obtido

- s: desvio padrão dos valores numéricos da propriedade considerada;

- CV: coeficiente de variação;

- $S_{\mathbf{x}}^{-}$: erro padrão da média.

Para determinar-se um valor característico deve-se assumir que os resultados apresentem distribuição normal. Quando os resultados não apresentavam distribuição normal os mesmos valores eram transformados, antes da análise da variância. 


\subsection{Associação entre variáveis}

Foram analisadas, através do teste de correlação linear de interdependência proposto por Spearman, os pares entre rendimento e diâmetro das toras, rendimento e rachaduras, rendimento e conicidade, rendimento e encurvamentos, encurvamento e rachadura, rachadura e diâmetro, encurvamento e diâmetro.

De acordo com Beiguelman (1998), a interdependência de dois caracteres qualitativos, ou o grau de associação entre duas variáveis, é avaliada pelo coeficiente de associação e não pelo coeficiente de correlação

Para calcular o Coeficiente de Correlação ordinal de Spearman, foi utilizada a fórmula (8). Sua obtenção está baseada na ordem ou postos dos dados.

$$
\operatorname{CCS}=1-\frac{6 \sum_{i} d_{i}^{2}}{n\left(n^{2}-1\right)}
$$

Onde:

CCS - Coeficiente de correlação de postos;

n - Número de pares;

di - diferença entre os postos de xi e de yi. 


\section{RESULTADOS E DISCUSSÃO}

As características dendrométricas como diâmetro, altura, percentagem de alburno, nós, conicidade, percentagem de casca, encurvamentos, rachaduras das tábuas e rendimento em madeira serrada são características que qualificam o potencial da matéria prima lenhosa, para as mais variadas formas de utilização.

\subsection{Variação do diâmetro e altura das espécies de Eucalyptus}

Segundo Oliveira (1997), que comparou os valores de altura e diâmetro, alcançados por árvores de espécies nativas, o gen. Eucalyptus se destaca significativamente na produção de fustes de excelente forma e dimensões satisfatórias em período de tempo relativamente curto.

Nas condições climáticas do Brasil a idade ótima de abate das árvores para desdobro em serrarias é de 25 anos, aproximadamente,(Galvão, 1976), pois em idades inferiores as árvores estão ainda em plena atividade fisiológica e em pleno desenvolvimento, quando manejadas adequadamente.

No gênero Eucalyptus as toras de menores diâmetros além de produzirem maiores quantidades de resíduos, produzem tábuas com maiores percentagens de defeitos, advindas das tensões de crescimento, como empenamentos e rachaduras de extremidades. São mais recomendadas para produção de celulose, carvão, varas ou peças roliças para a construção civil e para o meio rural. 
A Tabela 5 apresenta algumas características dendrométricas das quinze espécies consideradas no presente estudo. $O$ diâmetro médio representa a média das pontas grossas e finas das toras "inferiores" e "superiores". A altura comercial representa a média dos comprimentos dos fustes medidos nas árvores derrubadas, até o diâmetro de $5 \mathrm{~cm}$. O restante da copa foi considerado não aproveitável comercialmente.

O diâmetro médio de todas as espécies foi de $33,53 \mathrm{~cm}$, destacando-se o Eucalyptus resinifera, que aos doze anos de idade, apresentou um diâmetro médio significativo. O DAP médio da parcela dessa espécie no campo foi de $26,53 \mathrm{~cm}$, inferior ao DAP das árvores abatidas para o presente trabalho mas mesmo assim, mostrou um crescimento considerável.

Tabela 5. Dados dendrométricos das quinze espécie de Eucalyptus.

\begin{tabular}{lccccccc}
\hline Espécie & $\begin{array}{c}\text { Altura } \\
\text { comercial } \\
(\mathrm{m})\end{array}$ & $\begin{array}{c}\text { Médio } \\
\mathrm{cm}\end{array}$ & $\begin{array}{c}\text { Diâmetro } \\
\text { Mínimo } \\
(\mathrm{cm})\end{array}$ & $\begin{array}{c}\text { Máximo } \\
(\mathrm{cm})\end{array}$ & $\mathbf{s}$ & $\begin{array}{c}\text { CV } \\
(\%)\end{array}$ & $\mathrm{S}_{\mathbf{x}}$ \\
\hline E. citriodora & 31,6 & 35,27 & 31,10 & 39,50 & 2,82 & 8,01 & 1,15 \\
E. cloeziana & 31,4 & 35,46 & 32,00 & 38,50 & 2,42 & 6,82 & 0,99 \\
E. maculata & 36,7 & 35,92 & 33,10 & 38,90 & 2,32 & 6,46 & 0,95 \\
E. microcorys & 32,0 & 30,90 & 27,35 & 36,00 & 3,20 & 10,36 & 1,30 \\
E. paniculata & 28,5 & 33,92 & 31,20 & 35,75 & 1,71 & 5,07 & 0,69 \\
E. pellita & 29,2 & 29,59 & 26,75 & 32,95 & 2,25 & 7,58 & 0,92 \\
E. phaeotricha & 25,4 & 32,92 & 29,75 & 37,10 & 1,24 & 3,73 & 1,23 \\
E. pilularis & 30,9 & 33,23 & 28,45 & 37,15 & 3,12 & 9,53 & 1,27 \\
E. propinqua & 26,0 & 32,51 & 29,25 & 35,30 & 2,41 & 7,47 & 0,98 \\
E. pyrocarpa & 31,5 & 34,86 & 31,20 & 37,80 & 2,62 & 7,51 & 1,07 \\
E. resinifera & 31,5 & 33,59 & 28,95 & 37,30 & 3,02 & 9,00 & 1,23 \\
E. saligna & 29,7 & 35,03 & 33,00 & 36,65 & 1,47 & 4,20 & 0,60 \\
E. tereticornis & 29,7 & 33,08 & 29,60 & 37,20 & 2,66 & 8,04 & 1,09 \\
E. torelliana & 24,4 & 32,67 & 27,65 & 38,25 & 3,90 & 12,00 & 1,59 \\
E. urophylla & 35,7 & 34,19 & 31,90 & 37,25 & 2,25 & 6,44 & 0,92 \\
\hline
\end{tabular}

$\mathbf{s}$ - Desvio padrão $\quad \mathrm{CV}=$ Coeficiente de variação $\quad \mathrm{S}_{\overline{\mathrm{x}}}$ - Erro Padrão da média

Essa tabela mostra que os diâmetros foram semelhantes para a maioria das espécies. Procurou-se dessa forma minimizar o efeito dessa variável. 
Com exceção do $E$. resinifera, cujas árvores foram abatidas aos 12,5 anos de idade e o E. saligna aos 23 anos, as demais espécies foram abatidas no intervalo entre 17 a 21 anos, apresentando maior freqüência na idade de 17 anos.

A Figura 8 mostra graficamente a relação entre a altura comercial média e o DAP médio das espécies de eucaliptos.

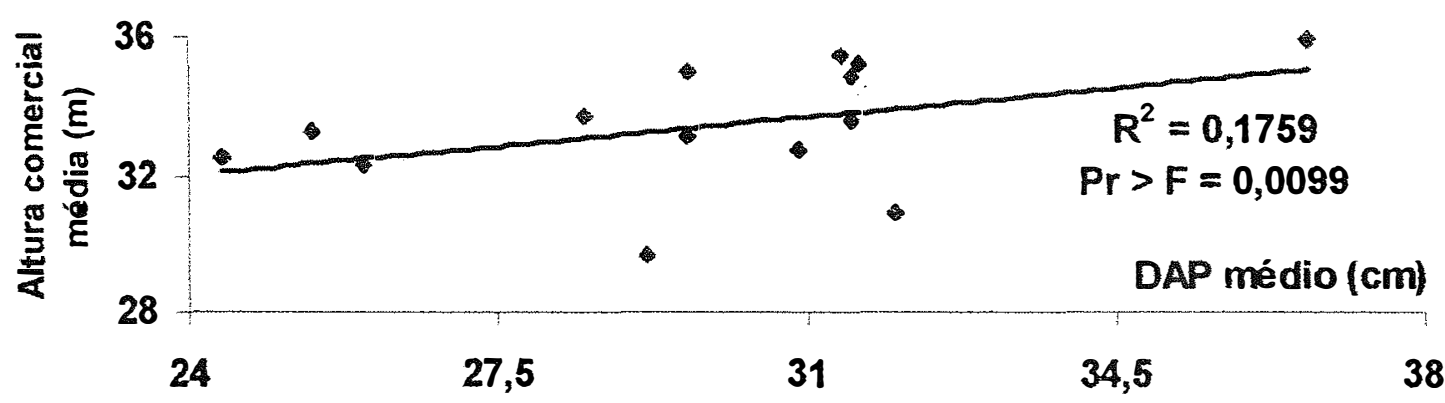

Figura 8 - Relação entre a altura comercial média e o DAP médio das árvores, de Eucalyptus.

Observa-se na Figura 8 que existe, para o conjunto das quinze espécies diferentes, uma correlação positiva entre a altura comercial média e o diâmetro médio das árvores. Entretanto o diâmetro responde por apenas $17,6 \%$ da altura da árvore.

Segundo Oliveira (1997) a altura total média das árvores podem ser consideradas como um índice de adaptabilidade da espécie, uma vez que pode ser utilizada como forma de avaliação do seu potencial genético, da qualidade do sítio, e de seu potencial de crescimento.

Os resultados da análise de variância aplicada aos diâmetros das toras, de todas as 15 espécies em estudo, encontram-se na Tabela 6.

Tabela 6. Análise de variância efetuada para a variável diâmetro.

\begin{tabular}{lcc}
\hline Causas de variação & GL & Pr $>F$ \\
\hline Espécie (E) & 14 & 0,0002 \\
Toras (T) & 1 & 0,0001 \\
EX T & 14 & 0,9996 \\
Residuo & 29 &
\end{tabular}


Observa-se na Tabela 6 que a análise de variância aplicada aos diâmetros mostrou diferenças significativas entre espécies e entre toras. Entretanto, não houve interação da espécie com a tora, significando que o padrão de redução de diâmetro da tora basal para a subsequente é o mesmo para todas as espécies.

Tabela 7. Comparação dos diâmetros médios das toras com casca.

\begin{tabular}{lcc}
\hline Causas de variação & Diâmetro médio (cc) & Grupo (1) \\
\hline E. maculata & 35,92 & $\mathrm{a}$ \\
E. cloeziana & 35,46 & $\mathrm{ab}$ \\
E. citriodora & 35,27 & $\mathrm{ab}$ \\
E. saligna & 35,03 & $\mathrm{ab}$ \\
E. pyrocarpa & 34,86 & $\mathrm{ab}$ \\
E. urophylla & 34,19 & $\mathrm{ab}$ \\
E. paniculata & 33,92 & $\mathrm{abc}$ \\
E. resinifera & 33,59 & $\mathrm{abc}$ \\
E. pilularis & 33,23 & $\mathrm{abc}$ \\
E. tereticornis & 33,08 & $\mathrm{abc}$ \\
E. phaeotricha & 32,92 & $\mathrm{abc}$ \\
E. torelliana & 32,67 & $\mathrm{abc}$ \\
E. propinqua & 32,51 & $\mathrm{abc}$ \\
E. microcorys & 30,90 & $\mathrm{bc}$ \\
E. pellita & 29,59 & $\mathrm{c}$
\end{tabular}

(1) Médias com a mesma letra não são significativamente diferentes entre si.

(2) $C V=7,23 \%$

O Eucalyptus maculata foi o que apresentou maior diâmetro médio das toras de $35,92 \mathrm{~cm}$, diferindo estatisticamente do $E$. microcorys e do $E$. pellita que apresentaram respectivamente 30,90 e $29,59 \mathrm{~cm}$. As demais espécies formam dois grupos intermediários, que apresentam um mesmo diâmetro médio. O primeiro grupo se assemelha ao E. maculata, e o segundo grupo se assemelha ao E. pellita. Portanto, apenas duas espécies apresentaram diâmetros diferentes entre si, embora tenha sido buscada a melhor homogeneidade possivel. As árvores escolhidas do E. resinifera, apresentam um diâmetro avantajado em relação das demais espécies, por ser cortada com 12 anos de idade. 
A Figura 9 apresenta graficamente os diametros médios das toras usadas no presente trabalho, das quinze espécies de eucalipto, agrupadas por subgêneros.

Symphyomyrtus Monocalyptus

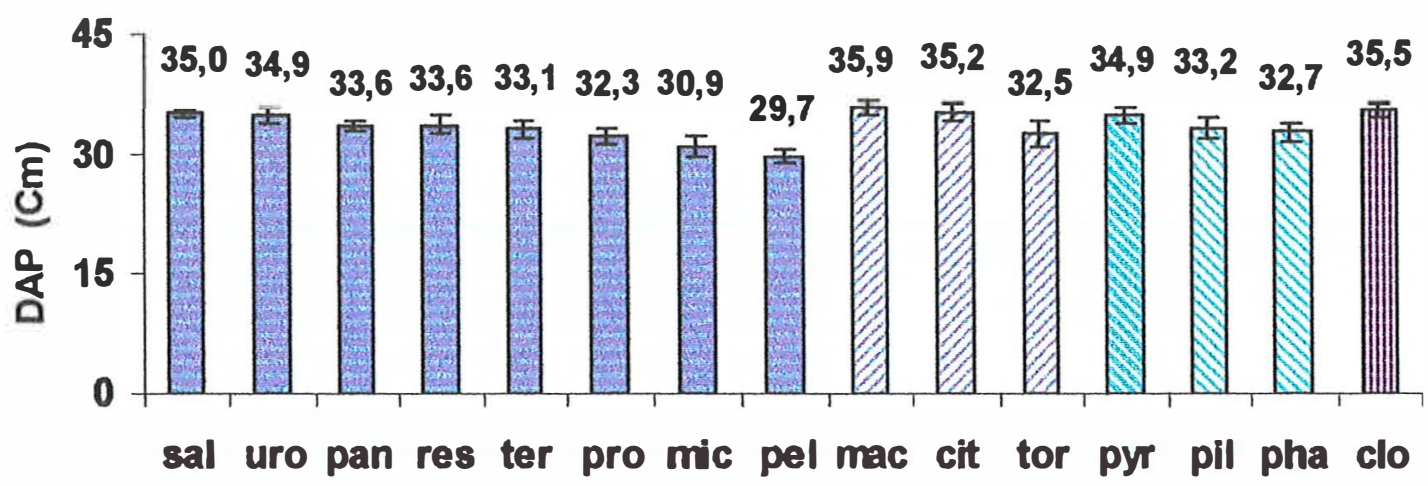

Figura 9 - Diâmetros médios das toras das 15 espécies de Eucalyptus, agrupadas em subgêneros.

Gomes (1963) afirma que o coeficiente de variação dá uma idéia da precisão do experimento. Tendo em vista os coeficientes de variação comumente obtidos nos ensaios agrícolas de campo, podem ser considerados baixos quando inferiores a 10\%, médios, quando entre 10 e $20 \%$ e altos, quando entre 20 e $30 \%$, e muito altos, quando superiores a $30 \%$. Entretanto, nem sempre o coeficiente de variação indica uma boa precisão experimental, uma vez que certas características analisadas na natureza, apresentam comportamento naturalmente aleatório. De qualquer maneira, um coeficiente de variação baixo é um bom indicativo, da precisão do experimento.

Portanto, o coeficiente de variação médio de $7,48 \%$, obtido no conjunto das quinze espécies de Eucalyptus, reflete a pouca variabilidade ou diferenciação entre os diâmetros usados no experimento. 


\subsection{Percentagem de alburno}

A proporção de alburno é uma característica da espécie e varia em função da idade, tipo de solo e clima, fertilização, espaçamento, taxa de crescimento e tratos culturais. No caso de madeira roliça tratada, o teor de alburno influi diretamente na absorção de produtos preservantes de madeira.

A Tabela 8 mostra a ocorrência de alburno em todas as espécies consideradas no presente trabalho.

Tabela 8. Percentagem de alburno nas quinze espécies de Eucalyptus.

\begin{tabular}{lcccccc}
\hline Espécie & $\begin{array}{c}\text { Média } \\
(\%)\end{array}$ & $\begin{array}{c}\text { Máximo } \\
(\%)\end{array}$ & $\begin{array}{c}\text { Mínimo } \\
(\%)\end{array}$ & s & C.V (\%). & $S_{\mathbf{x}}$ \\
\hline E. paniculata & 47,91 & 53,77 & 41,81 & 4,61 & 9,62 & 1,88 \\
E. toreliana & 46,51 & 59,23 & 28,30 & 11,76 & 25,28 & 4,80 \\
E. maculata & 45,38 & 51,90 & 37,42 & 6,00 & 13,22 & 2,45 \\
E. resinifera & 45,36 & 53,23 & 36,97 & 5,69 & 12,54 & 2,32 \\
E. citriodora & 43,35 & 48,26 & 34,14 & 5,32 & 12,27 & 2,17 \\
E. pellita & 43,18 & 48,35 & 39,09 & 3,53 & 8,17 & 1,44 \\
E. propinqua & 36,41 & 43,32 & 29,20 & 5,06 & 13,90 & 2,06 \\
E. microconys & 36,04 & 49,57 & 24,53 & 9,54 & 26,47 & 3,90 \\
E. tereticomis & 35,62 & 41,19 & 29,02 & 4,39 & 12,32 & 1,79 \\
E. phaeotricha & 32,59 & 37,66 & 22,54 & 5,31 & 16,29 & 2,17 \\
E. pilularis & 30,50 & 34,82 & 25,04 & 3,48 & 11,41 & 1,42 \\
E. saligna & 30,26 & 34,84 & 25,32 & 3,59 & 11,86 & 1,46 \\
E. cloeziana & 29,51 & 36,20 & 26,53 & 3,76 & 12,74 & 1,53 \\
E. urophylla & 29,08 & 40,14 & 22,07 & 6,61 & 22,73 & 2,70 \\
E. pyrocarpa & 26,43 & 28,89 & 23,90 & 2,07 & 7,83 & 0,85 \\
\hline S- Desvio padrăo & CV Coeficiente de variação & S- & Erro padrão da média &
\end{tabular}

A Tabela 8 deixa evidente a maior percentagem de alburno nas espécies de E. paniculata $(47,91 \%)$, E. toreliana $(46,51 \%)$, E. maculata $(45,38$ $\%)$, E. resinifera $(45,36 \%)$, E. citriodora $(43,35 \%)$ e o $E$. pellita $(43,18 \%)$. Podem ser considerados como os maiores produtores de peças serradas mescladas de cerne e alburno e também os maiores consumidores de produtos preservantes. Entretanto, apresentarão uma maior secção transversal tratada. No outro extremo estão o $E$. pyrocarpa $(26,43 \%), E$. urophylla $(29,08 \%), E$. cloeziana $(29,51 \%)$, E. saligna $(30,26 \%)$, e o E. pilularis com $(30,50 \%)$, que 
apresentaram as menores espessuras de alburno. A Figura 10 apresenta a distribuição das percentagens de alburno, das 15 espécies de Eucalyptus.

Os resultados da Tabela 8 são corroborados por Franco (1995), que afirma que o alburno representa em torno de 25 a $50 \%$ do lenho. Tomazello Filho (1988), estudando o E. camaldulensis, afirma que a percentagem de alburno depende da taxa de crescimento da árvore. Em indivíduos de rápido crescimento encontrou $31 \%$ de alburno na posição basal da árvore e em indivíduos de crescimento lento a percentagem de alburno foi de apenas $16 \%$.

Symphyomyrtus Monocalyptus

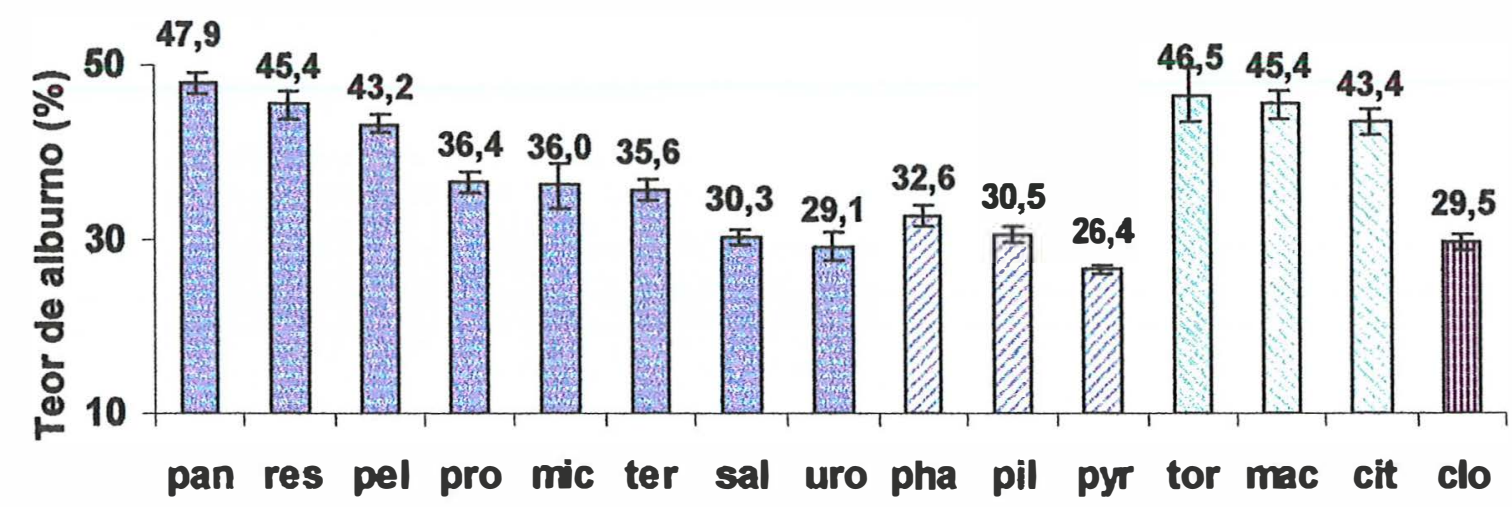

Figura 10 - Percentagem de Alburno das 15 espécies de Eucalyptus.

A Tabela 9 mostra que existem diferenças altamente significativas entre espécies e entre toras. Entretanto não houve interação entre as mesmas, significando que a variação da percentagem de alburno da primeira para a segunda tora, segue a mesma proporção em todas as espécies.

Tabela 9. Análise da variância aplicada às médias de percentagem de alburno nas quinze espécies de Eucalyptus.

\begin{tabular}{lcc}
\hline Causa de variação & GL & $\operatorname{Pr}>\mathrm{F}$ \\
\hline Espécie & 14 & 0,0001 \\
Toras & 1 & 0,0001 \\
Espécie X Tora & 14 & 0,9991 \\
Residuo & 29 & \\
\hline
\end{tabular}

$\mathrm{CV}=15,01 \%$

Tabela 10. Comparação da percentagem de alburno dos subgêneros de Eucalyptus. 
Tabela 10. Comparação da percentagem de alburno dos subgêneros de Eucalyptus.

\begin{tabular}{lcc}
\hline Causas de variação & (\%) de Alburno & Grupo (1) \\
\hline Corymbia & 45,08 & a \\
Symphyomyrtus & 37,98 & a \\
Monocalyptus & 29,84 & b \\
Idiogenes & 29,51 & b \\
\hline
\end{tabular}

CV $-18,90 \%$

A comparação de médias, pelo teste de Bonferroni ao nível de $5 \%$ de probabilidade, (Tabela 10), para a percentagem de alburno, revelou que existem diferenças significativas entre os subgêneros. O Corymbia e o Symphyomyrtus não diferem estatisticamente entre si, mas ambos diferem do Monocalyptus e Idiogenes, que também são semelhantes entre si.

Tabela 11. Comparação da percentagem de alburno, pelo teste de Bonferroni.

\begin{tabular}{|c|c|c|c|c|c|}
\hline Subgênero & Espécie & $\begin{array}{c}\text { Albumo } \\
(\%)\end{array}$ & $\begin{array}{l}\text { Espécies dentro } \\
\text { de subgênero (1) }\end{array}$ & \multicolumn{2}{|c|}{$\begin{array}{c}\text { Espécies dentro do } \\
\text { gênero (1) }\end{array}$} \\
\hline Symphyomyrtus & $\begin{array}{l}\text { E. paniculata } \\
\text { E. resinifera } \\
\text { E. pellita } \\
\text { E. propinqua } \\
\text { E. microcorys } \\
\text { E. Tereticomis } \\
\text { E. saligna } \\
\text { E. urophyila }\end{array}$ & $\begin{array}{l}47,91 \\
45,36 \\
43,18 \\
36,41 \\
36,04 \\
35,62 \\
30,26 \\
29,08\end{array}$ & $\begin{array}{l}\mathrm{a} \\
\mathrm{ba} \\
\mathrm{ba} \\
\mathrm{bc} \\
\mathrm{bc} \\
\mathrm{bc} \\
\mathrm{c} \\
\mathrm{c}\end{array}$ & $\begin{array}{l}\text { E. paniculata } \\
\text { E. torelliana } \\
\text { E. maculata } \\
\text { E. resinifera } \\
\text { E. citriodora } \\
\text { E. pellita } \\
\text { E. propinqua } \\
\text { E. microcorys }\end{array}$ & $\begin{array}{l}\text { a } \\
\text { ba } \\
\text { ba } \\
\text { ba } \\
\text { bac } \\
\text { bac } \\
\text { bdac } \\
\text { bdac }\end{array}$ \\
\hline Monocalyptus & $\begin{array}{l}\text { E. phaeotricha } \\
\text { E. pilularis } \\
\text { E. pyrocarpa }\end{array}$ & $\begin{array}{l}32,59 \\
30,50 \\
26,43\end{array}$ & $\begin{array}{c}a \\
a b \\
b\end{array}$ & $\begin{array}{l}\text { E. tereticomis } \\
\text { E. phaeotricha } \\
\text { E. pilularis }\end{array}$ & $\begin{array}{l}b d c \\
b d c \\
d\end{array}$ \\
\hline Corymbia & $\begin{array}{l}\text { E. torelliana } \\
\text { E. maculata } \\
\text { E. citriodora }\end{array}$ & $\begin{array}{l}46,51 \\
45,38 \\
43,35\end{array}$ & $\begin{array}{l}a \\
a \\
a\end{array}$ & $\begin{array}{l}\text { E. saligna } \\
\text { E. cloeziana } \\
\text { E. urophylla }\end{array}$ & $\begin{array}{l}d \\
d \\
d\end{array}$ \\
\hline Idiogenes & E. cloeziana & 29,51 & & E. pyrocarpa & $d$ \\
\hline
\end{tabular}

(1) Médias com a mesma letra não diferem significativamente entre si.

(2) $\mathrm{CV}=17,17 \%$

A Tabela 11 mostra que dentro do subgênero Symphyomyrtus existem diferenças significativas entre as espécies que se distribuem em três grupos distintos. O E. paniculata, E. resinifera e o E. pellita compõem o grupo que 
representam o grupo de menor percentagem de alburno. $O$ grupo do $E$. tereticornis, E. propinqua e E. microcorys apresentam valores que se assemelham estatisticamente aos dois outros grupos extremos.

Entre as espécies que compreendem o subgênero Corymbia não existem diferenças significativas. No subgênero Monocalyptus apenas o $E$. phaeotricha difere significativamente do E. pyrocarpa. O E. pilularis é semelhante aos outros dois grupos.

Verifica-se na figura 11, que nas quinze espécies de Eucalyptus a espessura do alburno variou de $2,3 \mathrm{~cm}$ até $4,4 \mathrm{~cm}$. Estes resultados são corroborados por Alfonso ${ }^{6}$ citado por Oliveira (1997) que afirma que, no gênero Eucalyptus, a espessura de alburno varia de 1,5 a $4,5 \mathrm{~cm}$.

Symphyomyrtus

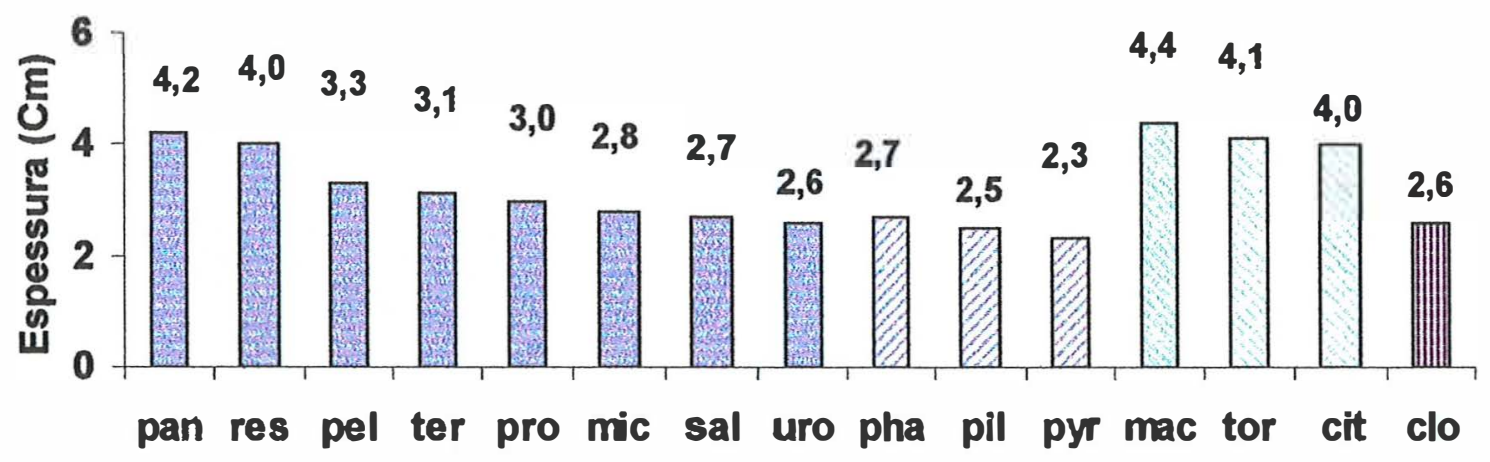

Figura 11 - Espessura do Alburno, em relação ao diâmetro da tora.

Oliveira (1997) observou que no fuste do E. paniculata, a proporção de alburno foi elevada, prevalecendo um valores acima de $60 \%$. A proporção de alburno também foi elevada no E. citriodora $48,40 \%$ e ligeiramente mais baixa nas espécies do E. pilularis $25,32 \%$, E. cloeziana $28,37 \%$, E tereticornis $32,40 \%$ e no E. urophylla $48,12 \%$.

\footnotetext{
${ }^{6}$ ALFONSO, V.A. Caracterização anatômica do lenho e da casca das principais espécies de Eucalyptus L'Herit. Cultivadas no Brasil. São Paulo, 1987. Tese (Doutorado) - Instituto de Biociências, Universidade de São Paulo.
} 
O mesmo autor também observou no gênero Eucalyptus, um aumento da percentagem de alburno ao longo da altura na árvore, chegando a ser 100 $\%$, na altura correspondente a $3 / 4$ da altura do fuste, para o $E$. paniculata.

A Figura 12 mostra que a percentagem de alburno aumenta com a altura, seguindo um padrão homogêneo de variação ao longo do tronco das árvores.
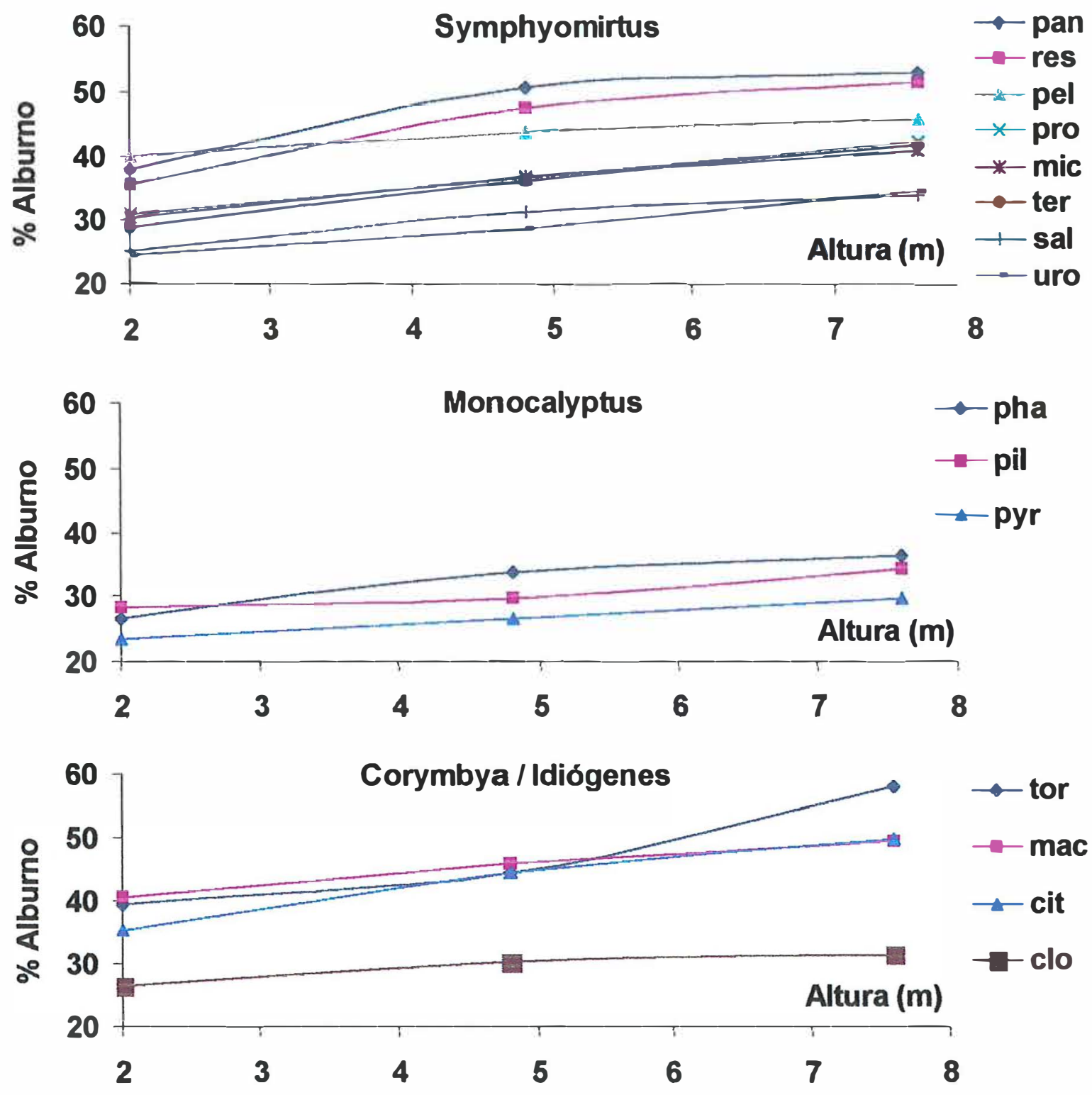

Figura 12 - Variação da percentagem de alburno no fuste, de Eucalyptus. 
A percentagem de alburno tem grande importância porque fornece madeira serrada de cor, quase sempre, diferente daquela produzida pelo cerne. A mistura de cerne e alburno numa mesma peça pode até desclassificala, visualmente, para certos usos.

Em alguns paises Europeus, mais tradicionais na utilização da madeira, em certas aplicações a mistura de cerne e alburno, de cores diferentes numa mesma peça de madeira em uso, é considerada como um defeito, podendo rebaixá-la da primeira para terceira classe.

Na proposta da comissão de estudos para elaboração de normas para classificação de madeira serrada de eucalipto da ABPM/IPT, o alburno não é considerado como quesito e, portanto, deixa a falsa impressão de que ele, não interfere na qualidade e na classificação da madeira.

\subsection{Percentagem de casca}

$\mathrm{Na}$ produção de madeira serrada em escala industrial, a percentagem de casca passa a constituir-se num fator importante, porque segundo Oliveira (1997), dependendo da grandeza deste valor, pode-se incorrer no erro de superestimar a produtividade ou o rendimentos, quando são feitas apenas análises mais superficiais dos fustes produzidos por diversas espécies de eucaliptos.

Os valores encontrados para as percentagens de casca das toras, no presente estudo, são encontrados na Tabela 12. Verifica-se que a maior percentagem de casca média da tora, foi encontrada no $E$. paniculata com $18,03 \%$, seguido do $E$. pellita com $17,80 \%$. A média mínima de casca foi a do $E$. torelliana com $9,34 \%$, seguida do $E$. tereticornis com $9,88 \%$. 
Tabela 12. Estatísticas descritivas das percentagens de casca.

\begin{tabular}{lccccccc}
\hline Espécies & $\begin{array}{c}\text { Média } \\
(\%)\end{array}$ & $\begin{array}{c}\text { Máxima } \\
(\%)\end{array}$ & $\begin{array}{c}\text { Mínimo } \\
(\%)\end{array}$ & s & CV (\%) & $S_{\text {x }}^{-}$ & $\begin{array}{c}\text { Variação da } \\
\text { espessura }(c m)\end{array}$ \\
\hline E. paniculata & 18,03 & 19,48 & 16,73 & 1,27 & 27,56 & 1,54 & $1,3-2,1$ \\
E. pellita & 17,80 & 21,74 & 15,49 & 2,59 & 14,55 & 1,06 & $1,5-2,6$ \\
E. phaeotricha & 15,95 & 21,12 & 12,01 & 3,86 & 24,20 & 1,58 & $0,6-1,8$ \\
E. resinifera & 15,89 & 19,56 & 10,20 & 3,80 & 23,93 & 1,55 & $1,1-3,5$ \\
E. cloeziana & 15,58 & 19,00 & 13,18 & 2,43 & 15,60 & 0,99 & $1,2-2,0$ \\
E. microcorys & 15,14 & 17,60 & 11,33 & 2,36 & 15,59 & 0,97 & $1,1-1,8$ \\
E. citriodora & 13,64 & 18,95 & 9,23 & 3,76 & 27,56 & 1,54 & $1,0-1,9$ \\
E. propinqua & 13,47 & 17,83 & 9,99 & 3,33 & 24,72 & 1,36 & $0,7-1,3$ \\
E. maculata & 13,37 & 17,36 & 10,26 & 2,82 & 21,09 & 1,15 & $1,1-2,1$ \\
E. pyrocarpa & 12,54 & 16,07 & 9,12 & 2,61 & 20,81 & 1,06 & $0,8-2,2$ \\
E. urophylla & 12,09 & 20,27 & 5,30 & 5,51 & 45,67 & 2,16 & $0,9-2,2$ \\
E. pilularis & 11,83 & 18,87 & 6,98 & 4,77 & 40,32 & 2,24 & $1,0-2,1$ \\
E. saligna & 10,02 & 15,47 & 5,97 & 3,71 & 37,05 & 1,52 & $0,8-1,1$ \\
E. tereticomis & 9,88 & 12,68 & 7,54 & 1,73 & 17,51 & 0,71 & $0,6-1,3$ \\
E. toreliana & 9,34 & 16,36 & 5,41 & 4,40 & 45,67 & 2,25 & $0,5-1,4$ \\
\hline
\end{tabular}

S - Desvio padräo

$\mathbf{S}_{\mathbf{x}}^{-}$- Erro padrão da média

Entre as médias máximas de casca, a maior percentagem foi verificada no $E$. pellita e no $E$. phaeotricha com $21,74 \%$ e $21,12 \%$, respectivamente, ambas na tora da base. Entre as médias mínimas a menor percentagem foi apresentada pelo $E$. urophylla com $5,30 \%$ e pelo $E$. torelliana com $5,41 \%$ de casca.

O E. paniculata foi o que teve o menor coeficiente de variação 7,81 $\%$, mostrando que esta característica varia menos do que para as demais espécies. Este valor está próximo daquele obtido por Oliveira (1997), que obteve um CV de 10,1\%, para a mesma espécie. No outro extremo está o E. toreliana que apresentou o maior coeficiente de variação, $47,10 \%$.

$O$ alto coeficiente de variação encontrado para no $E$. toreliana foi conseqüência da grande quantidade de casca apresentada por uma de suas árvores, com quase o dobro de casca das outras duas árvores.

As espessuras das cascas variaram de $0,5 \mathrm{~cm}$ no $E$. toreliana até $3,5 \mathrm{~cm}$ no $E$. resinifera. O E. paniculata apresentou a maior percentagem, ao passo que o $E$. resinifera apresentou a maior espessura de casca. 
Tabela 13. Análise da variância da percentagem de casca das quinze espécies de Eucalyptus.

\begin{tabular}{lcl}
\hline Causas de variação & GL & Pr $>F$ \\
\hline Espécie (E) & 14 & 0,0003 \\
Toras (T) & 1 & 0,0412 \\
E XT & 14 & 0,9902 \\
Resíduo & 29 & \\
\hline
\end{tabular}

$$
\mathrm{CV}=27,33 \%
$$

Verifica-se na Tabela 13 mostra que existem diferenças significativas entre as espécies e também entre as toras. Entretanto, não houve interação da espécie com a tora, significando que a variação da percentagem de casca da tora da base para a subsequente, segue 0 mesmo padrão em todas as espécies.

Tabela 14. Percentagem de casca dos subgêneros de Eucalyptus, comparados pelo teste de Bonferroni.

\begin{tabular}{lcc}
\hline Causa de variação & $(\%)$ de casca & Grupo (1) \\
\hline Idiogenes & 15,58 & $\mathrm{a}$ \\
Symphyomyrtus & 14,04 & $\mathrm{a}$ \\
Monocalyptus & 13,32 & $\mathrm{a}$ \\
Corymbia & 12,12 & $\mathrm{a}$
\end{tabular}

(1) Médias com a mesma letra não são significativamente diferentes entre si. CV $=31,34 \%$.

A comparação entre as médias, pelo teste de Bonferroni ao nível de $5 \%$ de probabilidade, para a percentagem de casca, revelou que não existem diferenças significativas entre os subgêneros.

A Tabela 15 mostra que dentro do subgênero Symphyomyrtus, o $E$. paniculata e $\circ E$. pellita diferem significativamente do $E$. tereticornis e $E$. saligna. Nos subgêneros Monocalyptus e Corymbia as espécies não diferem significativamente entre si, quanto à percentagem de casca. 
Tabela 15. Comparação das médias de casca pelo teste de Bonferroni.

\begin{tabular}{|c|c|c|c|c|}
\hline Subgênero & Espécies & $\begin{array}{c}\text { Casca } \\
(\%)\end{array}$ & $\begin{array}{l}\text { Espécies dentro } \\
\text { de subgênero (1) }\end{array}$ & $\begin{array}{c}\text { Espécies dentro do } \\
\text { gênero (1) }\end{array}$ \\
\hline \multirow{8}{*}{ Symphyomyrtus } & E. paniculata & 18,03 & a & a \\
\hline & E. pellita & 17,80 & $a$ & a \\
\hline & E. resinifera & 15,89 & $a b$ & $a b$ \\
\hline & E. microcorys & 15,14 & $a b$ & $a b$ \\
\hline & E. propinqua & 13,47 & $a b$ & $a b$ \\
\hline & E. urophylla & 12,09 & $a b$ & $a b$ \\
\hline & E. saligna & 10,02 & b & b \\
\hline & E. tereticornis & 9,88 & b & b \\
\hline \multirow{3}{*}{ Monocalyptus } & E. phaeotricha & 15,95 & a & $a b$ \\
\hline & E. pyrocarpa & 12,54 & a & $a b$ \\
\hline & E. pilularis & 11,48 & a & $a b$ \\
\hline \multirow{3}{*}{ Corymbia } & E. citriodora & 13,64 & a & $a b$ \\
\hline & E. maculata & 13,37 & a & $a b$ \\
\hline & E. torelliana & 9,34 & a & b \\
\hline Idiogenes & E. cloeziana & 15,58 & & $a b$ \\
\hline
\end{tabular}

(1) Médias com a mesma letra não são significativamente diferentes entre si. $C V=27,33 \%$.

A comparação entre médias, através do teste de Bonferroni, ao nível de 5 $\%$ de significáncia, para a percentagem média de casca, revelou que, dentro do gênero Eucalyptus, as espécies $E$. paniculata e E. pellita diferem significativamente do E. toreliana, E. tereticornis e E. saligna. Todas as demais espécies formam um grupo intermediário, que ora se assemelham ao grupo do $E$. paniculata e ora se assemelham ao grupo do E. torelliana. A Figura 13 possibilita uma comparação relativa das espécies.

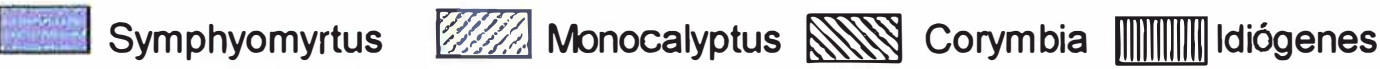

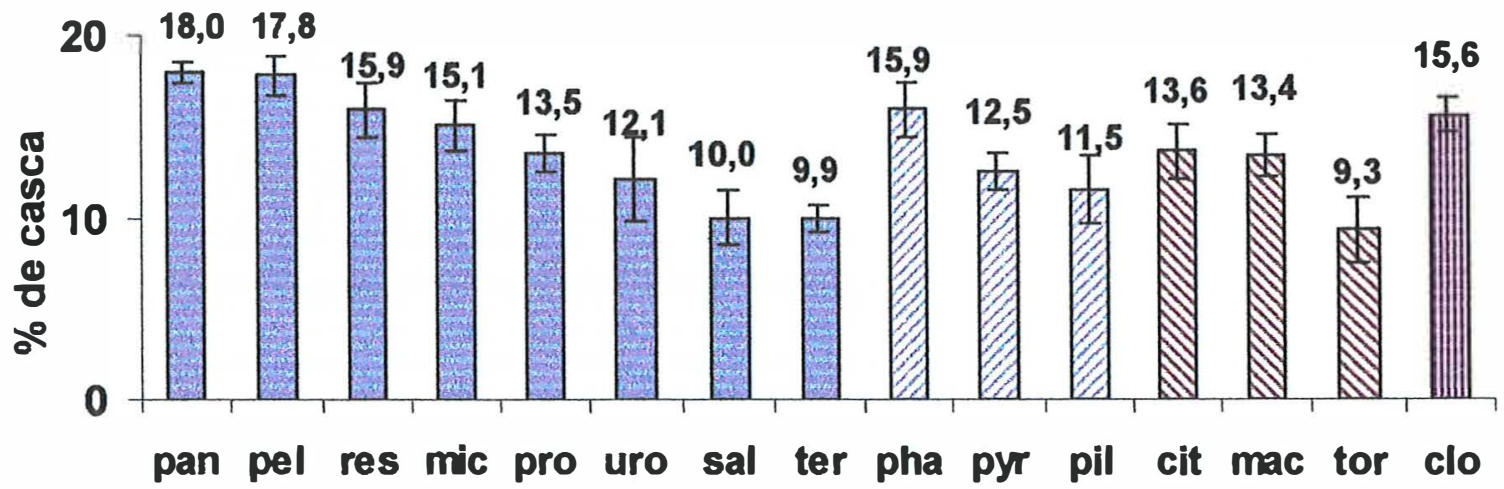

Figura 13 - Percentagem média de casca das 15 espécies de Eucalyptus. 
A percentagem de casca varia com a espécie, entre árvores de uma mesma espécie e ao longo do tronco da árvore. Podem também variar de acordo com as condições ambientais e do sítio. Segundo Loetsch et al. (1973), algumas espécies possuem uma percentagem de casca constante da base até o topo da árvore, enquanto que outras apresentam grandes variações da percentagem de casca ao longo do fuste. Assman (1970) encontrou em árvores de Pseudotsuga manziesii, na altura de $10 \mathrm{~m}$, uma percentagem de $9 \%$ de casca e para uma altura de $34 \mathrm{~m}, 16 \%$ de casca. Lopes (2000), concluiu que no E. saligna a casca rugosa é mais espessa que a casca lisa e que a percentagem de casca diminui com o aumento da altura na árvore.

A Figura 14 mostra que a espessura da casca diminui da tora A para a tora B. Este decréscimo ocorre, em média para as espécies, numa taxa de $1,05 \mathrm{~cm}$ por $5,6 \mathrm{~m}$ de comprimento, ou seja, $0,189 \mathrm{~cm} / \mathrm{metro}$ de fuste.

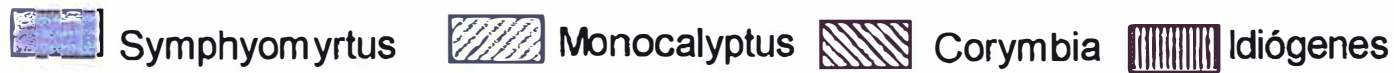

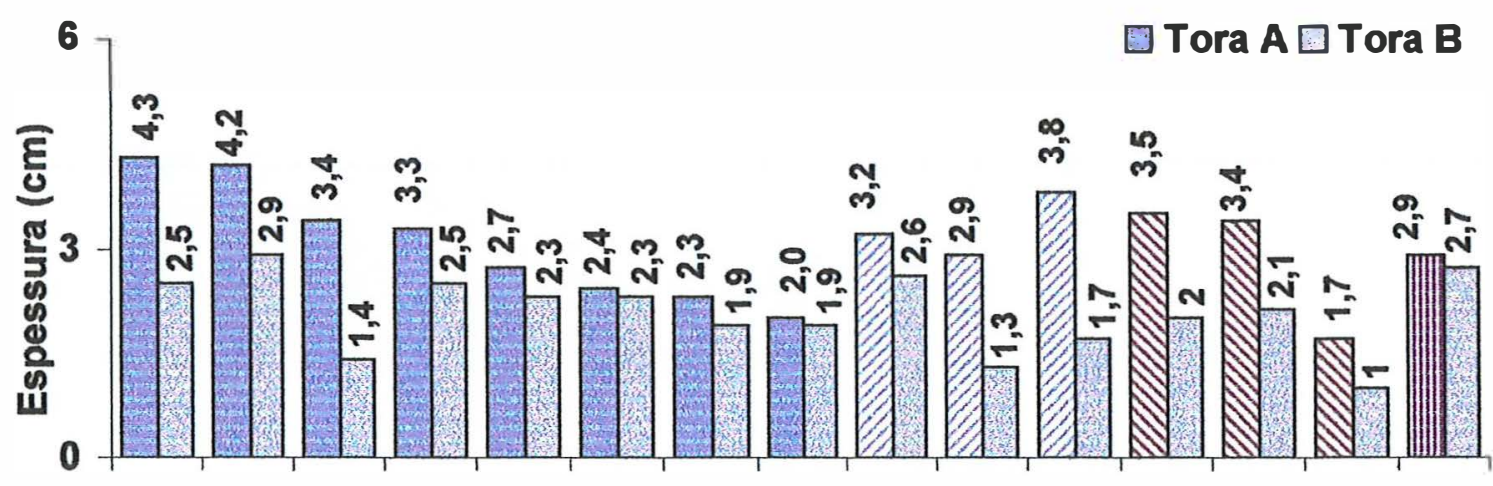

res pan pro pel mic ter uro sal pha pill pyr mac cit tor clo

Figura 14 - Espessura média da casca na tora da base (tora A) e de topo (tora B)

A figura 15 apresenta as percentagens médias de casca nas toras de base e nas subsequentes das quinze espécies de Eucalyptus. 
$\square$ Symphyomyrtus $\quad$ Monocalyptus $\quad$ Corymbia

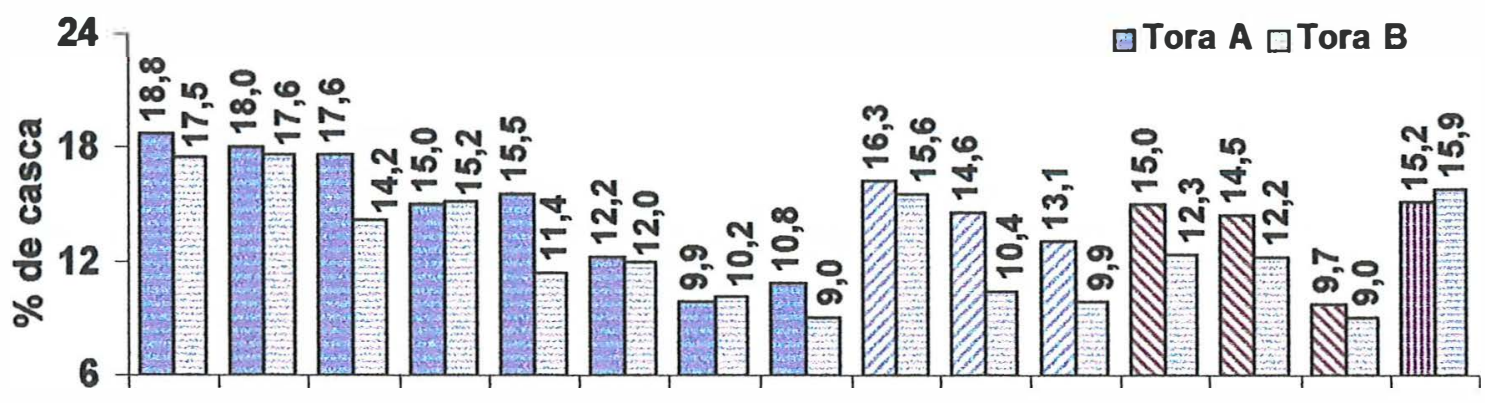

pan pel res mic pro uro sal ter pha pyr pil cit mac tor clo

Figura 15 - Percentagem de casca na tora de base (tora A) e na subsequente (tora B).

Nunes (1981), estudando o volume e a percentagem de casca ao longo do tronco de E. grandis, E. alba e E. saligna, concluiu que, para as três espécies de Eucalyptus estudadas, o volume de casca aumentou com a idade, enquanto que a percentagem de casca diminuiu. $O$ decréscimo na percentagem de casca com a altura na árvore foi mais pronunciado nas menores classes de DAP, sendo insignificante para as maiores classes de diâmetro. Obteve para o E. grandis com idade variando de 3 a 7 anos uma percentagem média de casca de $14,7 \%$. No $E$. alba 5,6 a 8 anos de idade, obteve uma média de 14,8\%.

As Figuras 16 e 17 mostram os tipos de casca existentes entre as espécies de eucaliptos envolvidas no presente estudo. Dentro do subgênero Symphyomyrtus, as espécies apresentaram diversos tipos de casca, como a lisa, fibrosa, rugosa e suberosa. Já no Monocalyptus, as espécies apresentaram apenas casca fibrosa e no Corymbia predominou a casca lisa. A única espécie do subgênero Idiogenes, o E. cloeziana apresenta casca rugosa. 


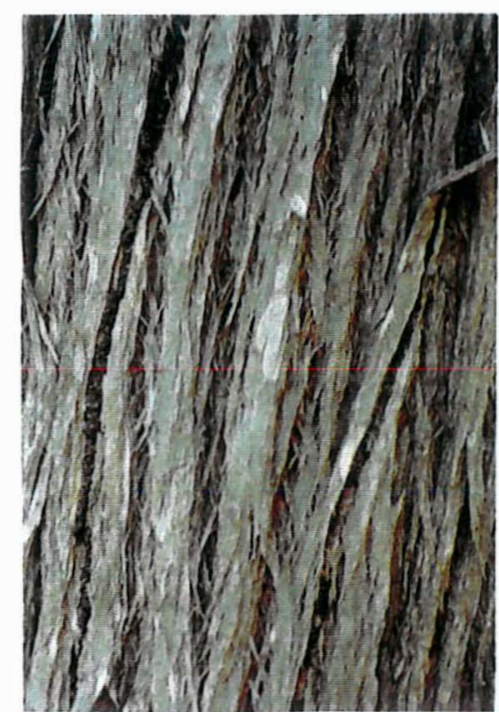

E. pellita (fibrosa)(s)

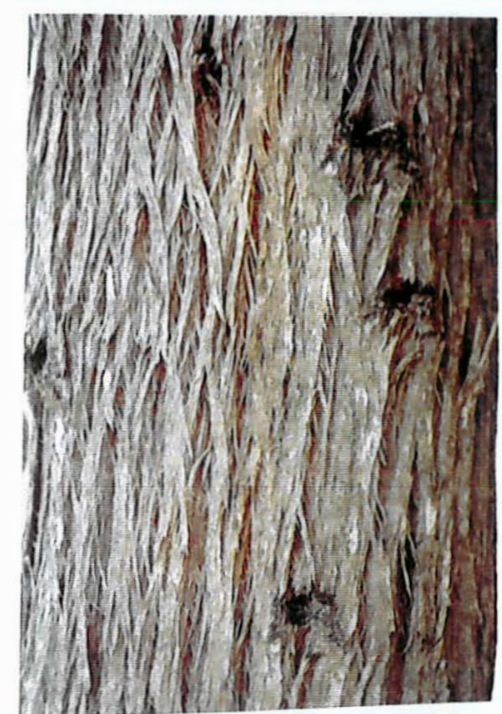

E. resinifera (fibrosa)(s)

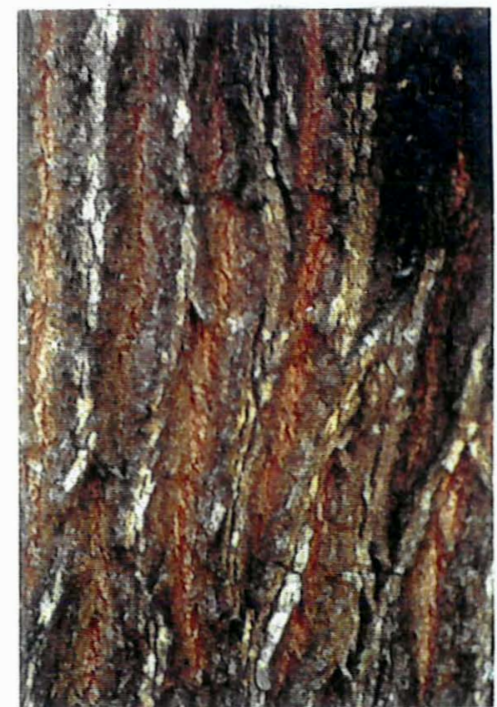

E. paniculata (suberosa)(s)

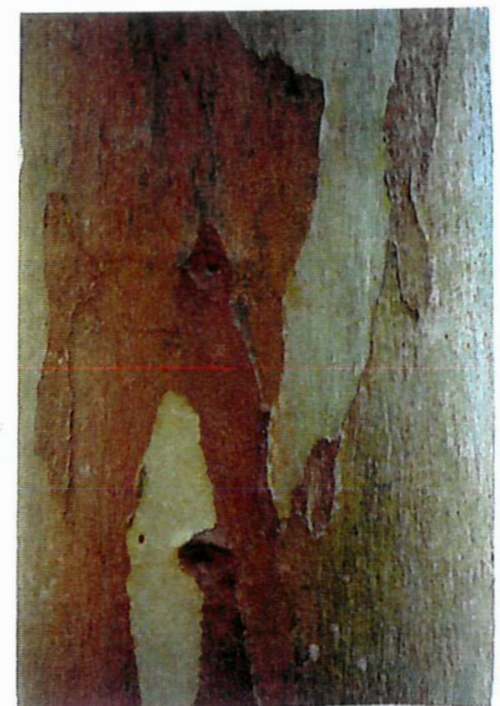

E. tereticornis (lisa)(s)

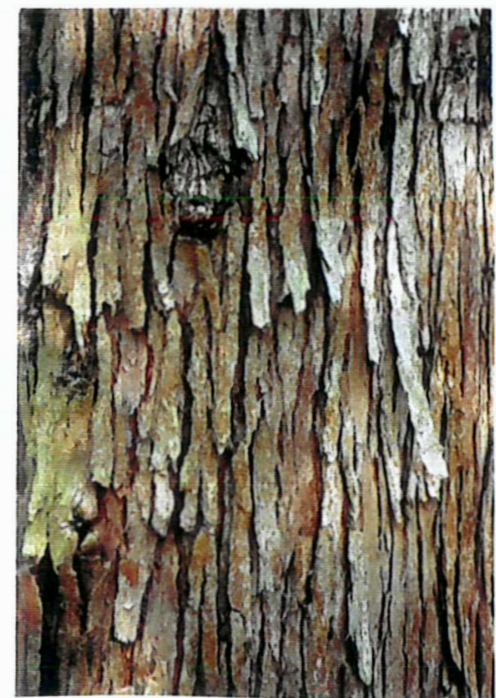

E. urophylla (fibrosa)(s)

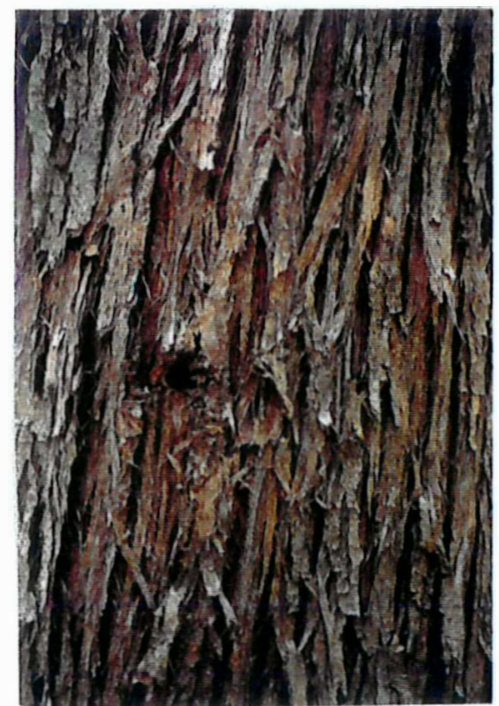

E. microcorys (fibrosa)(s)

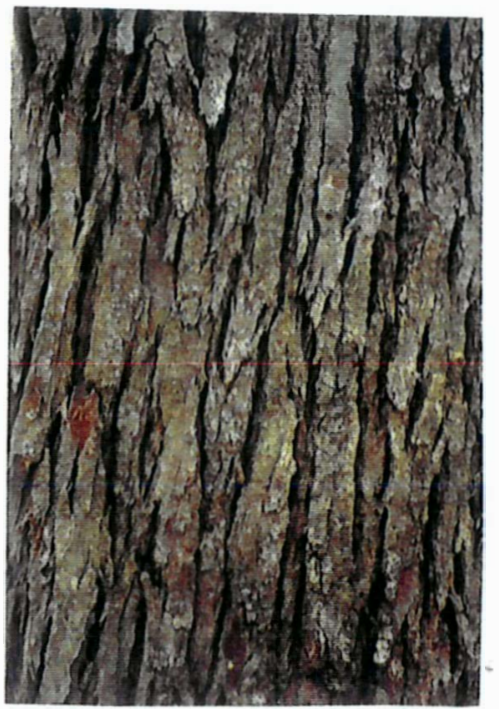

E. saligna (fibrosa)(s)

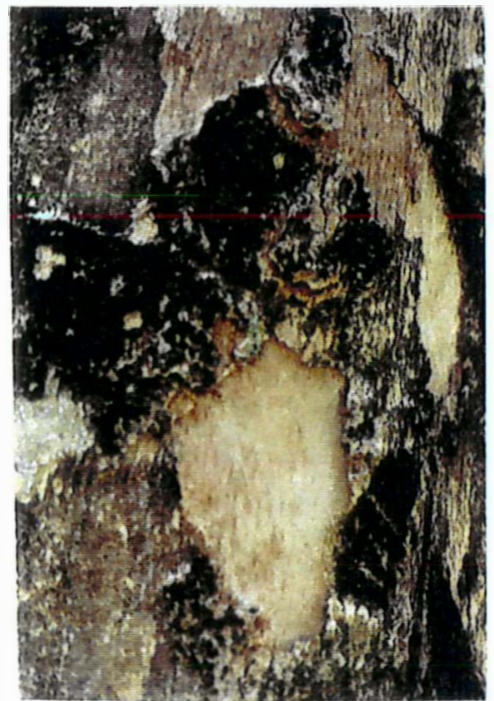

E. propinqua (rugosa)(s)

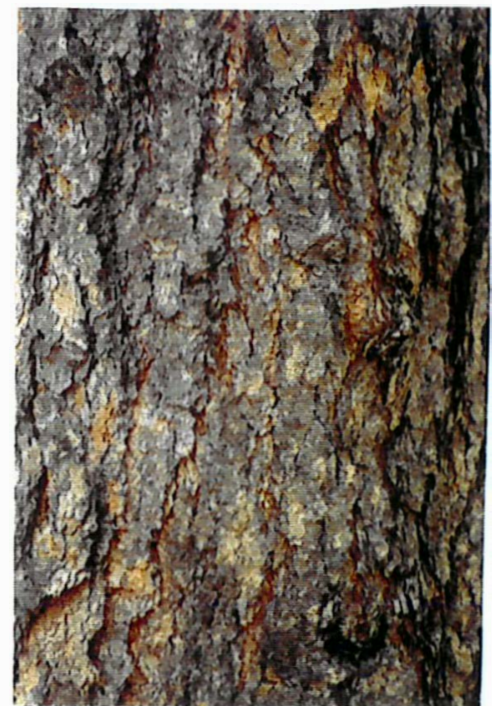

E. cloeziana (rugosa)(i)

Figura 16 - Tipos de casca das espécies dos Subgêneros Symphyomyrtus (s) e Idiogenes (i). 

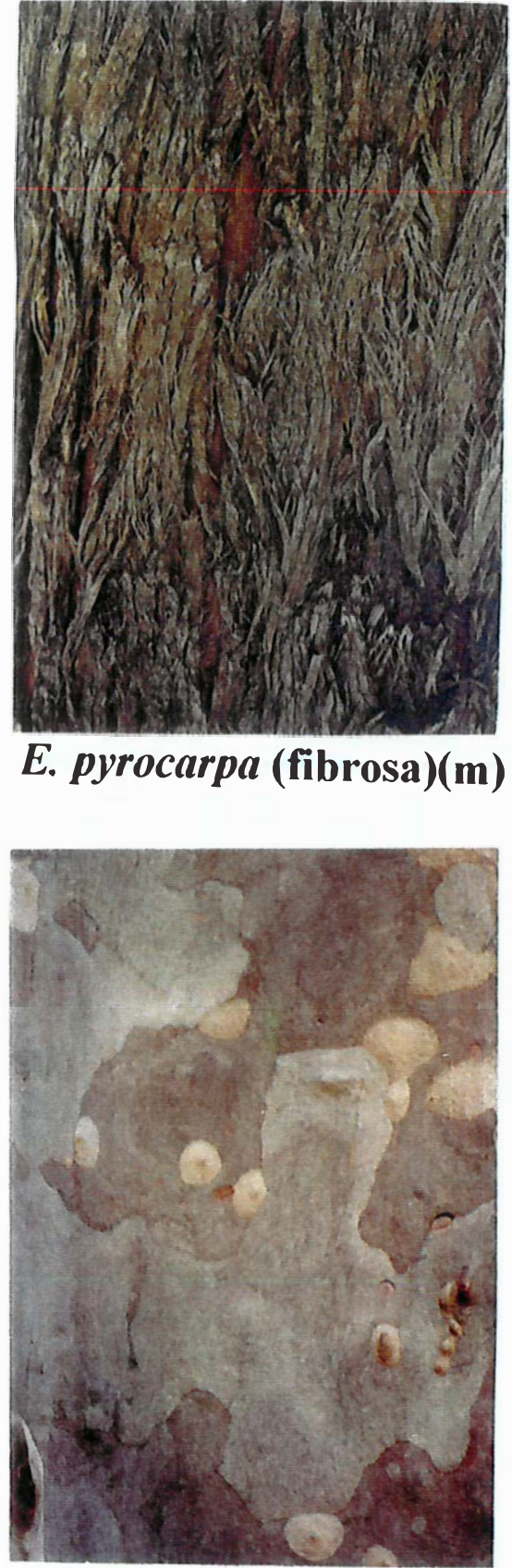

E. citriodora (lisa)(c)

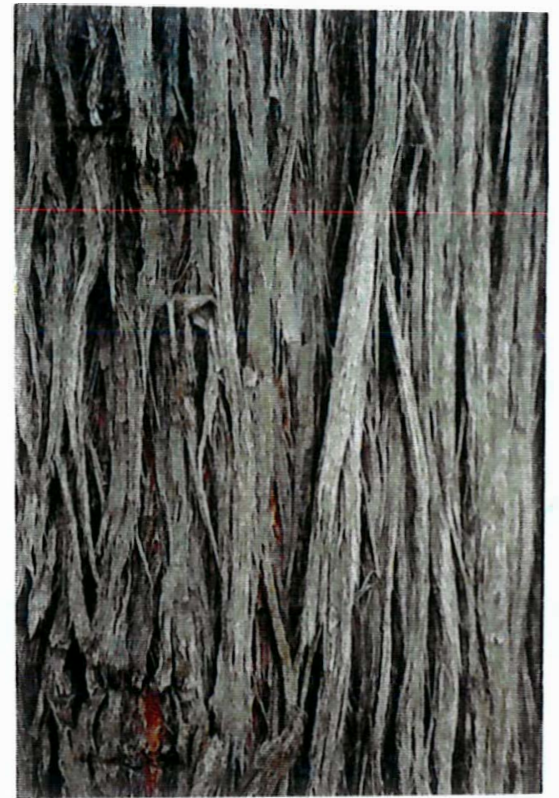

E. phaeotricha (fibrosa)(m)

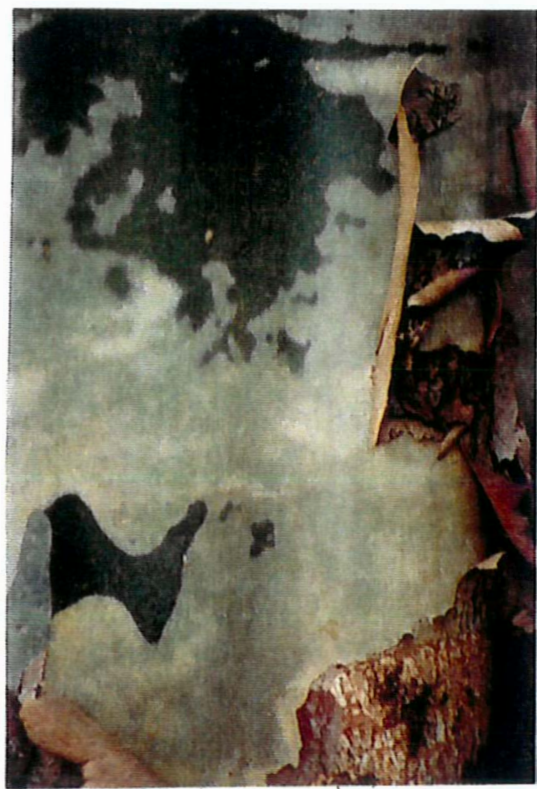

E. torelliana (lisa)(c)

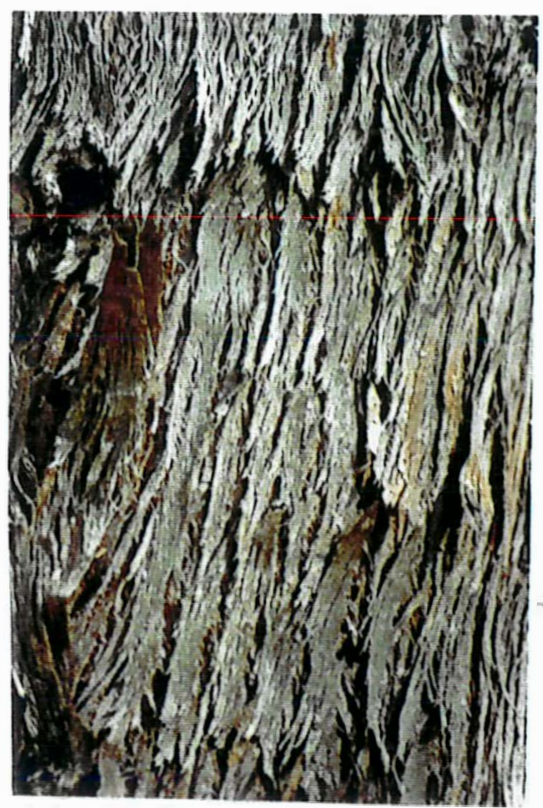

E. pilularis (fibrosa)(m)

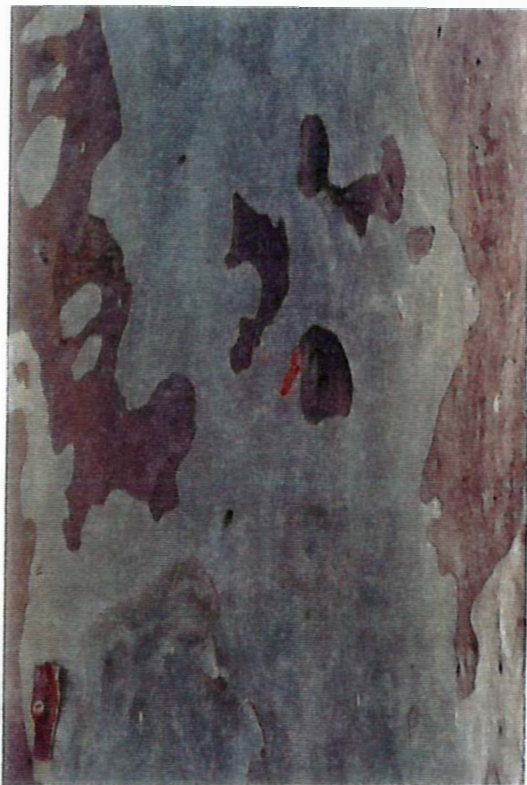

E. maculata (lisa)(c)

Figura 17 - Tipos de casca das espécies dos Subgêneros Monocalyptus (m) e Corymbia (c). 
Em algumas espécies, estes tipos de casca apresentados, sofrem variações ao longo do fuste, como por exemplo o E. urophylla e o E. saligna, que apresentam casca lisa na parte superior do tronco.

Oliveira (1997) estudando a percentagem de casca em sete espécies de Eucalyptus, verificou uma alta percentagem de casca na base da árvore, uma queda nas posições intermediárias, e um novo aumento no topo das árvores. Entretanto, Nunes (1981), estudando E. alba e E. grandis de origem hibrida, concluiu que as percentagens de casca observadas nas várias alturas do tronco das árvores diferiram estatisticamente entre si. As percentagens menores foram encontradas nas menores alturas, tendendo a se estabilizar a partir de aproximadamente 4 metros.

Segundo Oliveira (1997), além dos diferentes tipos de casca das diferentes espécies de eucaliptos (lisa, fibrosa, feltrosa, suberosa, rugosa, laminar), caducas ou não, existe grande variabilidade quanto à sua proporção em relação ao material lenhoso útil. A percentagem de casca presente no gênero Eucalyptus, varia de 10 a $40 \%$ da produção lenhosa. Nas espécies de casca lisa e caduca, como no caso do E. maculata e E. tereticornis a percentagem de casca é menor, da ordem de 10 a $25 \%$. Esses dados corroboram aos valores obtidos no presente estudo, onde para - E. tereticornis, o E. maculata, o E. toreliana e o E. citriodora, que são espécies de casca lisa, apresentaram percentagem de casca de $9,88 \%$, $13,37 \%$ e $9,31 \%$, e $13,64 \%$ respectivamente.

Estudos conduzidos pela FAO (1981) demonstram que a maior parte dos resultados publicados, concordam que a percentagem de casca diminui com o aumento da altura na árvore. 


\subsection{Conicidade das toras}

A conicidade é uma característica pouco acentuada no gênero Eucalyptus, ocorrendo apenas pequenas variações entre espécies. Os maiores gradientes de conicidade ocorrem nas alturas inferiores das árvores. A forma mais cônica na base serve para reforçar a sua estabilidade, por ser esta a região de maiores esforços de equilíbrio da árvore. As duas toras consideradas no presente estudo, estão compreendidas entre $2,0 \mathrm{~m}$ à 7,6 m, retiradas de posições de diferentes conicidades, fator este que aumentou a variabilidade dentro da árvore.

A Tabela 16 mostra os aitos coeficientes de variação encontrados dentro das espécies de Eucalyptus, que superam, na maioria dos casos, o CV experimental.

Tabela 16. Conicidades médias de toras, sem casca.

\begin{tabular}{lcccccc}
\hline Espécie & Média & Máxima & Mínima & s & CV \% & $S_{\bar{x}}^{-}$ \\
\hline E. torelliana & 1,36 & 2,5 & 0,86 & 0,643 & 47,28 & 0,263 \\
E. pyrocarpa & 1,17 & 1,61 & 0,71 & 0,319 & 27,26 & 0,13 \\
E. pellita & 1,12 & 1,68 & 0,57 & 0,407 & 36,34 & 0,166 \\
E. resinifera & 1,08 & 1,61 & 0,68 & 0,373 & 34,53 & 0,152 \\
E. tereticomis & 1,05 & 1,89 & 0,43 & 0,554 & 52,51 & 0,226 \\
E. cloeziana & 1,03 & 1,57 & 0,64 & 0,395 & 38,35 & 0,161 \\
E. propinqua & 1,01 & 1,71 & 0,57 & 0,436 & 43,6 & 0,178 \\
E. maculata & 0,96 & 1,43 & 0,75 & 0,255 & 26,56 & 0,104 \\
E. microcorys & 0,96 & 1,86 & 0,43 & 0,512 & 53,3 & 0,209 \\
E. phaeotricha & 0,93 & 1,32 & 0,67 & 0,259 & 27,85 & 0,106 \\
E. urophylla & 0,86 & 2,32 & 0,07 & 0,887 & 102,8 & 0,362 \\
E. saligna & 0,77 & 1,5 & 0,36 & 0,443 & 55,38 & 0,181 \\
E. citrodora & 0,67 & 1,32 & 0,11 & 0,422 & 62,98 & 0,172 \\
E. paniculata & 0,67 & 0,78 & 0,32 & 0,18 & 26,87 & 0,074 \\
E. pilularis & 0,55 & 1,00 & 0,04 & 0,406 & 73,82 & 0,166 \\
\hline \multicolumn{1}{c}{ s= Desvio padrão } & \multicolumn{7}{c}{$\mathrm{CV}=$ Coeficiente de variação } & \multicolumn{2}{c}{$\mathrm{S}_{\mathbf{x}}^{-}=$Erro Padrão da Média }
\end{tabular}

A conicidade média de todas as espécies foi de $0,95 \mathrm{~cm}$ por metro. A espécie que apresentou a maior conicidade média foi o $E$. toreliana com 1,36 $\mathrm{cm} / \mathrm{m}$. A menor conicidade média foi a do $E$. pilularis com $0,55 \mathrm{~cm} / \mathrm{m}$. 
Com exceção do $E$. pilularis, as toras da base podem ser classificadas como sendo mais cônicas, ocorrendo uma diminuição significativa na conicidade das toras na altura intermediária da árvore.

O elevado coeficiente de variação de $37,85 \%$ verificado para esta característica, reflete a variabilidade existente dentro do gênero num intervalo compreendido entre um máximo de $2,50 \mathrm{~cm} / \mathrm{m}$ para o $E$. torelliana e um mínimo de $0,04 \mathrm{~cm} / \mathrm{m}$, para $\circ$ E. pilularis. As toras da base apresentam em média, aproximadamente, o dobro da conicidade da tora subsequente.

Os resultados da análise de variância aplicada aos valores de conicidade das espécies em estudo encontram-se na Tabela 17.

Tabela 17. Análise da variância aplicada à conicidade de toras sem casca.

\begin{tabular}{lcl}
\hline Causa de variação & GL & $\operatorname{Pr}>F$ \\
\hline Espécie & 14 & 0,0221 \\
Toras & 1 & 0,0001 \\
Espécie X Tora & 14 & 0,9050 \\
Resíduo & 29 &
\end{tabular}

$\mathrm{CV}=37,85 \%$

Observa-se na Tabela 17, que existem diferenças altamente significativas de conicidade entre espécies e entre toras. Entretanto as diferenças são mais acentuadas entre toras do que entre espécies. Não houve interação da espécie com a posição na árvore, significando que a tendência de decréscimo da conicidade da base para o topo é a mesma para todas as 15 espécies.

Tabela 18. Conicidade média de toras sem casca dos 4 subgêneros.

\begin{tabular}{lcc}
\hline Subgêneros & Conicidade média & Grupo (1) \\
\hline Idiogenes & 1,03 & $\mathrm{a}$ \\
Corymbia & 0,99 & $\mathrm{a}$ \\
Symphyomyrtus & 0,94 & $\mathrm{a}$ \\
Monocalyptus & 0,88 & $\mathrm{a}$ \\
\hline
\end{tabular}

(1) Médias com a mesma letra não são significativamente diferentes entre si.

(2) $\mathrm{CV}=40,48 \%$ 
A comparação entre as médias da conicidade dos subgêneros, pelo teste de Bonferroni ao nível de $5 \%$ de probabilidade, revelou que não existem diferenças significativas de conicidades entre eles, (Tabela 18).

Tabela 19. Teste de comparação múltipla de Bonferroni para conicidade.

\begin{tabular}{llccc}
\hline Subgênero & $\begin{array}{c}\text { Causas de } \\
\text { variação }\end{array}$ & $\begin{array}{c}\text { Conicidade } \\
\text { Média }(\mathrm{cm} / \mathrm{m})\end{array}$ & $\begin{array}{c}\text { Espécies dentro } \\
\text { de subgênero (1) }\end{array}$ & $\begin{array}{c}\text { Espécies dentro } \\
\text { do gênero (1) }\end{array}$ \\
\hline \multirow{5}{*}{ Symphyomyrtus } & E. pellita & 1,12 & $\mathrm{a}$ & $\mathrm{ab}$ \\
& E. resinifera & 1,08 & $\mathrm{a}$ & $\mathrm{ab}$ \\
& E. tereticomis & 1,04 & $\mathrm{a}$ & $\mathrm{ab}$ \\
& E. propinqua & 1,01 & $\mathrm{a}$ & $\mathrm{ab}$ \\
& E. microcorys & 0,96 & $\mathrm{a}$ & $\mathrm{ab}$ \\
& E. urophylla & 0,86 & $\mathrm{a}$ & $\mathrm{ab}$ \\
Monocalyptus & E. saligna & 0,77 & $\mathrm{a}$ & $\mathrm{ab}$ \\
& E. paniculata & 0,67 & $\mathrm{a}$ & $\mathrm{ab}$ \\
& E. pyrocarpa & 1,17 & $\mathrm{a}$ & $\mathrm{ab}$ \\
& E. phaeotricha & 0,93 & $\mathrm{a}$ & $\mathrm{ab}$ \\
Corymbia & E. pilularis & 0,55 & $\mathrm{~b}$ & $\mathrm{~b}$ \\
& E. torelliana & 1,36 & $\mathrm{a}$ & $\mathrm{a}$ \\
Idiogenes & E. maculata & 0,96 & $\mathrm{a}$ & $\mathrm{ab}$ \\
& E. citriodora & 0,67 & $\mathrm{a}$ & $\mathrm{ab}$ \\
\hline
\end{tabular}

(3) Médias com a mesma letra não são significativamente diferentes entre si.

(4) $C V=37,85 \%$

Aplicando-se o teste de Bonferroni ao nível de $5 \%$ de probabilidade aos valores de conicidade das quinze espécies dentro do gênero, foi possível hierarquizar as espécies, como mostra a Tabela 19. Apenas o E. pilularis diferiu significativamente do $E$. torelliana. As demais espécies formam um grupo intermediário e não diferem significativamente entre si.

Nas espécies que compreendem o subgênero Symphyomyrtus, não foram encontradas diferenças significativas. No subgênero Monocalyptus o $E$. pilularis diferiu significativamente do grupo composto pelo $E$. pyrocarpa e $E$. phaeotricha. No subgênero Corymbia as espécies não diferiram estatisticamente entre si.

Miranda (1997) encontrou para o E. saligna, de 9 anos de idade, uma conicidade média das toras de $0,76 \mathrm{~cm} / \mathrm{m}$, valor idêntico à conicidade obtida nesse estudo $(0,77 \mathrm{~cm} / \mathrm{m})$, com árvores de 23 anos. Isso pode demonstrar que a 
conicidade é uma característica muito pouco variável entre indivíduos e praticamente permanece estável com $\circ$ avanço da idade, mesmo em povoamentos e manejos distintos.

A figura 18 mostra, de uma forma mais clara, as diferenças observadas entre espécies.

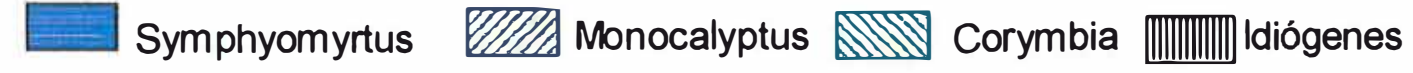

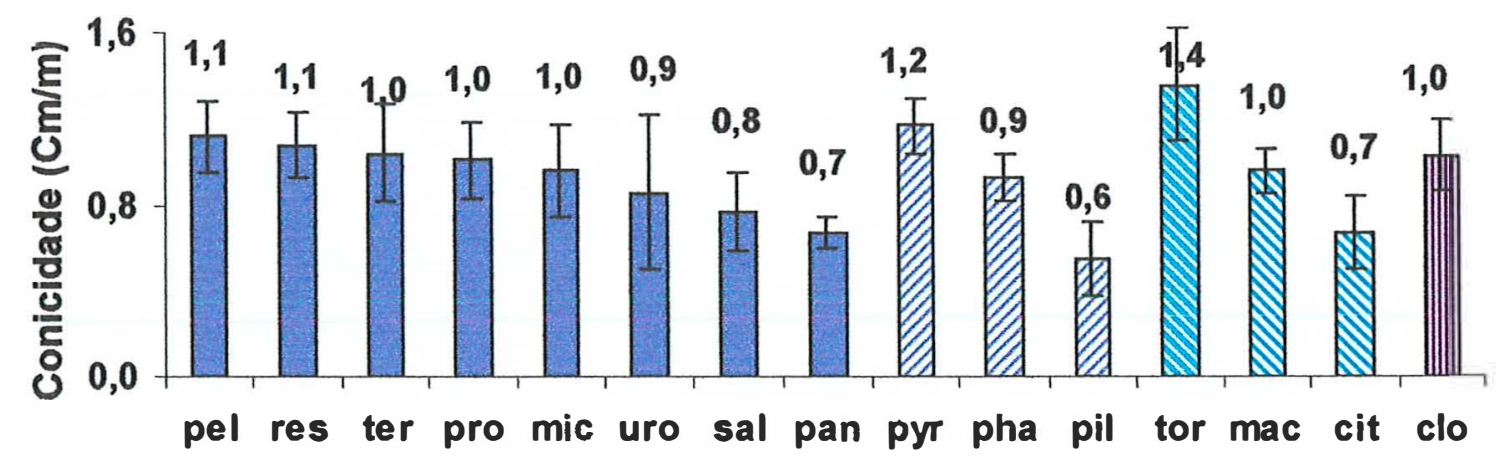

Figura 18 - Distribuição da conicidade média nas quinze espécies de Eucalyptus.

Na Figura 19, pode-se observar que a conicidade da segunda tora da árvore é cerca da metade daquela da tora basal. A média de conicidade da tora " $A$ ", compreendida entre 2,00 a 4,80 m, foi de $1,24 \mathrm{~cm} / \mathrm{m}$ com um CV de 25,12 $\%$ e na tora "B", entre 4,80 a $7,50 \mathrm{~m}$, a conicidade foi de $0,66 \mathrm{~cm} / \mathrm{m}$ e maior variação nos resultados com um CV de 46,70 \%.

- Symphyomyrtus VIItA Monocalyptus $M$ Corymbia

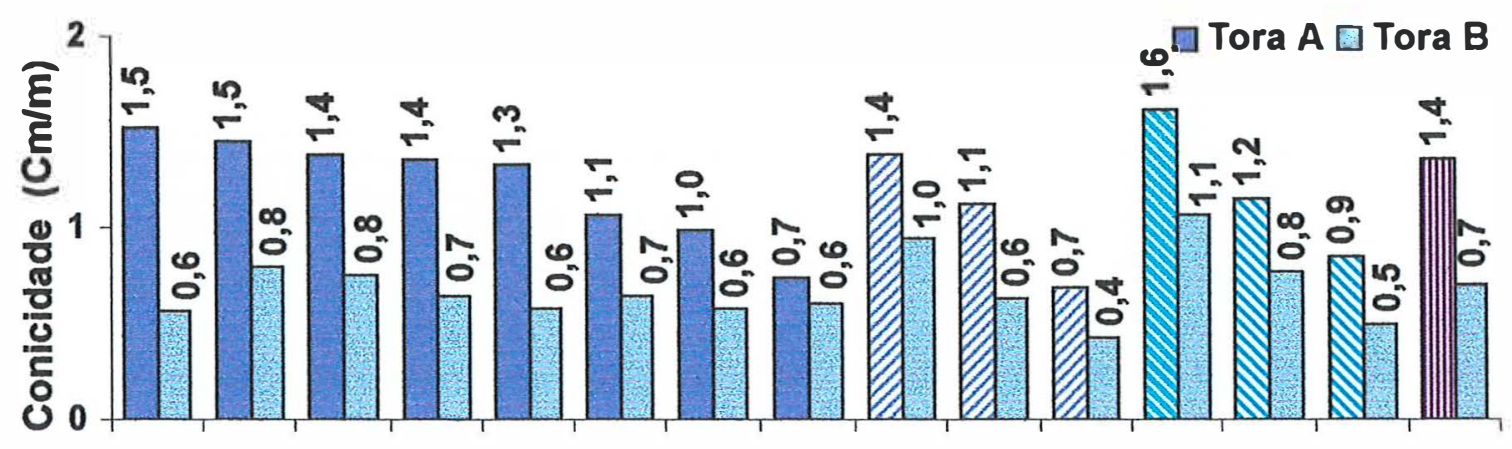

ter pel res pro mic uro sal pan pyr pil pha tor mac cit clo

Figura 19 - Conicidade média de toras sem casca, das quinze espécies de Eucalyptus. 
Estes resultados são corroborados por Oliveira (1997), que estudando sete espécies de Eucalyptus, encontrou para a primeira tora, de 0 a 4 metros, uma conicidade de $2,02 \mathrm{~cm} / \mathrm{m}$, e para a segunda tora, de 4 a 8 metros, uma conicidade de $0,67 \mathrm{~cm} / \mathrm{m}$.

\subsection{Incidência de nós}

A operação de desrama é fundamental para obtenção de madeira "clear". Vários madeireiros e pesquisadores concordam, que a desrama em eucaliptos, deve ser iniciada o mais cedo possível. Os investimentos realizados nesta fase, são plenamente compensados pela produção de uma madeira de melhor qualidade e melhor preço no mercado.

Tabela 20. Incidência média de nós, obtido por face nas tábuas.

\begin{tabular}{lccccccc}
\hline Espécie & $\begin{array}{c}\text { Média } \\
(\mathrm{n})\end{array}$ & $\begin{array}{c}\text { Nó mortos } \\
(\%)\end{array}$ & $\begin{array}{c}\text { Mínimo } \\
(\mathrm{n})\end{array}$ & $\begin{array}{c}\text { Máximo } \\
(\mathrm{n})\end{array}$ & $\mathrm{s}$ & CV (\%) & $\mathrm{S}_{\overline{\mathrm{x}}}$ \\
\hline E. resinifera & 7,75 & 31,6 & 6,32 & 10,09 & 1,37 & 17,7 & 0,56 \\
E. torelliana & 6,97 & 18,5 & 4,64 & 9,16 & 1,84 & 26,4 & 0,75 \\
E. maculata & 5,20 & 41,3 & 3,32 & 6,75 & 1,30 & 25,0 & 0,53 \\
E. microcorys & 5,08 & 59,1 & 3,89 & 8,10 & 1,53 & 30,1 & 0,62 \\
E. paniculata & 4,96 & 48,1 & 3,50 & 5,95 & 0,35 & 7,0 & 0,35 \\
E. urophylla & 4,45 & 43,0 & 3,33 & 6,07 & 1,27 & 28,6 & 0,52 \\
E. saligna & 4,00 & 61,5 & 2,62 & 5,57 & 1,01 & 25,2 & 0,41 \\
E. pilularis & 3,92 & 65,7 & 2,71 & 5,65 & 1,08 & 27,5 & 0,44 \\
E. pellita & 3,47 & 76,5 & 2,61 & 4,61 & 0,73 & 21,0 & 0,30 \\
E. phaeotricha & 3,35 & 15,5 & 2,07 & 5,40 & 1,31 & 39,1 & 0,54 \\
E. propinqua & 3,24 & 17,8 & 1,59 & 5,95 & 1,57 & 48,5 & 0,64 \\
E. pyrocarpa & 3,17 & 77,3 & 1,04 & 4,58 & 1,27 & 40,0 & 0,52 \\
E. cloeziana & 2,98 & 20,8 & 2,03 & 3,66 & 0,71 & 23,7 & 0,29 \\
E. tereticomis & 2,41 & 38,1 & 1,43 & 3,15 & 0,65 & 26,9 & 0,265 \\
E. citriodora & 1,81 & 6,35 & 0,96 & 2,54 & 0,61 & 33,5 & 0,25 \\
\hline
\end{tabular}

$\mathrm{s}=$ Desvio Padrão $\quad \mathrm{CV}=$ Coeficiente de variação $\quad \mathrm{S}_{\mathrm{s}}^{-}=$Erro padrão da média $n=$ Número médio de nós por face de tábua.

Analisando-se a Tabela 20 verifica-se que a espécie com maior incidência de nós foi o $E$. resinifera com 7,75 nós por face, seguida do $E$. toreliana com 6,97, E. maculata com 5,20 e do E. microcorys com 5,08 nós, em cada lado da tábua. As espécies que apresentaram as menores freqüências foi 
o E.citriodora com 1,81, E. tereticornis com 2,41, e o E.cloeziana com 2,98 nós por face.

A maior percentagem de nós mortos, em relação ao número total de nós ocorreu no E. pyrocarpa $77,30 \%$, depois no $E$. pellita $76,50 \%$, e no E. pilularis $65,70 \%$. A menor percentagem de nós mortos por tábua foi apresentado pelo $E$. citriodora, com apenas $6,35 \%$. Logo a seguir vieram o E. phaeotricha, com $15,50 \%$ e o E. cloeziana com 20,80\%. Com estes dados pode-se inferir que o E. citriodora apresenta maior facilidade de auto-desrama do que o E. pyrocarpa que apresentou o maior índice de nós mortos. De qualquer maneira todas as espécies, merecem mais cuidados nos tratamentos silviculturais, caso a madeira se destine para serraria.

Estudando a influência do espaçamento de plantio, de Eucalyptus saligna de 9 anos de idade, no rendimento em madeira serrada, Miranda (1997) encontrou em média, 15 nós presentes na pior face de cada tábua. Esta média foi superior à obtido no presente trabalho, de 4 nós por face, em árvores de 23 anos de idade. Em árvores de maiores idades, existe a possibilidade de ter ocorrido um crescimento de lenho "clear", depois da ocorrência de uma desrama natural podendo-se produzir, consequentemente, uma maior quantidade de tábuas sem nós. Em idade mais jovens muitos galhos ainda estão inseridos no fuste para ajudar no desenvolvimento da árvore.

Nas 842 tábuas analisadas por Miranda (1997), foram observados, em média, 4 nós por metro linear de tábua, sendo que o valor máximo encontrado foi de 12 nós por metro. Apenas uma tábua não apresentou qualquer tipo de nó. $\mathrm{Na}$ avaliação dos nós soltos, observou-se que em torno de $50 \%$ deles apresentavam-se associados com resina.

O E. saligna apresentou nesse estudo, uma freqüência média de 1,43 nós por metro linear de tábua. $A$ tora com maior número médio de nós foi a do E. resinifera que apresentou 3,60 nós por/m. A freqüência mínima foi encontrada no E.citriodora, 0,34 nós por/m linear de tábua. 
Tabela 21. Análise da variância da Incidência média de nós, por face das tábuas.

\begin{tabular}{lcc}
\hline Causa de variação & GL & PrF \\
\hline Espécie & 14 & 0,0001 \\
Toras & 1 & 0,2467 \\
Esp X Tor & 14 & 0,7655 \\
Residuo & 29 & \\
\hline
\end{tabular}

$\mathrm{CV}=29,31 \%$

A incidência de nós nas tábuas variou significativamente, apenas entre espécies. Não houve diferença significativa entre toras e também não foi significativa a interação da tora com a espécie, demonstrando que ambas as toras apresentam o mesmo comportamento em todas as espécies.

A tabela 22 apresenta os resultados do teste de comparação múltipla de Bonferroni aplicado dos valores de Incidência média de nós, encontrados nas faces das tábuas das quinze espécies de eucaliptos. Observa-se que não existem diferenças significativas entre os subgêneros.

Tabela 22. Quantidade média de nós por subgênero, comparados pelo teste de Bonferroni.

\begin{tabular}{lcc}
\hline Causas de variação & Média de Nós & Grupo (1) \\
\hline Corymbia & 4,67 & a \\
Symphyomyrtus & 4,22 & a \\
Monocalyptus & 3,48 & a \\
ldiogenes & 2,99 & a \\
\hline
\end{tabular}

(1) Médias com a mesma letra não são significativamente diferentes entre si.

(2) $C V=45,33 \%$

A tabela 22 apresenta a comparação entre as médias, pelo teste de Bonferroni ao nivel de $5 \%$ de probabilidade, para a incidência média de nós por face de tábua na tora, mostrou que não existem diferenças significativas entre os subgêneros.

Verifica-se, dentro do gênero Eucalyptus, que o $E$. resinifera e o $E$. torelliana, que se caracterizam como as espécies mais nodosas, diferiram significativamente do grupo do $E$. citriodora do $E$. tereticornis e do $E$. cloeziana. As demais espécies formam subgrupos intermediários, que se interrelacionam ora com espécies de maior freqüência de nós e ora com espécies de menos nós, como apresentado na Tabela 23. 
Dentro do subgênero Symphyomyrtus, verifica-se que o $E$. resinifera apresenta uma incidência de nós, significativamente maior do que das demais espécie. As demais espécies formam dois subgrupos distintos encabeçados pelo $E$. microcorys e $E$. tereticornis respectivamente.

No subgênero Monocalyptus, as espécies apresentam a mesma incidência de nós, e não diferem significativamente entre si.

Tabela 23. Comparação da freqüência de nós por face de tábua, pelo teste de Bonferroni.

\begin{tabular}{|c|c|c|c|c|}
\hline Subgênero & Espécie & Nós & $\begin{array}{l}\text { Espécie dentro de } \\
\text { Subgênero (1) }\end{array}$ & $\begin{array}{c}\text { Espécies dentro } \\
\text { do gênero (1) }\end{array}$ \\
\hline Symphyomyrtus & $\begin{array}{l}\text { E. resinifera } \\
\text { E. microcorys } \\
\text { E. paniculata } \\
\text { E. urophylla } \\
\text { E. saligna } \\
\text { E. pellita } \\
\text { E. propinqua } \\
\text { E. tereticomis }\end{array}$ & $\begin{array}{l}7,75 \\
5,08 \\
4,96 \\
4,45 \\
4,00 \\
3,47 \\
3,24 \\
2,41\end{array}$ & $\begin{array}{l}a \\
b \\
b \\
b c \\
b c \\
b c \\
b c \\
c\end{array}$ & $\begin{array}{l}a \\
b c \\
b d c \\
\text { bdc } \\
\text { edc } \\
\text { edc } \\
\text { edc } \\
\text { ed }\end{array}$ \\
\hline Monocalyptus & $\begin{array}{l}\text { E. pilularis } \\
\text { E. phaeotricha } \\
\text { E. pyrocarpa }\end{array}$ & $\begin{array}{l}3,92 \\
3,35 \\
3,17\end{array}$ & $\begin{array}{l}a \\
a \\
a\end{array}$ & $\begin{array}{l}\text { edc } \\
\text { edc } \\
\text { edc }\end{array}$ \\
\hline Corymbia & $\begin{array}{l}\text { E. torelliana } \\
\text { E. maculata } \\
\text { E. citriodora }\end{array}$ & $\begin{array}{l}6,97 \\
5,20 \\
1,81\end{array}$ & $\begin{array}{l}a \\
a \\
c\end{array}$ & $\begin{array}{c}\mathrm{ba} \\
\mathrm{bac} \\
\mathrm{e}\end{array}$ \\
\hline Idiogenes & E. cloeziana & 2,98 & & edc \\
\hline
\end{tabular}

(1) Médias com a mesma letra não diferem estatisticamente entre si. $\quad C V=29,31 \%$

No subgênero Corymbia o E. torelliana e o E. maculata não diferem estatisticamente entre si, mas ambos diferem significativamente do $E$. citriodora, que é a espécie menos nodosa.

A Figura 20 apresenta a freqüência de tábuas sem nós nas 15 espécies de Eucalyptus. O E. citriodora e o E.cloeziana com $52,1 \%$ e $48,7 \%$ de tábuas sem nós, respectivamente, destacaram-se das demais como sendo as espécies de maior freqüência de tábuas sem nós. Podem ser consideradas como as espécies que mais facilmente promovem a auto-desrama. Opostamente a estas o E. microcorys apresentam $98,4 \%$ de tábuas com nós. 


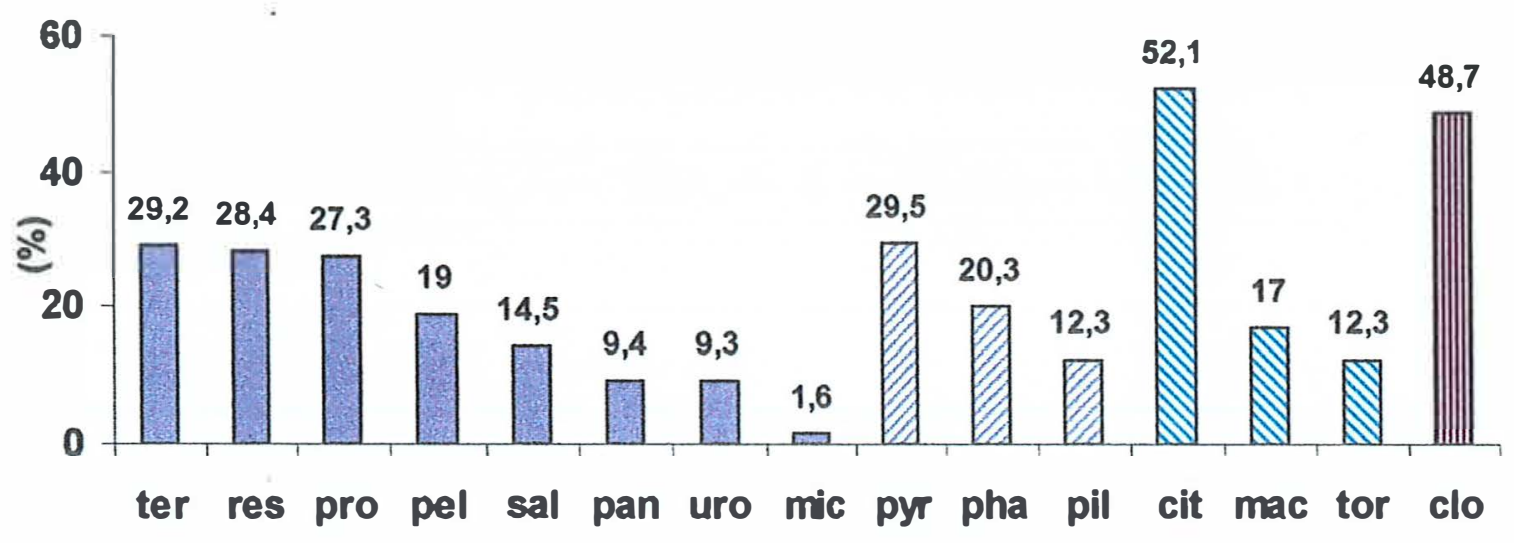

Figura 20 - Percentagem média de tábuas sem nós.

Os E. tereticomis, E. resinifera, E. propinqua e o E. pyrocarpa, produziram praticamente a mesma freqüência de tábuas sem nós, apesar de apresentarem significativas diferenças na incidência de nós. Isso significa que a distribuição de nós ao longo do diâmetro da tora pode ser tal que concentre maior quantidade de nós nas tábuas mais intemas e menor quantidade de nós nas tábuas mais externas.

A Figura 21 apresenta a quantidade média de nós por face de tábua nas 15 espécies de Eucalyptus e a Figura 22 mostra a freqüência média de nós em ambas as toras.

Sym phyomyrtus Monocalyptus

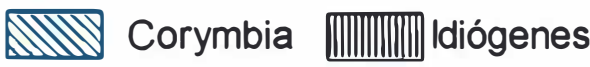

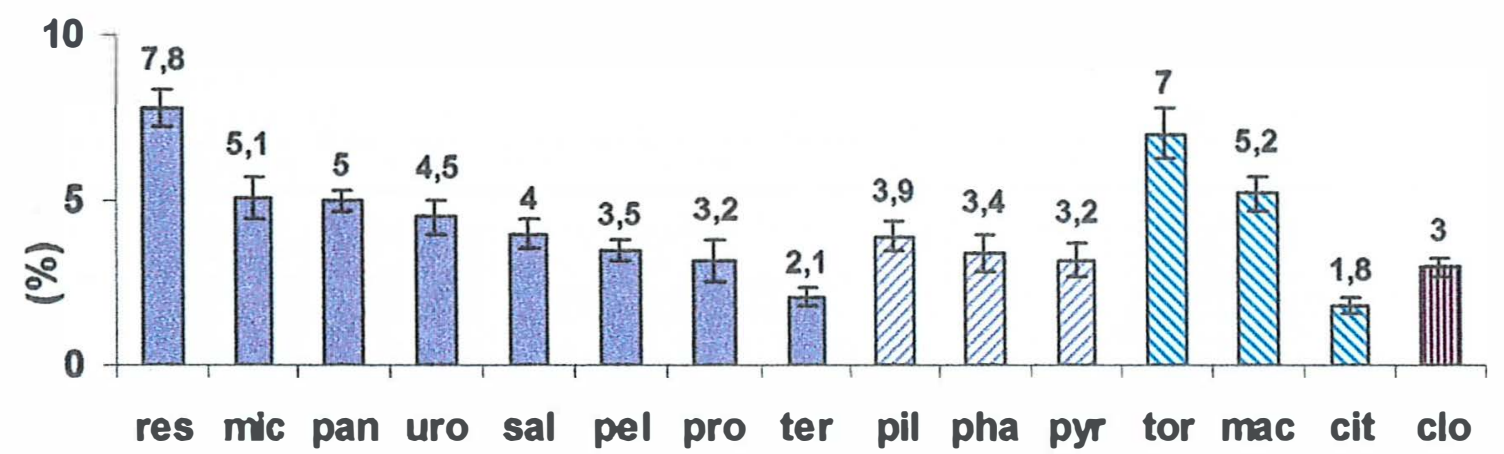

Figura 21 - Incidência média de nós por face de tábua, nas 15 espécies de Eucalyptus. 
A operação de desrama, além de evitar os indesejáveis nós na madeira, reduz $O$ ataque de fungos e insetos xilófagos na madeira, que freqüentemente iniciam 0 ataque nos ramos que estão perdendo o seu vigor.

Verifica-se na Figura 22, que a tora B ou a superior apresenta na maioria das espécies uma incidência de nós, ligeiramente maior do que na tora da base. A tora da base apresentou em média 9,9 nós por face de tábua e a tora subsequente apresentou 9,1 nós por face de tábua. Essa diferença não foi estatisticamente significativo.

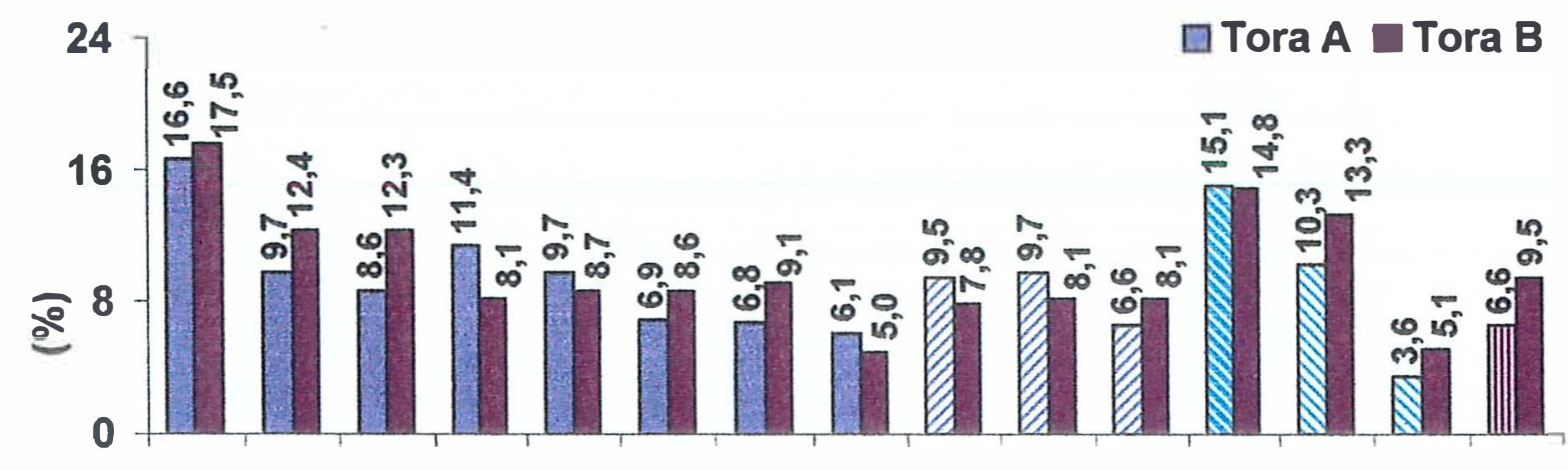

res mic pan sal uro pel pro ter pil pyr pha tor mac cit clo

Figura 22 - Incidência média de nós por face de tábua na tora da base (tora A) e na tora subsequente (tora B), nas 15 espécies de Eucalyptus.

Ponce (1996) afirma que o tamanho e a quantidade de nós na madeira, depende de sua posição na tora e das características da tora. As toras por sua vez, dependem de fatores genético da árvore que lhe dá origem, do espaçamento da floresta e do manejo a que foi submetida. Os galhos devem ser podados quando começam a morrer, até a altura desejada.

Quanto mais freqüente forem as intervenções no povoamento, logicamente, menores serão os diâmetros dos galhos, resultando num menor tempo de cicatrização, consequentemente, menor o risco do ataque de predadores.

A Figura 23 apresenta distribuição da freqüência média de nós por face de tábua ao longo do diâmetro das toras, no sentido casca medula casca, entre as espécies dos subgêneros de Eucalyptus. 

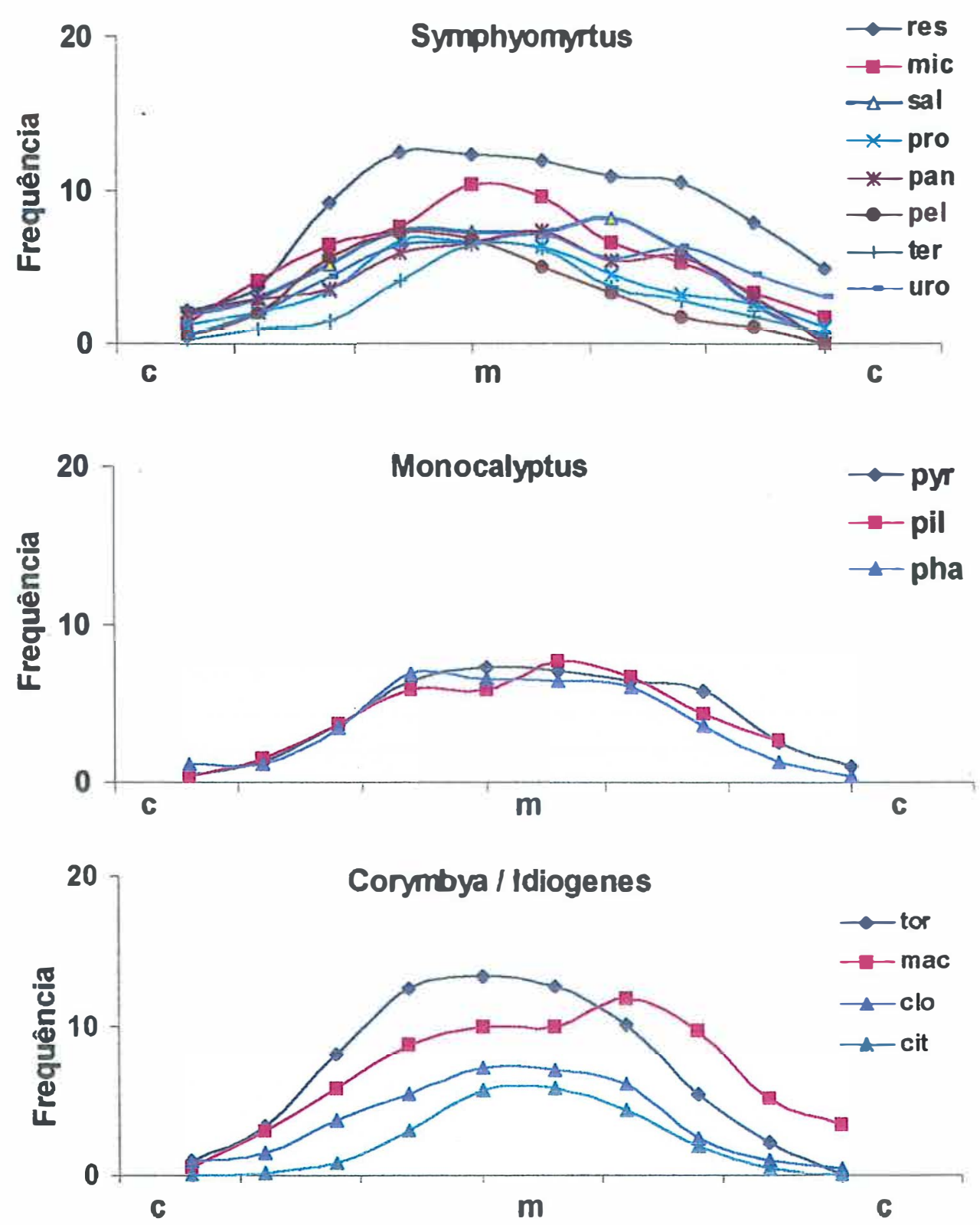

Figura 23 - Distribuição da freqüência média de nós por face, no sentido casca medula casca.

Observa-se nessa figura que o padrão de distribuição de nós, ao longo do diâmetro na árvore, é semelhante para todas as espécies. Ocorre maior intensidade na região da medula e uma diminuição gradativa na direção da casca. 
$\mathrm{Na}$ produção de madeira serrada e de chapas laminadas para certos usos, a homogeneidade das características da madeira e a ausência de nós, são fatores mais importantes do que a densidade básica ou rachaduras de extremidades de tábuas. O tamanho, a freqüência e o tipo de nó (vivo ou morto), afetam tanto a aparência e a resistência mecânica como a sua aceitação comercial da madeira produzida. Na produção de parquets por exemplo, a maior perda de madeira ocorre na eliminação dos nós, que são indesejáveis em pisos. Por este motivo, a produção de elevadas proporções de madeira limpa, sem nós, no tronco das árvores destinadas ao processamento mecânico, é condição determinante para o aprimoramento da sua qualidade e do seu valor. Com este propósito, a prática de poda cuidadosa é extremamente necessária e importante.

De acordo com Oliveira (1999), na produção de madeira para a serraria, os nós são indesejáveis, devendo ser eliminados por desrama, mesmo que parcial, logo no início do crescimento das árvores. Os investimentos feitos nesta operação são plenamente compensados pelas tábuas de qualidade superior e portanto melhor remuneradas. Sella (2001) afirma que dependendo do produto final, a valorização da tora desramada pode dobrar ou triplicar, melhorando a taxa interna de retorno e atingindo mercados mais interessantes e distantes da produção florestal. 


\section{6 indice de rachaduras (IR)}

A Tabela 24 apresenta as estatísticas descritivas dos valores obtidos, de rachaduras encontradas nas extremidades das tábuas, na condição verde, logo após o desdobro.

Tabela 24. Índice de rachadura de extremidade de tábua (IR).

\begin{tabular}{lcccccc}
\hline \multicolumn{1}{c}{ Espécie } & $\begin{array}{c}\text { Médio } \\
(\mathrm{cm})\end{array}$ & $\begin{array}{c}\text { Mínimo } \\
(\mathrm{cm})\end{array}$ & $\begin{array}{c}\text { Máximo } \\
(\mathrm{cm})\end{array}$ & $\mathrm{s}$ & CV $(\%)$ & $\mathrm{S}_{\mathrm{x}}^{-}$ \\
\hline E. pilularis & 36,28 & 23,41 & 74,23 & 19,16 & 52,78 & 7,82 \\
E. microcorys & 34,74 & 15,71 & 60,34 & 15,38 & 44,27 & 6,28 \\
E. tereticomis & 29,31 & 11,37 & 50,83 & 13,98 & 47,69 & 5,71 \\
E.cloeziana & 29,09 & 18,93 & 43,30 & 8,68 & 29,84 & 3,54 \\
E. phaeotricha & 28,71 & 8,15 & 46,67 & 13,46 & 46,88 & 5,49 \\
E. paniculata & 26,82 & 9,50 & 59,86 & 19,70 & 73,45 & 8,04 \\
E. propinqua & 25,27 & 9,75 & 36,42 & 9,52 & 37,67 & 3,89 \\
E. urophylla & 23,03 & 1,54 & 54,54 & 22,53 & 97,83 & 9,20 \\
E. pyrocarpa & 21,82 & 11,25 & 34,92 & 9,10 & 41,7 & 3,72 \\
E. saligna & 17,41 & 7,50 & 29,18 & 7,28 & 41,81 & 2,97 \\
E. maculata & 16,52 & 3,15 & 38,92 & 13,07 & 79,12 & 5,57 \\
E. citriodora & 15,29 & 4,38 & 36,92 & 14,21 & 92,93 & 5,80 \\
E. pellita & 15,03 & 0,01 & 54,18 & 20,21 & 134,46 & 8,25 \\
E. resinifera & 13,01 & 4,21 & 26,00 & 9,77 & 75,10 & 3,99 \\
E. torelliana & 6,67 & 0,73 & 18,34 & 6,01 & 90,10 & 2,45 \\
\hline
\end{tabular}

$s=$ Desvio Padrão

$C V=$ Coeficiente de variação

$S_{\bar{x}}=$ Erro Padrão da Média

Verifica-se na Tabela 24 que a espécie E. pilularis apresentou o maior índice de rachadura médio $(36,28 \mathrm{~cm})$, sugerindo que esta espécie é a menos indicada para utilização em serraria, como produtora de madeira serrada. Entretanto, Pasztor (1972) afirma que esta é a principal espécie usada em serrarias da Nova Gales do Sul e do sul de Queensland, sendo a madeira serrada muito empregada na construção civil.

A seguir aparecem as espécies $E$. microcorys com IR de $34,74 \mathrm{~cm}, E$. tereticornis com IR de $29,83 \mathrm{~cm}$, E.cloeziana com IR de $29,09 \mathrm{~cm}$ e o $E$. phaeotricha com IR de $28,71 \mathrm{~cm}$.

O E. toreliana apresentou o menor índice de rachadura médio $(6,67$ $\mathrm{cm}$ ), sugerindo ser a melhor espécie para o desdobro, pois apresentou a menor 
perda de madeira, em conseqüência das rachaduras de extremidades das tábuas. $O$ valor mínimo de $\mathrm{IR}$ igual a $0,01 \mathrm{~cm}$ encontrado em uma tora de $E$. pellita indica grande variabilidade entre as árvores dessa espécie apresentando, portanto, um grande potencial para seleção.

Miranda (1997) obteve para um plantio de E. saligna, de diâmetro médio de $25,2 \mathrm{~cm}$, um índice de rachaduras de extremidade de tábuas de 9,54 $\mathrm{cm}$. Esse índice é inferior ao do E. saligna com de diâmetro médio de $35,03 \mathrm{~cm}$, do presente estudo $(13,02 \mathrm{~cm})$. Uma das causas daquele menor índice de rachaduras, foi a menor largura média das tábuas $(12,43 \mathrm{~cm})$, sensivelmente inferior à largura média das tábuas do presente estudo, que foi de $19,28 \mathrm{~cm}$.

Os coeficientes de variação (CV) dos índices de rachaduras foram extremamente elevados, o que demonstra grande variabilidade desse índice entre e dentro de espécies. $O$ menor $C V$ obtido foi o do $E$. cloeziana, que apresentou o valor de $29,09 \%$.

Tabela 25. Análise de variância do índice de rachaduras de extremidade de tábua.

\begin{tabular}{lcc}
\hline Causa de variação & $\mathrm{GL}$ & $\mathrm{Pr}>\mathrm{F}$ \\
\hline Espécie $(E)$ & 14 & 0,0107 \\
Toras $(T)$ & 1 & 0,2089 \\
E XT & 14 & 0,9654 \\
Resíduo & 29 & \\
\hline
\end{tabular}

$\mathrm{CV}=67,5 \%$

Verifica-se na tabela 25 , que houve diferenças significativas entre espécies e não houve diferenças significativas entre toras, demonstrando que ambas as toras apresentam a mesma intensidade de rachaduras. A interação da espécie com a tora também não foi significativa, demonstrando que esse comportamento vale igualmente para todas as espécies.

A comparação entre as médias das rachaduras, pelo teste de Bonferroni ao nivel de $5 \%$ de probabilidade, mostrou que existem diferenças significativas entre os subgêneros (Tabela 26). 0 Idiogenes e 0 
Monocalyptus, que apresentam os maiores índices de rachaduras, não diferem significativamente entre si mas diferem significativamente do Corymbia. O Symphyomyrtus não difere significativamente nem do Corymbia e nem dos outros dois.

Tabela 26. Índice de rachaduras de extremidade de tábua.

\begin{tabular}{lcc}
\hline Causa de variação & Rachadura média (cm) & Grupo (1) \\
\hline Idiogenes & 29,25 & a \\
Monocalyptus & 28,94 & a \\
Symphyomyrtus & 23,14 & ba \\
Corymbia & 12,85 & b \\
\hline
\end{tabular}

(1) Médias com a mesma letra não são significativamente diferentes entre si.

(2) $\mathrm{CV}=36.47 \%$

Em quase todas as tábuas de todas as espécies de Eucalyptus analisadas, foram observadas rachaduras nas extremidades de tábuas, de maior ou menor intensidade. As tábuas que apresentaram os maiores problemas de rachaduras foram aquelas localizadas próximas à medula, principalmente as tábuas diametrais. Essas rachaduras são facilitadas pelos sentidos opostos das tensões. Na borda da tábua as tensões são de tração e na região da medula as tensões são de compressão. Estas duas se transformam em tensões transversais com maior intensidade nas tábuas próximas à medula. Segundo Garcia (1995), o topo da tábua se transforma de superfície reta, para uma forma de calota, convexa. Na região da medula existe maior proporção de lenho juvenil, que é constituído de material de baixa resistência mecânica, facilitando assim o fendilhamento localizado.

Verifica-se na Tabela 27 que a comparação de médias de rachaduras de extremidade de tábua, pelo teste de Bonferroni ao nível de 5 \% de significância, dentro dos subgêneros, revelou que as espécies que compreendem o Symphyomyrtus não diferem significativamente entre si. 0 mesmo acontece para os subgêneros Corymbia e Monocalyptus. 
Os resultados do teste de Bonferroni apresentados na Tabela 27 acusou diferenças significativas entre as médias de espécies dentro do gênero. $O E$. torelliana com 0 menor $I R$, difere estatisticamente do $E$. microconys e do $E$. pilularis. O restante das espécies apresentam um mesmo padrão de rachaduras, não diferindo, de modo significativo, entre si.

A não significância do $\mathbb{I R}$ entre espécies está atrelada à grande variabilidade observada dentro das espécies onde muitos resultados se sobrepõe e superam a variação entre espécies. Uma das grandes causas de variação é a posição da tábua dentro da tora.

Tabela 27. Comparação das médias de rachaduras, nas quinze espécies e subgêneros.

\begin{tabular}{|c|c|c|c|c|}
\hline Subgênero & Espécies & $\begin{array}{c}\mathrm{IR} \\
(\mathrm{cm})\end{array}$ & $\begin{array}{c}\text { Espécies dentro de } \\
\text { subgênero (1) }\end{array}$ & $\begin{array}{c}\text { Espécies dentro do } \\
\text { gênero (1) }\end{array}$ \\
\hline \multirow{7}{*}{ Symphyomyrtus } & $\begin{array}{l}\text { E. microcorys } \\
\text { E. tereticomis }\end{array}$ & $\begin{array}{l}34,74 \\
29,31\end{array}$ & a & a \\
\hline & E. paniculata & 26,82 & a & ba \\
\hline & E. propinqua & 25,27 & a & ba \\
\hline & E. urophylla & 23,03 & a & ba \\
\hline & E. saligna & 17,41 & a & ba \\
\hline & E. pellita & 15,03 & a & ba \\
\hline & E. resinifera & 13,01 & a & ba \\
\hline \multirow{3}{*}{ Monocalyptus } & E. pilularis & 36,28 & a & a \\
\hline & E. phaeotricha & 28,71 & a & ba \\
\hline & E. pyrocarpa & 21,82 & a & ba \\
\hline \multirow{3}{*}{ Corymbia } & E. maculata & 16,52 & a & ba \\
\hline & E. citriodora & 15,29 & a & ba \\
\hline & E. torelliana & 6,67 & a & $b$ \\
\hline Idiogenes & E. cloeziana & 29,09 & & ba \\
\hline
\end{tabular}

(1) Médias com a mesma letra não diferem estatisticamente entre si.

Das espécies trabalhadas no presente estudo, o $E$. toreliana apresentou 0 melhor desempenho em termos de rachaduras, que associados a sua boa produtividade, torna esta espécie muito promissora para utilização na indústria moveleira e outros usos na construção civil. 
A Figura 24 apresenta o índice de rachadura de extremidade de tábua, obtidas para as quinze espécies de Eucalyptus.

Symphyomyrtus WIItrt Monocalyptus $\mathbb{M}$ Corymbia

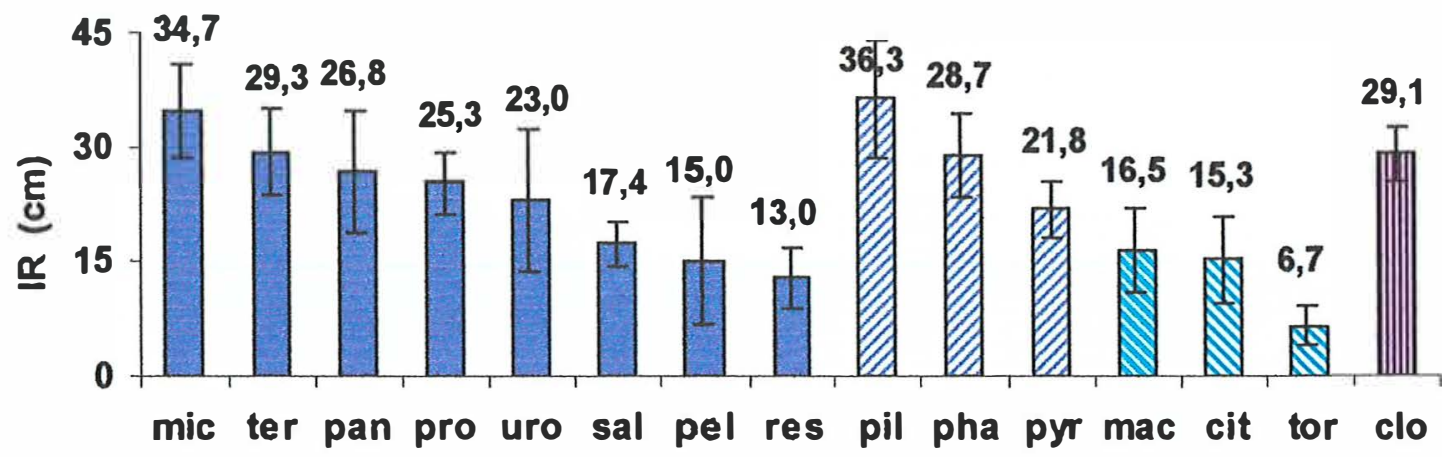

Figura 24 - Índice médio de rachaduras de extremidade das tábuas.

O E. pellita apresentou um dos mais baixos índices de rachadura, mas mostrou o maior coeficiente de variação, que foi de $134,46 \%$. A Figura 25 mostra que $\circ E$. pellita e $\circ E$. torelliana apresentaram as menores percentagens de tábuas rachadas, $24,0 \%$ e $35 \%$, respectivamente. Essas espécies juntamente com $\circ E$. citriodora e $\circ E$. urophylla formam um grupo de grande potencial de seleção. Em contrapartida, o E. phaeotricha E. microcorys e o E. cloeziana são as espécies que apresentaram as maiores percentagens de tábuas rachadas.

Symphyomyrtus $217 x$ Monocalyptus

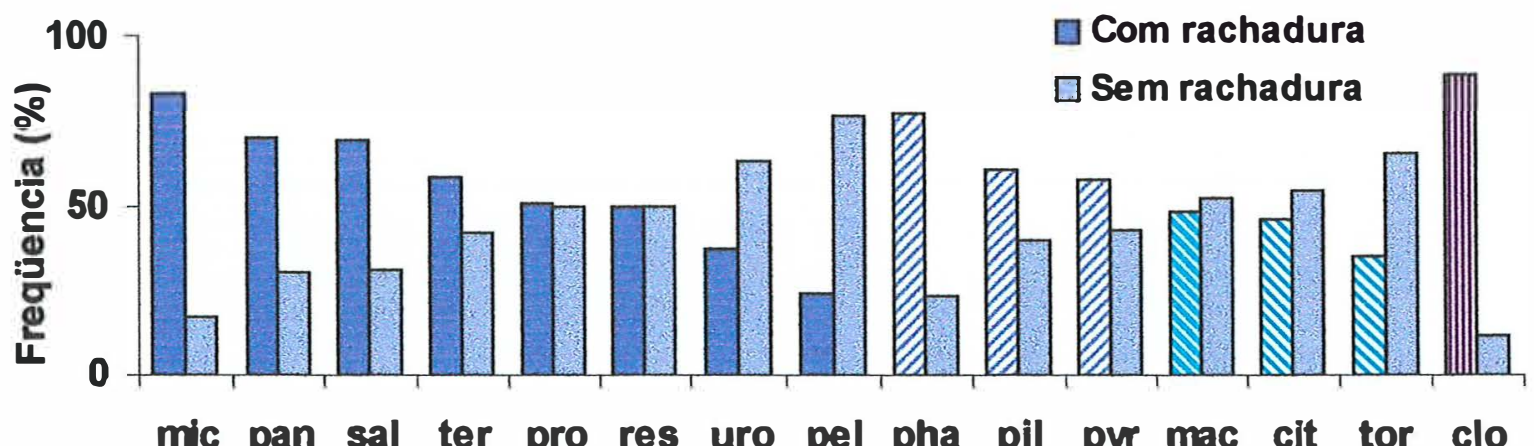

Figura 25 - Freqüência de tábuas com e sem rachaduras, das 15 espécies de Eucalyptus. 
O E. microcorys e o E. pilularis apresentaram uma grã muito espiralada, implicando em deformações da tora no desdobro. Para sua utilização em serraria, é necessário um melhoramento para essa característica. Estas espécies são mais indicadas para serem utilizadas como peças roliças como postes e moirões, ou peças maciças, simétricas em relação à medula como os dormentes.

O E. urophylla apresentou um desempenho desuniforme nas rachaduras, resultando no CV de $97,83 \%$, considerado muito alto. Três toras apresentaram altos indices de rachaduras com 44,0 cm, 54,53 e 44,00 cm em média por tora, que ocasionou um aumento na média da espécie e uma perda na produtividade em madeira serrada. As outras três toras apresentaram os menores índices de rachaduras por tora com $8,57 \mathrm{~cm}, 2,55 \mathrm{~cm}$ e 1,54 cm.

No processo de desdobro das toras as rachaduras de extremidades tendem a aumentar. Garcia (1997), serrando toras de E. urophylla utilizando uma serra fita dupla seguida de uma serra múltipla para aliviar as tensões de crescimento de forma balanceada, observou que ocorre uma redução no comprimento das peças serradas, devido às rachaduras de extremidades de tábuas, sendo muito comum ter-se uma perda média de $23 \mathrm{~cm}$ no comprimento total da peça.

O E. cloeziana apresentou um alto índice de rachaduras $(29,25 \mathrm{~cm})$ de comportamento uniforme, com o mais baixo coeficiente variação $(29,80 \%)$. 0 E. phaeotricha e $\circ E$. tereticornis apresentaram um comportamento muito semelhante com altos indices de rachaduras e CV de 46,88 e 47,80\% respectivamente, maiores que o do $E$. cloeziana. Isso demonstra que estas espécies são, em geral, possuidoras de altos niveis de tensões residuais nas toras.

As rachaduras são os defeitos mais freqüentes e os mais visiveis, desvalorizam a madeira serrada, influenciando no comprimento e/ou largura de cada peça. A maioria dos eucaliptos apresentam este defeito, sendo 
algumas espécies mais suscetiveis do que outras. A perda de madeira serrada de eucalipto devido às rachaduras de extremidade de tábua varia de 7 a $12 \%$, dependendo do comprimento da tora processada.

Conforme discorridas na revisão bibliográfica as rachaduras de extremidade de tábua são os principais problemas que acontecem com a madeira logo após o desdobro. Inúmeros estudos têm sidos realizados para tentar-se compreender e contornar esse problema. Analisando as perdas ocasionadas pelas rachaduras verificou-se uma tendência de redução do rendimento em madeira serrada na proporção em que elas aumentam.

Eymphyomyrtus - Corymbia Monocalyptus

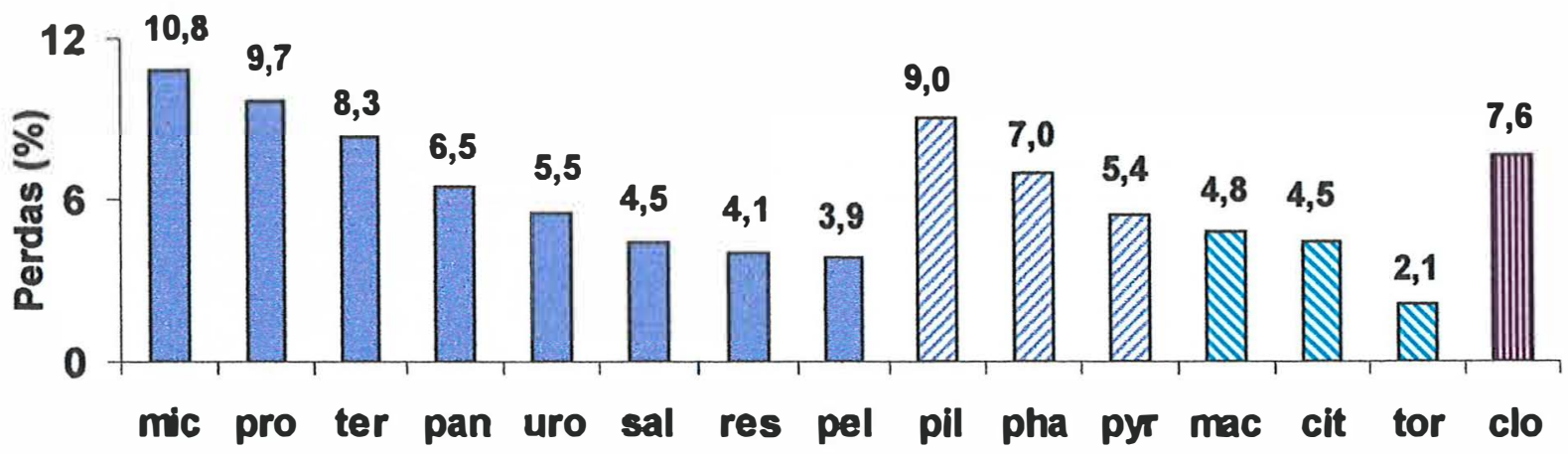

Figura 26 - Perdas em volume de madeira serrada, como conseqüência das rachaduras de extremidade das tábuas.

As perdas computadas na Figura 26 se referem àquelas ocasionadas por destopos impostas pelas rachaduras de extremidades das tábuas. Nesse estudo não foi considerado nenhum reaproveitamento secundários das tábuas, - que ocasionaria uma ligeira queda nessas perdas que são realmente consideráveis.

A figura 27 apresenta 0 índice de rachadura em três diferentes alturas no fuste da árvore, nas quinze espécies de Eucalyptus, separadas por subgêneros. 

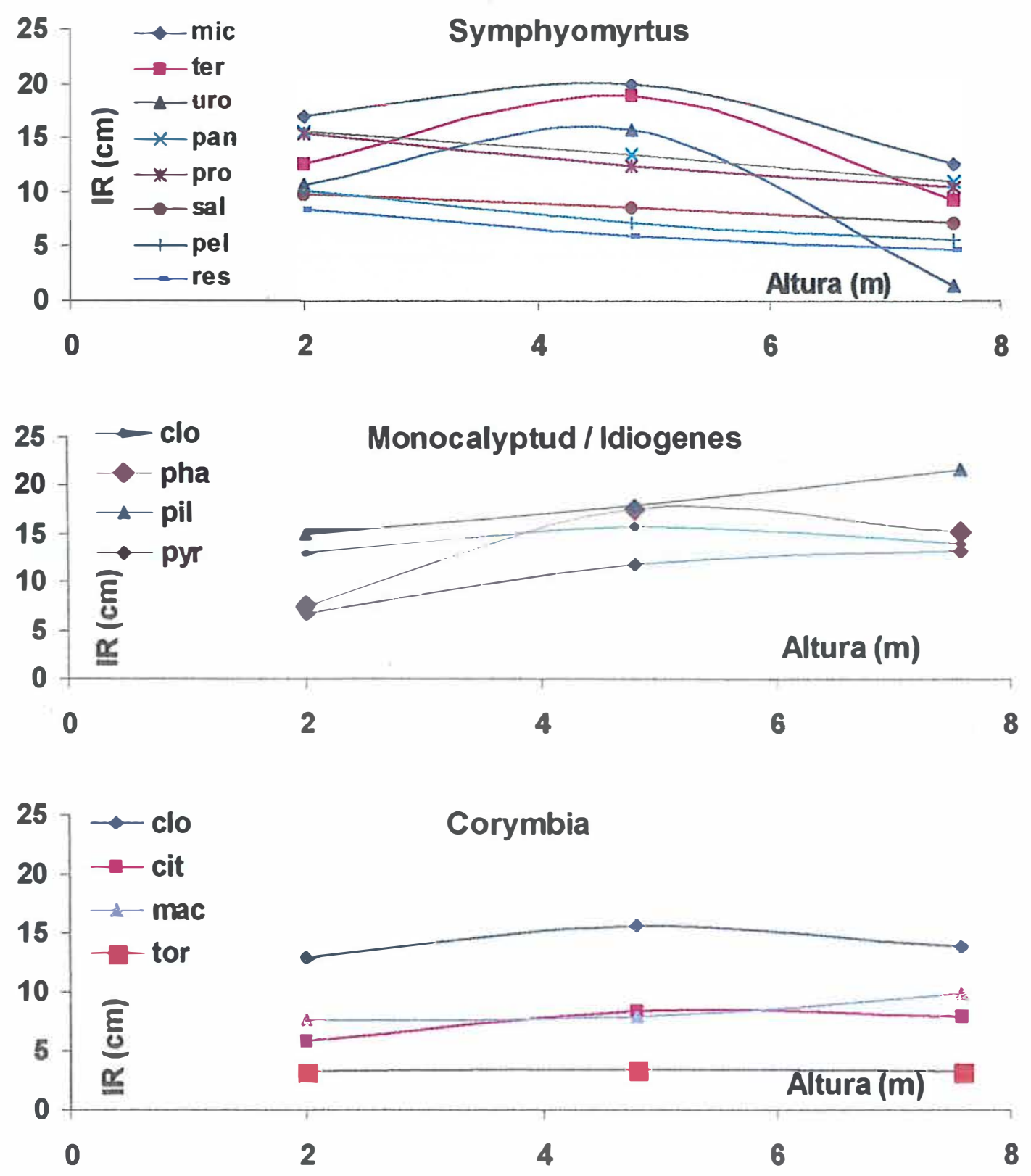

Figura 27 - Rachaduras de extremidades de tábua em função da altura na árvore.

As espécies do subgênero Symphyomyrtus apresentaram uma tendência de diminuir as rachaduras com o aumento da altura no tronco da árvore. Entre as espécies que diminuiram as rachaduras no sentido base topo, em ordem decrescente e não diferindo estatisticamente entre si, estão o $E$. paniculata, E. propinqua, E. saligna, E. pellita e por ultimo o E. resinifera. 
Comportamento inverso ocorreu com o E. urophylla, cuja rachadura aumentou significativamente da base para o topo da primeira tora onde apresentou uma média de $15,80 \mathrm{~cm}$. Depois decresceu acentuadamente até o valor médio de $1,41 \mathrm{~cm}$ de rachadura, na altura de 7,60 $\mathrm{m}$ na árvore. Comportamento semelhante a este também ocorreu no $E$. tereticornis, $E$. microconys, mas com médias mais baixas de rachaduras no topo da segunda tora.

Dentro do subgênero Symphyomyrtus o E. urophylla, E. microcorys e o E. tereticornis apresentaram um comportamento notadamente diferente das demais espécies (Figura 27). Segundo Ferreira (2000), em comunicação pessoal, essas 3 espécies são de clima tropical e de baixa altitude, enquanto que as outras 5 restantes são de clima subtropical.

No subgênero Monocalyptus, o E. pilularis destacou-se como a espécie de maior taxa de crescimento do índice de rachadura com o aumento da altura na árvore, apresentando rachadura média de $21,69 \mathrm{~cm}$ a $7,60 \mathrm{~m}$ de altura. $O E$. pyrocarpa apresentou o mesmo comportamento, mas com menor intensidade de rachadura. No E. phaeotricha, que também é uma espécie de clima tropical, as rachaduras aumentaram significativamente da base para o topo da primeira tora, voltando a decrescer na tora seguinte.

No subgênero Corymbia observou-se um comportamento mais estável nas rachaduras. O E. toreliana, além de apresentar o menor índice de rachadura, apresentou um comportamento uniforme, ou seja, o índice de rachadura não variou com a altura na árvore, com valores médios de $3,21 \mathrm{~cm}$, 3,43 e $3,29 \mathrm{~cm}$, como mostra a Figura 27 . O E.citriodora comportou-se de maneira semelhante, mas com índices superiores e mais heterogêneos. $O E$. maculata apresentou um comportamento intermediário entre o Corymbia e o Monocalyptus, tendendo a aumentar as rachaduras da base para o topo, mas de forma moderada. 


\subsection{Encurvamento (Flecha)}

Os encurvamentos são indicadores indiretos das tensões de crescimento. Desqualifica a madeira e reduz o seu valor comercial. Nas especificações de qualidade, são admitidas flechas de até $5 \mathrm{~mm}$ na classe extra e de até $10 \mathrm{~mm}$ nas classes primeira e segunda. De acordo com os dados da Tabela 28 , os eucaliptos estão situados entre as classes segunda e terceira. Entretanto, os encurvamentos geralmente são corrigido na secagem e pode ser corrigidos no momento de utilização das tábuas.

Verifica-se na Tabela 28 que o E. microcorys, E.cloeziana e o $E$. paniculata apresentaram os maiores encurvamentos, com valores médios de $12,87,11,77$ e 10,25 $\mathrm{mm}$ respectivamente, medidos em tábuas de $2,80 \mathrm{~m}$ de comprimento.

As espécies que apresentaram os menores encurvamentos foram o $E$. citriodora, E. urophylla e o E. toreliana com valores de, respectivamente, 5,33; 5,76 e $6,37 \mathrm{~mm}$ de flecha por tábua.

Tabela 28. Encurvamento médio em tábuas de 2,80 $\mathrm{m}$ de comprimento.

\begin{tabular}{lcccccc}
\hline Espécie & $\begin{array}{c}\text { Médio } \\
(\mathrm{mm})\end{array}$ & $\begin{array}{c}\text { Mínimo } \\
(\mathrm{mm})\end{array}$ & $\begin{array}{c}\text { Máximo } \\
(\mathrm{mm})\end{array}$ & $\mathbf{s}$ & $\begin{array}{c}\text { CV } \\
(\%)\end{array}$ & $\mathrm{S}_{\mathrm{x}}^{-}$ \\
\hline E. microcorys & 12,87 & 7,64 & 17,11 & 4,17 & 32,4 & 1,70 \\
E. cloeziana & 11,77 & 8,92 & 16,70 & 3,2 & 27,2 & 1,31 \\
E. paniculata & 10,25 & 5,25 & 21,83 & 6,02 & 58,7 & 2,46 \\
E. pyrocarpa & 10,14 & 8,20 & 12,50 & 1,70 & 16,8 & 0,7 \\
E. phaeotricha & 8,92 & 6,86 & 10,91 & 1,45 & 16,3 & 0,59 \\
E. pilularis & 8,39 & 5,92 & 10,89 & 1,63 & 19,4 & 0,66 \\
E. tereticomis & 8,24 & 6,33 & 10,42 & 1,72 & 20,9 & 0,70 \\
E. pellita & 7,79 & 6,22 & 9,36 & 1,37 & 17,6 & 0,56 \\
E. propinqua & 7,41 & 3,80 & 9,75 & 2,58 & 34,9 & 1,05 \\
E. saligna & 7,15 & 5,25 & 8,17 & 1,07 & 14,9 & 0,43 \\
E. maculata & 6,65 & 3,50 & 10,46 & 2,36 & 35,5 & 0,96 \\
E. resinifera & 6,57 & 3,67 & 11,55 & 3,03 & 46,2 & 1,24 \\
E. torelliana & 6,37 & 4,00 & 8,23 & 1,64 & 25,9 & 0,67 \\
E. urophylla & 5,76 & 3,46 & 9,89 & 2,30 & 40,0 & 0,94 \\
E. citriodora & 5,33 & 4,50 & 6,80 & 0,89 & 16,7 & 0,36 \\
\hline S = Desvio padrão & CV Coeficiente de variação & $S_{\mathbf{x}}^{-}=$Erro Padrão da Média &
\end{tabular}


Embora $\circ E$. pilularis tenha apresentado encurvamento relativamente pequeno $(8,39 \mathrm{~mm})$, foi a espécie que, como mostra a Tabela 24 , apresentou 0 maior índice de rachadura $(36,28 \mathrm{~mm})$. O E. paniculata e o E. microcorys foram as espécies que apresentaram as maiores média de encurvamento numa de suas toras, com 21,83 e 17,11 mm, respectivamente.

Lima (2000) verificou diferenças significativas de encurvamentos de peças serradas entre as diferentes intensidades de desbastes. $\mathrm{Na}$ intensidade de desbaste de $83 \%$, o valor do encurvamento foi de $7,22 \mathrm{~mm}$ e na intensidade de $0 \%$ de desbaste o encurvamento foi de $10,73 \mathrm{~mm}$, ambas medidas em tábuas de 2,5 m de comprimento. Nas demais intensidades de desbastes não houve diferenças significativas de encurvamentos.

A Tabela 29 apresenta a análise de variância aplicada aos valores de encurvamento médio medido nas tábuas, das 15 espécies de Eucalyptus, Imediatamente após o desdobro.

Tabela 29. Análise da variância dos encurvamentos médios.

\begin{tabular}{lrl}
\hline Causas de variação & GL & $\mathrm{Pr}>\mathrm{F}$ \\
\hline Espécie & 14 & 0,0002 \\
Toras & 1 & 0,0597 \\
Esp X Tor & 14 & 0,9664 \\
Residuo & 29 & \\
\hline \multicolumn{1}{c}{ CV $=33,74 \%$} & &
\end{tabular}

Observa-se nessa Tabela 29 houve diferenças significativas entre espécies e toras. Os empenamentos foram maiores na primeira tora da árvore. $A$ interação da espécie com a tora não foi significativa demonstrando que a diminuição do encurvamento da tora A para a tora B segue o mesmo padrão em todas as espécies.

A comparação entre as médias de encurvamento, pelo teste de Bonferroni ao nível de $5 \%$ de probabilidade, na Tabela 30 , mostrou que existem diferenças significativas entre os subgêneros. $O$ Idiogenes, onde 0 
encurvamento foi maior diferiu significativamente do Symphyomyrtus e do Corymbia. O Monocalyptus se assemelha aos outros três subgêneros.

Tabela 30. Comparação dos encurvamentos das tábuas nos subgêneros.

\begin{tabular}{lcc}
\hline Causas de variação & Encurvamento médio & Grupo (1) \\
\hline Idiogenes & 11,77 & $\mathrm{a}$ \\
Monocalyptus & 9,11 & $\mathrm{ab}$ \\
Symphyomyrtus & 8,25 & $\mathrm{~b}$ \\
Corymbia & 6,12 & $\mathrm{~b}$
\end{tabular}

(1) Médias com a mesma letra não são significativamente diferentes. $\quad C V=36,60 \%$

A Tabela 31 mostra que dentro do subgênero Symphyomyrtus $O E$. microcorys difere significativamente do E. urophylla. No subgênero Monocalyptus e Corymbia as espécies não diferem significativamente entre si.

Tabela 31. Encurvamentos nas quinze espécies de Eucalyptus, pelo teste de Bonferroni

\begin{tabular}{|c|c|c|c|c|}
\hline Subgênero & $\begin{array}{l}\text { Causas de } \\
\text { variação }\end{array}$ & $\begin{array}{l}\text { Flecha } \\
(\mathrm{mm})\end{array}$ & $\begin{array}{l}\text { Espécies dentro de } \\
\text { subgênero (1) }\end{array}$ & $\begin{array}{c}\text { Espécies dentro } \\
\text { do gênero (1) }\end{array}$ \\
\hline Symphyomyrtus & $\begin{array}{l}\text { E. microcorys } \\
\text { E. paniculata } \\
\text { E. tereticornis } \\
\text { E. pelita } \\
\text { E. propinqua } \\
\text { E. saligna } \\
\text { E. resinifera } \\
\text { E. urophylla }\end{array}$ & $\begin{array}{c}12,87 \\
10,25 \\
8,24 \\
7,79 \\
7,41 \\
7,15 \\
6,57 \\
5,76\end{array}$ & $\begin{array}{c}a \\
a b \\
a b \\
a b \\
a b \\
a b \\
a b \\
b\end{array}$ & $\begin{array}{c}\text { a } \\
\text { bac } \\
\text { bac } \\
\text { bac } \\
\text { bac } \\
\text { bc } \\
\text { bc } \\
\text { bc }\end{array}$ \\
\hline Monocalyptus & $\begin{array}{l}\text { E. pyrocarpa } \\
\text { E. phaeotricha } \\
\text { E. pilularis }\end{array}$ & $\begin{array}{l}10,14 \\
8,92 \\
8,38\end{array}$ & $\begin{array}{l}a \\
a \\
a\end{array}$ & $\begin{array}{l}\text { bac } \\
\text { bac } \\
\text { bac }\end{array}$ \\
\hline Corymbia & $\begin{array}{l}\text { E. maculata } \\
\text { E. toreliana } \\
\text { E. citriodora }\end{array}$ & $\begin{array}{l}6,65 \\
6,37 \\
5,33\end{array}$ & $\begin{array}{l}a \\
a \\
a\end{array}$ & $\begin{array}{c}\mathrm{bc} \\
\mathrm{bc} \\
\mathrm{c}\end{array}$ \\
\hline Idiogenes & E. cloeziana & 11,77 & & ba \\
\hline
\end{tabular}

(*) Médias com a mesma letra não diferem estatisticamente entre si.

Dentro do gênero de Eucalyptus o E. microcorys e o E. cloeziana apresentam os maiores encurvamentos, diferiram do $E$. citriodora que apresentou o menor encurvamento. Todas as demais espécies formam um 
grupo intermediário, não diferindo significativamente entre si. A Figura 28 resume a discussão efetuada acima.

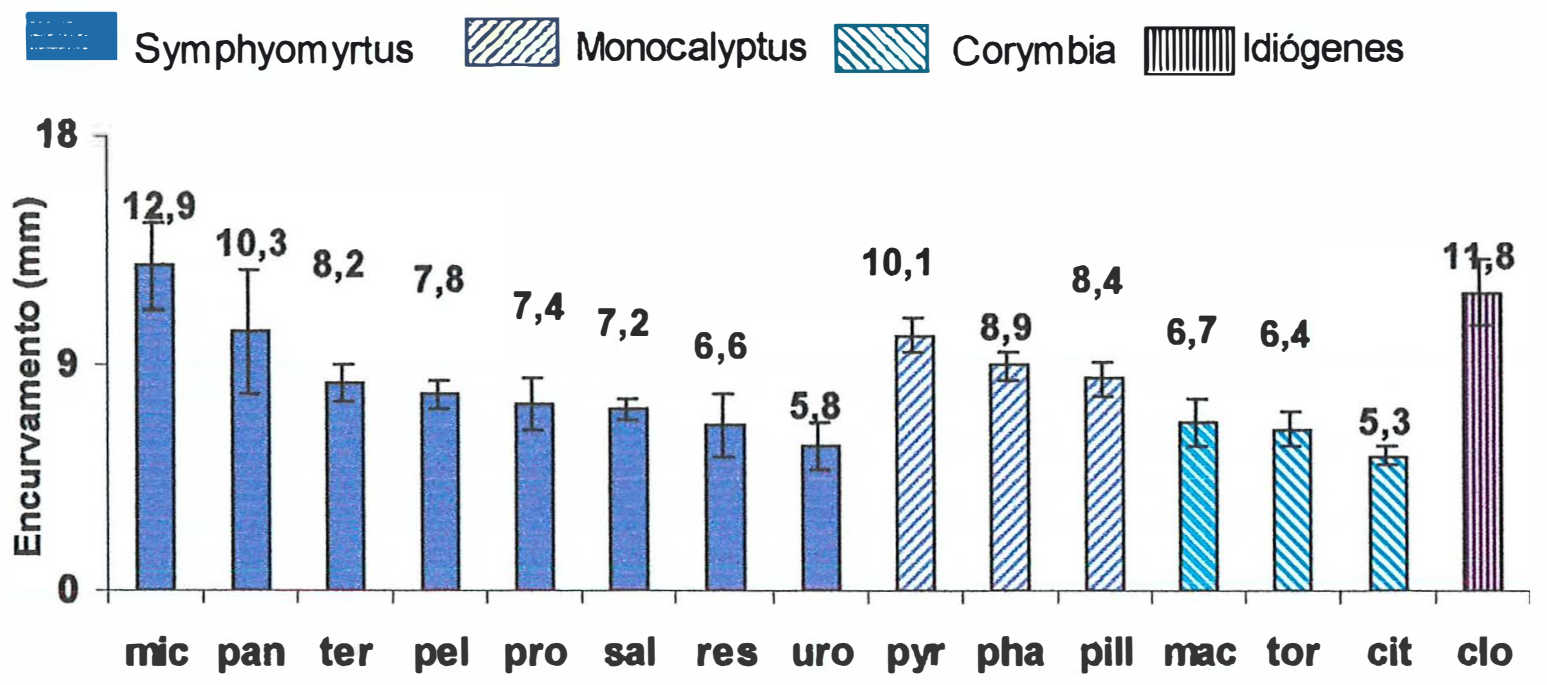

Figura 28 - Encurvamentos das 15 espécies de Eucalyptus.

Miranda (1997) estudando três espaçamentos de plantio, observou que a média dos encurvamentos para as tábuas, nos tratamentos foi de 3,94 $\mathrm{mm} / \mathrm{m}$.

Schacht (1998) estudando 10 clones de E. urophylla, não encontrou diferenças significativas de encurvamentos, para o vigote da costaneira nas alturas de 3,1 m e 6,5 m no fuste da árvore. As média variaram de 2,7 cm até $5,49 \mathrm{~cm}$ e uma média de $4,38 \mathrm{~cm}$ em tábuas de 3,4 $\mathrm{m}$ de comprimento.

A Figura 29 apresenta a variação das rachaduras e dos encurvamentos ao longo do diâmetro da tora, das quinze espécies de eucaliptos. Todas as espécies apresentaram um comportamento assimétrico similar, com maiores intensidades de encurvamentos nas tábuas próximas à casca, sendo que nas tábuas de lado oposto, próximo ao início do desdobro, os encurvamentos são menores do que aqueles verificados nas tábuas obtidas no início do desdobro. 

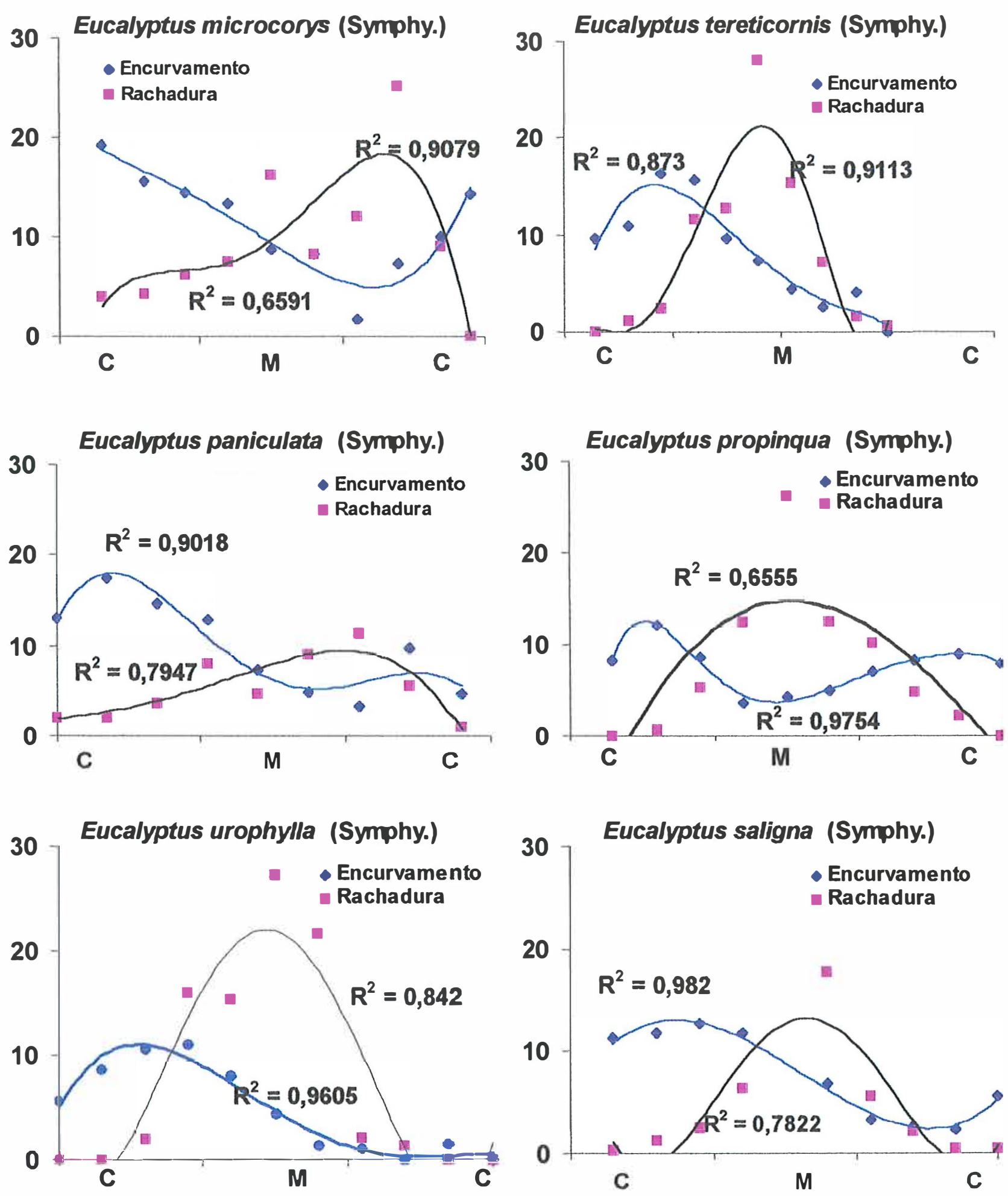

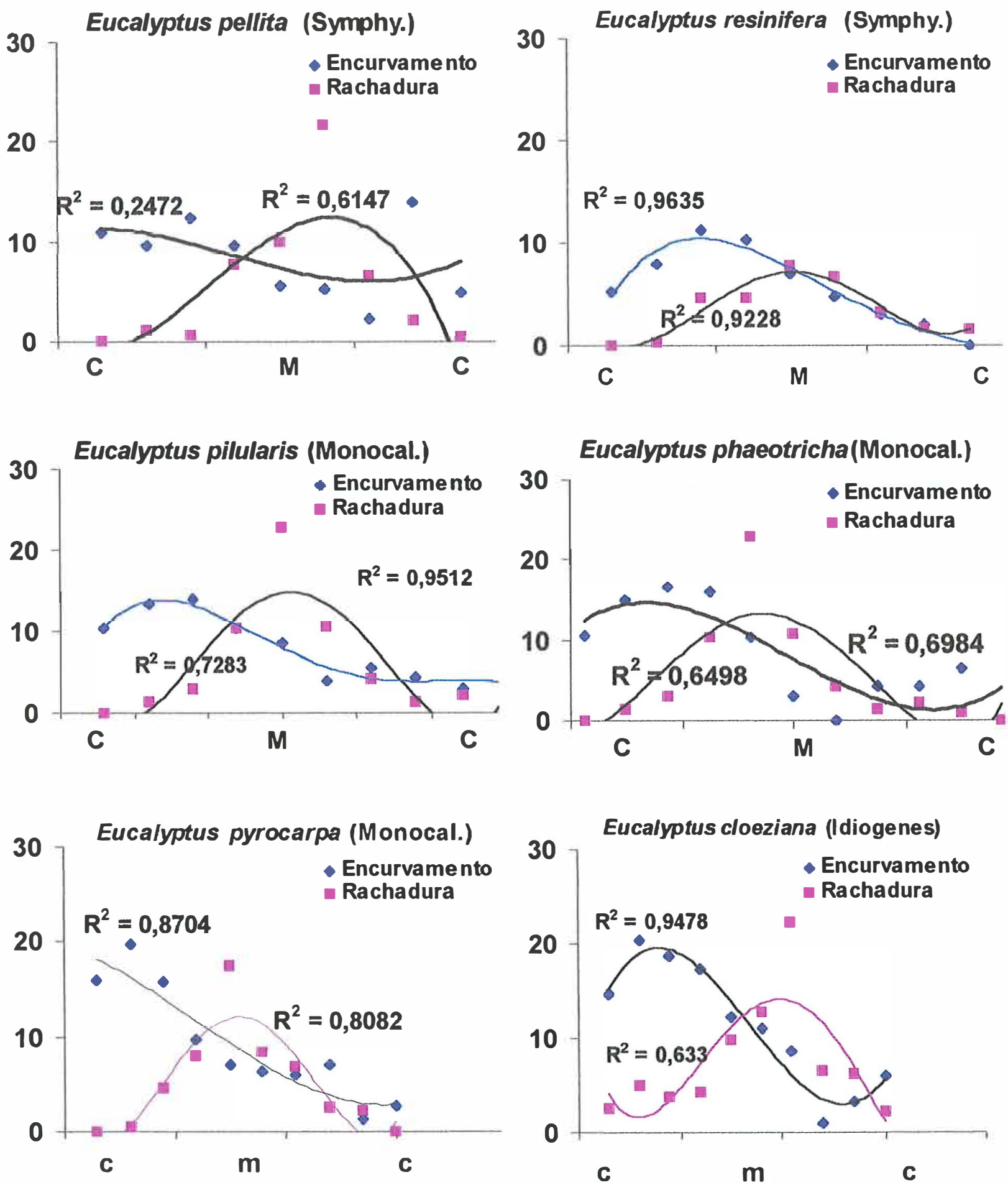

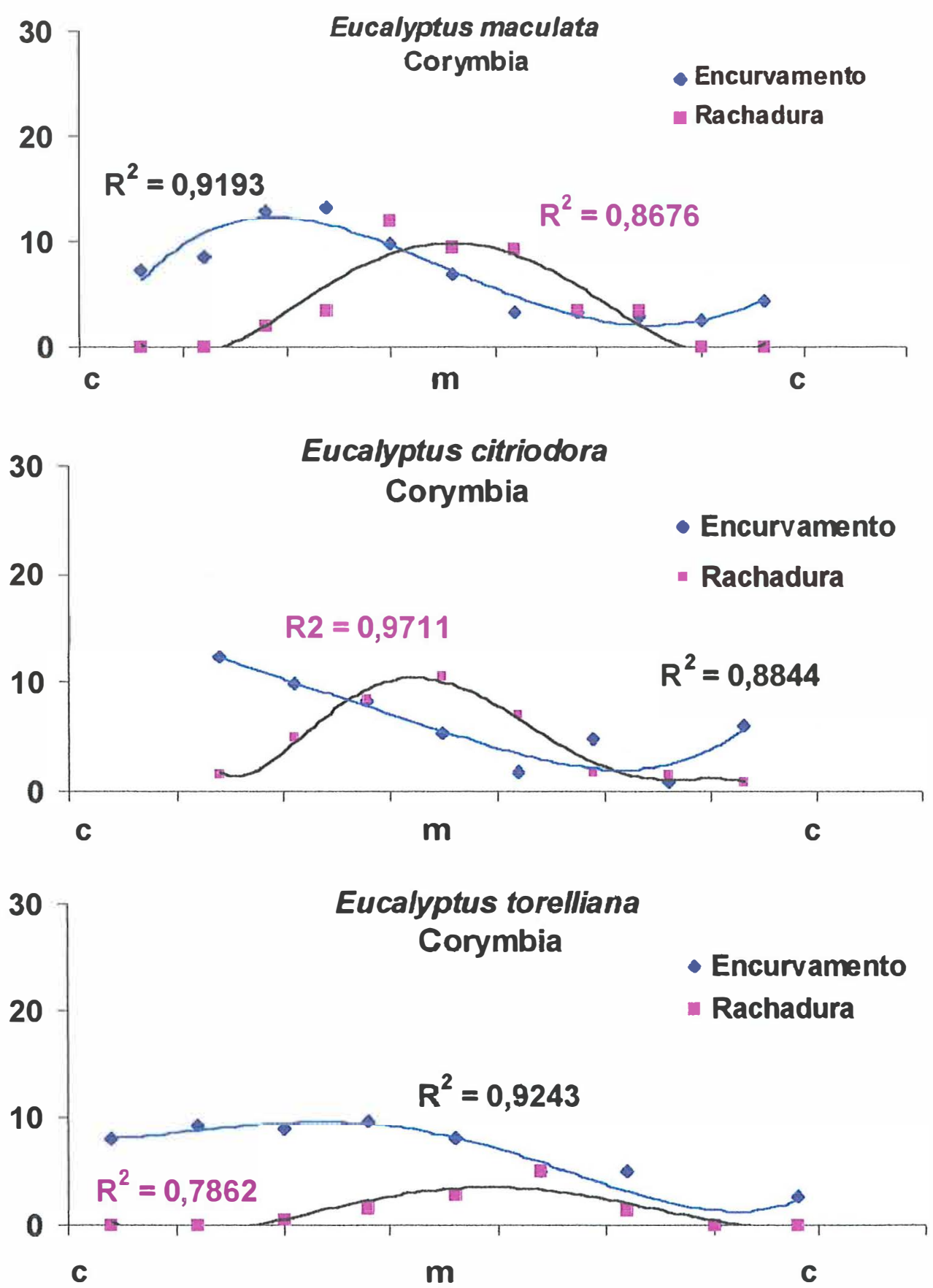

Figura 29 - Variação da rachadura e do encurvamento e do índice de rachaduras, ao longo do diâmetro da tora, nas 15 espécies de eucalipto, casca (c) a casca, passando pela medula (M). 
Este comportamento pode ser explicado pela metodologia de desdobro utilizada. Como o desdobro foi realizado numa serra de fita simples, de corte único, não foi possível liberar as tensões de crescimento de forma simétrica. Assim, à medida que as tábuas iam sendo cortadas, as tensões sofriam novas redistribuições com tendência à diminuição, pois parte das tensões residuais era absorvida pelo flexionamento do bloco remanescente da tora. isso resultou em tábuas de espessuras desuniformes, mais grossas no meio do seu comprimento e menos espessas nas suas extremidades. Consequentemente, à medida que os cortes avançavam ao longo do diâmetro, menores eram as intensidades dos empenamentos. Garcia (1995) recomenda que o corte único seja executado ao longo da curvatura da peça a ser serrada.

Quando se utilizam serras múltiplas, as tensões são liberadas simetricamente, obtendo-se com isto um bitolamento das tábuas e uma flecha mais ou menos constante em todas elas. Garcia (1995) salienta que os cortes duplos, quádruplos ou múltiplos como aqueles produzidos pela serra de quadro cheio exigem uma espessura mínima admissivel da prancha diametral, para resistir à rachadura longitudinal que tende a surgir ao longo da medula, exatamente como ocorreu nas tábuas diametrais do presente estudo. A tensão de tração na borda da prancha diametral é cerca de 2 vezes maior que aquela que existia na periferia da árvore.

Esse mesmo comportamento do encurvamento também foi encontrado por Del menezzi (1999), que observou que a ordem de retirada das tábuas influenciou a intensidade dos seus defeitos.

Observa-se a predominância de rachaduras na região próxima à medula da tora, para todas as espécie, indistintamente. A distribuição das rachaduras ao longo do diâmetro apresenta-se em forma de curva normal. Del Menezzi (1999), estudando o comportamento das rachaduras em Eucalyptus grandis e $E$. cloeziana, constatou também a tendência de diminuição da intensidade das 
rachaduras à medida que se afasta da medula. Segundo o mesmo autor, estas rachaduras são mais pronunciadas em indivíduos mais maduros.

Panshim \& Zeew (1970) também evidenciaram que as tábuas localizadas mais próximas à medula apresentavam maiores intensidades de rachaduras.

Os mesmos resultados para as rachaduras foram obtidos por Lopes (2000), que analisando o comportamento das rachaduras das extremidades de tábuas, na direção radial, observou que as tábuas mais próximas à medula apresentaram maiores indices de rachaduras.

As tábuas mais próximas da medula apresentaram maior intensidade de rachadura e menor encurvamento. Deste modo, à medida que se avança no sentido da casca, a intensidade da rachadura diminui e o encurvamento aumenta.

Garcia (1995) evidencia que em peças obtidas por um corte duplo seguido de um corte múltiplo, podem ser previsíveis as deformações máximas. $O$ encanoamento diminui e a flecha tende a aumentar com o aumento da distância da peça em relação à medula. Afirma ainda que, para uma dada posição, o encurvamento tende a diminuir com o aumento da largura da peça.

O encurvamento da tábua, de maior ou menor severidade, foi comum após o desdobro das toras das quinze espécies de Eucalyptus. Entretanto, uma secagem adequada contribuiu significativamente na minimização desse defeito.

Nas quinze espécies de Eucalyptus, todas as tábuas secas apresentaram uma forma quase retilinea, quase sem encurvamento. As imperfeições existentes poderiam ser corrigidas facilmente com um simples aplainamento ou com um leve esforço manual.

Crespo (2000) também concluiu que o encurvamento da madeira serrada seca é significativamente inferior, ao da madeira serrada no estado verde, demonstrando o efeito benéfico do processo de secagem. 
Del Menezzi (1999) estudando o E. grandis e E. cloeziana, também concluiu que os encurvamentos da madeira, foram reduzidos durante o processo de secagem.

O E. citriodora, E. resinifera e o E. toreliana com baixos indices de encurvamentos e rachaduras, e produtividade considerável, apresentam-se como espécies promissoras, com bons indicadores para a indústria moveleira e da construção civil. $O E$. citriodora já está sendo bem aceito na carpintaria. $O E$. resinifera e o $E$. toreliana, apresentam-se como espécies a serem mais investigadas. O E. toreliana também se destacou do $E$. citriodora e do $E$. maculata por não apresentar bolsas de kino na madeira. 


\subsection{Rendimento em madeira serrada (RMS)}

A crescente escassez de madeira de boa qualidade tem pressionado a indústria madeireira a trabalhar para melhorar o aproveitamento da matéria prima disponível. O custo da madeira colocada no pátio da serraria é um dos principais componentes dos custos totais e portanto, justifica o esforço para aumentar-se o rendimento em madeira serrada

$O$ desdobro em serra de fita única é o mais difundido entre as pequenas e médias indústrias na região sul do Brasil e o gênero Eucalyptus vem sendo cada vez mais utilizado como matéria prima para serraria em função da escassez crescente das madeiras tradicionais e principalmente pela facilidade e produtividade alcançado no cultivo do Eucalyptus.

O método de desdobro utilizado que alterna os cortes em faces opostas e paralelo ao eixo longitudinal da tora, também apresenta vantagens e desvantagens. A Figura 30 mostra o comportamento da tora de Eucalipto que se flexiona, contorce ou empena durante a retirada das tábuas, resultando em peças serradas com variações dimensionais na sua espessura. Por ser um processo de desdobro quase artesanal, o padrão de corte sofre pequena variação de uma tora para outra.

A medida que se realizam os cortes sucessivos tangenciais, o bloco remanescente se deforma por flexão, para adaptação às novas distribuições das tensões residuais, em função da liberação dos componentes das tensões de crescimento, Garcia (1995). Assim, o lado direito da tora ou bloco central da Figura 30 (a) que apresentava-se numa forma côncava passou a ser reta ou convexo, Figura 30 (b). Quando uma nova tábua é serrada por um novo corte retilíneo e paralelo ao eixo da peça remanescente, essa tábua tende a ficar convexa no lado direito e reta no lado esquerdo, Figura 30 (c). 
O gradiente residual ainda existente na tábua provoca um deslocamento de suas extremidades para a direita resultando em peças serradas com forma mais ou menos parecidas com aquela na Figura 30 (d).

Após o corte das ultimas tábuas, também de espessuras irregulares, a costaneira final, apresenta uma situação inversa daquela que tinha no início dos cortes, ou seja, a face esquerda da tora ou do bloco diametral que era convexa passou a ser côncava, Figura 30 (e).

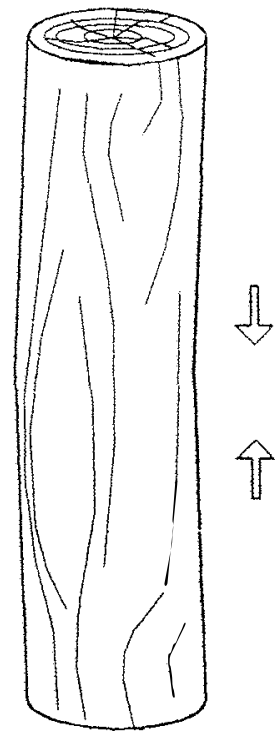

(a)

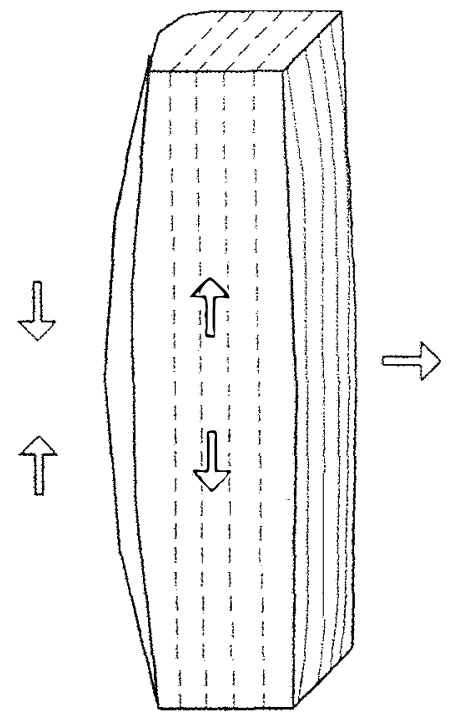

(b)

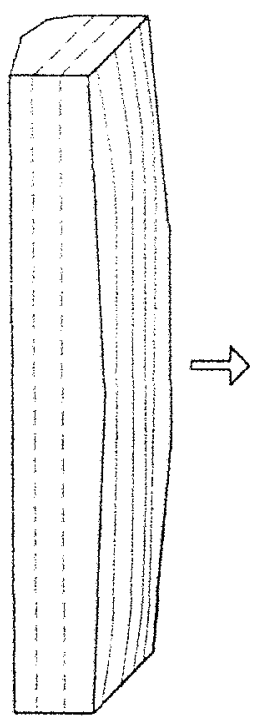

(c)

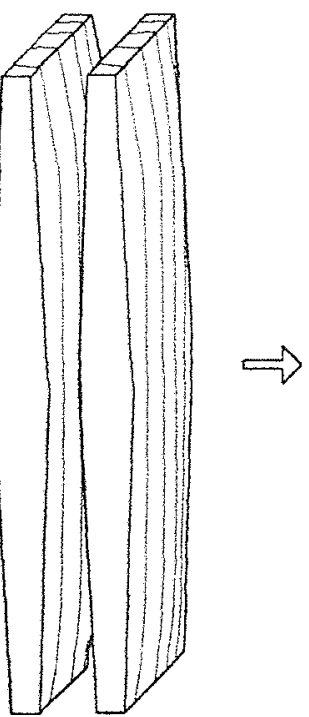

(d)

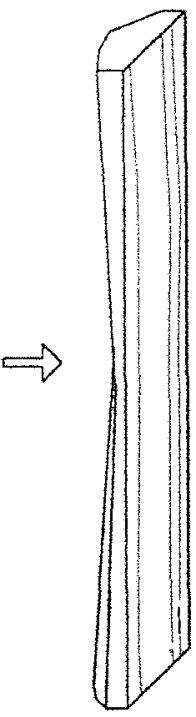

(e)

Figura 30 - Comportamento das peças serradas e da peça remanescente quando desdobrada em serra fita simples, segundo a técnica de cortes tangenciais sucessivos.

A média geral dos rendimentos em madeira desdobrada, obtidas das toras sem casca das quinze espécies de eucaliptos esteve ao redor de $62,77 \%$. Comparando-se estes rendimentos com aqueles obtidos na literatura, podemos considerar que os rendimentos conseguidos neste trabalho foram elevados

A tabela 32 apresenta os valores do rendimento em madeira serrada logo após o desdobro, das 15 espécies de eucalipto trabalhadas. 
Tabela 32. Rendimento em madeira serrada verde para toras sem casca.

\begin{tabular}{lcccccc}
\hline Espécie & Média (\%) & Mínimo (\%) & Máximo (\%) & s & CV (\%) & S $_{\mathbf{x}}$ \\
\hline E. resinifera & 70,87 & 64,00 & 75,33 & 4,65 & 6,56 & 1,90 \\
E. propinqua. & 67,90 & 59,20 & 73,81 & 5,17 & 7,61 & 2,11 \\
E. maculata & 66,75 & 62,56 & 72,75 & 4,42 & 6,62 & 1,80 \\
E. saligna & 66,53 & 58,77 & 76,78 & 6,82 & 10,25 & 2,78 \\
E. microcorys & 65,56 & 55,84 & 74,64 & 7,66 & 11,68 & 3,13 \\
E. pyrocarpa & 64,82 & 60,95 & 67,60 & 2,30 & 3,54 & 0,94 \\
E. cloeziana & 61,93 & 52,19 & 69,14 & 5,80 & 9,35 & 2,37 \\
E. pilularis & 61,80 & 54,48 & 69,13 & 6,41 & 9,24 & 2,61 \\
E. citriodora & 61,57 & 48,92 & 71,67 & 7,39 & 12,00 & 3,02 \\
E. tereticornis & 61,11 & 53,36 & 67,11 & 5,06 & 8,28 & 2,07 \\
E. pellita & 61,07 & 49,87 & 68,46 & 7,14 & 11,69 & 2,92 \\
E. urophylla & 60,94 & 44,93 & 71,02 & 10,16 & 16,68 & 4,15 \\
E. phaeotricha & 59,90 & 54,95 & 70,76 & 6,41 & 10,70 & 2,61 \\
E. toreliana & 56,44 & 51,31 & 62,24 & 3,99 & 7,06 & 1,62 \\
E. paniculata & 55,91 & 50,33 & 62,61 & 5,05 & 9,03 & 2,06 \\
\hline \multicolumn{4}{c}{ s= Desvio padrão } \\
\multicolumn{2}{c}{$\mathrm{CV}=$ Coeficiente de variação } & \multirow{2}{*}{$\mathrm{S}_{\mathbf{x}}^{-}=$Erro padrão da média }
\end{tabular}

As espécies que apresentaram os melhores rendimentos foram o $E$. resinifera $(70,87 \%)$, E. propinqua $(67,89 \%)$, E. maculata $(66,74 \%)$, e o $E$. saligna $(66,53 \%)$. Em contrapartida as espécies que apresentaram os piores rendimentos foram o E. paniculata $(55,91 \%)$, E. toreliana $(56,44 \%)$ e o E. phaeotricha, com $(59,90 \%)$.

O E. toreliana e o E. citriodora apresentaram em média os mais baixos indices de rachaduras e encurvamentos. Entretanto 0 baixo rendimento em madeira serrada destas espécies se atribui à forma do tronco que não era de muito boa conformação, com irregularidades e tortuosidades, resultando em maiores quantidades de residuos.

Embora seja difícil a uniformização do método de desdobro em todas as toras e espécies, o coeficiente de variação experimental médio de $10,0 \%$, demonstra pequena variabilidade do rendimento em madeira serrada, 
OE. paniculata, além de baixo rendimento no desdobro, apresentou uma significativa incidência de rachaduras. A grã apresenta-se muito espiralada, o que agrava a flexão da tora no momento do desdobro. Para sua utilização em serraria, será necessário submetê-la num programa de melhoramento. Esta espécie é mais indicada para utilização em bruto, como postes, dormentes e moirões. No arboreto de onde foram retiradas as árvores, havia algumas toras no solo com rachaduras de grande intensidade nos seus topos. Estas toras que seguramente apresentaram um baixo rendimento em madeira serrada, só poderiam ser indicadas para a produção de energia.

A Tabela 33 apresenta a análise da variância aplicada aos valores de rendimento em madeira serrada logo após o desdobro. Verifica-se diferenças significativas entre espécies e não significância entre as toras, para o rendimento em madeira serrada verde, base tora sem casca. Há evidências que, ao nivel de $5 \%$ de probabilidade, não existe interação entre os fatores espécie e tora.

Tabela 33. Análise da variância para o rendimento em madeira serrada.

\begin{tabular}{lcc}
\hline Causas de variação & GL & Pr $>F$ \\
\hline Espécie & 14 & 0,0051 \\
Toras & 1 & 0,8520 \\
Esp X Tor & 14 & 0,6753 \\
Resíduo & 29 & \\
\hline
\end{tabular}

$C V=10,0 \%$

A Tabela 34 apresenta o resultado do teste de comparação múltipla de Bonferroni, aplicado aos rendimentos em madeira serrada dos subgêneros. Verifica-se que, ao nível de $5 \%$ de probabilidade, não existem diferenças significativas entre os subgêneros.

Tabela 34. Rendimentos em madeira serrada dos subgêneros de Eucalyptus. 


\begin{tabular}{lcc}
\hline Causas de variação & Rendimento (\%) & Grupo (*) \\
\hline Symphyomyrtus & 63,74 & $\mathrm{a}$ \\
Idiogenes & 61,17 & $\mathrm{a}$ \\
Corymbia & 61,93 & $\mathrm{a}$ \\
Monocalyptus & 61,59 & $\mathrm{a}$ \\
\hline
\end{tabular}

(1) Médias com a mesma letra não são diferentes significativamente. $\mathrm{CV}=11,13 \%$

A Tabela 35 apresenta o Teste de comparação múltipla de Bonferroni para o rendimento em madeira serrada das quinze espécies de Eucalyptus, dentro dos seus subgêneros e também dentro do próprio gênero.

Tabela 35. Rendimentos em madeira serrada dentro de subgêneros e dentro do gênero Eucalyptus.

\begin{tabular}{|c|c|c|c|c|c|}
\hline \multirow[t]{2}{*}{ Subgênero } & \multirow[t]{2}{*}{ Gênero } & \multicolumn{2}{|c|}{$\begin{array}{c}\text { Rendimento } \\
(\%)\end{array}$} & \multirow{2}{*}{$\begin{array}{l}\text { Espécies } \\
\text { dentro de } \\
\text { subgênero }\end{array}$} & \multirow{2}{*}{$\begin{array}{c}\text { Espécies } \\
\text { dentro do } \\
\text { gênero }\end{array}$} \\
\hline & & (sc) & (cc) & & \\
\hline Symphyomyrtus & $\begin{array}{l}\text { E. resinifera } \\
\text { E. propinqua } \\
\text { E. saligna } \\
\text { E. microcorys } \\
\text { E. tereticornis } \\
\text { E. pellita } \\
\text { E. urophylla } \\
\text { E. paniculata }\end{array}$ & $\begin{array}{l}70,87 \\
67,89 \\
66,53 \\
65,56 \\
61,12 \\
61,07 \\
60,94 \\
55,91\end{array}$ & $\begin{array}{l}59,74 \\
59,03 \\
59,69 \\
55,53 \\
54,80 \\
50,10 \\
53,38 \\
44,77\end{array}$ & $\begin{array}{l}a \\
a b \\
a b \\
a b \\
a b \\
a b \\
a b \\
b\end{array}$ & $\begin{array}{l}a \\
a b \\
a b \\
a b \\
a b \\
a b \\
a b \\
b\end{array}$ \\
\hline Monocalyptus & $\begin{array}{l}\text { E. pyrocarpa } \\
\text { E. phaeotricha } \\
\text { E. pilularis }\end{array}$ & $\begin{array}{l}64,82 \\
59,90 \\
61,80\end{array}$ & $\begin{array}{l}55,60 \\
51,87 \\
53,09\end{array}$ & $\begin{array}{l}a \\
a \\
a\end{array}$ & $\begin{array}{l}a b \\
a b \\
a b\end{array}$ \\
\hline Corymbia & $\begin{array}{l}\text { E. maculata } \\
\text { E. citriodora } \\
\text { E. toreliana }\end{array}$ & $\begin{array}{l}66,75 \\
61,57 \\
56,44\end{array}$ & $\begin{array}{l}57,78 \\
51,87 \\
52,37\end{array}$ & $\begin{array}{c}a \\
a b \\
b\end{array}$ & $\begin{array}{l}a b \\
a b \\
a b\end{array}$ \\
\hline Idiogenes & E. cloeziana & 61,93 & 52,35 & & $a b$ \\
\hline
\end{tabular}

(*) Médias com a mesma letra não diferem estatisticamente entre si.

(sc) sem casca; (cc) com casca. $\quad \mathrm{CV}=10,0 \%$

Dentro do subgênero Symphyomyrtus verifica-se que existe diferença significativa entre $\circ E$. resinifera e $O E$. paniculata. $O$ restante das 
espécies formam um grupo intermediário que não diferem estatisticamente entre si.

Para as espécies que compreendem o subgênero Monocalyptus, não existem diferenças significativas entre si. Entretanto no subgênero Corymbia o $E$. toreliana diferiu significativamente do E. maculata.

Dentro do gênero, apenas o $E$. resinifera diferiu significativamente do E. paniculata. O restante das espécies formam um grupo intermediário que não diferem significativamente entre si.

De acordo com Ferreira ${ }^{7}$, o subgênero Monocalyptus é a madeira mais explorada comercialmente na Austrália. No Brasil as espécies que compreendem esse subgênero, apresentam problemas de adaptação, devido ao ataque de fungos na raiz e não produzem rebrota

Embora tenha havido uma leve tendência das toras superiores menos cônicas, apresentarem um maior rendimento, a diferença não foi estatisticamente significativa.

Freitas et al (1979), comenta que em desdobros experimentais realizados em serras de fita convencionais e em serras de quadro cheio vertical, têm-se obtido rendimentos da ordem de $50 \%$ a $70 \%$.

Tomazelli (1996), estudando a produção de serrados de espécies não tradicionais cultivadas em plantios de rápido crescimento, obteve os seguintes rendimentos base tora com casca: Alamo $61 \%$, Cunninghamia 60 \%, Grevillea $54 \%$, Uva do Japão $52 \%$, Boleira e Casuarina $45 \%$, Pecã 44 $\%$ e Gmelina $38 \%$. Estes rendimentos superam os obtidos no processamento dos Pinus, tradicionalmente utilizados em serrarias da região sul.

A figura 31 apresenta uma melhor visualização dos rendimentos em madeira serrada, base tora com casca e também sem casca, das quinze espécies de Eucaliptos.

\footnotetext{
${ }^{7}$ FERREIRA, M. Comunicação pessoal, 2000.
} 
MIV Corymbia $\quad$ ||||||||||||| Idiógenes

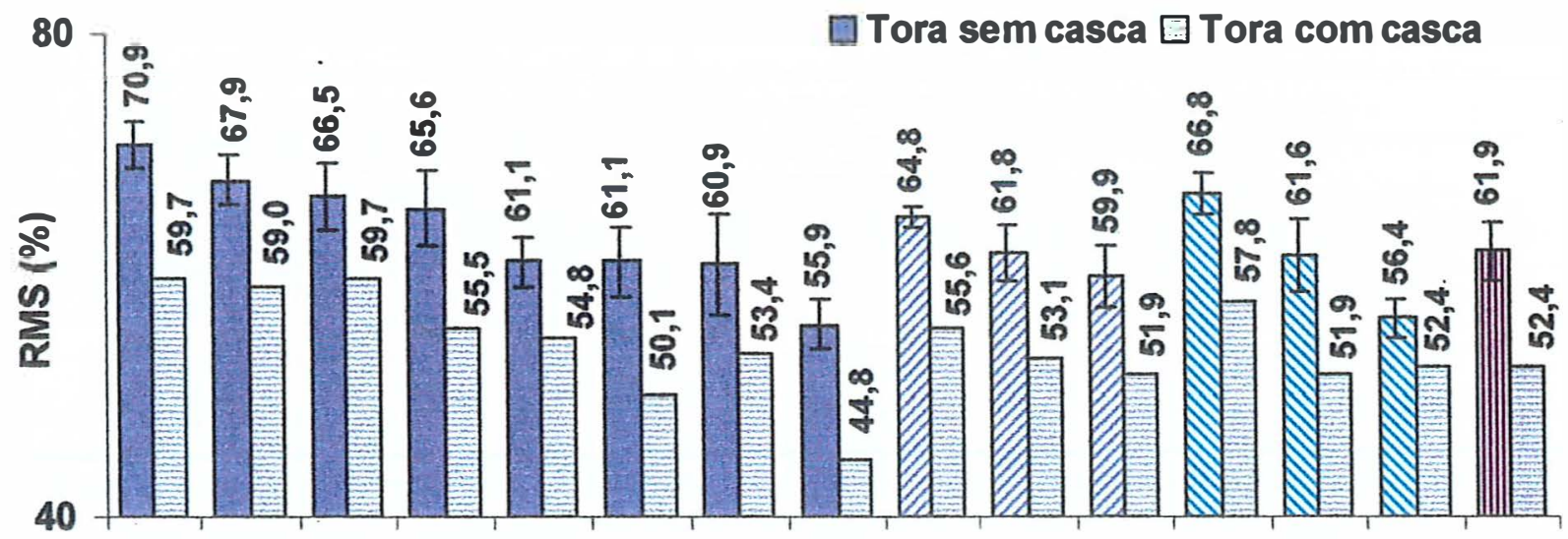

res pro sal mic ter pel uro pan pyr pil pha mac cit tor clo

Figura 31 - Rendimentos da madeira desdobrada, considerando as médias com e sem casca.

Acosta (1996), estudando o rendimento em madeira serrada de $E$. grandis, afirma que na base de diâmetros variando entre $25-40 \mathrm{~cm}$, os rendimentos em madeira serrada varia de 57 a $60 \%$.

Miranda (1997), trabalhando com toras de diâmetro médio de 20,31 $\mathrm{cm}$, obteve um rendimento médio de $41 \%$. Neste trabalho o autor não faz menção se o rendimento foi calculado com base tora com ou sem casca.

Silva (1991) observou rendimentos em madeira serrada para os produtos tábuas e pranchas variando de $41,39 \%$ a $51,76 \%$, base tora com casca, para um intervalo de diâmetro de 27,5 à $50 \mathrm{~cm}$.

Segundo o mesmo autor, os baixos níveis de rendimentos podem ser atribuído aos equipamentos utilizados como excessiva espessura de corte que causa considerável perda de material lenhoso. As tensões de crescimento provocam rachaduras e variaçōes na espessura das peças desdobradas, afetando, o rendimento, uma vez que a largura e a espessura das tábuas foram tomadas na ponta mais estreita e mais fina respectivamente. 


\subsection{Associação entre variáveis}

O rendimento em madeira serrada é influenciado por vários fatores como o diâmetro, forma e conicidade da tora, rachaduras de extremidades das tábuas, espessura e precisão de corte da serra de fita (Sayagués, 1999; CORFO/INFOR, 1989). Neste capítulo serão apresentados e discutidos as correlações entre as variáveis estudadas para verificar-se o grau de influência que cada uma delas exerce nas demais. Dessa forma pretende-se iniciar um trabalho de redução do número das variáveis tecnológicas necessárias para caracterizar-se uma espécie.

Por se trabalhar com várias espécies, procurou-se selecionar indivíduos, que apresentassem a maior semelhança possivel. Entretanto foi impossivel obter-se uma rigorosa uniformidade de padrōes como diâmetro, idade, forma e manejo dos diferentes povoamentos. Assim, diferentes padrōes de árvores e espécies, que resultam numa maior variabilidade genética, podem ter sido considerados na análise de uma mesma característica.

A associação entre as variáveis foi determinada através do coeficiente de correlação não paramétrico de Spearman, também conhecido como correlação linear de postos, calculado a partir dos valores originais obtidos.

Paula Neto (1999) cita que o cálculo do coeficiente de correlação com base nos postos, pode ser utilizado como alternativa ao cálculo com base nos valores de duas variáveis quantitativas por uma questão de facilidade, desde que não se tenha muita exigência quanto ao rigor. Muitas vezes um alto valor do Coeficiente de Correlação, embora estatisticamente significativo, pode não implicar em qualquer relação de causa e efeito, mas simplesmente à tendência que as variáveis apresentam quanto a sua variação conjunta. 
Como resultado principal, na análise de correlação pelo método de Spearman, obtém-se um coeficiente numérico que varia entre $(-1)$ e $(+1)$. A obtenção de um coeficiente de correlação igual, em valor absoluto, a 1, indica que uma variável pode ser escrita exatamente como uma função linear da outra. O sinal positivo ou negativo, do coeficiente de correlação somente indica se a relação entre as variáveis é direta ou inversa. Um coeficiente de correlação igual a zero, assumindo-se distribuição normal, indica que as variáveis são independentes, ou seja, não há correlação entre elas, Alves (1994).

O coeficiente de correlação de Spearman (CCS) está associado ao nivel de significância ( $\rho$ ) ou com uma probabilidade de erro para a aceitação ou rejeição da hipótese. Em geral, admite-se um nível de significância de $5 \%$.

Sounis (1979), propõem a tabela de Rugg para comparar as classes e as denominações do CCS, mostrados na Tabela 36, para servirem como referência na classificação desse coeficiente.

Tabela 36. Classificação dos Coeficientes de Correlação de Spearman (CCS).

\begin{tabular}{cc}
\hline Intervalo de CCS & Classificação \\
\hline $\operatorname{CCS}<0,15$ & Desprezível \\
$0,15<\operatorname{CSS}<0,29$ & Baixo \\
$0,30<\operatorname{CS}<0,49$ & Apreciável (Alto) \\
$\operatorname{CCS}>0,50$ & Acentuado (Muito alto) \\
\hline
\end{tabular}

Os parâmetros da correlação de Spearman calculado para as associações do universo de todas as 15 espécies, encontram-se na Tabela 37. 
Tabela 37. Parâmetros das correlações de Spearman.

\begin{tabular}{lccc}
\hline Associação & CCS & Classificação & Pr. > F \\
\hline RMS e diâmetro & 0,0483 & Desprezível & $0,6511(\mathrm{~ns})$ \\
RMS e IR & $-0,3624$ & Apreciável & $0,0004\left(^{*}\right)$ \\
RMS e conicidade & 0,0324 & Desprezível & $0,7617(\mathrm{~ns})$ \\
RMS e encurvamento & 0,2197 & Baixo & $0,037\left(^{*}\right)$ \\
Encurvamento e IR & 0,4814 & Apreciável & $0,0001\left(^{*}\right)$ \\
IR e diâmetro & $-0,0185$ & Desprezível & $0,8625(\mathrm{~ns})$ \\
Encurvamento e diâmetro & $-0,3113$ & Apreciável & $0,0028\left(^{*}\right)$ \\
\hline (*) Significativo a 5\%. $^{*}$ (ns) Não significativo &
\end{tabular}

\subsubsection{Rendimento em madeira serrada (RMS) e diâmetro}

O baixo valor da $\operatorname{CCS}(0,0483)$ indica que a correlação entre o RMS e os diâmetros das toras é desprezivel. Esse fato também pode ser confirmado na figura 32 onde se observa que o diâmetro responde com menos de $1 \%$ da variável do rendimento.

Há evidência, ao nível de $5 \%$ de significância, de que o rendimento em madeira desdobrada não está associado ao diâmetro médio das tora. $\mathrm{O}$ rendimento em madeira serrada independe do diâmetro médio das toras, pois a probabilidade de ocorrer uma a ssociação devido ao acaso é de 65,11 $\%$. A Figura 33 mostra que em termos de média de espécies o diâmetro explica somente $0,2 \%$ da variação do rendimento.

$\mathrm{Na}$ figura 34 além da baixa significância da correlação, observa-se nas toras superiores um comportamento aleatório para os rendimentos, com tendência a diminuir o rendimento quando ocorre um acréscimo do diâmetro.

$\mathrm{Na}$ tora $\mathrm{B}$, subsequente à da base a tendência de decréscimo de rendimento em madeira serrada em função do diâmetro se deve à variação da forma das toras e á variação encontrada da espessura das costaneiras. $\mathrm{Na}$ análise da associação dentro de tora, observou-se um melhor coeficiente de determinação na tora $A$, da base. 


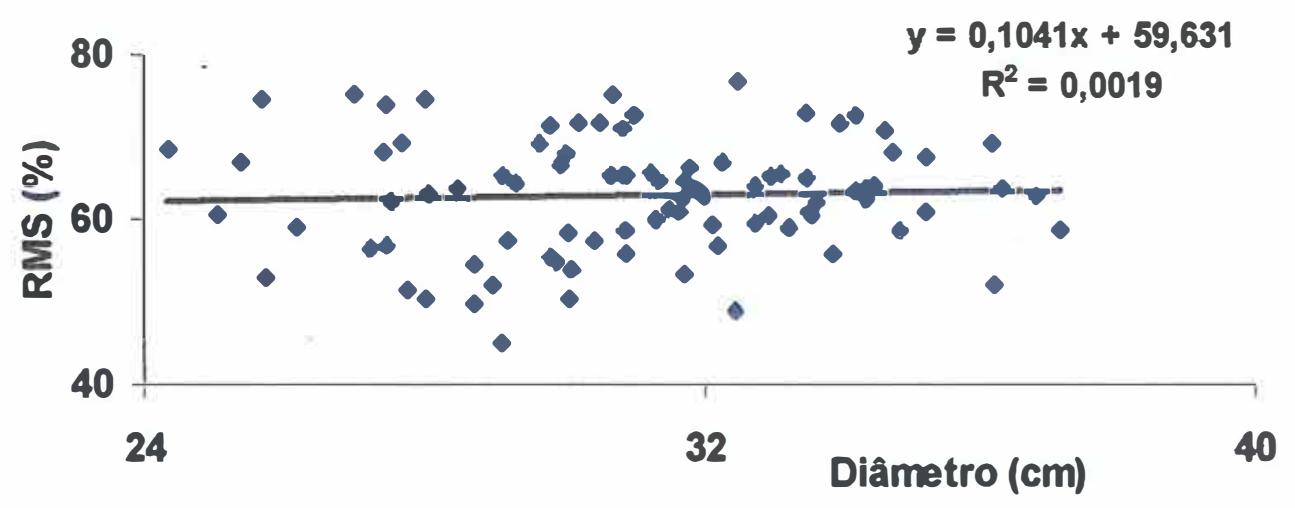

Figura 32 - Rendimento em madeira serrada verde (RMS) base tora sem casca, para o conjunto das 90 toras de eucaliptos.

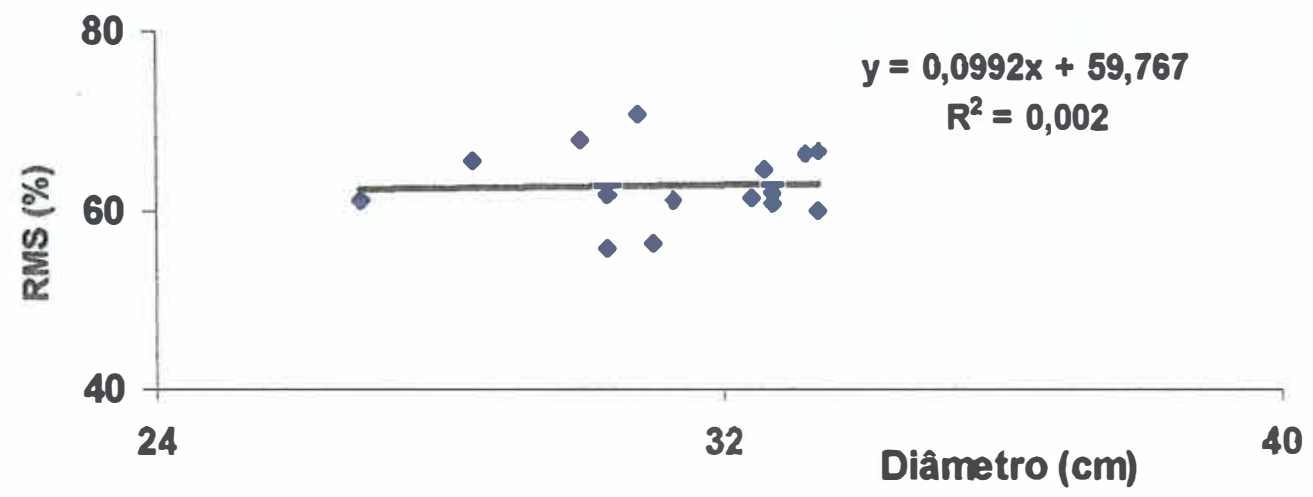

Figura 33 - Rendimento em madeira serrada (RMS) base tora sem casca, para o conjunto, das quinze espécies de Eucalyptus.

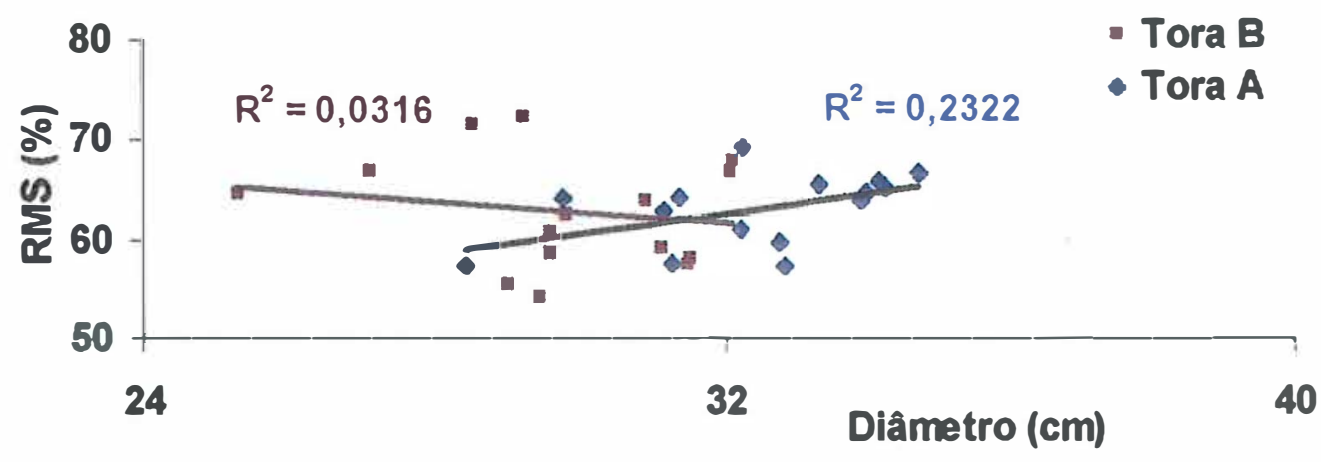

Figura 34 - Rendimento em madeira serrada (RMS) dentro de toras. 
Tabela 38. Niveis de significância, do rendimento em madeira serrada em função dos diâmetros, dentro de espécies.

\begin{tabular}{lrlrll}
\hline \multicolumn{1}{c}{ Espécie } & $\mathrm{Pr}>\mathrm{F}$ & \multicolumn{1}{c}{ Espécie } & $\mathrm{Pr}>\mathrm{F}$ & \multicolumn{1}{c}{ Espécie } & $\mathrm{Pr}>\mathrm{F}$ \\
\hline E. microcorys & 0,787 & E. paniculata & 0,036 & E. pellita & 0,156 \\
E. propinqua & 0,042 & E. resinifera & 0,468 & E. saligna & 0,787 \\
E. tereticornis & 0,871 & E. urophylla & 0,957 & E. cloeziana & 0,005 \\
E. pilularis & 0,872 & E. phaeotricha & 0,111 & E. pyrocarpa & 0,329 \\
E. citriodora & 0,787 & E. maculata & 0,156 & E. toreliana & 0,041 \\
\hline
\end{tabular}

Pode-se considerar correlação significativa apenas no E. cloeziana, E. paniculata, E. phaeotricha, E. propinqua e E. toreliana. As demais espécies os rendimentos apresentaram baixa dependência de rendimento em relação aos diâmetros.

A Figura 35 mostra que a correlação entre o rendimento de madeira serrada e o diâmetro, não apresentou o mesmo padrão em todas as espécies. Observa-se nos três subgêneros, espécies com correlações positivas e negativas. Na prática do desdobro dos eucaliptos nem sempre exista uma correlação positiva, entre essas variáveis. No presente estudo os resultados podem ficar mascarados em função das diferentes formas das toras, diferentes intensidades de rachaduras nas extremidades das tábuas e falhas operacionais que podem redundar na imprecisão de cortes. Não é raro encontrar espécies que apresentem grande variação no rendimento em madeira serrada, mesmo apresentando baixa variação de diâmetro.

Miranda (1997) evidenciaram estatisticamente que o rendimento em madeira desdobrada é dependente do diâmetro da ponta mais fina da tora, para o espaçamento de plantio de $3 \times 4 \mathrm{~m}$. Nos espaçamentos $3 \times 3$ e $4 \times 4$ não houve significância estatística.

Silva (1991), também verificou que os diâmetros das toras não influenciaram no rendimento de madeira serrada. 

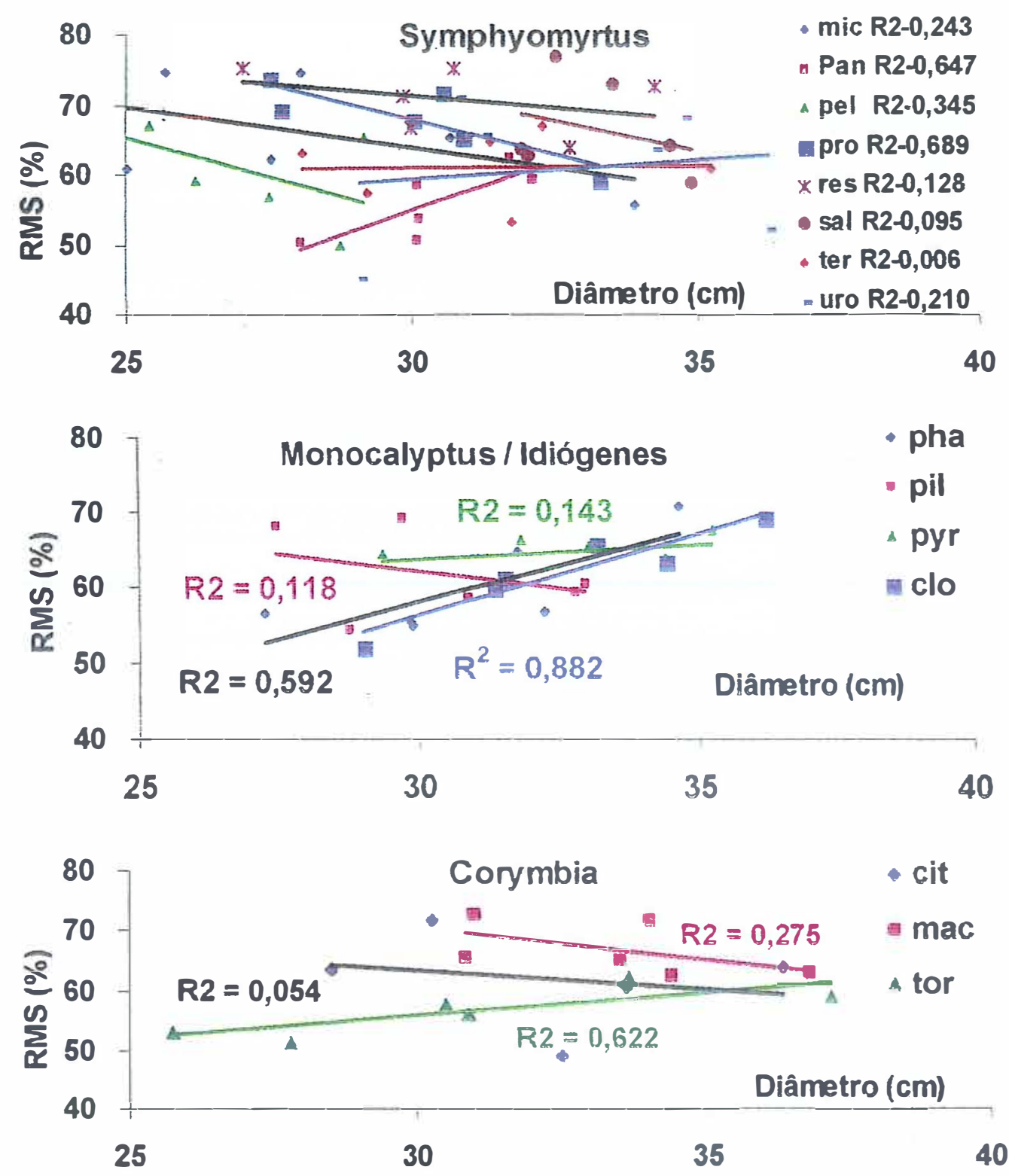

Figura 35 - Rendimento em madeira serrada dos subgêneros Symphyomyrtus, Monocalyptus e Corymbia, em função do diâmetro da tora. 


\subsubsection{Rendimento e rachadura (IR)}

O rendimento em madeira serrada está fortemente associado às rachaduras de extremidade de tábuas (Tabela 37). Embora haja uma grande variação em torno da média (Figura 36), a tendência foi a de diminuição do rendimento em madeira serrada com o aumento das rachaduras em praticamente nas 15 espécies de Eucalyptus.

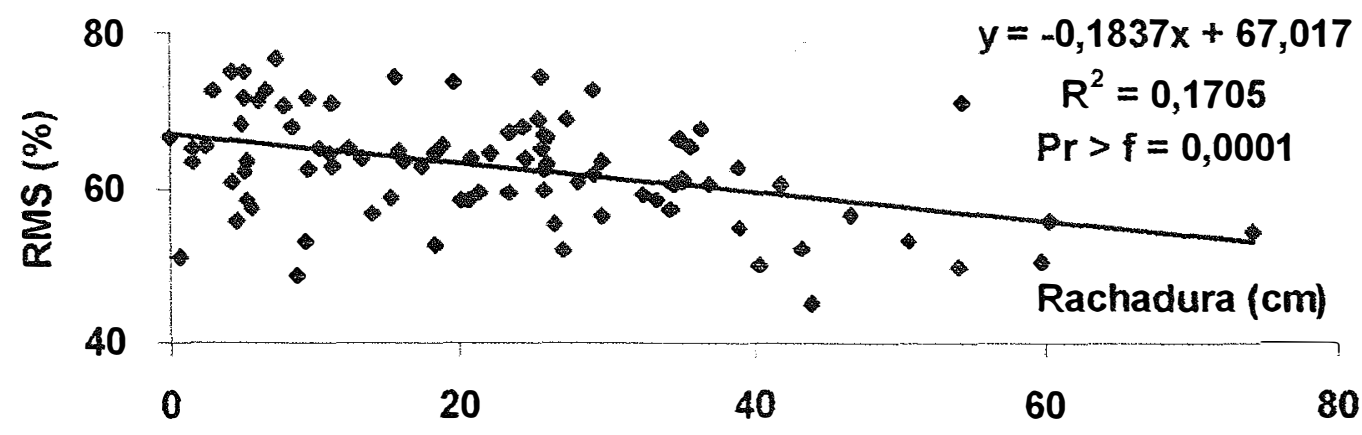

Figura 36 - Rendimento em madeira serrada (RMS), em função das rachaduras de extremidade de tábuas (IR), para o universo de 90 toras.

Tabela 39. Niveis de significância entre o rendimento em madeira serrada e o indice de rachaduras de extremidade de tábuas dentro de espécies.

\begin{tabular}{lclcll}
\hline \multicolumn{1}{c}{ Espécie } & $\mathrm{Pr}>\mathrm{F}$ & \multicolumn{1}{c}{ Espécie } & $\mathrm{Pr}>\mathrm{F}$ & Espécie & $\mathrm{Pr}>\mathrm{F}$ \\
\hline E. microcorys & 0,019 & E. paniculata & 0,266 & E. pellita & 0,072 \\
E. propinqua & 0,156 & E. resinifera & 0,019 & E. saligna & 0,396 \\
E. tereticornis & 0,110 & E. urophylla & 0,872 & E. cloeziana & 0,072 \\
E. pilularis & 0,329 & E. phaeotricha & 0,208 & E. pyrocarpa & 0,787 \\
E. citriodora & 0,872 & E. maculata & 0,0001 & E. toreliana & 0,704 \\
\hline
\end{tabular}

A Figura 37 mostram que as espécies de E. citriodora (Corymbia) e $E$. pyrocarpa (Monocalyptus), apresentaram correlação positiva entre o rendimento em madeira serrada e o índice de rachadura de extremidade das tábuas. Entretanto, essas correlaçōes anormais, só ocorreram em espécies que apresentaram baixos indices de rachaduras, não foram significativas. 

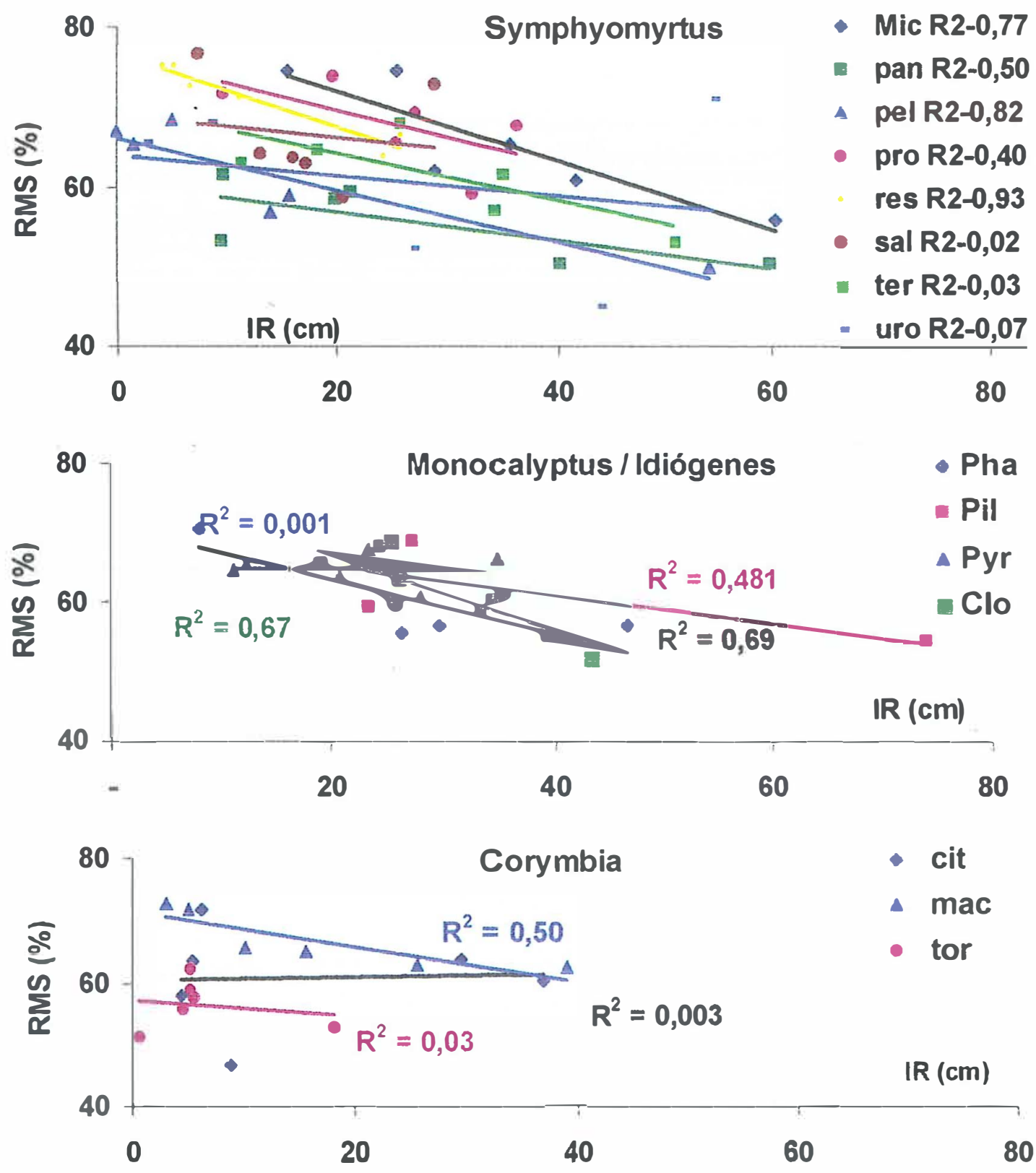

Figura 37 - Rendimento em madeira serrada dos subgêneros Symphyomyrtus, Monocalyptus e Corymbia, em função das rachaduras de extremidade de tábua.

Crespo (2000) verificou que um aumento no comprimento da rachadura de extremidade de tábua segue uma redução proporcional no rendimento em madeira serrada. Conclui ainda que o rendimento em madeira serrada verde não depende do índice de rachadura de extremidade da tora. 


\subsubsection{Rendimento em madeira serrada (RMS) e conicidade}

O rendimento em madeira serrada mostrou ser independente da conicidade das toras, no conjunto de todas as quinze espécies de eucalipto, como apresentado na Tabela 37 e Figura 38.

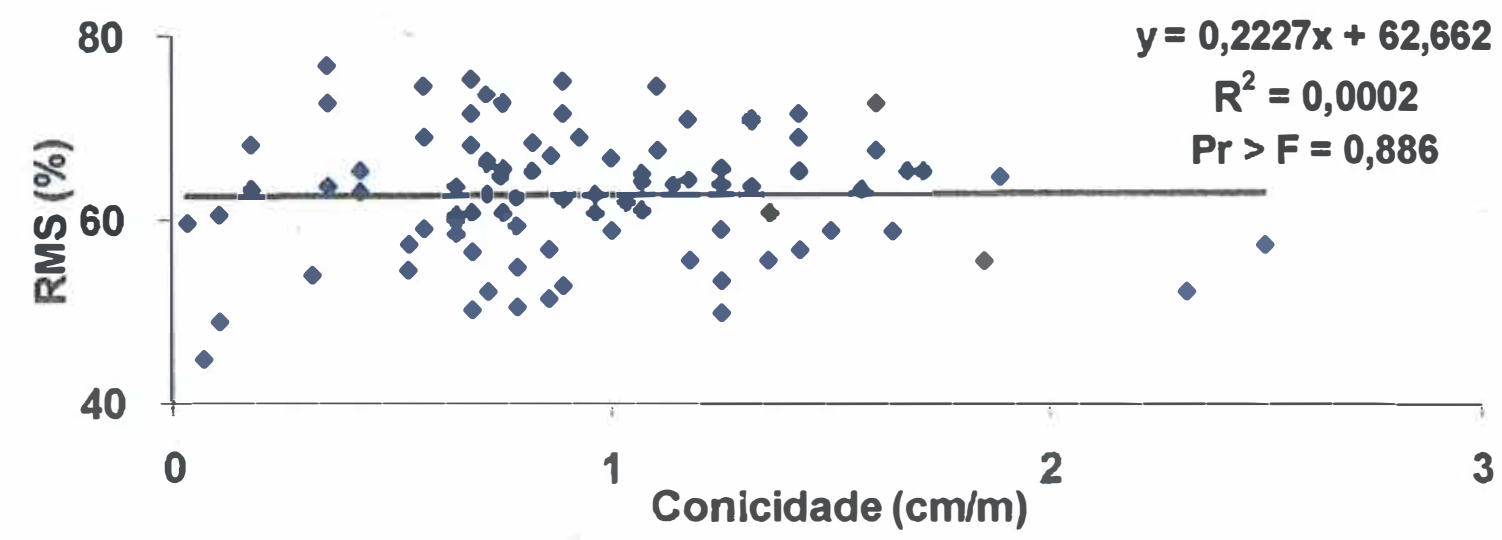

Figura 38 - Rendimento em madeira serrada em função da conicidade para o conjunto de 90 toras de eucaliptos.

A figura 39 mostra que as relações entre o rendimento em madeira serrada e a conicidade da tora não são significativas dentro da tora.

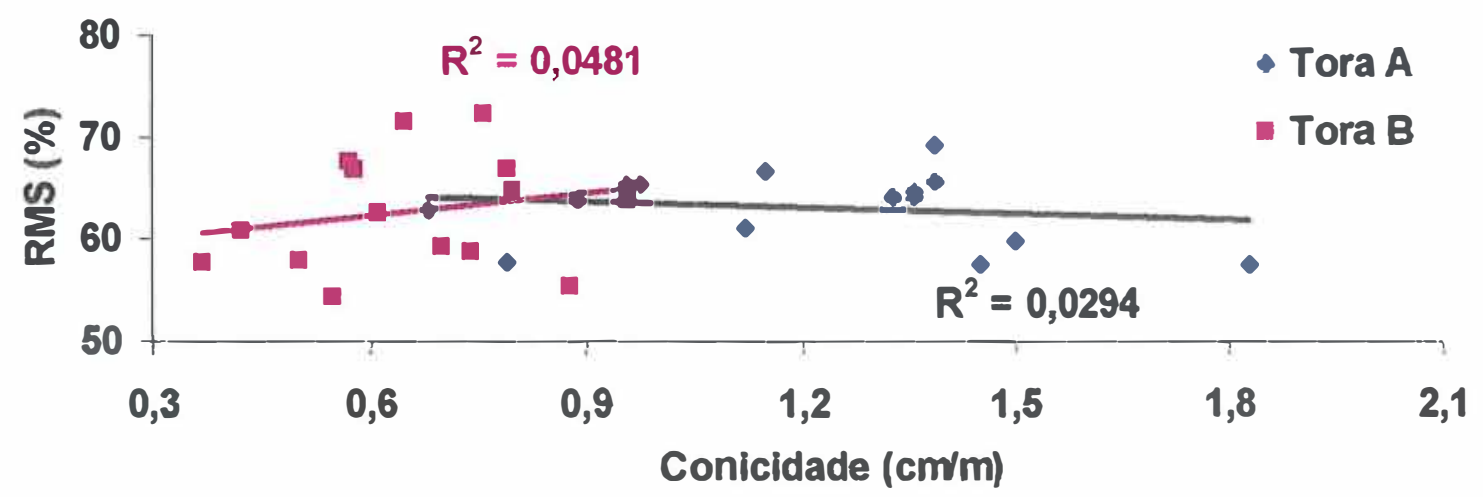

Figura 39 - Rendimento em madeira serrada em função da conicidade e posição da tora na árvore.

Miranda (1997), obteve resultados semelhantes ou seja, os rendimentos foram independentes da conicidade. 
Tabela 40. Nível de significância entre rendimento e a conicidades das toras nas quinze espécies de eucalipto.

\begin{tabular}{|c|c|c|}
\hline Espécie - Pr $>F$ & Espécie - Pr > F & Espécie - Pr > F \\
\hline E. microcorys - 0,329 & E. paniculata $-0,518$ & E. pellita - 0,544 \\
\hline E. propinqua $-0,110$ & E. resinifera $-0,544$ & E. saligna $-0,050$ \\
\hline E. tereticornis $-0,872$ & E. urophylla - 0,864 & E. cloeziana - 0,156 \\
\hline E. pilularis $-0,787$ & E. phaeotricha - 0,623 & E. pyrocarpa $-0,396$ \\
\hline E. citriodora $-0,111$ & E. maculata $-0,957$ & E. toreliana $-0,321$ \\
\hline
\end{tabular}

A Tabela e a Figura 40 mostram que, também dentro de espécies, a influência da conicidade no rendimento em madeira serrada foi suplantado por uma outra variável não controlada. Somente no E. saligna pôde-se observar uma correlação significativa entre rendimento e conicidade da tora.

Nos subgêneros Monocalyptus e também no E. cloeziana, observa-se um anormal aumento do rendimento em madeira serrada com o aumento da conicidade da tora. Isso significa que nesses subgêneros deve existir alguma variável, ainda não isolada, que é ligada á conicidade e extremamente benéfica ao rendimento em madeira serrada.

Crespo (2000), verificou que ocorre uma redução no rendimento em madeira serrada, proporcionalmente ao aumento da conicidade da tora. Verificou também, que a conicidade é uma das caracteristicas da tora que mais afeta o rendimento em serraria. 

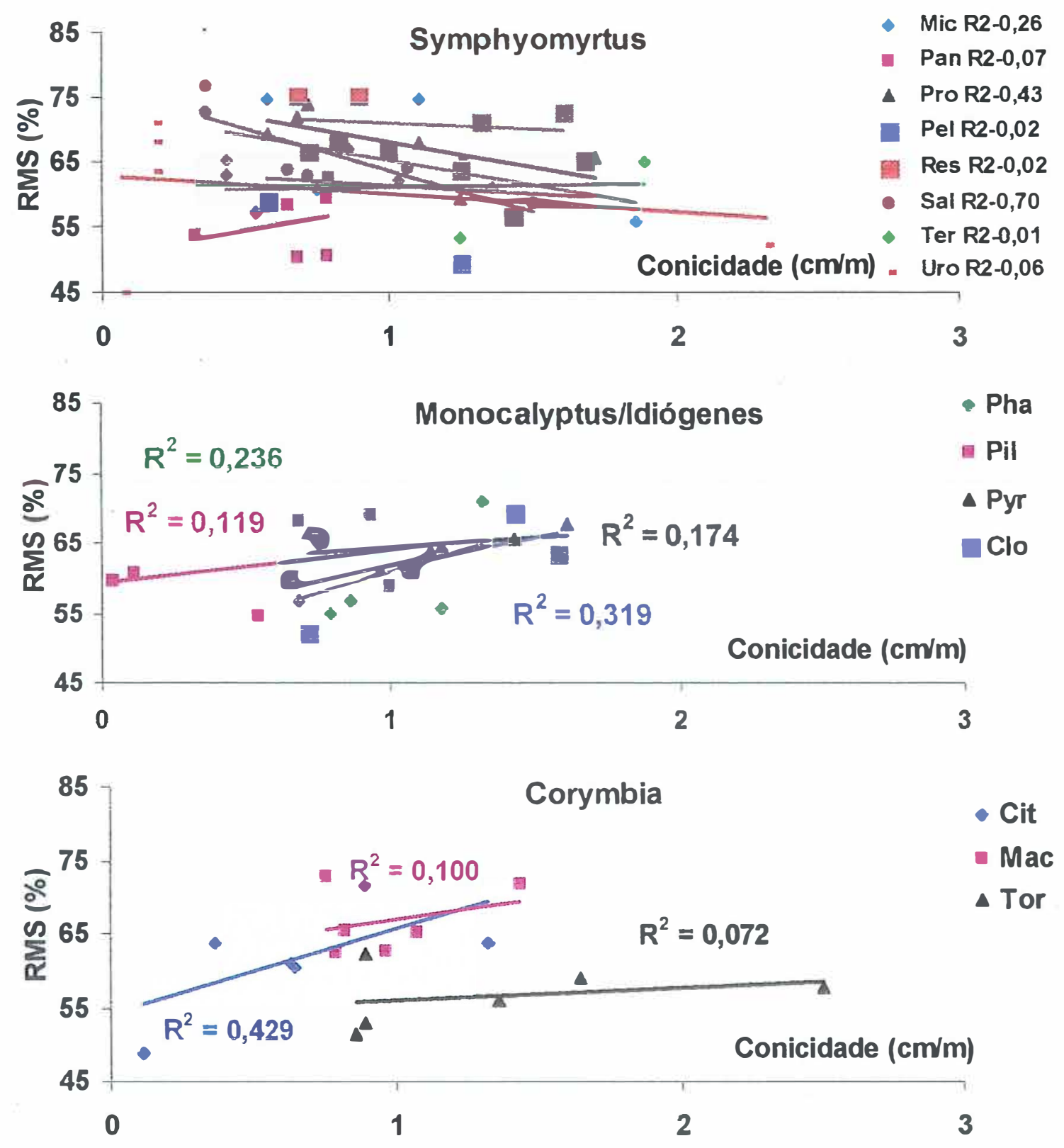

Figura 40 - Relação entre rendimento em madeira serrada (RMS) e conicidade, dentro de espécies e de subgênero. 


\subsubsection{Rendimento e encurvamento}

Conforme mostra a Tabela 37, existe uma relação inversamente proporcional entre o rendimento em madeira serrada e o encurvamento de tábua. Isso acontece porque o encurvamento é uma das manifestações das tensões de crescimento e a tensão de crescimento é prejudicial ao rendimento. Entretanto, é importante observar na figura 41 , que o encurvamento responde por apenas $6,5 \%$ da variação de rendimento em madeira serrada.

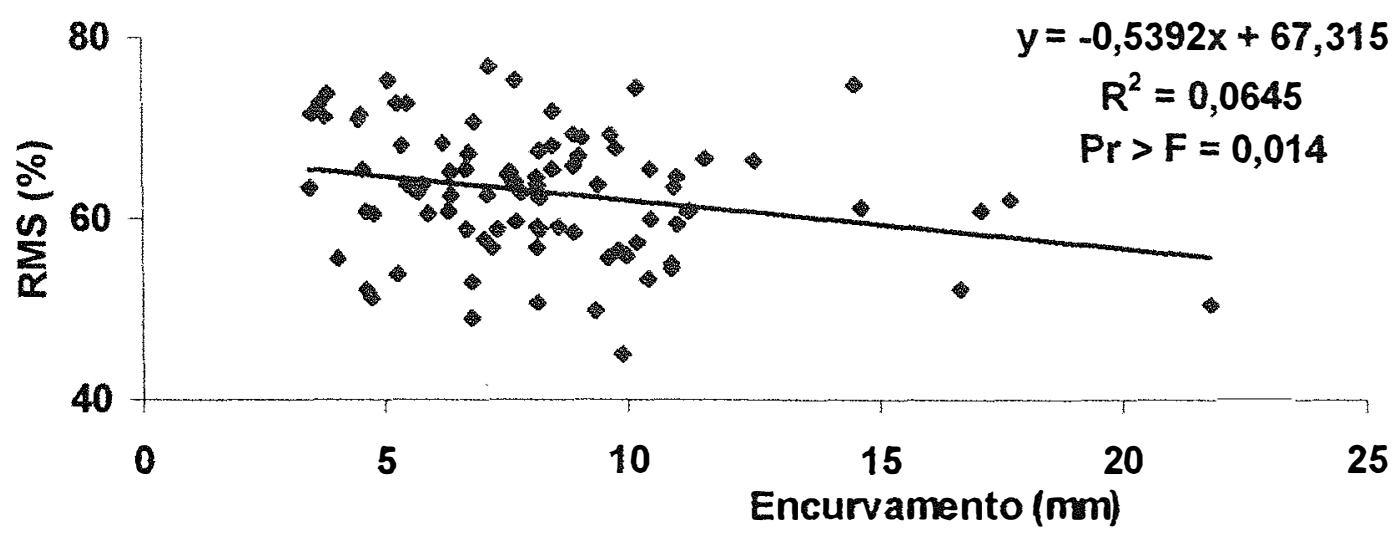

Figura 41 - Rendimento de madeira em função do encurvamento da tábua para o conjunto das 90 toras de eucalipto.

A Tabela 41 mostra que apenas no E. phaeotricha e no E. tereticornis existem correlações significativas entre o rendimento em madeira serrada e o encurvamento

Tabela 41. Niveis de significância das relações entre o rendimento em madeira serrada e o encurvamento das tábuas dentro de espécies de eucalipto.

\begin{tabular}{lclrlr}
\hline \multicolumn{1}{c}{ Espécie } & $\mathrm{Pr}>\mathrm{F}$ & \multicolumn{1}{c}{ Espécie } & $\mathrm{Pr}>\mathrm{F}$ & \multicolumn{1}{c}{ Espécie } & $\mathrm{Pr}>\mathrm{F}$ \\
\hline E. microcorys & 0,704 & E. paniculata & 0,544 & E. pellita & 0,208 \\
E. propinqua & 0,787 & E. resinifera & 0,787 & E. saligna & 0,623 \\
E. tereticornis & 0,156 & E. urophylla & 0,468 & E. cloeziana & 0,072 \\
E. pilularis & 0,872 & E. phaeotricha & 0,008 & E. pyrocarpa & 0,469 \\
E. citriodora & 0,266 & E. maculata & 0,396 & E. toreliana & 0,041 \\
\hline
\end{tabular}


A Figura 42 apresenta a dispersão dos dados em relação à reta que transforma o encurvamento em rendimento de madeira serrada por espécie de Eucalyptus; classificadas por subgênero. Apenas o E. toreliana apresentou um comportamento inverso, à todas as demais espécies. Isso significa que, para essa espécie, o encurvamento está associada a alguma característica muito influente no seu rendimento em madeira serrada.
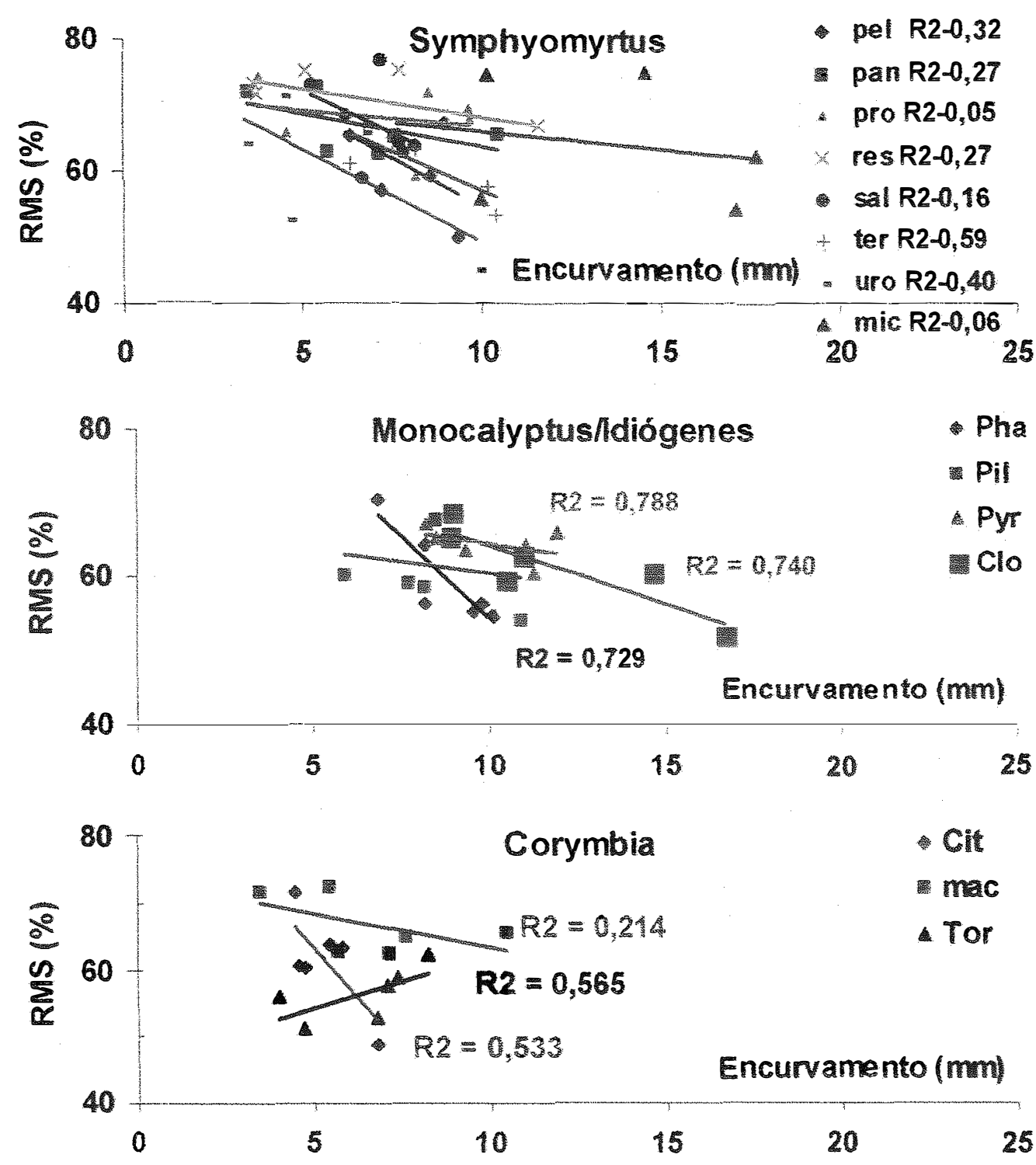

Figura 42 - Rendimento em madeira serrada (RMS), em função do encurvamento da tábua. 


\subsubsection{Encurvamento $e$ indice de rachadura (IR)}

A Tabela 37 e a Figura 43 mostra que existe uma forte correlação entre o encurvamento e o índice de rachadura de extremidade de tábuas. Entretanto, a dispersão em torno da média é muito grande e crescente com o aumento do indice de rachaduras. Para o conjunto das 90 toras das 15 espécies de eucalipto, o encurvamento responde por apenas $18,6 \%$ da variação do índice de rachadura.

Tendo em vista que essas duas variáveis são advindas das tensões de crescimento, pode-se afirmar que a correlação entre elas foi, inesperadamente baixa.

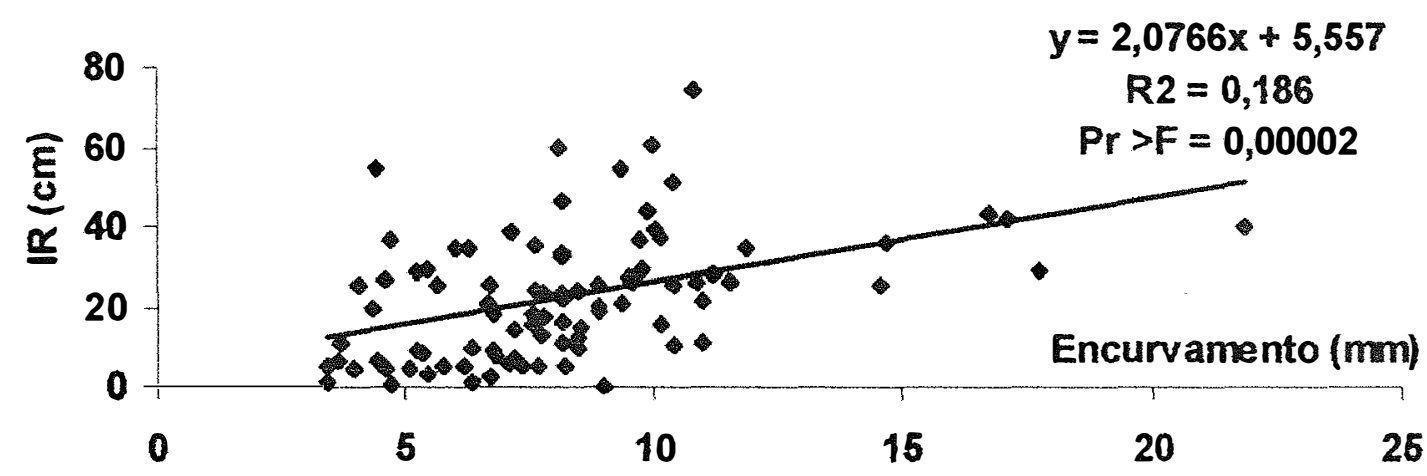

Figura 43 - Relação entre rachaduras de extremidade de tábuas e encurvamento para o universo de 90 toras de Eucalyptus.

A Tabela 42 mostra que apenas no E. cloeziana foi encontrado uma correlação significativa entre $o$ índice de rachadura de extremidade de tábuas e o encurvamento. Nessa espécie, os encurvamentos responderam por $93,1 \%$ das variações das rachaduras.

Tabela 42. Nivel de significância entre as rachaduras em função dos encurvamentos.

\begin{tabular}{lclrlc}
\hline \multicolumn{1}{c}{ Espécie } & $\operatorname{Pr}>\mathrm{F}$ & \multicolumn{1}{c}{ Espécie } & $\mathrm{Pr}>\mathrm{F}$ & \multicolumn{1}{c}{ Espécie } & $\mathrm{Pr}>\mathrm{F}$ \\
\hline E. microcorys & 0,704 & E. paniculata & 0,152 & E. pellita & 0,468 \\
E. propinqua & 0,266 & E. resinifera & 0,468 & E. saligna & 0,329 \\
E. tereticornis & 0,704 & E. urophylla & 0,704 & E. cloeziana & 0,0001 \\
E. pilularis & 0,623 & E. phaeotricha & 0,257 & E. pyrocarpa & 0,329 \\
E. citriodora & 0,704 & E. maculata & 0,396 & E. toreliana & 0,468 \\
\hline
\end{tabular}


A Figura 44 que apresenta a dispersão dos dados em torno das regressões calculadas, mostra que dentro das espécies a correlação entre o encurvamento è o índice de rachadura de extremidade de tábua é ainda mais fraca que dentro do gênero Eucalyptus.
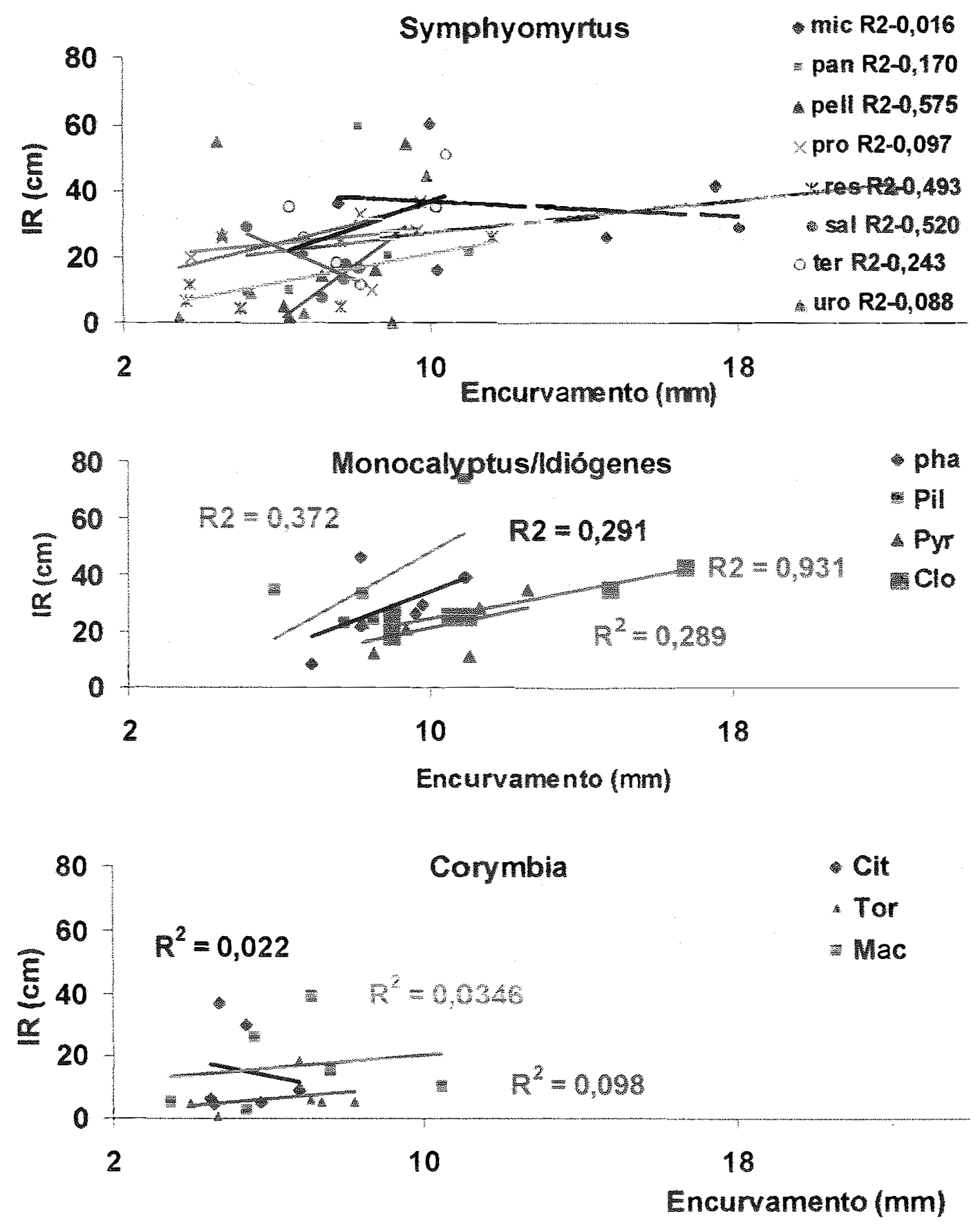

Figura 44 - Relação entre Rachaduras de extremidade de tábuas (IR) e encurvamento, dentro de espécies de Eucalyptus. 


\subsection{6 índice de rachadura de extremidade de tábuas (IR) e diâmetro}

A figura 45 mostra que não houve correlação significativa entre o indice de rachaduras e o diâmetro médio das toras sem casca.

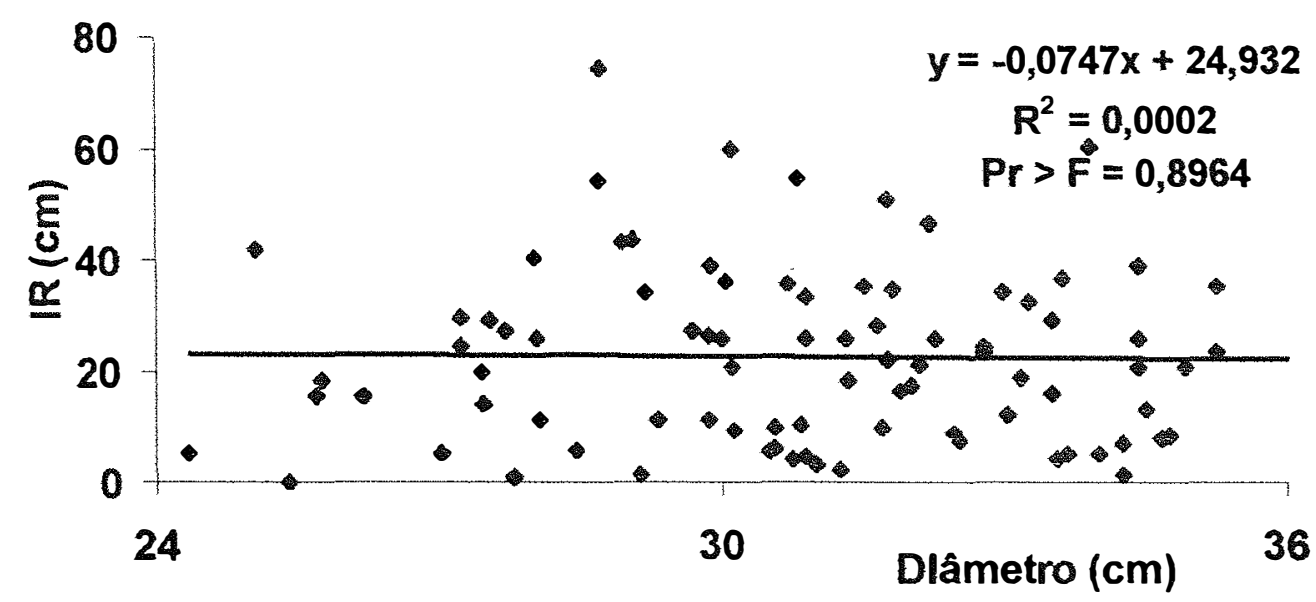

Figura 45 - Índice de rachadura de extremidade das tábuas em função dos diâmetro médio da tora, para o conjunto das 90 toras de 15 espécies de Eucalyptus.

A Tabela 43 e a Figura 46 mostram que essa constatação também é válida dentro de todas as espécies.

Tabela 43. Nível de significância entre, as rachaduras e os diâmetros.

\begin{tabular}{lclclc}
\hline \multicolumn{1}{c}{ Espécie } & $\operatorname{Pr}>\mathrm{F}$ & \multicolumn{1}{c}{ Espécie } & $\mathrm{Pr}>\mathrm{F}$ & \multicolumn{1}{c}{ Espécie } & $\mathrm{Pr}>\mathrm{F}$ \\
\hline E. microcorys & 0,468 & E. paniculata & 0,354 & E. pellita & 0,623 \\
E. propinqua & 0,704 & E. resinifera & 0,872 & E. saligna & 0,623 \\
E. tereticornis & 0,208 & E. urophylla & 0,396 & E. cloeziana & 0,208 \\
E. pilularis & 0,957 & E. phaeotricha & 0,872 & E. pyrocarpa & 0,787 \\
E. citriodora & 0,208 & E. maculata & 0,156 & E. toreliana & 0,704 \\
\hline
\end{tabular}

A intensidade de ocorrência de rachaduras nas extremidades das tábuas, são independentes do diâmetro médio das toras. 

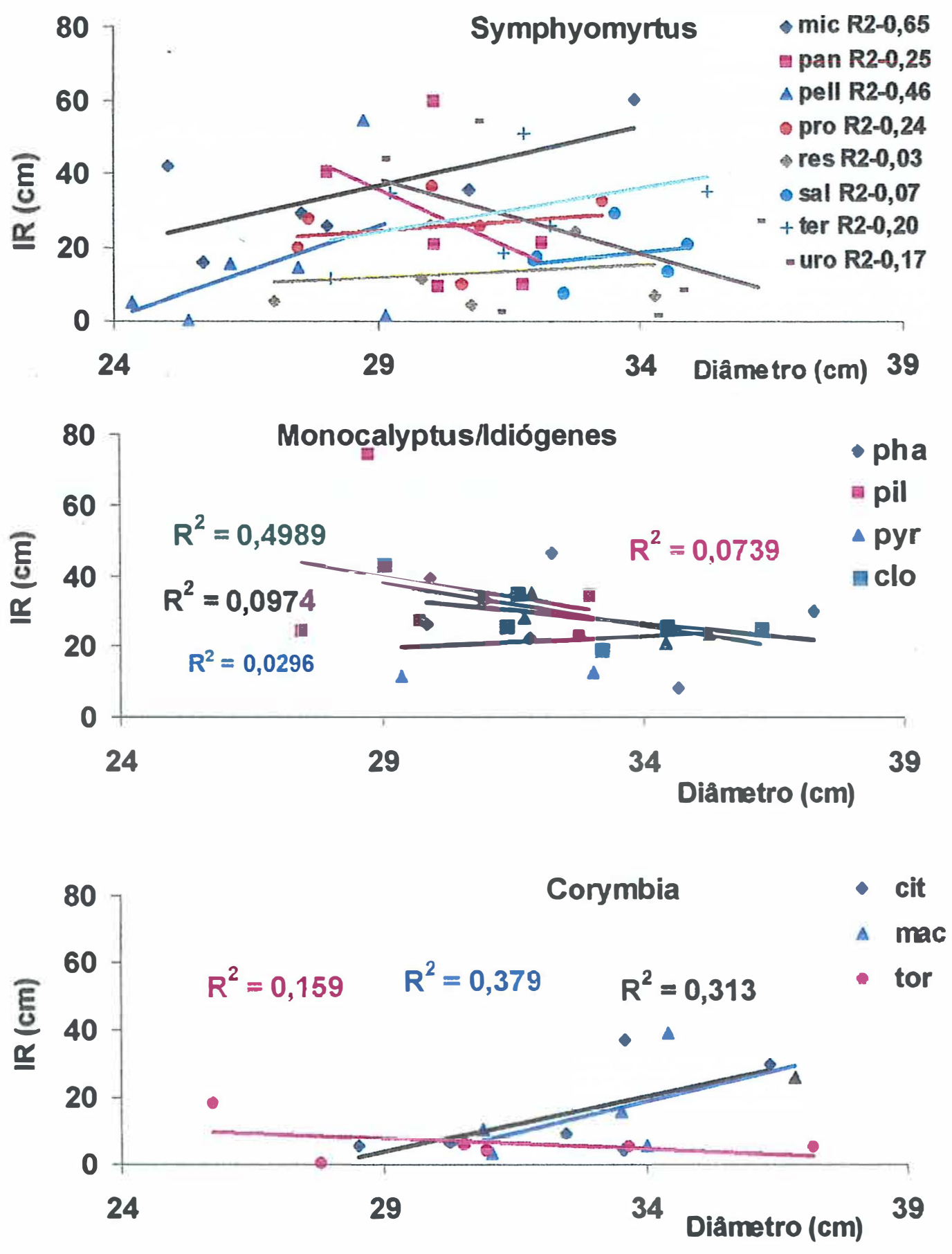

Figura 46 - Índice de Rachadura de extremidade de tábua em função do diâmetro, dentro de espécie e de subgênero. 


\subsubsection{Encurvamento e diâmetro}

Verifica-se uma associação entre o diâmetro das toras e encurvamento das tábuas. Portanto, há evidência ao nível de $5 \%$ de significância, de que os encurvamentos das tábuas estão associados com o diâmetro das toras, para as quinze espécies de eucaliptos.

A Tabela 37 e a Figura 47 mostram a correlação entre o encurvamento e o diâmetro da tora é significativa. Isso diminui com o aumento do diâmetro da tora. Entretanto o diâmetro responde por apenas $11,5 \%$ da variação do encurvamento.

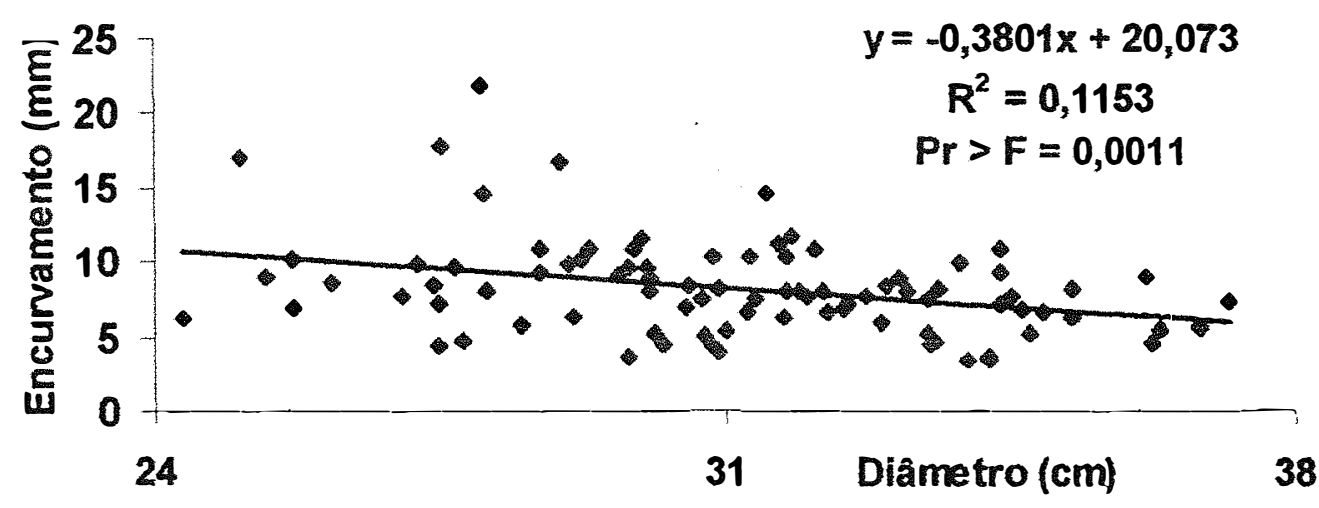

Figura 47 - Encurvamento das tábuas em função do diâmetro das toras, nas quinze espécies de Eucalyptus.

A Tabela 44 e a Figura 48 mostram que apenas no $E$. pilularis e no $E$. phaeotricha foram encontradas correlações significativas entre essas variáveis. Nessas correlações os diâmetros responderam por 52,3 e 63,8 \% respectivamente, da variação dos encurvamentos.

Tabela 44. Nivel de significância entre os encurvamentos em função dos diâmetros das quinze espécies de eucalipto.

\begin{tabular}{llllll}
\hline \multicolumn{1}{c}{ Espécie } & $\mathrm{Pr}>\mathrm{F}$ & \multicolumn{1}{c}{ Espécie } & $\operatorname{Pr}>\mathrm{F}$ & Espécie & $\mathrm{Pr}>\mathrm{F}$ \\
\hline E. microcorys & 0,156 & E. paniculata & 0,500 & E. pellita & 0,704 \\
E. propinqua & 0,957 & E. resinifera & 0,329 & E. saligna & 0,110 \\
E. tereticornis & 0,208 & E. urophylla & 0,468 & E. cloeziana & 0,208 \\
E. pilularis & 0,042 & E. phaeotricha & 0,050 & E. pyrocarpa & 0,110 \\
E. citriodora & 0,791 & E. maculata & 0,468 & E. toreliana & 0,110 \\
\hline
\end{tabular}



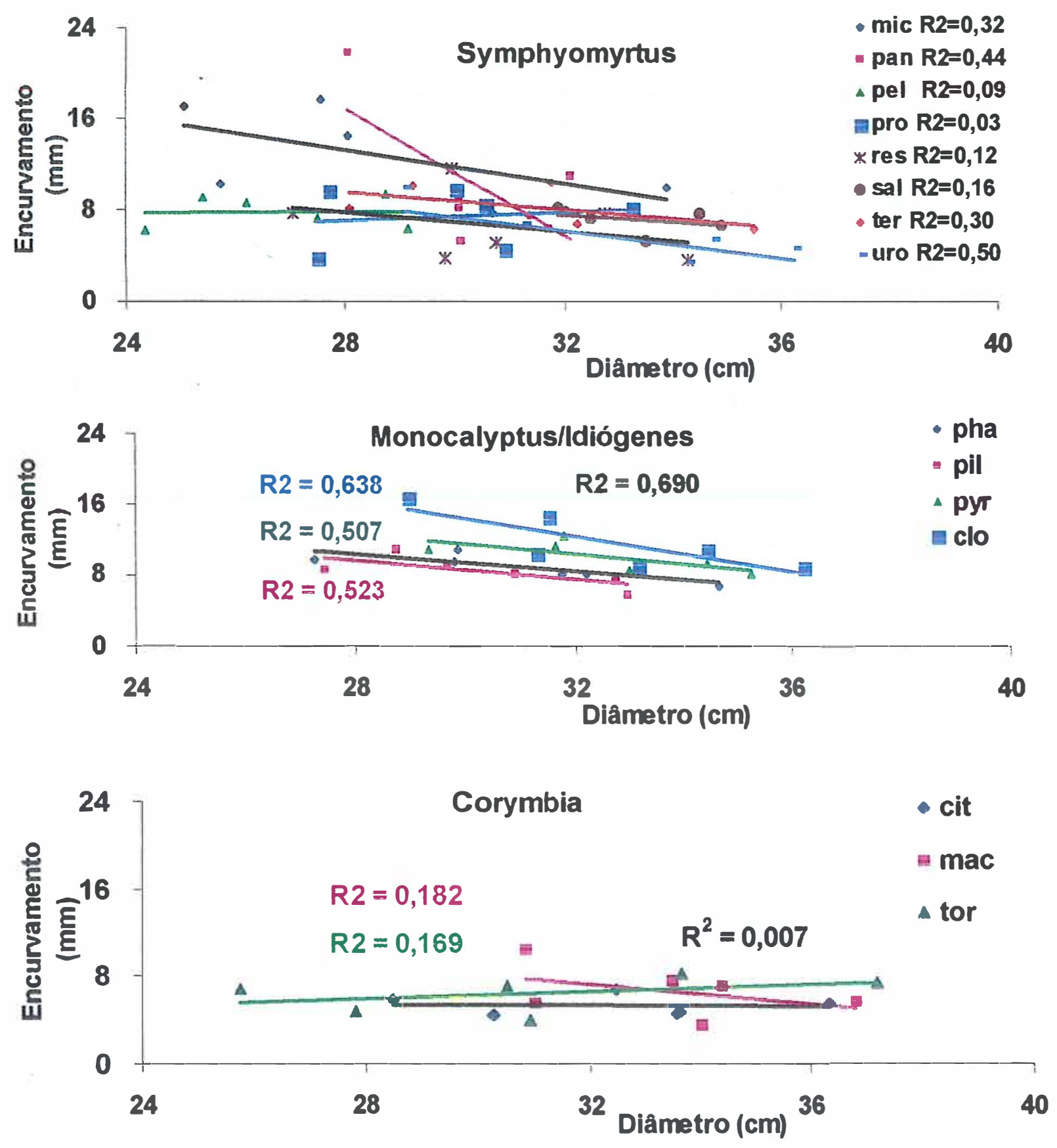

Figura 48 - Encurvamento em função do diâmetro médio da tora, dentro das espécies. 


\subsection{Dureza da madeira}

Os valores de dureza (Janka) das quinze espécies de Eucalyptus estão apresentados na tabela 43 . Os resultados foram medidos no sentido normal às fibras, a uma umidade de equilibrio próxima de $14,6 \%$.

Tabela 45. Dureza (Janka), médias em (Mpa), das quinze espécies de Eucalyptus, na condição seca ao ar.

\begin{tabular}{lcccccc}
\hline Espécie Eucalyptus & Média & Máxima & Mínima & s & CV (\%) & $S_{\mathbf{x}}$ \\
\hline E. pellita & 141,9 & 160 & 118 & 112,2 & 7,90 & 24,47 \\
E. tereticornis & 135,8 & 150 & 116 & 95,4 & 7,04 & 21,3 \\
E. paniculata & 132,6 & 154 & 120 & 98,3 & 7,39 & 19,67 \\
E. pyrocarpa & 130,8 & 176 & 80 & 286,8 & 21,96 & 64,13 \\
E. propinqua & 130,4 & 148 & 118 & 16,4 & 1,26 & 16,44 \\
E. phaeotricha & 126,6 & 136 & 114 & 58,1 & 4,59 & 12,98 \\
E. cloeziana & 124,6 & 150 & 96 & 141,4 & 11,44 & 29,47 \\
E. citriodora & 122,9 & 136 & 110 & 70,2 & 5,70 & 14,63 \\
E. maculata & 113,6 & 130 & 92 & 87,2 & 7,68 & 19,50 \\
E. urophylla & 106,0 & 118 & 94 & 57,4 & 5,41 & 12,80 \\
E. pilularis & 101,4 & 118 & 84 & 114,0 & 11,24 & 25,49 \\
E. toreliana & 98,7 & 110 & 88 & 65,5 & 6,64 & 13,10 \\
E. saligna & 91,2 & 106 & 70 & 92,3 & 10,12 & 20,60 \\
E. resinifera & 78,0 & 95 & 68 & 75,6 & 9,69 & 16,10 \\
E. microcorys & 62,1 & 82 & 44 & 96,3 & 15,88 & 21,52 \\
\hline s = Desvio padrão & CV Coeficiente de variação & S S = erro padrão da média
\end{tabular}

Verificam-se baixos coeficientes de variação dentro das espécies. O E. microcorys e o E. pyrocarpa foram as espécies que apresentaram as maiores heterogeneidades nos resultados com coeficientes de variação de $15,88 \%$ e $21,96 \%$ respectivamente. No caso do $E$. pyrocarpa, esse comportamento pode ser atribuído influência de uma amostra de madeira que situava-se na região da medula. A resistência média de dureza no lenho juvenil foi de $90,3 \mathrm{MPa}$, e 143,7 no lenho adulto, uma resistência significando uma dureza de aproximadamente $37 \%$ maior.

Oliveira (1997) e Ponce (1995) afirmam que, o lenho juvenil, apresenta fibras mais curtas e de menor densidade que o lenho normal, consequentemente sua resistência mecânica é inferior. 
Tabela 46. Comparação múltipla de Bonferroni, da Dureza da madeira, entre os subgêneros de Eucalyptus.

\begin{tabular}{lcc}
\hline Causas de variação & Dureza (MPa) & Grupo (1) \\
\hline Idiogenes & 123,6 & $\mathrm{a}$ \\
Monocalyptus & 119,5 & $\mathrm{ab}$ \\
Corymbia & 110,1 & $\mathrm{ab}$ \\
Symphyomyrtus & 110,0 & $\mathrm{~b}$
\end{tabular}

(1) Médias com a mesma letra não são significativamente diferentes entre si..

(2) $\mathrm{CV}=21,81 \%$

A tabela 47 mostra uma grande estratificação dentro do gênero e também dentro dos subgêneros. A comparação das médias de dureza, pelo teste de Bonferroni ao nivel de $5 \%$ de probabilidade, mostrou que existem diferenças significativas entre os subgêneros. $O$ ldiogenes difere significativamente do Symphyomyrtus. O Monocalyptus e o Corymbia não diferem entre si e se assemelham aos outros dois.

Tabela 47. Durezas das quinze espécies de Eucalyptus, dentro dos subgêneros e gênero.

\begin{tabular}{|c|c|c|c|c|c|}
\hline Subgênero & Espécies & $\begin{array}{l}\text { Dureza } \\
\text { (Mpa) }\end{array}$ & $\begin{array}{l}\text { Espécie dentro de } \\
\text { Subgênero (1) }\end{array}$ & $\begin{array}{l}\text { Espécies den } \\
\text { gênero }\end{array}$ & \\
\hline Symphyomyrtus & $\begin{array}{l}\text { E. pellita } \\
\text { E. tereticornis } \\
\text { E. paniculata } \\
\text { E. propinqua } \\
\text { E. urophylla } \\
\text { E. saligna } \\
\text { E. resinifera } \\
\text { E. microcorys }\end{array}$ & $\begin{array}{c}142 \\
136 \\
132 \\
130 \\
106 \\
91 \\
78 \\
62\end{array}$ & $\begin{array}{c}a \\
b a \\
b \\
b \\
c \\
d \\
e \\
f\end{array}$ & $\begin{array}{l}\text { E. pellita } \\
\text { E. tereticomis } \\
\text { E. paniculata } \\
\text { E. pyrocarpa } \\
\text { E. propinqua } \\
\text { E. phaeotricha } \\
\text { E. cloeziana } \\
\text { E. citriodora }\end{array}$ & $\begin{array}{c}\mathrm{a} \\
\mathrm{ba} \\
\mathrm{bac} \\
\mathrm{bac} \\
\mathrm{bac} \\
\mathrm{bc} \\
\mathrm{bdc} \\
\mathrm{dc}\end{array}$ \\
\hline Monocalyptus & $\begin{array}{l}\text { E. pyrocarpa } \\
\text { E. phaeotricha } \\
\text { E. pilularis }\end{array}$ & $\begin{array}{l}131 \\
126 \\
101\end{array}$ & $\begin{array}{l}a \\
a \\
b\end{array}$ & $\begin{array}{l}\text { E. maculata } \\
\text { E. urophylla } \\
\text { E. pilularis }\end{array}$ & $\begin{array}{l}\text { ed } \\
\text { ef } \\
\text { eg }\end{array}$ \\
\hline Corymbia & $\begin{array}{l}\text { E. citriodora } \\
\text { E. maculata } \\
\text { E. torelliana }\end{array}$ & $\begin{array}{c}123 \\
113 \\
99\end{array}$ & $\begin{array}{l}a \\
b \\
c\end{array}$ & $\begin{array}{l}\text { E. torelliana } \\
\text { E. saligna } \\
\text { E. resinifera }\end{array}$ & $\begin{array}{r}f g \\
g \\
h\end{array}$ \\
\hline Idiogenes & E. cloeziana & 124 & & E. microconss & $i$ \\
\hline
\end{tabular}

(1) Médias com a mesma letra não são significativamente diferentes 
Verifica-se que dentro do subgênero Symphyomyrtus, o E. pellita só é igual ao E. tereticornis. $O E$. tereticornis, E. paniculata e $\circ E$. propinqua não diferem significativamente entre si. Todas as demais espécies, são estatisticamente diferentes de todas as outras.

O mesmo acontece no subgênero Corymbia onde, as três espécies diferem significativamente entre si. No Monocalyptus o $E$. pyrocarpa é igual ao E. phaeotricha, e ambas diferem significativamente do E. pilularis.

Dentro do gênero Eucalyptus as espécies também podem ser subdivididas em grupos menores do que os subgêneros. $O E$. pellita, $E$. tereticornis, E. paniculata E. pyrocarpa e o E. propinqua formam um grupo superior apresentando as maiores durezas. O E. microcorys é a espécie de menor dureza e difere significativamente de todas as outras espécies. As demais espécies formam pequenos subgrupos intermediários, com diferenças significativas, entre subgrupos.

A Figura 49 representa graficamente a dureza média da madeira das quinze espécies de Eucalyptus.

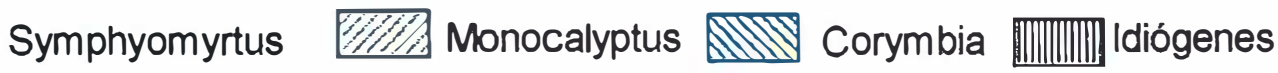

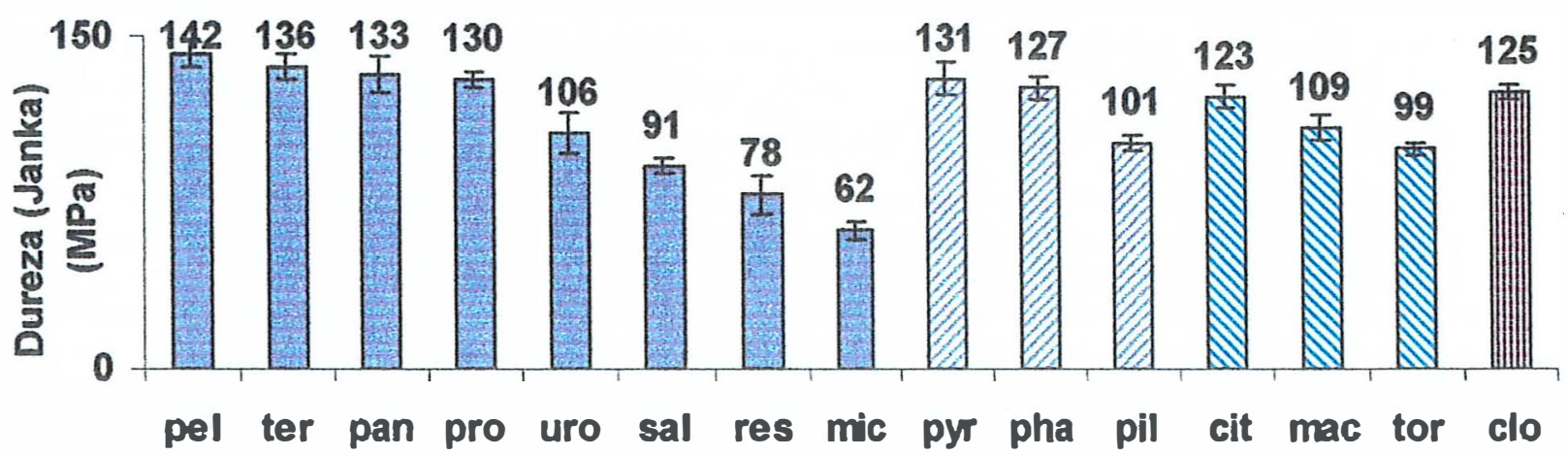

Figura 49 - Dureza na direção normal às fibras, de quinze espécies de Eucalyptus.

A Figura 50, mostra as quinze espécies de Eucalyptus classificados em classes de dureza. Verifica-se que a maioria das madeiras deste gênero situamse de dureza alta, demonstrando que este gênero é adequado a trabalhos que 
exigem resistência a esforços de puncionamento como assoalhos, tacos, cunhas, roletes, bolas para jogos e móveis.

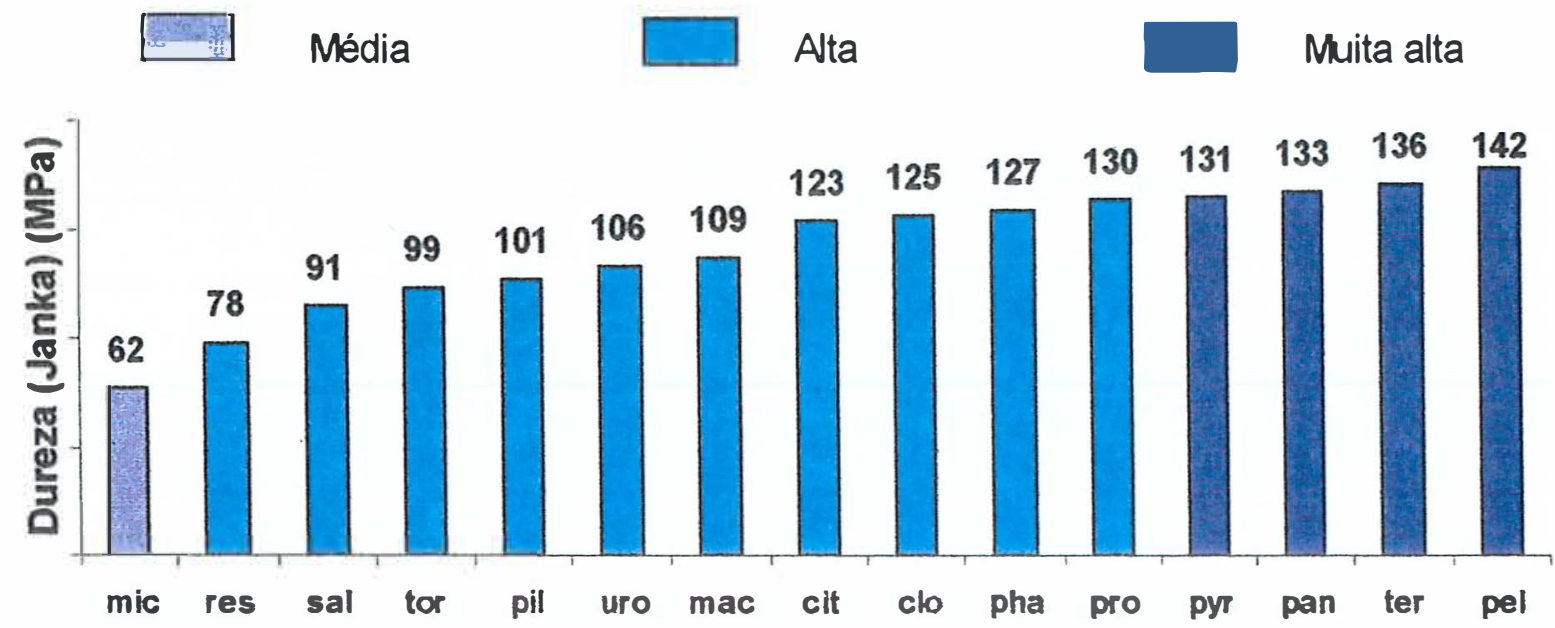

Figura 50 - Classificação do Eucalyptus em classes de dureza.

\subsection{Aparência da madeira}

A maioria das espécies de Eucalyptus tem pronunciada diferença de cor entre o cerne e Alburno, o qual pode ser um inconveniente quando se busca a homogeneidade de cores das peças.

A figura 34 apresenta o espectro de cores e suas variações, observadas entre nas 15 espécies de Eucalyptus. No subgênero Symphyomyrtus ocorre a predominância da cor avermelhada, sendo o $E$. pellita, a de tonalidade mais acentuada. O E. tereticornis, E. urophylla, E. propinqua, E. paniculata, E. saligna e o E. resinifera, apresentam uma tonalidade avermelhada cada vez mais fraca, tendendo para o róseo do mogno. O E. microcorys é uma exceção nesse subgênero, apresentando uma cor parecida com a do pau-marfim, é a espécie de cor mais clara de todas as quinze espécies.

No subgênero Monocalyptus e no $E$. cloeziana, predomina a cor castanha clara, assemelhando-se ao louro-aritu amazônico. 


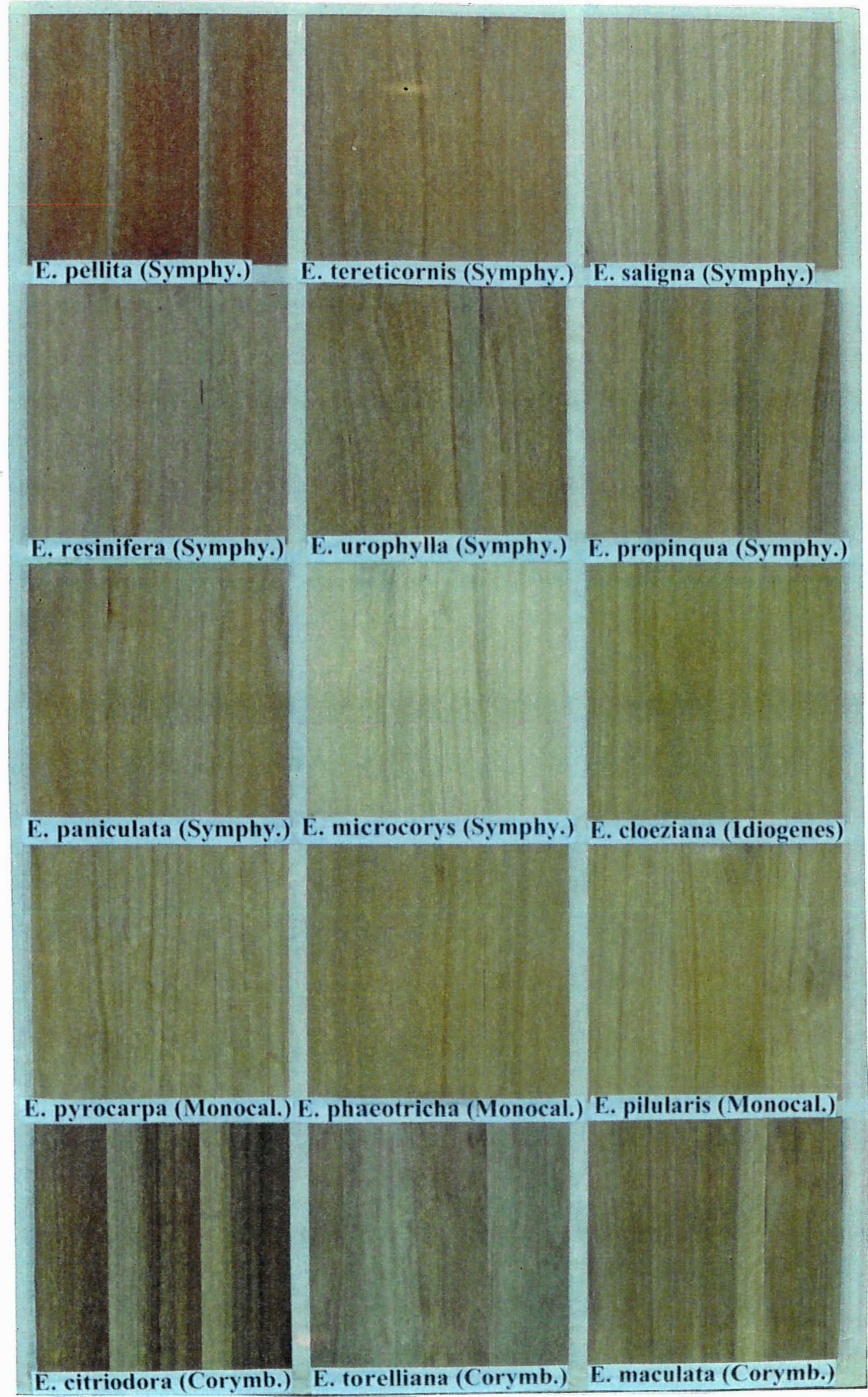

Figura 51 - Aparência da madeira das 15 espécies de Eucalyptus. 
No subgênero Corymbia, verifica-se a mais pronunciada diferença entre cerne e alburno, com predominância da cor castanha clara no alburno a castanha escura no cerne, assemelhando-se ao ipê. HILLIS \& BROWN (1978), afirmam que tanto o $E$. maculata como o E. citriodora tendem a apresentar formação de bolsas de resina. Estas bolsas foram encontradas nessas espécies, afetando a aparência da madeira. Segundo os mesmos autores acima este defeito está associado a fortes deficits hídricos, comum em certos períodos do ano na região de Anhembi-SP.

No mercado de artefatos de madeira, as espécies mais comercializadas eram as nativas, especialmente a araucaria e imbuia na região sul do Brasil, por apresentar vantagens como aparência, fácil trabalhabilidade e resistência mecânica. Atualmente existe uma busca de madeiras alternativas e que possuam cor avermelhada por ser a de maior aceitação no mercado.

As aparência da madeira sofre alterações em função dos cruzamentos, clima, solo e tempo de exposição na atmosfera.

Outro aspecto de grande importância em relação à cor, é a homogeneidade entre o cerne e alburno. De acordo com Assis (1999), em certas situações e uso, essas características podem ser valorizadas. Existem espécies que são naturalmente mais homogêneas em relação à coloração, como as espécies do subgênero Monocalyptus utilizadas nesse estudo. $O E$. microcorys e o E. cloeziana, também são espécies que apresentaram fraca diferenciação entre cerne e albumo. Em geral, as espécies que apresentam coloração mais clara no cerne, são mais homogêneas na sua coloração.

As árvores do $E$. torelliana utilizadas nesse estudo provavelmente eram hibridas com E. citriodora. Podem decorrer desse fato os excelentes resultados, que elas apresentaram. Além de ser a espécie que menos rachou, apresentou crescimento satisfatório produzindo madeiras de cor parecida com a do ipê sem os inconvenientes dos canais resiníferos do $E$. maculata e do próprio $E$. citriodora. 
O E. microcorys, além de apresentar uma cor clara e de boa aparência para assoalhos, apresenta elevada durabilidade, mesmo estando em contato com o solo, (Oliveira, 1999).

As madeiras de eucalipto, provenientes de árvores de idades mais avançadas, são potenciais substitutas das madeiras nativas, de uso tradicional na industria civil. Entretanto, devem atingir o seu ponto de maturação, para produzirem de madeira com propriedades mais estáveis. Embora sejam consideradas espécies de rápido crescimento, existe uma idade ótimo para seu beneficiamento em serrarias, que segundo a literatura é em torno dos 25 anos. São também muito importantes as práticas silviculturais, principalmente a desrama bem conduzida, para obter-se uma madeira limpa, de melhor aparência e qualidade, de maior valor agregado e de melhor aproveitamento nos inúmeros empreendimentos da sociedade.

\subsection{Comparação das espécies}

A madeira serrada de melhor qualidade é aquela que apresenta menos defeitos e apresenta uma combinação de características específicas que permitem seu melhor aproveitamento para um determinado uso específico.

Existem defeitos que são intrínsecos da madeira de uma ou de outra espécie, como por exemplo a presença de bolsas de resina, teor de alburno, cor, lenho juvenil, cerne quebradiço, inclinação da grã, rachaduras de extremidades das tábuas, empenamentos e algumas heterogeneidades físicas e mecânicas.

Alguns defeitos inerentes à madeira podem ser minimizados através de um manejo adequado. Os nós mesmo sendo considerados uma característica intrínseca, é facilmente manejável, através da desrama. A casca não pode ser considerada como defeito nas toras, mas é indesejável nos processo industriais. 
Quando presente na madeira serrada e outros laminados, afeta a qualidade do produto e este perde valor comercial.

De acordo com Kikuti et al (1996), a escolha da espécie mais adequada para finalidade a qual se deseja é de fundamental importância, em função da heterogeneidade da madeira existente entre as diferentes espécies. Neste aspecto, além das características físicas e mecânicas, que variam de uma espécie para outra, devem ser considerados os fatores intrínsecos, que são características que influenciam diretamente na qualidade e aparência do produto final.

Assim, a adequação e otimização do uso da madeira está estreitamente relacionada à sua classificação, visando obter os materiais mais adequados, com qualidade garantida. Segundo Kikuti et al (1996), o estabelecimento de classes e procedimentos de classificação permite um melhor relacionamento comercial e atendimento das necessidades sociais. Geralmente os métodos de classificação são baseados na quantificação e na ponderação da importância dos defeitos encontrados na peça de madeira.

O presente trabalho quantificou uma série de defeitos encontrados na madeira de várias espécies de eucaliptos, os quais podem se tornar indicadores de qualidade por afetarem o rendimento em madeira serrada e principalmente, a qualidade visual das tábuas. Entre todos os defeitos observados, os que mais se sobressaíram foram as rachaduras de extremidades das tábuas, incidência de nós e desuniformidades das dimensões das tábuas. Os encurvamentos foram facilmente minimizados na secagem.

As Figuras 52 e 53 mostram os resultados da somatória de todas as variáveis estudadas, podendo-se visualizar, comparativamente, o quanto cada defeito contribui na qualidade global da madeira dentro de cada espécie. 


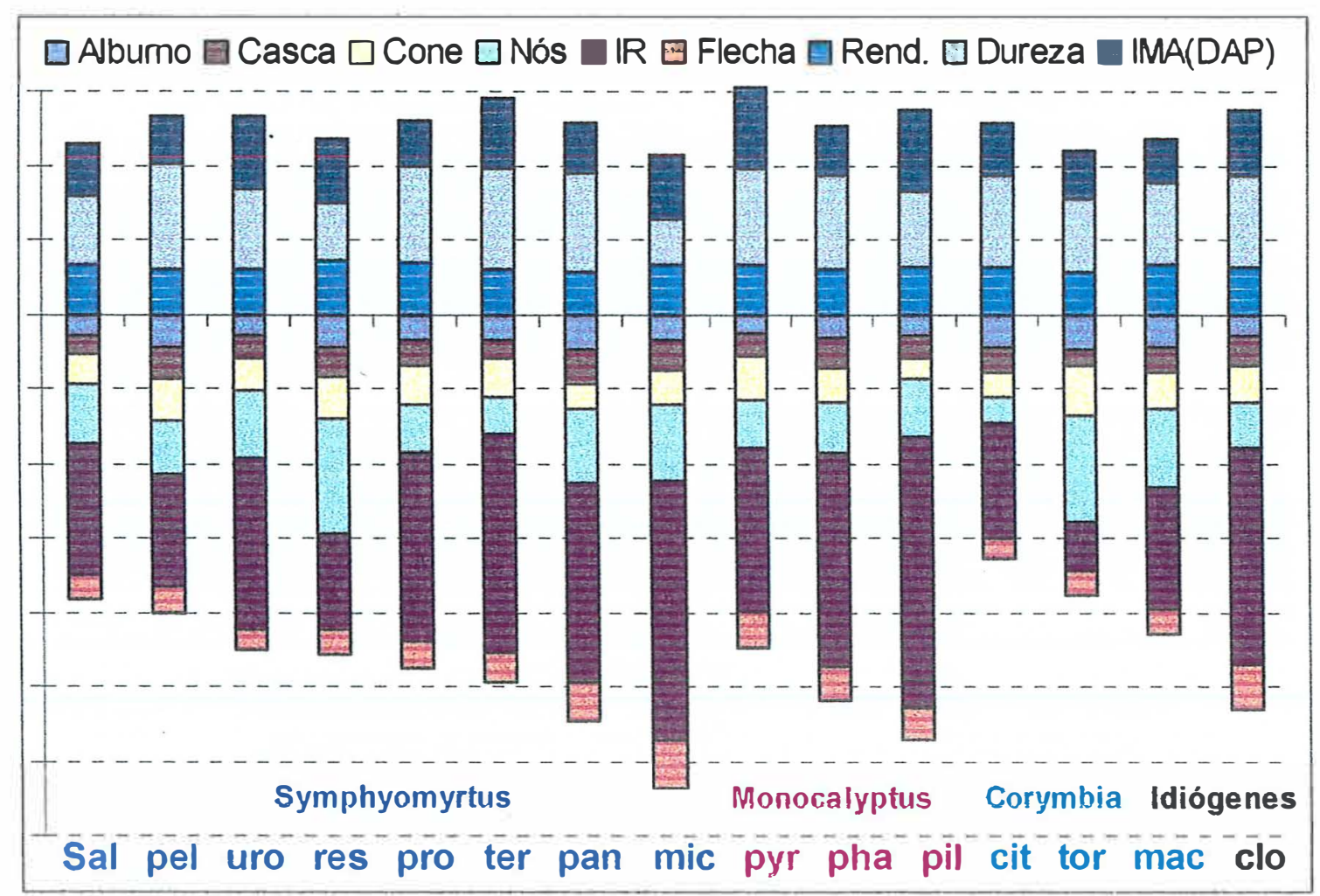

Figura 52 - Defeitos e qualidades acumulados, na madeira serrada de Eucalyptus, em ordem crescente de negatividade dentro dos subgêneros.

Para a construção destes gráficos, os valores observados foram transformados de acordo com os coeficientes de ajuste da Tabela 48, buscando-se colocar em maior evidência os indices de rachaduras de extremidades de tábuas e a incidência de nós, que são os principais responsáveis pela perda de qualidade da madeira.

Tabela 48. Fatores de ajuste utilizado para hierarquizar os defeitos e qualidades de Eucalyptus para produção de madeira serrada.

\begin{tabular}{lclclc}
\hline Variável & Fator & Variável & Fator & Variável & Fator \\
\hline Rendimento & $1 / 10$ & IMA & $\times 5$ & Dureza & $1 / 5$ \\
Alburno & $1 / 10$ & Casca & $1 / 5$ & Conicidade & $\times 5$ \\
Nós & $1 / 2$ & IR & $\times 1$ & Encurvam. & $1 / 2$ \\
\hline
\end{tabular}

Acima do eixo $x$, encontram-se os rendimentos, dureza e IMA (DAP), consideradas como parâmetros positivos na qualidade da madeira. Abaixo do 
eixo $x$ encontram-se os defeitos, considerados como fatores negativos na qualidade da madeira. Nota-se que as espécies de menor negatividade são o $E$. citriodora, E. toreliana, E. saligna e o E. pellita. Podem ser consideradas dentre as 15 espécies estudadas, como as melhores para a produção de madeira serrada.

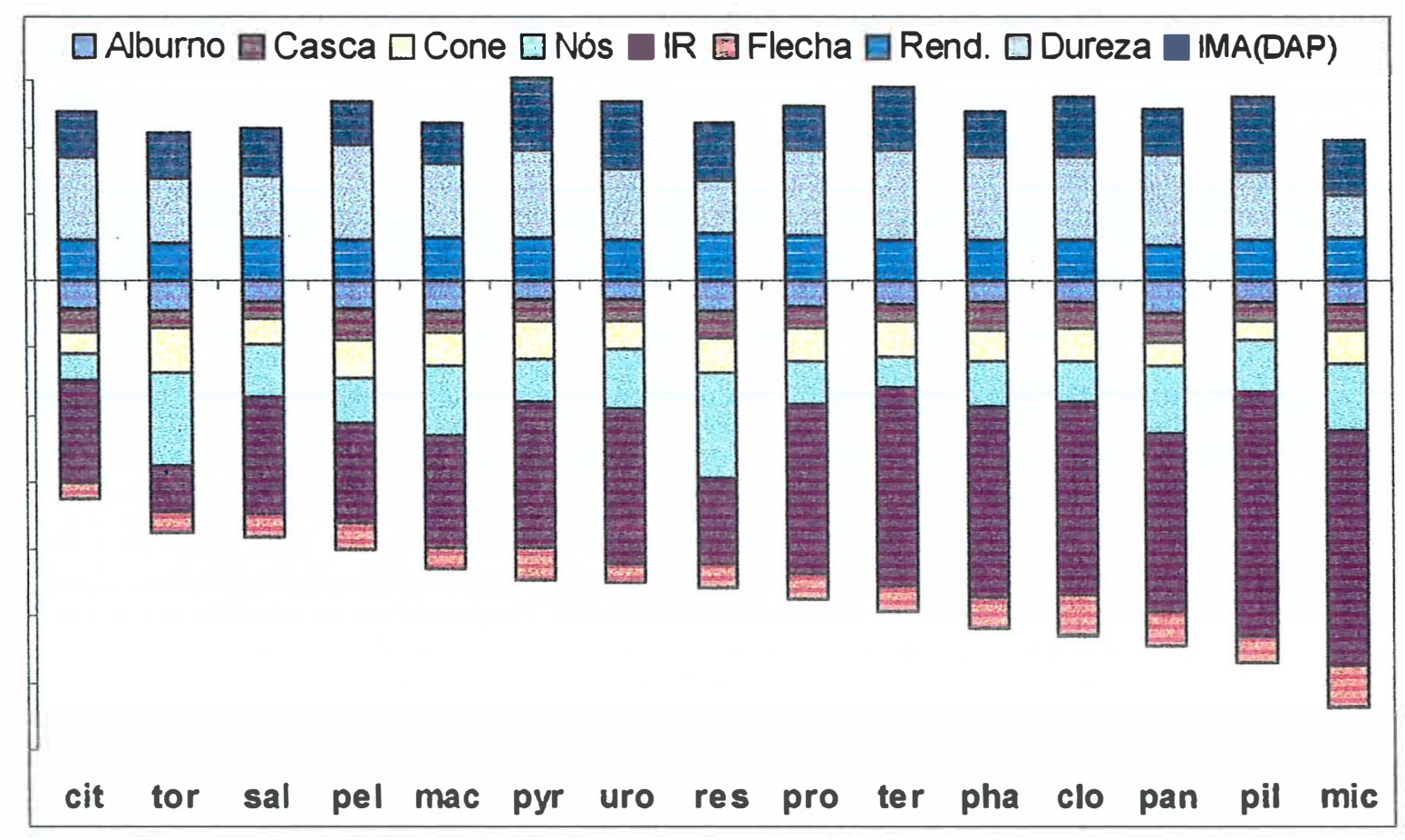

Figura 53 - Defeitos acumulados na madeira serrada de Eucalyptus, hierarquizado no gênero.

Em contrapartida as espécies que apresentaram os maiores índices de defeitos foram o E. microcorys, E. pilularis, E. cloeziana e o E. paniculata, não sendo recomendadas como produtoras de madeira serrada.

O E. torelliana embora tenha apresentado o menor índice de rachaduras de extremidade das tábuas (IR) perde, no cômputo geral para o E. citriodora, por apresentar alta incidência de nós nas tábuas e maior percentagem de casca. $O$ mesmo acontece com o E. resinifera que embora tenha apresentado um baixo $\mathrm{IR}$, apresentou a maior incidência de nós entre todas as espécies. Eliminando-se o problema dos nós através de uma desrama adequada essas espécies passam a apresentar um grande potencial para serem exploradas comercialmente. Ao 
contrário do $E$. resinifera aconteceu com o E. tereticornis, que apresentou uma das maiores incidência de rachadura de extremidade de tábuas com 29,31 cm, mas apresentou uma das mais baixa incidência de nós, levando vantagem nesta variável no cômputo geral.

Observa-se na Figura 53 que o rendimento em madeira desdobrada, o incremento médio anual do diâmetro e a dureza da madeira em conjunto, não apresentam, individualmente ou no conjunto como um todo, grande variabilidade, influindo muito pouco na hierarquização das espécies.

Do lado dos defeitos observa-se grande variabilidade das rachaduras de extremidades de tábuas e da incidência de nós. Os demais defeitos como a conicidade, casca e alburno são mais homogêneas entre as espécies.

$\mathrm{Na}$ Figura 54 mostra que a percentagem de alburno, percentagem de casca e conicidade, praticamente não se alteram entre os subgêneros, não se caracterizando como importantes para hierarquiza-los. Em contrapartida observa-se uma maior dispersão da incidência de nós, índice de rachaduras de extremidade de tábuas e encurvamento da tábua, permitindo apontar o Corymbia como o subgênero de melhor potencial, para a produção de madeira serrada.

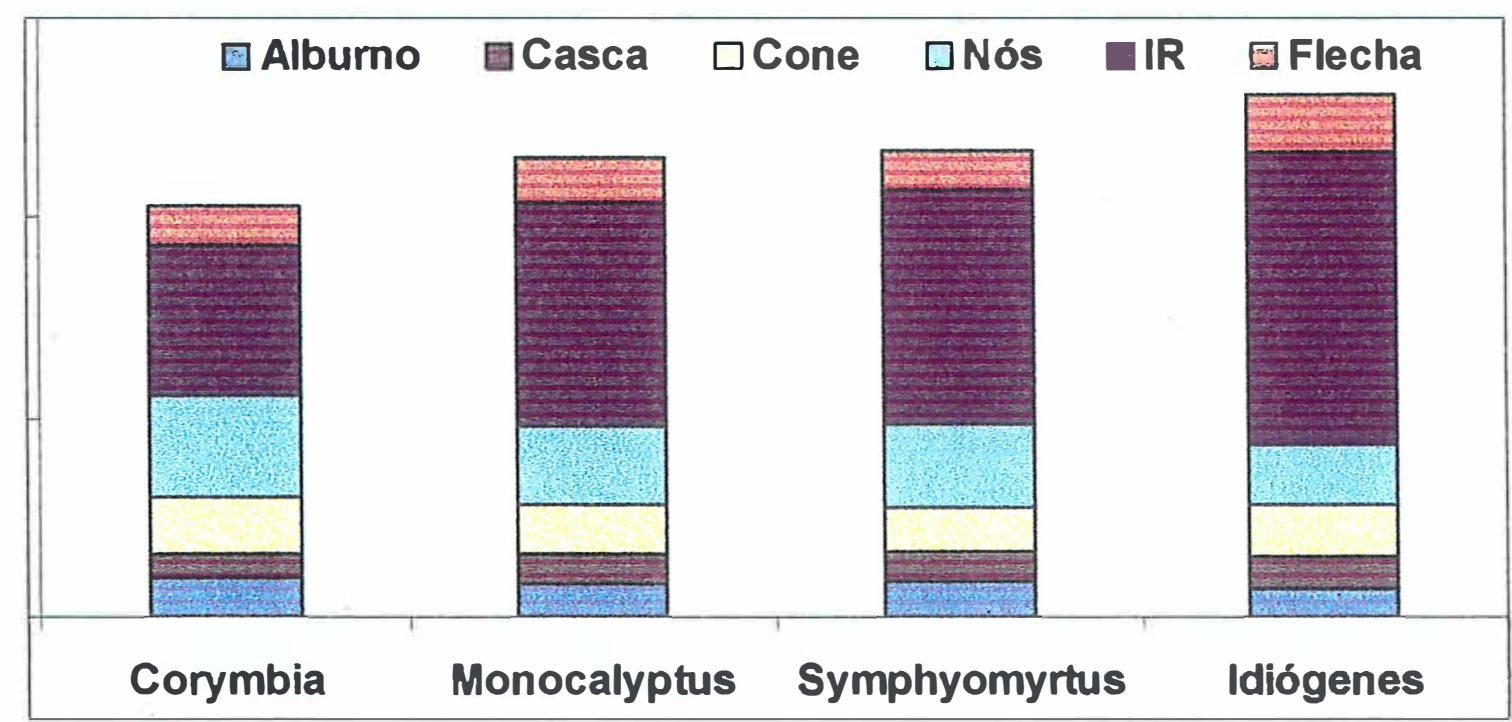

Figura 54 - Defeitos na madeira serrada de Eucalyptus, entre os subgêneros. 


\section{CONCLUSÕES}

Os resultados obtidos no presente estudo permitem concluir 0 seguinte:

\section{Alburno}

- As espécies que apresentam as maiores percentagens de alburno em ordem decrescente, foram o E. paniculata, 47,91\%; E. toreliana, 46,51 \%; E. maculata, $45,38 \%$ e 0 E. resinifera, $45,36 \%$ e diferem estatisticamente do grupo do $E$. saligna, 30,26 \%; E. cloeziana, 29,51\%; $E$. urophylla, 29,08 \%; e E. pyrocarpa, 26,43 \% que apresentou a menor percentagem de alburno.

- As toras da base diferem significativamente das toras superiores. Nas quinze espécies estudadas a percentagem de alburno aumentou da altura de 2,0 $\mathrm{m}$ para a altura de 7,6 $\mathrm{m}$ na árvore.

- Existem diferenças significativas entre os subgêneros. $O$ Corymbia e Symphyomyrtus são iguais, mas diferem do Monocalyptus e do Idiogenes que também são iguais.

- Apenas dentro do subgênero Symphyomyrtus, existe diferença significativa entre as espécies. OE. paniculata, E. resinifera e o E. pellita apresentam maiores quantidades de alburno e diferem significativamente do E. propinqua, E. microcorys, E. tereticornis, E. saligna, E. urophylla. Essas cinco ultimas não diferem estatisticamente entre si. 


\section{Casca}

- As espécies com as maiores percentagens de casca são o $E$. paniculata, $18,03 \%$ e o E. pellita, $17,80 \%$ que diferem significativamente das espécies com as menores percentagens de casca que são: o $E$. saligna, $10,02 \%$; E. tereticornis, $9,88 \%$ e o E. toreliana com $9,34 \%$.

- A tora da base difere significativamente da tora subsequente. A percentagem de casca aumenta com o aumento da altura na árvore. Apenas o E. microcorys e o E. cloeziana apresentaram um comportamento inverso, diminuíram a percentagem de casca com o aumento da altura na árvore.

- Não existem diferenças significativas da percentagem média de casca entre os subgêneros.

- No subgênero Symphyomyrtus há o predomínio de casca fibrosa e apenas o E. paniculata apresentou a maior percentagem de casca e difere significativamente do E. saligna e do E. tereticornis.

- Tanto no subgênero Monocalyptus de cascas fibrosas, como no Corymbia de casca lisa, as quantidades de casca não diferem significativamente entre si.

Conicidade

- A espécie de menor conicidade foi o E. pilularis e as espécies de maiores conicidades foram o $E$. toreliana, $1,36 \mathrm{~cm} / \mathrm{m} ; E$. pyrocarpa, 1,17 $\mathrm{cm} / \mathrm{m}$ e o E. pellita, $1,12 \mathrm{~cm} / \mathrm{m}$. Com exceção do E. pilularis todas as demais espécies formam um grupo, não diferindo entre si, demonstrando muito pouca variação de conicidade ente as 15 espécies de eucaliptos.

- Existem diferenças significativas entre as toras de base e a superior. A conicidade média da tora na posição da base de $1,24 \mathrm{~cm} / \mathrm{m}$ é praticamente o dobro da conicidade média da tora na posição adjacente superior de $0,66 \mathrm{~cm} / \mathrm{m}$. 
- Não existem diferenças significativas de conicidade entre os subgêneros, sugerindo que todos os subgêneros, em média, apresentam a mesma conicidade.

- Dentro do subgênero Monocalyptus o E. pilularis apresentou a menor conicidade e difere significativamente do $E$. pyrocarpa e do $E$. phaeotricha.

- Dentro dos subgêneros Symphyomyrtus e Corymbia não existem diferenças significativas de conicidade entre as espécies.

Nós

- A maior freqüência de nós ocorre nas tábuas próximas à região da medula, e vai diminuindo gradativamente, até chegar a zero, nas peças localizadas próximas à casca. Isso indica a necessidade de desrama artificial nos primeiros estágios de crescimento, para aumentar-se o número de peças serradas isentas de nós.

- As espécies com os maiores índices de ocorrência de nós por face de tábua são o E. resinifera com 7,75, E. toreliana, 6,97; E. maculata, 5,20 e o $E$. microcorys 5,08 . As espécies com menor ocorrência de nós na madeira serrada foram o E. pyrocarpa, 6,95; E. cloeziana, 6,06; E. tereticornis, 4,81; e o E. Citriodora com 3,62 nós por face.

- Não existe diferença significativa entre as posições das toras na árvore. Tanto a tora superior como a inferior apresentaram a mesma quantidade de nós na face da tábua em todas as espécies.

- Não existe diferença significativa de incidência de nós entre os subgêneros.

- No subgênero Symphyomyrtus, apenas o E. resinifera difere significativamente das demais espécies.

- Não existem diferenças significativas entre as espécins do subgênero Monocalyptus. 
- No Corymbia o E. toreliana e o E. maculata em conjunto, diferem significativamente do E. citriodora.

Rachadura de extremidade de tábua

- As rachaduras de extremidade de tábuas aumentam da casca para a medula.

- As espécies que mais racharam nas extremidades das tábuas, sugerindo que elas apresentam os maiores níveis de tensões de crescimento foram o $E$. pilularis, $36,28 \mathrm{~cm} ; E$. microcorys, $34,74 \mathrm{~cm} ; E$. tereticornis, $29,83 \mathrm{~cm}$; e o E. cloeziana, $29,09 \mathrm{~cm}$.

- Ao contrário as espécies que menos racharam foram o $E$. maculata, $16,52 \mathrm{~cm} ;$ E. citriodora, $15,30 \mathrm{~cm} ; E$. resinifera, $13,02 \mathrm{~cm}$ e o $E$. toreliana, $6,67 \mathrm{~cm}$.

- Existem diferenças significativas entre os subgêneros. $O$ Idiogenes e Monocalyptus em conjunto diferem do Corymbia. $O$ Symphyomyrtus é semelhante a todos eles.

- No subgênero Symphyomyrtus observou-se uma tendência de diminuição das rachaduras com o aumento da altura na árvore.

- No Monocalyptus a tendência foi de aumento das rachaduras na medida em que se aumenta a altura na arvore.

- O Corymbia mostrou um comportamento mais estável, ou seja, as rachaduras permaneceram estáveis com o aumento da altura na árvore.

Encurvamentos

- As espécies que mais se encurvaram logo após o desdobro das toras foram o E. pyrocarpa, $10,03 \mathrm{~mm} ; E$. paniculata, $10,25 \mathrm{~mm} ; E$. cloeziana, $11,77 \mathrm{~mm} ;$ E. microcorys, $12,87 \mathrm{~mm}$. As que menos se encurvaram foram o $E$. maculata, $6,65 \mathrm{~mm} ; E$. toreliana, $6,38 \mathrm{~mm} ; E$. urophylla, 5,76 mm; E.citriodora, 5,33 $\mathrm{mm}$. Tanto as toras de base como as superiores, produziram tábuas que se encurvaram com a mesma intensidade. 
- Existem diferenças significativas entre os subgêneros. 0 Idiogenes difere do Corymbia e do Symphyomyrtus em conjunto. $O$ Monocalyptus é semelhante a todos.

- O E. microcorys difere significativamente do E. urophylla. As demais espécies dentro do subgênero Symphyomyrtus não diferem significativamente entre si.

- No Monocalyptus e no Corymbia não existem diferenças significativas entre as espécies.

- Dentro do gênero Eucalyptus o E. microcorys e o E. cloeziana diferem significativamente do $E$. citriodora. As demais espécies formam um bloco intermediário não diferindo significativamente entre si, ou seja, todas elas apresentam um padrão uniforme de encurvamento.

Rendimento em madeira serrada

- O rendimento médio das toras sem casca em madeira serrada, base tora sem casca para todas as espécies, já descontadas as perdas por rachaduras, foi de $62,77 \%$.

- O E. resinifera, $70,90 \%$; E. propinqua, $68,19 \%$; E. maculata, $66,75 \%$; e o E. saligna, $66,53 \%$; foram as espécies que apresentaram os maiores rendimentos e com menor rendimento o $E$. phaeotricha, 60,66 \%; $E$. pilularis, $60,19 \%$; E. toreliana, $57,30 \%$ e o E. paniculata, $55,61 \%$.

- As toras da base não diferiram significativamente das toras superiores. Ambas apresentaram o mesmo rendimento de madeira serrada,

- Não existem diferenças significativas de rendimento entre os subgêneros.

- No subgênero Symphyomyrtus, em função das perdas por rachaduras, apenas $\circ E$. resinifera difere significativamente do $E$. paniculata no rendimento em madeira serrada.

- No Monocalyptus não existem diferenças significativa de rendimento entre as espécies. 
- No Corymbia existem diferenças significativas de rendimento entre o E. maculata e o E. torelliana.

Correlações entre variáveis

- Existem evidências estatisticas de que o rendimento em madeira serrada correlaciona-se negativamente com o encurvamento e com o indice de rachaduras de extremidade de tábua. Com o aumento do encurvamento em rachadura, diminuem-se os rendimentos.

- Existem evidências de que o rendimento em madeira serrada se correlaciona positivamente com 0 diâmetro e negativamente com a conicidade da tora, mas as correlações não são estatisticamente significativas.

- As rachaduras correlacionam-se positivamente com os encurvamentos, de forma significativa.

- Houve uma tendência negativa entre rachaduras e os diâmetros das toras mas não significativa.

- Existem evidências estatísticas significativas de que os encurvamentos das tábuas apresentaram tendência a correlacionar-se de forma negativa com o diâmetro das toras.

Dureza

- O E. pellita apresentou a maior dureza (Janka), $142 \mathrm{Mpa}$, entre todas as espécie, sugerindo ser a mais indicada em situações que exijam resistência ao desgaste e puncionamento.

- O E. microcorys foi a espécie de menor dureza com $62 \mathrm{Mpa}$ de dureza. Coincidentemente foi a espécie com maior indice de rachaduras e com aparência mais clara entre todas.

Aparência da madeira

- As espécies do subgênero Symphyomyrtus apresentaram cor avermelhada, com uma única exceção para o E. microcorys de cor amarelo grisáceo. 
- No Monocalyptus predominou a cor castanha claro, com uma tendência ao rosa pálido.

- No Corymbia houve predominância da cor castanha clara no alburno e escura no cerne.

- As madeiras de E. citriodora e E. maculata, apresentaram formação de boisas de resina, que prejudicou a sua aparência e seu aproveitamento. O E. torelliana, além de não apresentar esses defeitos, mostrou uma aparência estética apreciável. Essa espécie praticamente não racha e empena muito pouco. Como existe a possibilidade das árvores serem hibridas ( $E$. torelliana $\times$ E. citriodora), conclui-se que a hibridação poderá ser favorável na melhoria da qualidade da madeira.

Comparação das espécies

- As espécies que apresentaram o melhor desempenho ou a menor negatividade foram o E. citriodora, E. torelliana, E. saligna, E. pellita e o $E$. maculata e podem ser consideradas com grande potencial para a produção de madeira serrada.

- As espécies que apresentaram os maiores índices de defeitos foram o E. microcorys, E. pilularis, E. cloeziana e o E. paniculata, podendo ser consideradas, por enquanto, as espécies com maiores restrições e menos recomendadas para a produção de madeira serrada.

- Entre os subgêneros estudados, o Corymbia apresentou os melhores indices para a produção de madeira serrada. 


\section{REFERÊNCIAS BIBLIOGRÁFICAS}

ACOSTA, M. S. Estado de la tecnologia em Usos no Tradicionales de la Madera de Eucalipto em el Mercosur y Outros Paises. In. SEMINÁRIO INTERNACIONAL SOBRE PRODUTOS SÓLIDOS DE MADEIRA DE ALTA TECNOLOGIA. 1., Belo Horizonte, 1998. Anais. Viçosa: SIF,UFV, 1998. p.82-105.

AGUIAR, O.J.R.; JANKOWSKY, I.P., Prevenção e controle das rachaduras de topo em toras de Eucalyptus grand is Hill Ex-Maiden. Piracicaba: ESALQ, 1992. 24p.

AHRENS, S. As necessidades de suprimento de madeira e suas implicações para o manejo de plantações de Pinus no Brasil. In. SEMINÁRIO SOBRE PROCESSAMENTO E UTILIZAÇÃO DE MADEIRAS DE REFLORESTAMENTO, 3., Curitiba, 1994. Anais. Curitiba: ABPM/CNPF, 1994. p.78-84.

ALFONSO, V.A. Caracterização anatômica do lenho e da casca das principais espécies de Eucalyptus L'Herit. Cultivadas no Brasil. São Paulo, 1987. 188p. Tese (Doutorado)- Instituto de Biocências, Universidade de São Paulo.

ALVES, M.C. SAS - estatística básica. Versão 3.1.Piracicaba: ESALQ,CIAGRI, 1994. $52 \mathrm{p}$.

ANDRADE, E.N., O eucalipto. 2.ed. Jundiaí: Companhia Paulista de Estradas de Ferro, 1961. 664p.

ARCHER, R.R. Growth stress and strain in trees. Berlin: Springer Verlag, 1987. 240p.

ASSIS, T.F. Aspectos do melhoramento de Eucalyptus para obtenção de produtos sólidos da madeira. In: WORKSHOP SOBRE TÉCNICAS DE ABATE, PROCESSAMENTO E UTILIZAÇÃO DA MADEIRA DE EUCALIPTO, Viçosa, 1999. Anais. Viçosa: UFV,DEF,IEF, 1999. p.61-62.

BARISKA, M. A method for predicting timber quality in Eucayptus. In: MANAGEMENT OF EUCALYPTUS GRANDIS SOUTH AFRICA. Stellenbosch, 1990. Proceedings. Stellenbosch: Southem Afrcan Institute of Forestry, 1990. p.215228. 
BARNACLE, J.E. Rapid effect of drying on development of heart cracks. Australian Forestry, v.35, n.4, p.251-257, 1971

BERNARDO, B. Curso prático de bioestatística. 4.ed. Ribeirão Preto: Sociedade Brasileira de Genética, 1996. 254p.

BERENGUT, G.; PONCE, R.H.; FREITAS, A.R. Ensaio de desdobro em Eucalyptus saligna Smith. Silvicultura, v.8, p.81-98, 1973.

BORTOLETTO, G.J. Indicações para a utilização da madeira de seis espécies e variedades de Pinus na construção civil. São Carlos, 1993, 119p. Dissertação (Mestrado) - Escola de Engenharia de São Carlo, Universidade de São Paulo.

BOYD, J.D. Tree growth stresses- Part v: evidence of na origin in differentiation and lignification. Wood Science and Technology, v.6, p.251-262, 1972.

BRASIL. Ministério da Agricultura. Comissão de solos. Levantamento dos solos do Estado de São Paulo. São Paulo, 1960. 634p.

BUSNARDO, C.A.; GONZAGA, J.V.; MENOCHELLI, S.; BENITES, E.P.; DIAS, C.; FOELKEL, C. E. Umidade ao abate da madeira e da casca de Eucalyptus grandis. Rio Grande. Cia. De Celulose do Sul - Riocell. Silvicultura. v. 8, n.28, p.749-753. 1983.

CAMPOS, C.C.J.; LEITE, G.H.; SOUZA, N.R.; VITAL, R.B. Relações entre espaçamento, volume e peso de madeira em plantações de eucalipto. Revista Árvore, v.14, n.2, p.119-133, 1990.

CHAFE, S. C. Growth stress in trees. Australian Forest Research, v.9, p.203-223, 1979.

CHAFE, S.C. Variations in longitudinal growth stress, basic density and modulus of elasticity with height in the tree. Australian Forest Research, v.11, n.1, p.79-82, 1981.

CHAFE, S.C. Variation in longitudinal growth stress with height in trees of Eucalyptus nitens, Maiden. Australian Forest Research, v. 15, n.1, p.51-55, 1985.

CORPORACIÓN DE FOMENTO DE LA PRODUCCIÓN. INSTITUTO FORESTAL. Principios de organización y operación del aserradero. Concepción, 1989. 217p.

COSTA NETO, P.L.O. Estatistica. 17.ed. São Paulo: Edgard Blücher, 1999. 264p.

CRESPO, E. A. Tensões de Crescimento e suas conseqüência, controláveis e não controláveis, no desdobro e secagem do Eucalyptus grandis e Eucalyptus saligna. 
Piracicaba, 2000. 119 p. Dissertação (Mestrado) - Escola Superior de Agricultura Luiz de Queiroz, Universidade de São Paulo.

CURRO, P.; CAVIDINI, R. Preliminary observations on growth stress in Eucalyptus. In: CONFERENCIA MUNDIAL DO EUCALPTO, 2., São Paulo, 1961. Relatórios e documentos. São Paulo, 1961. p.1123-1133.

DEL MENEZZI, C.H.S. Utilização de um método combinado de desdobro e secagem para a produção de madeira serrada de Eucalyptus grandis Hill Ex Maiden e de E. Cloeziana F. Muel. Piracicaba, 1998. Dissertação (Mestrado) - Escola Superior de Agricultura Luiz de Queiroz, Universidade de São Paulo.

DOE, P. E.; LEE, M. Drying backsawn timber from tasmanian regrowth Eucalypt. Tasmania: University of Tasmania, Forests\&Forest Industry Council of Tasmania. 2000. $7 \mathrm{p}$.

DONNELL,Y,R., SUCHET,V.; Oportunidades de expansão para o setor madeireiro. Revista da Madeira. v.6, n.32, p.4-6, 1996.

DURLO, M. A.; MARCHIORI, J. N. C. Retratibilidade da madeira. Centra de Pesquisas Florestais - CEPEF. Tecnologia da madeira. Série Técnica UFSM, n. 10.1992

FAO. El eucalipto em la repoblación forestal. Roma, 1981. 723 p.

FERNANDES, P.S. Variação da Densidade da Madeira e Suas relações com as Tensões de Crescimento em progênies de Eucalyptus urophylla. S.T. Blake. Piracicaba, 1982. Dissertação (Mestrado) - Escola Superior de Agricultura Luiz de Queiroz, Universidade de São Paulo.

FERNANDEZ, P.S.; FLORSHEIM, S.M.B.; ROCHA, F.T.; MONTAGNA, R.G.; Tensões de crescimento em procedências de Eucalyptus grandis Hill Ex Maiden e suas relações com as características das fibras e densidade básica. Revista do Instituto Florestal, v.1, n.1, p.215-234. 1989.

FERRAND, J.C. Growth stresses and silviculture of Eucalypts. Australian Forest Research, v.13, n.1. p.75-81. 1983.

FERREIRA, M., Escolha de espécies de Eucalyptus. Circular Técnica IPEF, n.47, maio.1979. 30p.

FERREIRA, M.; SIMÕES, J.W. Formação de população base de Eucalyptus pilularis Smith, visando produção de madeira para usos múltiplos. IPEF, n.47, p.1-21, mai. 1994. 
FISHWICK, W.R. Estudos de espaçamentos e desbastes em plantações brasileiras. Brasil Florestal, v.7, n.26, p.13-23, 1976.

FLEISCHER, H.O. The impact of utilization research on the complete use of the forest. Wood Science and Technology, v.5, p.247-254, 1971.

FRANCO, N., Agrupamento das propriedades físicas e mecânicas da madeira. São Paulo: IPT, 1995. 46p.

FREITAS, A.R.; NETO, O.B. Avanços tecnológicos no processamento e uso de produtos florestais: Produção de madeira serrada para Eucalipto. In: CONGRESSO FLORESTAL PAN-AMERICANO, 1., CONGRESSO FLORESTAL BRASILEIRO, 7., Curitiba, 1993. Anais. São Paulo: SBS, 1993. v.3. p.293-295

GAIOTTO, M.R. Avaliação da madeira de Eucalyptus saligna e Eucalyptus urophylla para produção de lâminas. Piracicaba, 1993. 119p. Dissertação (Mestrado) - Escola Superior de Agricultura Luiz de Queiroz, Universidade de São Paulo.

GALVÃO, A.P.M. Aspectos da utilização da madeira de eucalipto no Brasil - Seu aproveitamento em serraria. Boletim Informativo IPEF, v.4, n. 12, p. 1-23, Jul. 1976.

GALVÃO, A.P.M.; JANKOWSKY, I.P. Secagem racional da madeira. São Paulo: Nobel, 1985. $111 \mathrm{p}$.

GARCIA, J.N. Processamento mecânico de Pinus e Eucalipto. Piracicaba: ESALQ, LCF, 1988. 20p.

GARCIA, J.N. Técnicas de desdobro e Eucalipto. In: SEMINÁRIO INTERNACIONAL DE UTILIZAÇÃO DE EUCALIPTO PARA SERRARIA, São Paulo, 1995. Anais. Piracicaba: IPEF, 1995. p.59-67.

GARCIA, J.N. An alternative sawmill plant to improve Eucalyptus lumber quality. In: INTERNATIONAL WOOD MACHINING SEMINAR, 13., Vancouver, 1997. Procedings. Vancouver: University of British Columbia, 1997. p.865-874.

GOES, E. Os Eucalyptus: ecologia, cultura, produções e rentabilidade. Lisboa: Ed. Peres. Artes Gráficas, 1977. 367p.

GOMES, F. P. Curso de estatística experimental. Piracicaba: ESALQ, 1963. 384p.

GROSSER, D. Defeitos da madeira: palestra proferida no curso de Eng. Florestal. Curitiba: UFPr, 1979. 6 lp. (Série Técnica FUPEF). 
HASLETT, A.N. A guide to handling and grade-sawing plantation-grown eucalyptus. FRI Bulletin, v. 142, p. 1-72, 1988.

HAYGREEN, J.C.; BOWYER J.L. Forest products and wood science. 2.ed. Ames: Iowa State University Press, 1994. 500p.

HELLMEISTER, J.C. Determinação das características físicas da madeira. São Carlos, 1973. 122p. Tese (Doutorado) - Escola de Engenharia de São Carlos, Universidade de São Paulo.

HELLMEISTER, J.C. Madeiras de eucalipto e suas propriedades. Sociedade Brasileira de Silvicultura. Sivicultura, n. 44, p.9-11, jul./ago. 1992.

HILLIS, W.E. Some changes associated with the formation of heartwood and exudates. In: IUFRO MEETING DIVISION, Pretoria, 1973, Procedings. v.3, p.958-964.

HILLIS, W.E.; BROWN, A.G. Eucalypts for wood production. Melbourne: CSIRO, 1978.

JACOBS, J.R. The growth stresses of woody stems. Camberra: Commonwealth Forestry Bureau, 1945. 67p. (Bulletin, 28.)

JANKOWSKY, I.P. Equipamentos e processos para secagem de madeiras. In: SEMINÁRIO INTERNACIONAL DE UTILIZAÇÃO DA MADEIRA DE EUCALIPTO PARA A SERRARIA, São Paulo, 1995. Anais. Piracicaba: IPEF, 1995. p. 109-118.

JARA, E.R.P.; MIRANDA, M.J.A.C.; HUMPHREYS, R.D. Influência do tratamento térmico na redução das tensões internas de crescimento em toras de Eucalyptus grandis. In: CONFERÊNCIA IUFRO SOBRE SILVICULTURA E MELHORAMENTO DE EUCALIPTOS, Salvador, 1997. Proceedings. Colombo: EMBRAPA, 1997. p.276-280.

KIKUTI, P.; SATSUKI,N.F.; CALORI,J.V. Produção de madeiras de reflorestamento de alta qualidade. In: SEMINÁRIO SOBRE PROCESSAMENTO E UTILIZAÇÃO DE MADEIRAS DE REFLORESTAMENTO. Curitiba, 1996. Anais. Curitiba: ABPSM/SBS, 1996. p.53-58.

$\mathrm{KOCH}, \mathrm{C} . \mathrm{B} .$, Bark volume of yellow-poplar, red black and soarlet oak, and red maple in northern west Virginia. Morgantown: Agriculture Experiment Station, 1971.20p.

KOLLMANN, F.F.P., COTÉ, W.A. Principles of wood science and technology. New York: Springer-Verlag, 1968. v.1, 528p. 
KUBLER, H. Growth Stress in Trees and Related Wood Properties. Forest Products Abstracts, Madison, Wisconsin, v.10, n.3, p.61-119, 1987.

LEITE, H.L. Conversão de troncos em multiprodutos da madeira utilizando programação dinâmica. Viçosa, 1994. 230p. Tese (Doutorado) - Universidade Federal de Viçosa.

LIMA, I.L. Variação de propriedades indicativas da tensão de crescimento em função da posição na árvore e da intensidade de desbaste. Piracicaba, 2000. Dissertação (Mestrado) - Escola Superior de Agricultura Luiz de Queiroz, Universidade de São Paulo.

LIMA, J.T. Influência do teor de umidade nas propriedades mecânicas da madeira de Eucalyptus saligna. Viçosa, 1983. Dissertação (Mestrado) - Universidade Federal de Viçosa.

LISBOA, C.D.J. Estudo das tensões de crescimento em toras de Eucalyptus grandis Hill. Ex Maiden. Revista Floresta, Curitiba, v.23. n.2. p.82-83, jun/dez. 1995

LOEHNERTZ, S.P. Hardwood sawing tehnology in five tropical countries. Forest Products Journal, v.46, n.2, p.51-55, Fev. 1996.

LOPES, G. A. Qualidade da madeira de Eucalyptus saligna Smith, de Itatinga, associada aos padrões de casca apresentados pela população. Piracicaba, 2000. Dissertação (Mestrado) - Escola Superior de Agricultura Luiz de Queiroz, Universidade de São Paulo.

MALAN, F.S. The control of end splitting in sawlogs: a short literature review. South African Forestry Journal, v. 109, p.14-18, jun. 1979.

MALAN, F. S. Studies on the phenotypic variation in growth stress intensity and its association with tree and wood properties of South African grown Eucalypts grandis (Hill ex Maiden). Stellenbosch, 1984. 258p. Thesis (Ph.D.) - University of Stellenbosch.

MALAN, F.S. Eucalyptus improvement for lumber production. SEMINÁRIO INTERNACIONAL DE UTILIZAÇÃO DA MADEIRA DE EUCALIPTO PARA SERRARIA, São Paulo, 1995. Anais. Piracicaba: IPEF, 1995. p.1-19.

MALAN, F.S. Relationship between growth stress and some tree characteristics in south African grown Eucalyptus grandis. South African Forestry Journal, v.144, p.43-46. Mar. 1998. 
MANGERI, H.R.; DIMITRI, M.J. Los Eucalyptus en la silvicultura. Buenos Aires: Editora ACME, 1958. 213p.

MARDER, M. Cracks of doom. New Scientist, v.2097, p.32-35, 1997.

MELLO, G.R. Processamento mecânico da madeira. Piracicaba: ESALQ, 1978. 88p.

MIGLIORINI, A.J. Variação de Densidade Básica da Madeira de Eucalyptus grandis Hill ex. Maiden em função de diferentes níveis de produtividade da Floresta. Piracicaba. 1986. 80p. Dissertação (Mestrado) - Escola Superior de Agricultura Luiz de Queiroz, Universidade de São Paulo.

MIRANDA, M.J.A.C. Estudo da influência do espaçamento de plantio de Eucalyptus Smith no rendimento em madeira serrada, nas condições verde e seca. Piracicaba, 1997. 162p. Dissertação (Mestrado) - Escola Superior de Agricultura Luiz de Queiroz, Universidade de São Paulo.

MIROW, A. Novo conceito de madeira da Aracruz. Revista Silvicultura, v. n.79 P. 2023. Jul./Set. 1999.

MONTAGNA, R.G.; PONCE,R.H.; FERNANDES, P.S.; RIBAS,C. Desdobro de Eucalyptus grandis Hill ex Maiden visando a diminuir o efeito das tensões de crescimento. Revista do Instituto florestal, v.3, n.2. p.181-190. 1991.

NAHUS, M.A.R.; MIRANDA, M.J.A C; FRANCO, N. Inovação na área de utilização da madeira de eucalipto: A fabricação de móveis. In. WORKSHOP SOBRE TÉCNICAS DE ABATE, PROCESSAMENTO E UTILIZAÇÃO DA MADEIRA DE EUCALIPTO, Viçosa, 1999. Anais. Viçosa: UFV,DEF,SIF,IEF, 1999. p.28-33

NICHOLSON, J.E., A rapid method for estimating longitudinal growth stresses in logs, Wood Science and Technology, v.5, p.40-48, 1971

NICHOLSON, J.E.; HILLIS, W.E.; DITCHBURNE, N.; Some tree growth - wood property relationship of Eucalypts. Canadian Journal of Forest Research, v.5, p.424-432, 1975.

NICOLIELO, N. Aspectos gerais sobre manejo florestal em florestas homogêneas de Pinus sp. São Paulo: SBS, 1987.

NUNES, J.R.S. Análise do volume e da percentagem de casca em povoamentos de Eucaliptos de origem hibrida, segundo a idade, local, espécie e método de regeneração. Viçosa, 1881. 120p. Dissertação (M.S.) - Universidade Federal de Viçosa. 
OBINO, C.R.; MENEZES, L.F. Manejo de florestas para serraria nas empresas nacionais: algumas experiências de manejo de eucalipto para serraria. In: SEMINÁRIO INTERNACIONAL DE UTILIZAÇÃO DE MADEIRA DE EUCALIPTO PARA SERRARIA, São Paulo, 1995. Anais. Piracicaba: IPEF, 1995. p. 140-146.

OLIVEIRA, J.T.S. Problemas e oportunidades com utilização da madeira de eucalipto. In: WORKSHOP SOBRE: TÉCNICAS DE ABATE, PROCESSAMENTO E UTILIZAÇÃO DA MADERA DE EUCALIPTO, Viçosa, 1999. Anais. Viçosa, UFV,DEF,SIF,IEF. 1999. p.39-52

OLIVEIRA, J.T.S., Caracterização da madeira de Eucalipto para a construção civil. São Paulo, 1997. 429p. Tese (Doutorado) - Escola Politécnica, Universidade de são Paulo.

OLIVEIRA, L.C.S. Empenamento da madeira: causas e métodos de prevenção. In: COMPÊNDIO DA INFORMAÇÃO TÉCNICA PARA A INDÚSTRIA MOBILIÁRIA. Bento Gonçalves: Alternativo Editorial, 1992. p.175-176.

OKUYAMA, T. Assessment Growth stresses and peripheral strain in standing trees. In: IUFRO CONFERENCE ON SILVICULTURE AN IMPROVEMENT OF EUCALYPTS, Salvador, 1997. Anais. Colombo: EMBRAPA,CNPF, 1997. v.3, p.114.

OTTE, G. Experiências e controle da qualidade da madeira de eucalipto e oportunidades no mercado internacional e nacional. In. MADEIRA DE EUCALIPTO: TENDÊNCIA E USOS. SEMINÁRIO MADEIRA DE EUCALIPTO. CENTRO DE CIÊNCIAS FLOREST AIS, Curitiba, 2001. Anais. Curitiba: Ed. 2001.

PANSHIN, A.J., De ZEEUW, C. Textbook of wood technology. 4.ed. New York: McGraw-Hill, 1970. 722 p.

PASZTOR, Y.P.C. Teste de procedências de Eucalyptus pilularis na região de MogiGuaçu. Piracicaba. 1972. 61p. Tese (Doutorado) - Escola Superior de Agricultura Luiz de Queiroz, Universidade de São Paulo.

PFEIL, W. Estruturas de madeiras. 4.ed. Rio de Janeiro: Livros Técnicos e Científicos, 1985, 365p.

PONCE, R.H. Novas tecnologias de desdobro e beneficiamento de madeira: A busca da competitividade. In: CONGRESSO FLORESTAL PAN-AMERICANO, 7. CONGRESSO FLORESTAL BRASILEIRO, 7., Curitiba, 1993. Anais. São Paulo: SBS,SBEF, 1993. p.310-314. 
PONCE, R.H. Perspectivas do eucalipto na substituição de madeiras nativas. In: SEMADER. SEMINÁRIO SOBRE PROCESSAMENTO E UTILIZAÇÃO DE MADEIRAS DE REFLORESTAMENTO, 3., Curitiba, 1994. Anais. Curitiba: Ed. IPEF. p.42-46.

PONCE, R.H. Madeira serrada de eucalipto: desafio e perspectivas. In. IUFRO CONFERENCE ON SILVICULTURE AND IMPROVEMENT OF EUCALYPTS. Salvador, 1997. Proceedings, Colombo: EMBRAPA, 1997. v. 3, p.50-58.

PRYOR L.D.; JOHNSON, L. A. S. A classificação of the Eucalypts. Camberra: The Australian National Universit, 1971, 112p.

RAMOS, I. África do Sul horizonte florestal no Brasil. o eucalipto, madeira de serraria na África do Sul. São Paulo: Ed. Joruês, 1973. 81 p.

REFLORESTAMENTO é alternativa para oferta de madeira. Revista da Madeira, v. 1 n.1, p. 4-5, 1992.

ROCHA, J.S. A segurança de estruturas de madeira determinada a partir da variabilidade da densidade básica e de propriedades mecânicas de madeiras amazônicas. Piracicaba, 1994. 132p. Dissertação (Mestrado) - Escola Superior de Agricultura Luiz de Queiroz, Universidade de São Paulo.

ROCHA, M. P. Desdobro primário da madeira. FUPEF, Séria Didática, n.2, p.1-61, 1999.

SANTINI, E. J. Biodeterioração e preservação da madeira. Santa Maria: UFSM,CEPEF,FATEC, 1988. 125p.

SAYAGUÉS, L. La productividad y el rendimiento en los aserraderos. Revista de la Sociedad de Productores Forestales. v.3, n.13, p.39-41. nov. 1999.

SCHACHT, L., Variação de caracteres e suas implicações para o melhoramento genético da madeira serrada em Eucalyptus urophylla. Piracicaba, 1998. 58p. Dissertação (Mestrado) - Escola Superior de Agricultura Luiz de Queiroz, Universidade de São Paulo

SHARMA, S.N.; PANDEY, C.N.; KANNOJ, H.C. Sawing and seasoning technique for Eucalyptus tereticornis. Journal Timber Development of India, v.34, n.4, p.5-12, 1988. 
SIMÕES, J.W.; SPINA, F. Produção de madeiras em florestas energéticas sob diferentes práticas silviculturais. In: SIMPÓSIO DE ENERGIA DA BIOMASSA FLORESTA, São Paulo, 1983. Anais. Piracicaba: IPEF, 1983. p.1-36.

SIMÕES, J. W.; FERREIRA, M. Resultado do desbaste em 14 espécies de Eucalipto para produção de madeira e sementes. In: IUFRO CONFERENCE ON SILVICULTURE AND IMPROVEMENT OF EUCALYPT, Salvador, 1997. Proceedings. Colombo: EMBRAPA, 1997. p. 343-348.

SCOLFORO, J.R.; FILHO, A. F. Mensuração florestal - Módulo 2: Volumetria Lavras: ESAL, 1995. 126p.

SCHENEIDER, P.R.; SILVA, J.A. Teste de equações para predizer a espessura da casca e fator K para Acácia negra (Acácia mearnsii de Wild). Revista Florestal, v.10, n.2, p.5-11, Dez.1979.

SMITH, D. M.; LARSON, B. C.; KELTY, M.J; ASHTON, P.M.S. The practice of silviculture: applied forest ecology. New York, John Wiley, 1996. 537p.

SOUNIS, E. Bioestatistica: princípios fundamentais, metodologia, estatística aplicada às ciências biológicas. 2. ed. São Paulo, Mc Graw-Hill do Brasil, 1979. 230p.

STUMPP, E. Estudos Tecnológicos Unisinos. Engenharia. Revista do Centro de Ciências Tecnológicas da Unisinos. p. 1-75, 1997.

SUDAM/IPT. Grupamento de espécies tropicais da Amazônia por similaridade de características básicas e por utilização. Belém: SUDAM,IPT, 1981. 237p.

TEJADA, A.; OKUYAMA, T.; HIROYUKI, Y; MASATO, Y. Reduction of Growth Stress in Logs by Direct Heat Treatment: Assessment of a Commercial-Scale Operation. Forest Products Journal. v.47, n.9, p. 86-92. 1997

TOMAZELLO FILHO, M. Formação e anatomia da madeira., exercícios práticos., material didático de Aulas práticas. Piracicaba: ESALQ, 1998. 75p.

TOMAZELLO FILHO, M. Formação e caracterização da estrutura anatômica da madeira de Eucalyptus. Piracicaba: ESALQ, 1994. 11 p.

VIGNOTE, S.; MOLINERO, I.; GERARD, J.; DIEZ, M.R. Estudio de Las Tensiones de Cresimiento Del Eucalyptus globulus labill En Galicia y Su Relacion con Las Caracteristicas De la Estacion y Morfológicas Del próprio Arbol. Investigacion Agrário: Sistemas e Recursos Forestales, v.5, p. 154-165. n.1, 1996. 
WILSON, P.J. Splitting studies on logs of Eucalyptus macarthurii, E. elata, and E. radiata. In: INSTITUTE FOR COMMERCIAL FORESTRY RESEARCH. Annual report. Pietermaritzburg, 1985. p.135-142.

WALKER, J.C.F. Saw milling. In: WALKER, J.C.F. Primary wood processing: principles and practices. London: Chapman \& Hall, 1993. p. 196-246.

WAUGH, G. Reducing Growth Stresses in standing Trees. Division of Building Research, CSIRO. Australian Forest Research, 1977, p. 215-218.

WAUGH, G. Sawing of Young, Fast-Grown Eucalypts. SEMINÁRIO INTERNACIONAL SOBRE PRODUTOS SÓLIDOS DE MADEIRA DE ALTA TECNOLOGIA,1., Viçosa, 1998. Anais. Viçosa: UFV, 1998. p.69-81.

VAN WYK, J.L. Hardwood saw milling can have a bright future in South Africa. South African Forest Journal, v. 107, p.47-53. 1978.

VERMAAS, H. F. Primary processing of eucalypts and factors affecting it. Southern African Forestry Journal, v.187, p. 37-44. Mar.2000.

YANG, J.L.; WAUGH, G. Potential of plantation-grown eucalypts for structural sawn products. I.Eucalyptus globulus labil.ssp.globules. Australian Forestry, v.59, n.2, p.90-98. I

YAO, J. Relationships between height and growth stress eithin and among white ash, water oak. and shagbark hickory. Wood Science., v.2, n.4. p.146-251, Abr.1979.

ZENID, G.J. Classificação de madeira serrada de eucalipto. Proposta ABPM/IPT. In. SEMINÁRIO SOBRE PROCESSAMENTO E UTILIZAÇÃO DE MADEIRAS PARA REFLORESTAMENTO, Curitiba, 1996. Anais. Curitiba: ABPM. 1996. p. 9196. 